\title{
The Manuscripts Oskar Rescher Sold to the Berlin State Library Between 1913-1936
}

\section{Osman Reșer'in 1913-1936 Yılları Arasında Berlin Devlet Kütüphanesi’ne Sattığı Yazmalar}

\author{
Güler Doğan Averbek ${ }^{1}$ (D)
}

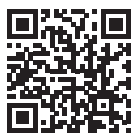

*This study received financial support from the Prussian Cultural Heritage Foundation with the title "Reconstruction of Oskar Rescher's Life and Works as an Orientalist:" I am grateful to the officials at the institution. I would also sincerely like to thank the Director of the Oriental Department of the Berlin State Library, Christoph Rauch, who provided the environment I felt necessary and allowed me access to the manuscripts and library archive and my dear to the manuscripts and library archive, and my dear friend Dr. Thoralf Hanstein, my supporter behind the study. I would like to express my gratitude to the Rectorate of Istanbul University and Istanbul Univer for ISAMER Director Prof.Dr. Ahmet Hamdi Furat for the institutional support they offered my support I received during my time in Berlin.

*Bu çalışma, "Reconstruction of Oskar Rescher's Life and Works as an Orientalist: A Life between Germany and Istanbul" adıyla Stiftung Preußischer Kulturbesitz'in maddi desteğini almıştır, kurum yetkililerine müteşekkirim. Ayrıca ihtiyaç duyduğum ortamı temin eden ve kütüphane kayıtları ile yazmalara erişim imkânı tanıyan Berlin Devlet Kütüphanesi Şarkiyat Bölümü Müdürü Christoph Rauch'a ve çalışmanın ardındaki maddi-manevi destekçim, kıymetli dostum Dr. Thoralf Hanstein'a içten teşekkür ederim. Çalıssmaya sunduklar kurumsal destek sebebíyle Istanbul Üniversitesi Rektörlüğüne, İstanbul Úniversitesi ISAMER Müdürü Prof.Dr. Ahmet Hamdi Furat'a, Berlin'de bulunduğum süre zarfinda desteklerini gördüğüm Sinan Illhan'a, Mehmet Çelebi'ye şükranlarımı sunarım.

${ }^{1}$ Corresponding author/Sorumlu yazar: Güler Doğan Averbek (Doç. Dr.),

Marmara University, Faculty of Arts and Sciences, Department of Turkish Language and Literature, Istanbul, Turkey

E-mail: guler.dogan@marmara.edu.tr

ORCID: 0000-0002-8938-1115

Submitted/Başvuru: 27.06.202

Revision Requested/Revizyon Talebi: 16.07.2021

Last Revision Received/Son Revizyon: 22.07.2021

Accepted/Kabul: 26.07.2021

Citation/Atıf: Doğan Averbek Güler Th Manuscripts Oskar Rescher Sold to the Berlin State Library Between 1913-1936 islam Tetkikleri Dergisi-Journal of Islamic Review 11/2, (Eylül 2021): $477-568$

https://doi.org/10.26650/iuitd.2021.958080

\begin{abstract}
Born in Stuttgart in 1883, Oskar Rescher was a prolific Orientalist of the 20th century. He spent his life between Germany and Istanbul from 1909 to 1925 and settled down in Turkey in 1925. He studied many manuscripts found in private collections, libraries, and second-hand bookstores and sold thousands of manuscripts to various libraries and second-hand bookstores in Europe and America. Although the details have not been uncovered, Rescher's manuscript sales are still being voiced in certain circles; however, his manuscript trade has not been the subject of any study until ours.

This article constitutes the second phase of a series of studies. The first article, titled "Oskar Rescher - Biographical Finds around Manuscripts, Books, and Libraries" and the product of a collaborative effort, focused on Rescher's life and his trade activities with the Berlin State Library. The current study draws attention to two issues. The first involves the 1,722 volumes sold to the Berlin State Library after Rescher's death. According to our determinations, these manuscripts did not belong to Rescher. The second issue involves the manuscripts Rescher sold to the Berlin State Library between 1913-1936. This article provides a detailed list of these manuscripts after mentioning the sales process. Thus, this study intends to direct attention to the 1,192 manuscripts one Orientalist scholar had personally selected, studied, and sold.

The title, author name, and language are specified for each work on the list that has been organized with respect to the date and identification order by which the manuscripts were recorded in the acquisition journal at the library; this includes majmuas, and the manuscripts' shelf numbers are also given. The list additionally includes the catalogue reference where detailed information about the related manuscript can be found; manuscripts not yet catalogued have been also noted.
\end{abstract}

Keywords: Osman Reşer, manuscript trade, Berlin State Library, Staatsbibliothek zu Berlin, Islamic manuscripts

\section{Öz}

1883'te Stuttgart'ta dünyaya gelen Osman Reşer (Oskar Rescher), 20. asrın üretken şarkiyatçılarındandır. 1909-1925 yıllarında Almanya-İstanbul arasında bir hayat sürmüş, 1925'te Türkiye'ye yerleşmiştir. Türkiye'de özel 
koleksiyonlarda, kütüphanelerde ve sahaflarda bulunan pek çok yazmayı incelemiş, binlerce yazmayı Avrupa ve Amerika'daki muhtelif kütüphanelere ve sahaflara satmıştır. Detayları söylenmemekle birlikte Reşer'in yazma satışı bugüne kadar belli muhitlerde dillendirilegelmiş; fakat -bizim çalışmalarımıza kadar- onun yazma ticareti herhangi bir çalışmaya konu olmamıştır.

Bu makale bir dizi çalışmanın ikinci halkasını teşkil etmektedir. Müşterek bir çalışmanın ürünü olan "Oskar Rescher - Biographical Finds around Manuscripts, Books and Libraries" başııkı ilk yazıda Reşer'in hayatına ve Berlin Devlet Kütüphanesi ile arasındaki ticari faaliyete odaklanılmıştır. Bu çalışmada ise iki hususa dikkat çekilmektedir. İlki Reşer'in vefatından sonra Berlin Devlet Kütüphanesi'ne satılan 1722 cilt yazmadır. Tespitimize göre söz konusu yazmalar Reşer'e ait değildir. İkinci husus ise bizzat Reşer'in 1913-1936 yılları arasında Berlin Devlet Kütüphanesi'ne sattığı yazmalardır. Bu yazıda satış sürecine değinildikten sonra yazmaların detaylı bir listesi verilmiştir. Dolayısıyla bu çalışma ilgiyi, elsine-i selâseye vâkıf bir şarkiyat âliminin bizzat seçerek ve etüt ederek sattığı 1192 yazmaya yönlendirme amacındadır.

Yazmaların kütüphane sağlama defterine kaydedildikleri tarihe ve künye sırasına göre tertip edilen listede mecmualar dâhil her bir metnin eser adı, müellif adı ve dili belirtilmiş, yazmaların raf numaraları verilmiştir. Listede ayrıca ilgili yazma hakkında detaylı bilginin bulunabileceği katalog gösterilmiş; henüz kataloglanmayan yazmalar belirtilmiştir.

Anahtar Kelimeler: Oskar Rescher, yazma ticareti, Berlin Devlet Kütüphanesi, Staatsbibliothek zu Berlin, İslam yazmaları

\section{GENIŞLETILMIŞ ÖZET ${ }^{1}$}

Avrupa'dan Amerika'ya koleksiyonlarında İslam yazmaları bulunduran pek çok kütüphane, istatistiki verilerindeki büyüklüğü kısmen Osman Reşer'e (Oskar Rescher, 1883-1972) borçludur. O, pek çok ülkeye sattığ 1 yazmalarla 20. yüzyılın muhtemelen en aktif İslam yazması taciri unvanını hak eden küresel bir yazma tüccarı, simsarıdır. Bugün British Library (o zaman British Museum), Cambridge Üniversitesi Kütüphanesi, Bodleian Kütüphanesi, Uppsala Üniversitesi Kütüphanesi, Basel Üniversitesi Kütüphanesi, Yale Üniversitesi Beinecke Nadir Eser ve Yazma Kütüphanesi, California Üniversitesi Kütüphaneleri, Vatikan Kütüphanesi ve Avusturya Millî Kütüphanesi'nde Reşer'den satın alınmış İslam yazmaları mevcuttur.

Reşer'in sunduğu uzmanlık ve ticari faaliyet ile Türkçe, Arapça ve Farsça yüzlerce yazma Münih, Hamburg, Leipzig, Göttingen, Tübingen, Halle'deki kütüphanelerin koleksiyonlarına dâhil olmuştur. Berlin Devlet Kütüphanesi’nin ise 20. yüzyılda satın aldığı yazmaların önemli bir kısmı Reşer yoluyla temin edilmiştir. Bunlar Reşer'in 1913-1936 arasında peyderpey kütüphaneye sattığı yazmalardır.

Öte yandan Berlin Devlet Kütüphanesi'ne Reşer'in vefatından sonra onun şahsi koleksiyonu

1 Bu bölümde yer alan bilgiler kısmen Reşer hakkındaki kapsamlı çalışmamızdan ihtisaren alınmıştır (bkz. Güler Doğan Averbek - Thoralf Hanstein, "Oskar Rescher - Biographical Finds around Manuscripts, Books and Libraries," Sammler - Bibliothekare - Forscher: Beiträge zur Geschichte der Orientalischen Sammlungen an der Staatsbibliothek zu Berlin, ed. Sabine Mangold-Will, Christoph Rauch, Siegfried Schmitt (Frankfurt/Main: Vittorio Klostermann Verlag, 2021, 387-449)). Böylece bu çalışmanın giriş bölümüne sunduğu katkı ve verdiği müsaade için Dr. Hanstein'a müteşekkirim. 
olduğu iddiasıyla satılan 1722 cilt yazmanın ${ }^{2}$-incelemelerimize göre- onunla ilgisi yoktur. ${ }^{3}$ Bu yazmalar Ayla König (1918?-1993) tarafindan 1974'te kütüphaneye satılmıştır.

Bu çalışmada Reşer'in hayat hikâyesine kısaca temas edildikten sonra onun 1913-1936 yılları arasında Berlin Devlet Kütüphanesi'ne sattığı yazmalarla alakalı mülahazalara yer verilmiş ve yazmaların detaylı bir listesi sunulmuştur. Bu liste, kütüphanenin sağlama defteri ile demirbaş defterleri incelenerek, matbu ve dijital kataloglar taranarak ve Reşer yoluyla temin edilen bütün yazmalar görülerek oluşturulmuştur. Bilgimize göre bu çalışma öncesinde kütüphanede veya başka herhangi bir yerde söz konusu yazmalarla alakalı bir liste/envanter çalışması yapılmış değildir.

Oskar Emil Rescher, 1 Ekim 1883'te Stuttgart'ta, Adolf ve Leopoldina çiftinin tek çocuğu olarak dünyaya geldi. 1937'de Türk vatandaşı olduktan sonra Osman Yaşar Reşer adını aldı. 1908'de Friedrich-Wilhelms-Universität zu Berlin (bugün Humboldt-Universität zu Berlin), Filoloji Fakültesi, Şark Dilleri Bölümü’nden mezun oldu. 1909'da doktor unvanını aldı.

1909'dan itibaren İstanbul'a ziyaretler gerçekleştiren Reşer, bu seyahatleri esnasında İstanbul ve Bursa'daki yazma eserleri inceledi, bu incelemelerin neticelerini yayınladı. Bu sıralarda pek çok dergide makale yayınlamaya, özellikle İstanbul'da hem yazmalardan hem İsmail Saib Efendi'den (1873-1940) beslenerek hazırladığı kitapları neşretmeye başladı. 1914'te askere çağrıldı ve I. Dünya Savaşı'nın bitimine kadar görev yaptı. 1919'da doçent, 1925 'te profesör oldu.

Reşer, ancak 1925 senesinde yani 42 yaşındayken İstanbul'a dönebildi; ömrünün kalan kısmını Türk topraklarında geçirdi. Balkan Savaşları'ndan önce İstanbul'a gelen Reşer'in bu seyahati, ileride İstanbul'u yurt edinmesine yol açan hadiseler zincirinin başlangıcı oldu. Doğu dilleri alanında doktor unvanını alan Reşer, sahasında çok iyi yetişmenin yollarını araştırdı ve İstanbul'a yerleşmeyi seçti. Onun İstanbul'a yerleşmesinin sebepleri irdelenirken bu şehirde karşılaştığı ortam ve kurduğu ilişkiler kadar Osmanlı Devleti'nin son döneminde İstanbul'un şarkiyat araştırmaları ve şarkiyat âlimleri açısından ne anlam ifade ettiğinin de sorgulanması gerekmektedir. O yıllarda ilmî faaliyetler için hâlâ cazibe merkezi olmayı sürdüren İstanbul'un entelektüel muhitinin ve kütüphanelerin, Batılı şarkiyat âlimlerinin çalışmalarına sağladığı katkıların bu seçimde kilit rol oynadığı muhakkaktır.

2 Bu ikinci koleksiyondaki Arapça yazmalar için dört ciltten müteşekkil bir katalog hazırlanmıştır (Rosemarie Quiring-Zoche, Arabische Handschriften. Die Handschriften der Sammlung Oskar Rescher in der Staatsbibliothek zu Berlin-Preussischer Kulturbesitz (Stuttgart: Franz Steiner Verlag, 1994-2015)). Bu koleksiyondaki 500 cilt civarında Türkçe yazmanın ise 2019-2020 yıllarında yürüttügümüz "Berlin Devlet Kütüphanesi’nde Bulunan Kayıtsız Türkçe Yazmaların Tespiti” adlı proje kapsamında tarafımızca tespit fişleri oluşturulmuştur.

3 Bu konudaki değerlendirmelerimiz için bkz. Doğan Averbek - Hanstein, “Oskar Rescher,” 389, 408, 448. 
Reşer, Türkiye'de yaşadığı yıllarda muhtelif görevlerde bulundu. ${ }^{4}$ Son zamanlarında Harbiye'de bulunan Artigiana Düşkünler Evi'nde kaldı. 1 Ocak 1972'de hastaneye kaldırıldı. 26 Mart 1972'de vefat etti.

Reşer - tespit edebildiğimiz kadarıyla- etüt-tercümeler dâhil olmak üzere 58 kitap, 76 makale, 68 yayın değerlendirme, 5 kitap tercümesi, 2 makale tercümesi neşretti.

Reşer'in Berlin Devlet Kütüphanesi ile profesyonel manada yazma ticareti 1924'te başlamıştır. Fakat bundan önce 1913-1914 yıllarında Reşer vasıtasıyla sekiz adet yazma, koleksiyona dâhil edilmiştir. Netice olarak Reşer, 1913-1936 yılları arasında Berlin Devlet Kütüphanesi açısından aktif bir yazma tedarikçisidir, temin ettiği yazmaların adedi 1192'dir. Bu yazmaların yarıdan fazlası Türkçedir.

Almanya'nın değişen şartları sebebiyle Reşer'in Berlin Devlet Kütüphanesi ile irtibatı 26 Ağustos 1936 tarihinde kesildi. Bu, kütüphane ile 20 Eylül 1971'de gönderdiği kartpostala kadarki son bağlantısıdır. Sözü edilen tarihte teklif ettiği yazma, kütüphane tarafından satın alınmadı. Reşer, kartpostaldaki tarihten altı ay sonra İstanbul'da hayata veda etti.

Reşer, Türkiye'de bulunduğu yıllarda bir misyon edinmişçesine sahaflardan seçtiği yazmaları yurt dışındaki kütüphanelere ve sahaflara uygun bedellerle sattı. Sattığı yazmalar gerek fizik özellikleri bakımından gerekse muhteva açısından özenle seçildiği anlaşılan yazmalardır. Aralarında kayıp eserler, tek nüshası olan eserler, otograf nüshalar ile hatırı sayılır miktarda saray yazması mevcuttur. Özellikle yakın tarihte kütüphaneye satılan yazmaların bir kısmının tereke satışlarından seçildiği anlaşılmaktadır.

Reşer'in, döneminde her yerde kolayca bulunabilen, halk arasında çok okunan, muhteva olarak öne çıkmayan yazmaları özellikle göndermediği söylenebilir. Ayrıca kondüsyonu iyi olmayan bazı yazmaları muhtemelen muhtevası sebebiyle göndermiştir.

Yazmaların önemli bir kısmı Reşer'den iz taşır. Çoğu zaman gerekli gördüğü bilgileri kurşunkalemle baş tarafa, nadiren de sona yazmış, yazmanın diğer kataloglardaki nüshalarına işaret etmiştir.

Reşer'den alınan yazmalar ayrı bir koleksiyon olarak değerlendirilmemiş, bunlara gönderildikleri zamana göre ardışık raf numarası verilmemiştir. O dönemde kütüphanede cari olan usule göre ebatlarına göre kategorize edilen yazmalara aynı ebat kodları içinde ardışık olmayan sayılar verilmiştir. Kataloglanma süreci de nizami değildir. Bugün Reşer yazmaları arasında kataloglanmamış olanlar mevcuttur.

Kanaatimizce Reşer, 1192 yazma arasından sadece Ms. or. quart. 1988 raf numaralı yazmanın bugüne ulaşmasını sağlamış olsaydı dahi büyük bir hizmet ifa etmiş sayılacaktı. Berlin'e

4 Tespit edebildiğimiz kadarıyla Reşer, Türkiye'de bulunduğu yıllarda şu kurumlarda görev ifa etmiştir: İstanbul Erkek Lisesi, 1923-27; Harbiye Mektebi, 1927-39; Darülfünun, 1928-33; Gülhane Hastahanesi (Ankara), 1942; Arkeoloji Müzesi, 3,5 sene görev yapmış, yaş haddi sebebiyle ayrılmıştır; Süleymaniye Kütüphanesi, 9 Aralık 1950-5 Haziran 1957; İmam-Hatip Okulu, 1958 Nisan'ından itibaren birkaç ay devam etmiştir; Topkapı Sarayı Müzesi Kütüphanesi, 1963; İstanbul Üniversitesi, Edebiyat Fakültesi, İslam Araştırmaları Enstitüsü, 31 Mayıs 1957-resmen 29 Şubat 1968, fiilen 30 Nisan 1968. 
ulaştığında oldukça kötü bir hâlde bulunan söz konusu yazma, tertip edenlerce "Mecmua-i Yek-dest" olarak isimlendirilmiştir. 17. asırda çok okunan eserleri bir arada sunması bakımından mühim kıymeti haiz olan bu yazma üzerinde tarafımızca bir dizi çalışma yürütülmektedir. 


\section{Introduction ${ }^{1}$}

Many of the libraries in Europe and America that have Islamic manuscripts in their collection owe part of the size of their statistical data to Oskar Rescher (aka Osman Reşer, 1883-1972). He was a global trader and broker of manuscripts, deserving of the title of probably the most active trader of Islamic manuscripts of the $20^{\text {th }}$ century, which he sold to many countries. This aspect of his has gone unnoticed. Islamic manuscripts sold by Rescher are available today in the British Library (then the British Museum), Cambridge University Library, Bodleian Library, Uppsala University Library, Basel University Library, Beinecke Rare Book and Manuscript Library at Yale, University of California Libraries, the Vatican Library, and the Austrian National Library.

Hundreds of Turkish, Arabic, and Persian manuscripts have been included in the collections of libraries in Munich, Hamburg, Leipzig, Göttingen, Tübingen, and Halle through the expertise and trade activity offered by Rescher, who had established a limited network of relations with his field between Turkey and Germany during his time in Istanbul. A significant portion of the manuscripts the Berlin State Library bought in the $20^{\text {th }}$ century had been obtained through Rescher. These manuscripts are the ones Rescher gradually sold to the library between 19131936.

Meanwhile, the 1,722 volumes that were sold to the Berlin State Library after Rescher's death and purported to be his personal collection ${ }^{2}$ had nothing to do with Rescher according to our investigations. ${ }^{3}$ These manuscripts were sold to the library by Ayla König (1918?-1993) in 1974. We are unsure as to how the process had occurred, as all correspondence regarding this purchase has been lost.

This study will involve discussions about the manuscripts Rescher sold to the Berlin State Library between 1913-1936 after briefly touching upon his life story; the study will also present a detailed list of the manuscripts. This list was created by examining the library's acquisition journal and inventory notebooks, scanning the printed and digital catalogues, and viewing all the manuscripts that had been obtained by way of Rescher. To our knowledge, no list or inventory study has ever been done prior to our study at the library or anywhere else regarding these manuscripts.

1 The information contained in this section is in part based on our extensive study of Rescher (please see Güler Doğan Averbek - Thoralf Hanstein, "Oskar Rescher - Biographical Finds around Manuscripts, Books and Libraries," Sammler - Bibliothekare - Forscher: Beiträge zur Geschichte der Orientalischen Sammlungen an der Staatsbibliothek zu Berlin, ed. Sabine Mangold-Will, Christoph Rauch, Siegfried Schmitt (Frankfurt/Main: Vittorio Klostermann Verlag, 2021, 387-449)). Thus, thanks to Dr. Hanstein for his contribution and permission that this study presents in the introduction section.

2 A 4-volume catalogue has been prepared for the Arabic manuscripts in this second collection (Rosemarie QuiringZoche, Arabische Handschriften. Die Handschriften der Sammlung Oskar Rescher in der Staatsbibliothek zu Berlin-Preussischer Kulturbesitz (Stuttgart: Franz Steiner Verlag, 1994-2015)). We created the identification cards for around 500 volumes of Turkish manuscripts in this collection within the scope of the project titled "Berlin Devlet Kütüphanesi'nde Bulunan Kayıtsız Türkçe Yazmaların Tespiti” [Detecting Uncatalogued Turkish Manuscripts in the Berlin State Library], which we conducted in 2019-2020.

3 For our evaluations on this topic, please see Doğan Averbek - Hanstein, "Oskar Rescher," 389, 408, 448. 


\section{Oskar Rescher}

Rescher was born on October 1, 1883 in Stuttgart as the only child of Adolf and Leopoldina; his full name was Oskar Emil Rescher. After becoming a Turkish citizen in 1937, he took the name Osman Yaşar Reşer. In addition to his mother tongue, he was fluent in Arabic, Persian, Turkish, Greek, Latin, French, Spanish, English, Russian, and Danish. He started studying law at the University of Munich in 1903; in 1905, he transferred to the Department of Oriental Languages in the Faculty of Philology at Friedrich-Wilhelms-Universität zu Berlin (today Humboldt University of Berlin), from which he graduated on October 20, 1908. He received the title of doctor in 1909 and attended Leipzig University from 1909-1910 to finish his education.

Rescher, who had been visiting Istanbul since 1909, studied manuscripts in Istanbul and Bursa by obtaining official permission throughout these trips and published the results of these studies. He began to publish articles in many journals around this time, as well as books that he'd prepared in Istanbul with the particular support of both manuscripts and İsmail Saib Efendi (1873-1940). This period when he prepared his works for publication and developed himself under the patronage of İsmail Saib Efendi with their master-disciple and in fact friendly relationship, ended with the outbreak of World War I that was affecting the whole world. He was summoned to the military and moved to his post within 24 hours. He was stationed first in Montmédy, and then at the Halbmondlager POW Camp in Wünsdorf, near Berlin.

He received the title of associate professor from the University of Breslau in 1919 with his thesis titled "Studien über den Inhalt von 1001 Nacht," which he dedicated to Carl Brockelmann (1868-1956). He became a professor in 1925.

Rescher, who had left Istanbul urgently in 1914, was only able to return to this city in 1925 at the age of 42, after the Ottoman State had disappeared from the stage of history; he spent the rest of his life on Turkish soil, mostly in Istanbul.

Having arrived in Istanbul prior to the Balkan Wars, Rescher's journey was the beginning of a chain of events that would lead to him making Istanbul his home in the future. Rescher, who had turned to Orientalism and received the title of doctor in the field of Oriental languages by terminating his law studies in Munich, researched ways to become educated in this field and chose to settle in Istanbul. Questioning what meaning Istanbul had in the last stage of the Ottoman Empire in terms of Orientalist research and Orientalist scholars as well as the environment Rescher had encountered and relationships he had formed in this city is necessary when examining his reasons for settling in Istanbul. Certainly the intellectual environment and libraries of Istanbul, which was still a center of attraction for scholarly activities in those years, played a key role in this choice.

With the decree published in the Turkish Official Gazette dated June 2, 1937, Rescher became a Turkish citizen. He held a number of positions during his years in Turkey. ${ }^{4}$ His

$4 \quad$ As far as we have been able to determine, Rescher performed the following duties during his years in Turkey: Istanbul High School, 1923-27; Military School, 1927-39; Darülfünun (today’s Istanbul University), 1928-33; Gülhane Military Hospital (Ankara), 1942; Archeology Museum, worked for 3.5 years, left due to age restrictions; Süleymaniye Library, December 9, 1950-June 5, 1957; İmam-Hatip School, continued for a few months starting in April 1958; The Archive and Library of the Topkap1 Palace Museum, 1963; İstanbul University Faculty of Literature, Center for Islamic Studies, May 31, 1957- February 29, 1968 (officially), April 30,1968 (de facto). 
old age he spent struggling with illnesses. In his final days, he stayed at the Artigiana OldPeople's Home in the Harbiye neighborhood of Istanbul's Şişli District. He was hospitalized on January 1, 1972 with a broken arm, enlarged prostate, and extreme exhaustion. He could no longer walk. He passed away on Sunday night, March 26, 1972 at 11:30 p.m. He is buried in Silivrikapı Cemetery. Muzaffer Ozak, Salih Tuğ, and Yusuf Ziya Kavakçı were among those who attended his funeral ceremony at Bayezid Mosque. Muzaffer Ozak, who led the funeral prayer, was also among those who lowered the deceased into his grave.

Rescher continued to work without interruption from the first article he published in 1909 until his death. As far as we could determine, he published 58 books, 76 articles, 68 book reviews, five book translations, and two article translations throughout this period.

\section{The Manuscripts Rescher Sold to the Berlin State Library}

Rescher's professional manuscript trade with the Berlin State Library began in 1924. However, eight manuscripts had been added to the collection through Rescher before this between 1913-1914. According to us, Rescher had obtained these eight manuscripts from Istanbul and had planned his manuscript trade at that time, but the war had intervened. He started going back and forth to Istanbul in 1924 while he was working in Breslau after the war; within a year he permanently left Germany and settled in Istanbul. As a result, Rescher had been an active supplier of manuscripts to the Berlin State Library between 1913 and 1936, procuring 1,192 manuscripts.

Rescher mostly sent the manuscripts by mail. More than half the manuscripts he provided were in Turkish. He likely attempted to procure Turkish manuscripts through requests from the library. No correspondence exists regarding Rescher's manuscript trade, which was in operation for 23 years.

Due to the changing conditions in Germany, Rescher's contact with the Berlin State Library was shut down following the sale of 10 volumes of manuscripts on August 26, 1936. This was his last contact with the library until the postcard he sent on September 20,1971. On this date, he offered the library the complete works of Sa'dî-i Şirazî, which consisted of 640 folios and contained 24 miniatures; however, the library found the price so high that it would not purchase the manuscript. Rescher passed away in Istanbul six months after the date on the postcard.

Apart from the miscellaneous duties he performed in Ankara where he had lived for a little while and in Istanbul where he consistently resided, Rescher's unvarying task was book trade, particularly manuscript trade. He sold the manuscripts he'd selected from the second-hand bookstores to libraries and second-hand bookstores abroad at reasonable prices as if he were on a mission. The manuscripts were as uncommon as the low fees he requested. These appear to have been manuscripts that had been carefully selected in terms of both physical features and content. Among these are lost works, unique copies of works, autographed copies, and a considerable amount of palace manuscripts. According to what is understood in particular 
from the ownership records and stamps on the manuscripts sold to the library in recent times, some of the manuscripts had been selected from estate sales. The manuscript market is known to have been rich at that time due to the dervish lodges and madrasas that had been closed down; manuscripts could even be purchased cheaper than printed books.

According to what is understood from the records in the acquisition journal, Rescher occasionally received no fee for some manuscripts. In particular, he can be said to have not sent manuscripts in that period that could easily be found anywhere, that were widely read among the public, and that did not stand out in terms of content. However, he did send different copies of some manuscripts. These different copies being found within the same shipment shows that this was a conscious behavior. He also sent some manuscripts that were not in good condition, probably because of their content.

A significant portion of the manuscripts carry traces from Rescher. Most of the time he would pencil in the necessary information on the inside cover, rarely at the end; he would indicate copies of the manuscript that were in other catalogues. From time to time, the pages of notes Rescher sent were seen to be attached to the relevant manuscript. Rescher may have benefitted from İsmail Saib Efendi while gathering this information.

The manuscripts received from Rescher were not considered a separate collection, nor were they given consecutive shelf numbers with respect to when they had been sent. Nonconsecutive numbers within same-size codes were given to the manuscripts, categorizing them with respect to size in accordance with the current procedure of the library at that time. The cataloguing process was also irregular. Uncatalogued manuscripts are currently found among the Rescher manuscripts.

\section{Conclusion}

This study brings two basic claims to the agenda beyond the detailed list it contains. The first of these is that the information regarding the manuscripts sold to the Berlin State Library after Rescher's death as being Oskar Rescher's personal manuscripts collection is incorrect. These 1,722 manuscripts form a sub-par collection in terms of both physical characteristics and content and do not belong to Rescher. These manuscripts, which we know to have come from Istanbul, could easily be found in the city's second-hand bookstores at the time they were sold to the library.

The focus of this study is on the manuscripts Rescher sold to the Berlin State Library between 1913-1936 by procuring them from Turkish lands. The number and contents of these manuscripts as well as the magnitude of these trade activities had been unknown until today. The number of these manuscripts, which is enough to establish a remarkable library in terms of physical characteristics and content, is 1,192.

The manuscripts Rescher had provided are seen to have subjects that can be found in almost every manuscript collection. The subject headings can be exemplified as Qur'an, Qur'anic 
sciences, tafsir, qalam and aqidah, hadith, fiqh, faraiz, fatwas, catechism, Sufism, lineages, morality, dictionaries, versified dictionaries, grammar, divans, mathnavis, poetry majmuas, stories, history, law, prose majmuas, books on tabaqat (Islamic biographical collections organized by century), books on the life of the Prophet, manaqib (biographies emphasizing an individual's merits, virtues, and remarkable deeds), geography, numerology, astrology, astronomy, algebra, geometry, chemistry, physics, diaries, calendars, medicine, biology, botany, and zoology.

In our opinion, Rescher would be considered to have performed a great service even if of the 1,192 manuscripts only the one shelf numbered as Ms. or. quart. 1988 had survived to the present. This manuscript, which was in a rather poor state when it arrived in Berlin, was given the name "Mecmua-i Yek-dest" by the compilers. We are conducting a series of studies on this manuscript, which has significant value in terms of presenting the works that were being widely read in the $17^{\text {th }}$ century.

This study is hoped to open the door to other new studies. In addition, this study will pave the way for publishing lists of the manuscripts that Rescher had sold to other libraries, thus contributing to the creation of an inventory of the manuscripts that were sent abroad from Istanbul when the Ottoman State had been withdrawn from the stage of history.

Peer-review: Externally peer-reviewed.

Conflict of Interest: The author has no conflict of interest to declare.

Grant Support: This study received financial support from the Prussian Cultural Heritage Foundation with the title "Reconstruction of Oskar Rescher's Life and Works as an Orientalist".

Hakem Değerlendirmesi: Dış bağımsız.

Çıkar Çatışması: Yazar çıkar çatışması bildirmemiştir.

Finansal Destek: Bu çalışma, "Reconstruction of Oskar Rescher's Life and Works as an Orientalist: A Life between Germany and Istanbul” adıyla Stiftung Preußischer Kulturbesitz'in maddi desteğini almıştır.

\section{References}

Assfalg, Julius - Joseph Molitor. Armenische Handschriften. Wiesbaden: Franz Steiner Verlag, 1962. [4]

Doğan Averbek, Güler - Thoralf Hanstein. "Oskar Rescher - Biographical Finds around Manuscripts, Books and Libraries." Sammler - Bibliothekare - Forscher: Beiträge zur Geschichte der Orientalischen Sammlungen an der Staatsbibliothek zu Berlin. ed. Sabine Mangold-Will, Christoph Rauch, Siegfried Schmitt. Frankfurt/ Main: Vittorio Klostermann Verlag, 2021, 387-449.

Eilers, W. - W. Heinz. Persische Handschriften. c. 1. Wiesbaden: Franz Steiner Verlag, 1968. [14/1] Flemming, Barbara. Türkische Handschriften, c. XIII/1, Wiesbaden: Franz Steiner Verlag, 1968. [13/1]

Götz, Manfred. Türkische Handschriften, c. XIII/2, Wiesbaden: Franz Steiner Verlag, 1968. [13/2]

Götz, Manfred. Türkische Handschriften, c. XIII/4, Wiesbaden: Franz Steiner Verlag, 1979. [13/4]

KOHD (Katalogisierung der Orientalischen Handschriften in Deutschland [Almanya Şarkiyat Yazmaları Toplu Katalogu], https://orient-mss.kohd.adw-goe.de/)

Kraemer, Jörg. Persische Miniaturen und ihr Umkreis: Buch- und Schriftkunst arabischer, persischer, türkischer und indischer Handschriften aus dem Besitz der früheren Preussischen Staats- und der Tübinger Universitätsbibliothek. Tübingen: Der Kunstverein, 1956. 
“Orientalische Handschriften Zugangsbuch, 1919-.” Ms. Berlin State Library, Oriental Department.

Quiring-Zoche, Rosemarie. Arabische Handschriften: Die Handschriften der Sammlung Oskar Rescher in der Staatsbibliothek zu Berlin-Preussischer Kulturbesitz c. XVII/3, 5-7. Stuttgart: Franz Steiner Verlag, 1994-2015.

Schoeler, Gregor. Arabische Handschriften. Reihe B. c. 2. Stuttgart: Franz Steiner Verlag, 1990. [17B/2]

Schoeler, Gregor. Arabische Foliobände der Staatsbibliothek zu Berlin. c. 14. Stuttgart: Franz Steiner Verlag, 2020. [17B/14]

Sellheim, Rudolf. Arabische Handschriften. Reihe A: Materialien zur arabischen Literaturgeschichte. c. 1. Wiesbaden: Franz Steiner Verlag, 1976. [17A/1]

Sellheim, Rudolf. Arabische Handschriften. Reihe A: Materialien zur arabischen Literaturgeschichte. c. 2. Wiesbaden: Franz Steiner Verlag, 1987. [17A/2]

Sohrweide, Hanna. Türkische Handschriften. c. XIII/3. Wiesbaden: Franz Steiner Verlag, 1974. [13/3]

Sohrweide, Hanna. Türkische Handschriften, c. XIII/5, Wiesbaden: Franz Steiner Verlag, 1981. [13/5]

"Standortverzeichnis der Orientalischen Handschriften der Preußischen Staatsbibliothek: Orientalische Handschriften in folio.” Ms. Berlin State Library, Oriental Department.

"Standortverzeichnis der Orientalischen Handschriften der Preußischen Staatsbibliothek: Orientalische Handschriften in quarto.” Ms. Berlin State Library, Oriental Department.

"Standortverzeichnis der Orientalischen Handschriften der Preußischen Staatsbibliotheken: Orientalische Handschriften in octavo.” Ms. Berlin State Library, Oriental Department.

Stchoukine, Ivan vd. Illuminierte islamische Handschriften. Wiesbaden: Franz Steiner Verlag, 1971. [16/1]

Wagner, Ewald. Arabische Handschriften. Reihe B. c. 1. Wiesbaden: Franz Steiner Verlag, 1976. [17B/1] 


\section{The Manuscripts Rescher Sold to the Berlin State Library (Reșer'in Berlin Devlet} Kütüphanesi'ne Sattığı Yazmalar)

\begin{tabular}{|c|c|c|c|}
\hline Nr. & $\begin{array}{l}\text { Date }^{5} \\
\text { Tarih }^{6}\end{array}$ & $\begin{array}{c}\text { Name of Work, Name of Author (Language; Catalogue } \\
\text { Information) } \\
\text { Eser adı, Müellif adı (Dil; Katalog Bilgisi) }\end{array}$ & $\begin{array}{l}\text { Shelf nr. } \\
\text { Raf nr. }\end{array}$ \\
\hline 1. & 27.05.1913 & $\begin{array}{l}\text { Haḳikatü'l-beyān-l şāhiye, Muhammed 'Alī b. İskender eş- } \\
\text { Şirvānī }(\mathrm{F} ; 14 / 1,75)\end{array}$ & Ms.or.oct. 1249 \\
\hline 2. & 22.08.1913 & Şerhü Kitābi’l-Burhān li-Arisțātālīs, İbn Rüşd (A; 17B/2, 131) & Ms.or.fol. 3176 \\
\hline 3. & 14.11.1913 & Şațranc-nāme-i kebīr, Firdevsī-i Rūmī (T; 13/3, 328) & Ms.or.oct. 1631 \\
\hline 4. & 29.12.1913 & Muhtār min Resā’’ili Cāḥız, 'Amr b. Baḥr el-Cāḥız (A; KOHD) & Ms.or.oct. 1499 \\
\hline 5. & 04.02 .1914 & $\begin{array}{c}\text { el-'Ascedü'l-Mesbūk fì men veliye'l-Yemen mine'l-mülūk, 'Alī b. } \\
\text { Hasan el-Hazrecī (A; KOHD) }\end{array}$ & Ms.or.quart. 1214 \\
\hline 6. & 04.02 .1914 & $\begin{array}{l}\text { Kitābu'l-Emșāli’ṣ-șādire 'an büyūti'ş-şi 'r, Hamza el-Iṣfahānī (A; } \\
\text { 17B/2, 280) }\end{array}$ & Ms.or.quart. 1215 \\
\hline 7. & 1914 & $\begin{array}{c}\text { Delā'il ve'l-i tibār 'ale'l-halk ve't-tedbīr, 'Amr b. Baḥr el-Cāḥız } \\
\text { (A; KOHD) }\end{array}$ & Ms.or.oct. 1501 \\
\hline 8. & 1914 & $\begin{array}{c}\text { Tafșīlü 'ikdi'l-fevā'id ve tekmīlü Kaydi 'ş-şerā'id, 'Abdülberr b. } \\
\text { Muhamamed İbn eş-Şiḥne (A; KOHD) }\end{array}$ & Ms.or.oct. 1502 \\
\hline 9. & 25.03.1924 & Dua kitabı [Prayer book] (Rusça [Russian]) & Ms.slav.quart. 31 \\
\hline 10. & 14.10.1924 & 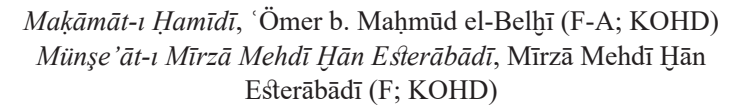 & Ms.or.oct. 2088 \\
\hline 11. & 11.11.1924 & Dīvān, Zuhurīi-i Türşīzī (F; 14/1, 308) & Ms.or.quart. 1392 \\
\hline 12. & 11.11.1924 & $\begin{array}{c}\text { Bahrü's-sa 'āde, Muhammed b. Muhạammed İbn İbrāhīm } \\
\text { Tāceddīn (F; 14/1, 336) }\end{array}$ & Ms.or.quart. 1405 \\
\hline 13. & 11.11.1924 & $\begin{array}{c}\text { Dìvān, 'Abdurraḥmān b. Muhammed Selīm (Kürtçe [Kurdish]-F; } \\
14 / 1,67)\end{array}$ & Ms.or.oct. 2161 \\
\hline 14. & 11.11.1924 & $\begin{array}{l}\text { 1. Ķānūnu'r-Reşād, Nergisīi (T; 13/3, 130) } \\
\text { 2. Hüsn ü Dil, Āhī Hasan Çelebi (T; 13/3, 314) }\end{array}$ & Ms.or.oct. 2059 \\
\hline
\end{tabular}

5 This column contains the date the manuscript was recorded in the library's acquisition journal.

6 Bu sütunda, yazmanın kütüphane sağlama defterine kaydedildiği tarih yer almaktadır.

7 Within the parentheses used in this column A is used for Arabic works, T for Turkish works, F for Persian works, and Ç for Chagatai Turkish. The note written following the language information shows the catalogue process of the work. The numbers found after the printed catalogue keys (e.g., 13/1) indicate the respective entry number of the work in the relevant catalogue. The printed catalogue keys are shown in brackets at the end of the relevant volume in the study's bibliography. The GDA key indicates manuscripts that have not been catalogued but that we have created identification slips for, while the UC key indicates manuscripts that have not yet been catalogued. The expansion and link address of the KOHD key, which indicates the digital catalogue, is provided in the bibliography.

8 Bu sütunda parantez içinde kullanılan A, Arapça eserleri; T, Türkçe eserleri; F, Farsça eserleri; Ç, Çağatay Tükçesiyle yazılan eserleri göstermektedir. Dil bilgisinden sonra gelen not, yazmanın katalog sürecini göstermektedir. 13/1 gibi matbu katalog rumuzlarından sonra yer alan numaralar, eserin ilgili katalogdaki girdi numarasını göstermektedir. Matbu katalog rumuzları, çalışmanın bibliyografyasında ilgili cildin sonunda köşeli ayraç içerisinde gösterilmiştir. GDA rumuzu, kataloglanmamış olup tarafımızca tespit fişleri oluşturulan yazmaları, UC rumuzu ise henüz kataloglanmamış yazmaları göstermektedir. Dijital kataloga işaret eden KOHD rumuzunun açılımı ve bağlantı adresi bibliyografyada verilmiştir. 
The Manuscripts Rescher Sold to the Berlin State Library (Reşer'in Berlin Devlet Kütüphanesi'ne Sattığı Yazmalar)

\begin{tabular}{|c|c|c|c|}
\hline Nr. & $\begin{array}{l}\text { Date } \\
\text { Tarih }\end{array}$ & $\begin{array}{c}\text { Name of Work, Name of Author (Language; Catalogue } \\
\text { Information) } \\
\text { Eser adı, Müellif adı (Dil; Katalog Bilgisi) }\end{array}$ & $\begin{array}{l}\text { Shelf nr. } \\
\text { Raf nr. }\end{array}$ \\
\hline 15. & 11.11.1924 & Düstūrü'l- 'amel, Pīr Meḥmed (T; 13/2, 192) & Ms.or.oct. 2094 \\
\hline 16. & 11.11.1924 & Ahvāl-i ġazavāt der-diyār-ı Bosna, 'Ömer Efendi $(\mathrm{T} ; 13 / 4,240)$ & Ms.or.oct. 2093 \\
\hline 17. & 11.11.1924 & Şerh-i Bostān, Şem ‘̄i (T; 13/2, 629) & Ms.or.oct. 2087 \\
\hline 18. & 11.11 .1924 & Tārīh-i Cizyedārzāde, Cizyedārzāde Aḥmed Bahā'eddīn (T; 13/1, & Ms.or.fol. 3347 \\
\hline 19. & 11.11.1924 & Behcetü 't-tevārīh, Şükrullāh b. Şihābeddīn $(T ; 13 / 1,12)$ & Ms.or.fol. 3349 \\
\hline 20. & 17.01.1925 & $\begin{array}{c}\text { 'Abdullāh-1 İlāhī: } \\
\text { 1. Esrār-nāme }(\mathrm{T} ; 13 / 2,55) \\
\text { 2. Meslekü'ț-țālibīn ve'l-vāṣ̂llīn }(\mathrm{T} ; 13 / 2,63)\end{array}$ & Ms.or.quart. 1471 \\
\hline 21. & 17.01 .1925 & Dìvān, Fehīm $(\mathrm{T} ; 13 / 2,333)$ & Ms.or.oct. 2158 \\
\hline 22. & 17.01.1925 & Müyessiretü'l- 'ulūm, Berġamalı Kadrī (T; 13/4, 461) & Ms.or.oct. 2056 \\
\hline 23. & 17.01.1925 & $\begin{array}{l}\text { 1. Risāle fì iktirānāti’l-kevākib, Fāżıll Hürmüz (A; UC) } \\
\text { 2. Müntehab ez-kütüb-i mu 'tebere der-ahkām-ı nücūm (F; } \\
\text { KOHD) } \\
\text { 3. İhtiyārāt ve ahkāmü'l-kevākib (T; GDA) }\end{array}$ & Ms.or.oct. 2091 \\
\hline 24. & 17.01.1925 & Terceme-i Akrāāādīn, Hayātīzāde Süleymān Efendi (T; 13/4, 419) & Ms.or.oct. 2189 \\
\hline 25. & 17.01 .1925 & 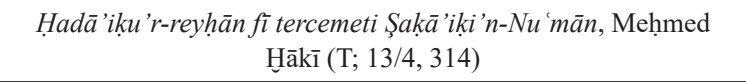 & Ms.or.oct. 2092 \\
\hline 26. & 17.01 .1925 & 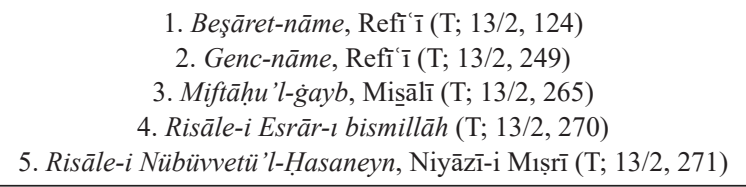 & Ms.or.quart. 1401 \\
\hline 27. & 17.01 .1925 & $\begin{array}{c}\text { İşāä̈'l-mürīd ile 'l-murād fì tercemeti Mirșādi'l- 'ibād, Kāāsım b. } \\
\text { Maḥmūd el-Karahișārī }(\mathrm{T} ; 13 / 2,85)\end{array}$ & Ms.or.quart. 1376 \\
\hline 28. & 07.02 .1925 & Zādü'l-müsāfirīn, Muhammed Mehdī b. 'Alī (F; UC) & Ms.or.oct. 2058 \\
\hline 29. & 07.02 .1925 & Resā’il, Ni 'metullāh eş-Şīrāzì (F; UC) & Ms.or.oct. 2176 \\
\hline 30. & 07.02 .1925 & Dìvān, 'Urfì-i Şīrāzì (F; 14/1, 382) & Ms.or.oct. 2067 \\
\hline 31. & 07.02 .1925 & Dìvān, 'Urfì-i Şīrāzī (F; KOHD) & Ms.or.oct. 2085 \\
\hline 32. & 07.02 .1925 & $\begin{array}{l}\text { Hāşim Mușțafā el-Üsküdārī: } \\
\text { 1. Vāridāt }(\mathrm{T} ; 13 / 2,34) \\
\text { 2. Dīvān }(\mathrm{T} ; 13 / 2,344)\end{array}$ & Ms.or.oct. 2090 \\
\hline 33. & 14.02 .1925 & Şerh-i Dīvān-ı Ebī Zu'eyb el-Hüželī, Sükkerī (A; KOHD) & Ms.or.oct. 1870 \\
\hline 34. & 14.02 .1925 & $\begin{array}{l}\text { İlm-i nücum el kitabından bir parça [Part of the guidebook on } \\
\text { astronomy] }(\mathrm{T} ; 13 / 4,378)\end{array}$ & Ms.or.oct. 2082 \\
\hline 35. & 03.03 .1925 & Muhammediye, Yazıcı́ġlı Meḥmed Efendi (T; 13/2, 11) & Ms.or.quart. 1374 \\
\hline 36. & 06.03 .1925 & $\begin{array}{c}\text { 1. Mukaddime-i Kutbeddīn, Kuṭbeddīn b. Meḥmed (T; 13/5, 21) } \\
\text { 2. Terceme-i Viḳāye (T; 13/5, 99) }\end{array}$ & Ms.or.quart. 1464 \\
\hline
\end{tabular}


The Manuscripts Rescher Sold to the Berlin State Library (Reşer'in Berlin Devlet Kütüphanesi'ne Sattığı Yazmalar)

\begin{tabular}{|c|c|c|c|}
\hline Nr. & $\begin{array}{l}\text { Date } \\
\text { Tarih }\end{array}$ & $\begin{array}{c}\text { Name of Work, Name of Author (Language; Catalogue } \\
\text { Information) } \\
\text { Eser adı, Müellif adı (Dil; Katalog Bilgisi) }\end{array}$ & $\begin{array}{l}\text { Shelf nr. } \\
\text { Raf nr. }\end{array}$ \\
\hline 37. & 30.03 .1925 & 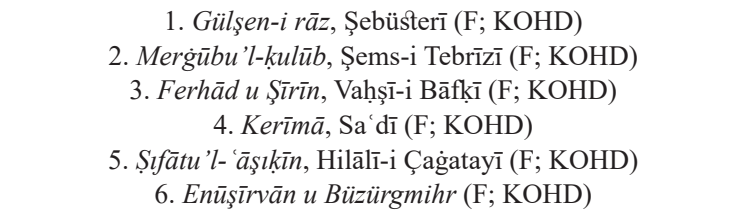 & Ms.or.oct. 1899 \\
\hline 38. & 30.03 .1925 & 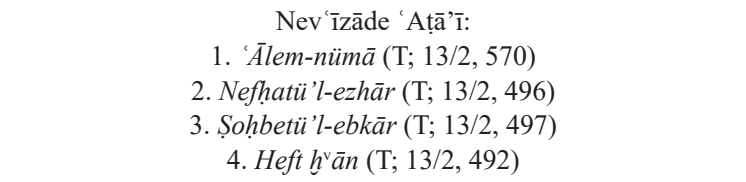 & Ms.or.oct. 2014 \\
\hline 39. & 30.03 .1925 & Dīvān, Müvālī (F; 14/1, 73) & Ms.or.oct. 1883 \\
\hline 40. & 30.03 .1925 & $\begin{array}{l}\text { 1. Dīvān, Şevket-i Buhāāī (F; KOHD) } \\
\text { 2. Dīvān-i Ġazeliyāt, Mīrzā Șūret (F; KOHD) }\end{array}$ & Ms.or.oct. 1885 \\
\hline 41. & 30.03 .1925 & Dìvān, Şevket-i Buhārī (F; 14/1, 62) & Ms.or.oct. 2017 \\
\hline 42. & 30.03 .1925 & Hümāy и Hümāyūn, Hु̄ācū-yı Kirmānī (F; 14/1, 213) & Ms.or.oct. 1900 \\
\hline 43. & 30.03 .1925 & Dìvān, Șā’ib-i Tebrīzī (F; 14/1, 60) & Ms.or.oct. 2013 \\
\hline 44. & 30.03 .1925 & Zleyl-i żeyl-i Naẓmīzāde, Naẓmīzāde Murtażā Efendi (T; 13/1, 85) & Ms.or.quart. 1346 \\
\hline 45. & 30.03 .1925 & Tekmile-i Zeyl-i Siyer-i Veysī, Nābī (T; 13/4, 201) & Ms.or.quart. 1371 \\
\hline 46. & 30.03 .1925 & Dīvān, Seyyid 'Ossmān Surūrī $(\mathrm{T} ; 13 / 2,448)$ & Ms.or.oct. 2008 \\
\hline 47. & 30.03 .1925 & el-Ferec ba'de'ş-şidde (T; 13/4, 516) & Ms.or.oct. 1882 \\
\hline 48. & 30.03 .1925 & Zleyl-i żeyl-i 'Ațā' '̄, Şeyhīi Meḥmed Efendi (T; 13/1, 282) & Ms.or.quart. 1372 \\
\hline 49. & 30.03 .1925 & Fütūhü̈ş-Şām tercemesi $(\mathrm{T} ; 13 / 1,91)$ & Ms.or.oct. 1884 \\
\hline 50. & 30.03 .1925 & Dürr-i meknūn, Aḥmed Bīcān (T; 13/4, 333) & Ms.or.oct. 1886 \\
\hline 51. & 22.04 .1925 & $\begin{array}{l}\text { 'Oșmānzāde Aḥmed Tā'ib: } \\
\text { 1. Hadīkatü'l-mülūk }(\mathrm{T} ; 13 / 1,272) \\
\text { 2. Hadīkatü'l-vüzerāa }(\mathrm{T} ; 13 / 1,278)\end{array}$ & Ms.or.fol. 3388 \\
\hline 52. & 22.04 .1925 & Kitābu'l-Fażl ve'n-nevāl, İsmā'̄il Ḥaḳk̄i Bursevī (T; 13/2, 45) & Ms.or.quart. 1350 \\
\hline 53. & 22.04 .1925 & Kitāb-ı Hoca-i cihān ve netīce-i cān, Vāḥidī $(\mathrm{T} ; 13 / 2,111)$ & Ms.or.oct. 1912 \\
\hline 54. & 22.04 .1925 & $\begin{array}{c}\text { Menāhicü'l-ușūli'd-dīniye ilā mevāḳfi'l-maḳāṣıldi'l- 'ayniye, } \\
\text { 'Abdülbāḳ̄ 'Ārif Efendi (T; 13/4, 122) }\end{array}$ & Ms.or.oct. 1913 \\
\hline 55. & 22.04 .1925 & 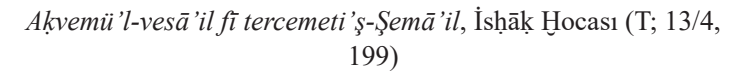 & Ms.or.oct. 2077 \\
\hline 56. & 22.04 .1925 & Mebāḥișü'l-īmān, Nuṣḥī Nāṣıḥ̄i (T; 13/4, 45) & Ms.or.oct. 1891 \\
\hline
\end{tabular}


The Manuscripts Rescher Sold to the Berlin State Library (Reşer'in Berlin Devlet Kütüphanesi'ne Sattığı Yazmalar)

\begin{tabular}{|c|c|c|c|}
\hline Nr. & $\begin{array}{l}\text { Date } \\
\text { Tarih }\end{array}$ & $\begin{array}{c}\text { Name of Work, Name of Author (Language; Catalogue } \\
\text { Information) } \\
\text { Eser adı, Müellif adı (Dil; Katalog Bilgisi) }\end{array}$ & $\begin{array}{l}\text { Shelf nr. } \\
\text { Raf nr. }\end{array}$ \\
\hline 57. & 22.04 .1925 & 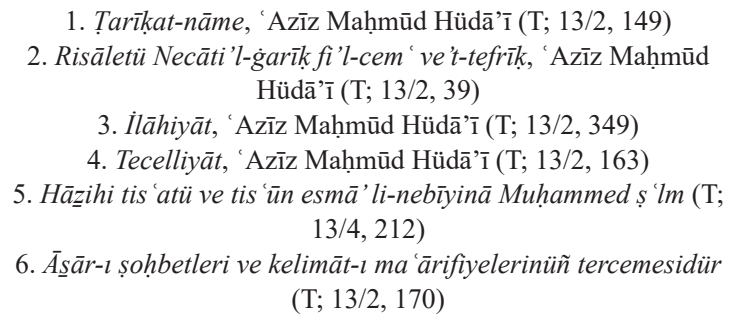 & Ms.or.oct. 2019 \\
\hline 58. & 22.04 .1925 & $\begin{array}{l}\text { 1. '̇lm-i hāal-i manẓūm }(\mathrm{T} ; 13 / 3,299) \\
\text { 2. Dürr-i meknūn }(\mathrm{T} ; 13 / 3,28)\end{array}$ & Ms.or.oct. 1911 \\
\hline 59. & 22.04 .1925 & Medḥiye, Mu'tașım (T; 13/3, 262) & Ms.or.oct. 1908 \\
\hline 60. & 22.04 .1925 & Yūsuf u Züleyhāā, Cüneydullāh Ḩāžık (F; KOHD) & Ms.or.fol. 3316 \\
\hline 61. & 22.04 .1925 & Yūsuf u Züleyhāa, Cüneydullāh Hāāık (F; KOHD) & Ms.or.quart. 1375 \\
\hline 62. & 22.04.1925 & Dīvān, 'İșmet-i Buhārīi (F; UC) & Ms.or.fol. 3319 \\
\hline 63. & 22.04 .1925 & $\begin{array}{l}\text { 1. Dīvān, Hilālīi-i Çag̉ataȳi (F; KOHD) } \\
\text { 2. Dìvān, Riyāżì (F; KOHD) } \\
\text { 3. Dìvān, Hü̈srev-i Dihlevī (F; KOHD) }\end{array}$ & Ms.or.oct. 1874 \\
\hline 64. & 22.04 .1925 & Tercemetü'ḍ-Darīr, Darīr (T; 13/1, 65) & Ms.or.fol. 3372 \\
\hline 65. & 22.04 .1925 & $\begin{array}{c}\text { Hikāyāt-ı İsfendiyār Şāh b. Fīrūz Şāh b. el-Melik Dārāa b. } \\
\text { İsfendiyār Şāh (T; GDA) }\end{array}$ & Ms.or.fol. 3391 \\
\hline 66. & 22.04 .1925 & 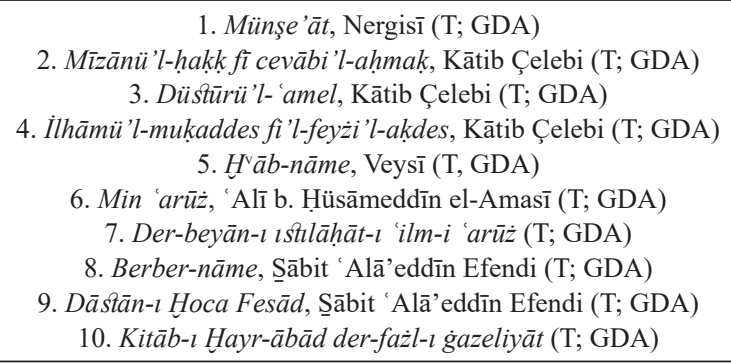 & Ms.or.fol. 3375 \\
\hline 67. & 02.05 .1925 & $\begin{array}{l}\text { Keşfü'l-gंumme 'an cemī 'i'l-ümme (el-cüz'ü'l-evvel [1 } 1^{\text {st }} \text { vol.]), } \\
\text { Ebu'l-Mevāhib 'Abdülvehhāb eş-Şa 'rānī (A; KOHD) }\end{array}$ & Ms.or.oct. 2010 \\
\hline 68. & 12.05 .1925 & Mevāhib-i 'aliye, Hüseyn Vā'izu-i Kāşifĩ (F; KOHD) & Ms.or.fol. 3329 \\
\hline 69. & 12.05 .1925 & Hāzā Risāle-i Hüseyniye el-Horasān̄i, Meḥmed Ra'nā (T; 13/2, & Ms.or.oct. 1892 \\
\hline 70. & 12.05.1925 & 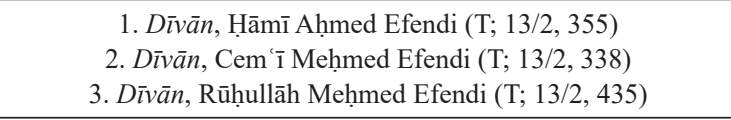 & Ms.or.quart. 1347 \\
\hline 71. & 12.05 .1925 & Manz̦ūme-i Ġavriye, Naḳșīi Aḳkirman̄̄ (T; 13/2, 71) & Ms.or.oct. 1901 \\
\hline 72. & 12.05 .1925 & Dìvān, Hevā’̄i Mușțafā Çelebi (T; 13/2, 347) & Ms.or.oct. 2036 \\
\hline
\end{tabular}


The Manuscripts Rescher Sold to the Berlin State Library (Reşer'in Berlin Devlet Kütüphanesi'ne Sattığı Yazmalar)

\begin{tabular}{|c|c|c|c|}
\hline Nr. & $\begin{array}{l}\text { Date } \\
\text { Tarih }\end{array}$ & $\begin{array}{c}\text { Name of Work, Name of Author (Language; Catalogue } \\
\text { Information) } \\
\text { Eser adı, Müellif adı (Dil; Katalog Bilgisi) }\end{array}$ & $\begin{array}{l}\text { Shelf nr. } \\
\text { Raf nr. }\end{array}$ \\
\hline 73. & 12.05 .1925 & $\begin{array}{l}\text { 1. Hulāṣatü'l-kelām fì reddi'l- 'avām, Çelebi Efendi (T; 13/1, 231) } \\
\text { 2. Tekmile-i terceme-i maḳtūl, Beşîr Ag̀a (T; 13/1, 189) }\end{array}$ & Ms.or.oct. 1889 \\
\hline 74. & 12.05 .1925 & Terceme-i Şerh-i dü-beyt, Hoca Neş’et (T; 13/2, 622) & Ms.or.oct. 1893 \\
\hline 75. & 12.05 .1925 & Dīvān, Mīr Meḥmed Dürrī (T; 13/2, 324) & Ms.or.fol. 3313 \\
\hline 76. & 12.05 .1925 & $\begin{array}{l}\text { 1. Feyżü'l-bahreyn, Mușțafā Huulūṣī }(\mathrm{T} ; 13 / 5,36) \\
\text { 2. Muḳaddimetü'l-İslām, Dāvūd-1 Karșī }(\mathrm{T} ; 13 / 5,35) \\
\text { 3. Risāle-i Írāde-i cüz'iye }(\mathrm{T} ; 13 / 5,31)\end{array}$ & Ms.or.oct. 2002 \\
\hline 77. & 12.05 .1925 & Fetāvā $(\mathrm{T} ; 13 / 3,112)$ & Ms.or.oct. 1880 \\
\hline 78. & 12.05 .1925 & Süleymān-nāme, Şemseddīn-i Sivasī (T; 13/2, 530) & Ms.or.oct. 1878 \\
\hline 79. & 12.05 .1925 & Dīvān, Ḧüseyn Şākir (T; 13/2, 450) & Ms.or.oct. 2009 \\
\hline 80. & 12.05.1925 & Dìvān, 'İzzet 'Alī Paşa (T; 13/2, 375) & Ms.or.oct. 1879 \\
\hline 81. & 12.05 .1925 & Naḳş-l hayāl, Āzerēī İbrāhīm Çelebi (T; 13/2, 500) & Ms.or.oct. 2003 \\
\hline 82. & 12.05 .1925 & $\begin{array}{l}\text { Belābilü'r-rāsiye fì riyāż̀ mesā'ili'l-Amasiye, Mușțafā Vāżı̣ (T; } \\
\qquad 13 / 3,113)\end{array}$ & Ms.or.oct. 2000 \\
\hline 83. & 12.05 .1925 & $\begin{array}{l}\text { Terceme-i Hadīka-i endiye, Meḥmed b. Süleymān el-Bag̉dādī (T; } \\
\qquad 13 / 4,146)\end{array}$ & Ms.or.oct. 1881 \\
\hline 84. & 12.05 .1925 & Gülzār, Muḥammed Sa $1 \overline{1} \mathrm{~d}(\mathrm{~F} ; 14 / 1,1)$ & Ms.or.oct. 1916 \\
\hline 85. & 12.05 .1925 & 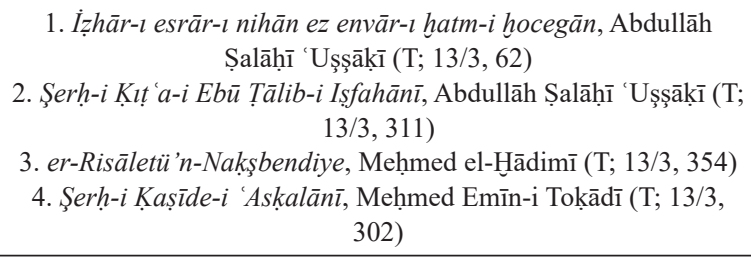 & Ms.or.oct. 1890 \\
\hline 86. & 12.05 .1925 & Kùāfet-nāme (T; 13/3, 336) & Ms.or.oct. 1917 \\
\hline 87. & 12.05 .1925 & $\begin{array}{l}\text { 1. Delīl-i budalā, Kayġusuz Abdāl (T; 13/3,84) } \\
\text { 2. Hikāye-i Şeyh Manșūr (T; 13/3, 286) }\end{array}$ & Ms.or.oct. 1914 \\
\hline 88. & 12.05 .1925 & Kenzü's-sālikīn ve gencü'l- 'ārifìn $(\mathrm{T} ; 13 / 2,126)$ & Ms.or.oct. 1915 \\
\hline 89. & 23.05 .1925 & $\begin{array}{l}\text { el-Kenzü'l-menşūr fi t't-tehni'e bi'l-a yāàd ve'l-a 'vām ve'ş-şühūr, } \\
\text { 'Abdullāh b. Muhammed es-Sükkerī (A; KOHD) }\end{array}$ & Ms.or.fol. 3317 \\
\hline 90. & 23.05 .1925 & $\begin{array}{l}\text { Füyüżu'l-ıtkān fì vücūhi'l-Ḳur'ān, Hamdullāh b. Hayreddīn (A; } \\
\text { KOHD) }\end{array}$ & Ms.or.oct. 1895 \\
\hline 91. & 23.05 .1925 & Siyer, Veysī (T; 13/4, 207) & Ms.or.oct. 1896 \\
\hline 92. & 23.05 .1925 & $\begin{array}{l}\text { 1. en-Nüketü'z-zarīfe fì tercì i mezhebi'l-İmām Ebì Hanīfe, } \\
\text { Ekmeleddīn el-Bābertī (A; KOHD) } \\
\text { 2. el-Fetāve'z-Zeyniye fì fikhi'l-Hanefiye, Zeyneddīn İbn Nüceym } \\
\text { (A; KOHD) }\end{array}$ & Ms.or.oct. 2015 \\
\hline
\end{tabular}


The Manuscripts Rescher Sold to the Berlin State Library (Reşer'in Berlin Devlet Kütüphanesi'ne Sattığı Yazmalar)

\begin{tabular}{|c|c|c|c|}
\hline Nr. & $\begin{array}{l}\text { Date } \\
\text { Tarih }\end{array}$ & $\begin{array}{c}\text { Name of Work, Name of Author (Language; Catalogue } \\
\text { Information) } \\
\text { Eser adı, Müellif adı (Dil; Katalog Bilgisi) }\end{array}$ & $\begin{array}{l}\text { Shelf nr. } \\
\text { Raf nr. }\end{array}$ \\
\hline 93. & 23.05 .1925 & 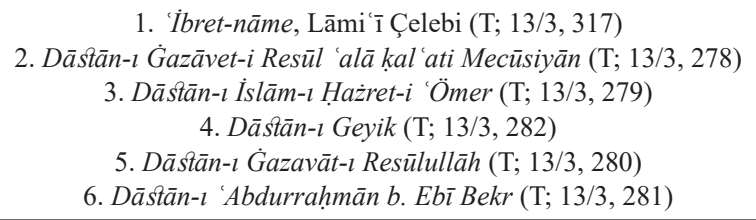 & Ms.or.oct. 2083 \\
\hline 94. & 23.05 .1925 & 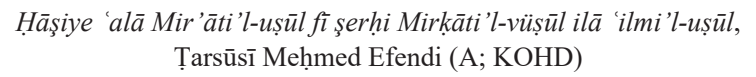 & Ms.or.quart. 1348 \\
\hline 95. & 23.05 .1925 & 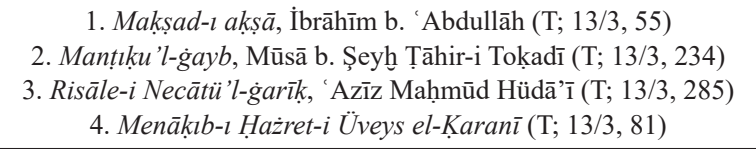 & Ms.or.oct. 1898 \\
\hline 96. & 23.05 .1925 & Ehāà̄is-i kudsiye-i ilāhiye tercemesi, 'Abdullāh Efendi (T; GDA) & Ms.or.oct. 2022 \\
\hline 97. & 23.05 .1925 & $\begin{array}{c}\text { Menāhicü'l-ușūli'd-dīniye ilā mevākıfi'l-makāṣııdi'l- 'ayniye, } \\
\text { 'Abdülbāḳ̄ 'Ārif Efendi (T; 13/4, 123) }\end{array}$ & Ms.or.oct. 1897 \\
\hline 98. & 23.05 .1925 & Baytar-nāme $(\mathrm{T} ; 13 / 4,431)$ & Ms.or.oct. 1903 \\
\hline 99. & 23.05 .1925 & 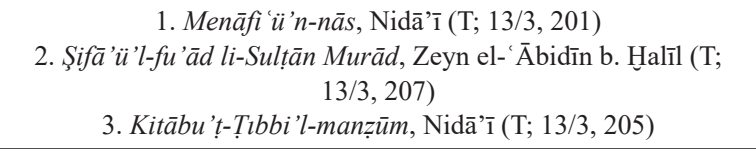 & Ms.or.oct. 2021 \\
\hline 100. & 23.05 .1925 & Dìvān, Raḥmī (T; 13/2, 424) & Ms.or.fol. 3318 \\
\hline 101. & 23.05 .1925 & Netā'icü'l-fünūn ve mehāsinü'l-mütūn, Nev'ī $(\mathrm{T} ; 13 / 4,6)$ & Ms.or.oct. 2020 \\
\hline 102. & 23.05 .1925 & $\begin{array}{l}\text { 1. Terceme-i Ferā'idü'l-ḩarā'id el-müsemmā bi- 'ukūudi'l- 'uḳūl, } \\
\text { Edirnevī Le'ālī Efendi (T; GDA) } \\
\text { 2. Esrār-l ilāhiye, Dervīş 'Arab (T; GDA) }\end{array}$ & Ms.or.oct. 1909 \\
\hline 103. & 23.05 .1925 & Dīvān, Meḥmed Nesīb (T; 13/2, 406) & Ms.or.oct. 1910 \\
\hline 104. & 23.05 .1925 & Risāle der- 'ilm-i 'arūì $(\mathrm{F} ; 14 / 1,165)$ & Ms.or.oct. 1997 \\
\hline 105. & 23.05 .1925 & $\begin{array}{l}\text { 1. Menāzilü'l- 'ārifìn, Şemseddīn-i Sivasī (T; 13/2, 94) } \\
\text { 2. Şerh-i ebyāt-l Celāleddīn-i Rumī, 'Abdülmecīd-i Sivasī (T; } \\
13 / 2,634)\end{array}$ & Ms.or.oct. 1998 \\
\hline 106. & 11.06 .1925 & Zübdetü'l-i rāb, 'Abdullāh b. Muhammed b. Velī (A; 17A/2, 116) & Ms.or.oct. 2005 \\
\hline 107. & 11.06 .1925 & Ahlāk-l 'Alā' $\bar{l}$, Ḳınalızāde 'Alī Efendi (T; 13/2, 205) & Ms.or.oct. 1872 \\
\hline 108. & 11.06 .1925 & $\begin{array}{c}\text { Mukaddimetü'l-Giaznevī, Aḥmed b. Muhammed el-Ġaznevī (A; } \\
\text { KOHD) }\end{array}$ & Ms.or.oct. 2006 \\
\hline 109. & 11.06 .1925 & Şerh-i Vașiyet-nāme-i Birgivī, 'Alī Șadrī el-Ḳonevī (T; 13/4, 52) & Ms.or.oct. 2007 \\
\hline 110. & 11.06.1925 & $\begin{array}{c}\text { Tercemetü'l- 'Uḳūdi'l-lü'lü'iye fì tarīkati's-sādeti'l-Mevleviye, } \\
\text { Şeyh 'Ārif Ahmed }(\mathrm{T} ; 13 / 2,172)\end{array}$ & Ms.or.oct. 1905 \\
\hline 111. & 11.06 .1925 & $\begin{array}{c}\text { Terceme-i Cānibü'l-garbì fì halli müşkilāti'ş-Şeyh Muhyiddīn b. } \\
\text { el-'Arabī, Aḥmed Neylī (T; 13/2, 609) }\end{array}$ & Ms.or.oct. 1904 \\
\hline
\end{tabular}


The Manuscripts Rescher Sold to the Berlin State Library (Reşer'in Berlin Devlet Kütüphanesi'ne Sattığı Yazmalar)

\begin{tabular}{|c|c|c|c|}
\hline Nr. & $\begin{array}{l}\text { Date } \\
\text { Tarih }\end{array}$ & $\begin{array}{c}\text { Name of Work, Name of Author (Language; Catalogue } \\
\text { Information) } \\
\text { Eser adı, Müellif adı (Dil; Katalog Bilgisi) }\end{array}$ & $\begin{array}{l}\text { Shelf nr. } \\
\text { Raf nr. }\end{array}$ \\
\hline 112. & 11.06 .1925 & Bostān-ı ḳuds ve gülistān-ı üns, Nūḥ Efendi (T; 13/4, 496) & Ms.or.oct. 1907 \\
\hline 113. & 11.06.1925 & Ferahü'r-rūh, İsmā̄îl Ḥaḳk̄i Bursevī (T; 13/2, 6) & Ms.or.fol. 3330 \\
\hline 114. & 11.06.1925 & $\begin{array}{c}\text { Ravżatü'ț-țālibīn ve 'umdetü'l-müftìn, Yahyā b. Şeref en-Nevevī } \\
\text { (A; KOHD) }\end{array}$ & Ms.or.fol. 3315 \\
\hline 115. & 11.06 .1925 & Șakk-i Hiżr Efendi, Hıżr b. 'Oșmān (T; 13/5, 123) & Ms.or.oct. 1999 \\
\hline 116. & 11.06 .1925 & 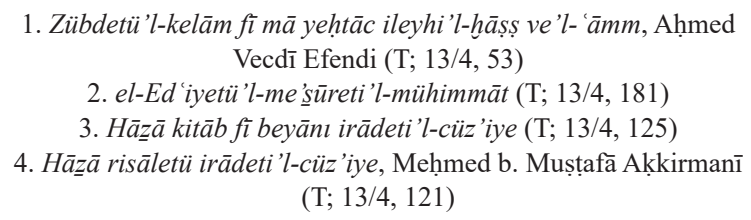 & Ms.or.oct. 1873 \\
\hline 117. & 11.06 .1925 & 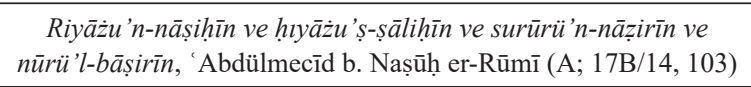 & Ms.or.fol. 3331 \\
\hline 118. & 11.06 .1925 & Nașịhatü'l-müslimīn, Meḥmed b. el-Begbāzārī (T; 13/4, 44) & Ms.or.oct. 2004 \\
\hline 119. & 11.06.1925 & Fetāvā-yı 'Alī Efendi, Çatalcalı 'Alī Efendi (T; 13/3, 111) & Ms.or.fol. 3322 \\
\hline 120. & 11.06 .1925 & $\begin{array}{l}\text { Velāyet-nāme-i Hażret-i Hünkār el-Hāāì Bektāş-ı Velī (T; 13/4, } \\
151)\end{array}$ & Ms.or.oct. 1876 \\
\hline 121. & 11.06 .1925 & $\begin{array}{c}\text { Terceme-i Şerhü Delā'ili'l-hayrāt, Kùbrīsī İbrāhīm Efendi (T; } \\
13 / 4,499)\end{array}$ & Ms.or.quart. 1408 \\
\hline 122. & 11.06 .1925 & 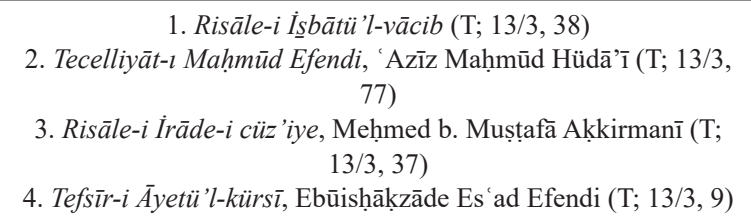 & Ms.or.oct. 1877 \\
\hline 123. & 11.06 .1925 & Burhānü’l- 'ārifìn, Selīm-i Dīvāne (T; 13/2, 89) & Ms.or.oct. 1888 \\
\hline 124. & 11.06 .1925 & Mecmū 'a-i Āyinn-i şerīf $(\mathrm{T} ; 13 / 2,121)$ & Ms.or.oct. 1875 \\
\hline 125. & 11.06 .1925 & 'Urvetü'l-íslām (T; 13/4, 55) & Ms.or.oct. 1918 \\
\hline 126. & 11.06 .1925 & Risāle-i Sì faṣl der-ma 'rifet-i taḳvìm, Aḥmed-i Dā'̄i (T; 13/4, 355) & Ms.or.oct. 1902 \\
\hline 127. & 11.06 .1925 & $\begin{array}{l}\text { 1. Şerhü̈l-Fıḳhi'l-ekber, Aḥmed b. Meḥmed el-Mag̉nisavī (A; } \\
\text { KOHD) } \\
\text { 2. el-Ḥıșnu'l-ḥașin min kelāmi Seyyidi'l-mürselīn, İbnü'l-Cezerī } \\
\text { (A; KOHD) }\end{array}$ & Ms.or.oct. 1887 \\
\hline 128. & 11.06 .1925 & $\begin{array}{l}\text { 1. Mīzānü'l-hakk fì ihtiyāri'l-ehaḳk, Kātib Çelebi (T; 13/3, 129) } \\
\text { 2. Şerh-i Ḳașīde-i Nūniye, Dāvūd-1 Karșī (T; 13/3, 303) }\end{array}$ & Ms.or.oct. 1906 \\
\hline 129. & 21.07 .1925 & $\begin{array}{l}\text { Luġat-i müşkilāt-ı Şeh-nāme, 'Abdülkāādir b. 'Ömer el-Baġdādī } \\
\text { (F-T; 13/5, 202) }\end{array}$ & Ms.or.fol. 3374 \\
\hline 130. & 21.07 .1925 & Gül ü Bülbül, Fażlī (T; 13/2, 513) & Ms.or.oct. 2134 \\
\hline
\end{tabular}


The Manuscripts Rescher Sold to the Berlin State Library (Reşer'in Berlin Devlet Kütüphanesi'ne Sattığı Yazmalar)

\begin{tabular}{|c|c|c|c|}
\hline Nr. & $\begin{array}{l}\text { Date } \\
\text { Tarih }\end{array}$ & $\begin{array}{c}\text { Name of Work, Name of Author (Language; Catalogue } \\
\text { Information) } \\
\text { Eser adı, Müellif adı (Dil; Katalog Bilgisi) }\end{array}$ & $\begin{array}{l}\text { Shelf nr. } \\
\text { Raf nr. }\end{array}$ \\
\hline 131. & 21.07.1925 & $\begin{array}{c}\text { Risāletü Kenzi'l-hidāyāt fì keşfi'l-bidāyāt ve’n-nihāyāt, } \\
\text { Muhạammed Bāḳır el-Lāhūrī (A; KOHD) }\end{array}$ & Ms.or.oct. 2102 \\
\hline 132. & 21.07.1925 & $\begin{array}{l}\text { Risāletü Halli'ț-țllsım ve keşfü's-sırri'l-mübhem fì halli'l-kīmyā, } \\
\text { Aḥmed b. Muḥammed el-Ğamrī el-Vāsițī (A; KOHD) }\end{array}$ & Ms.or.oct. 2103 \\
\hline 133. & 21.07.1925 & 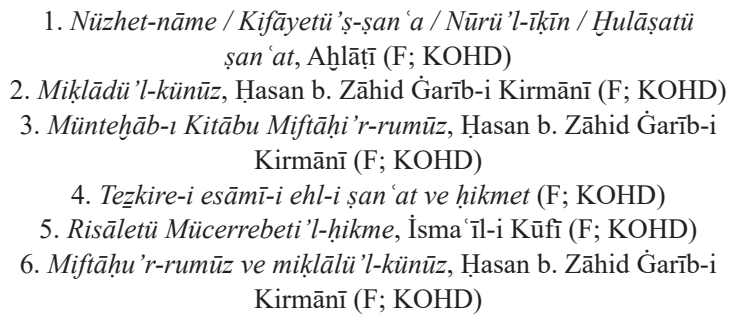 & Ms.or.oct. 2112 \\
\hline 134. & 21.07.1925 & Ehadiye risālesi tercemesi (T; GDA) & Ms.or.oct. 2198 \\
\hline 135. & 21.07 .1925 & Şerḥü'l-Hüseyniye, Meḥmed b. 'Ömer ed-Darendī (A; KOHD) & Ms.or.oct. 2191 \\
\hline 136. & 21.07 .1925 & Dìvān, Çavuşzāde 'Āṭ̂f Meḥmed Beg (T; 13/2, 318) & Ms.or.oct. 2175 \\
\hline 137. & 21.07.1925 & Șurretü'l-fetāvā, Saḳızī Șādı̣ Meḥmed Efendi (A; KOHD) & Ms.or.quart. 1454 \\
\hline 138. & 21.07.1925 & $\begin{array}{c}\text { Menārü'l-irāde li-sülūki țarīki ’s-sāde, Meḥmed b. 'Abdürrahīim } \\
\text { en-Naḳş̧bendī (A; KOHD) }\end{array}$ & Ms.or.quart. 1503 \\
\hline 139. & 21.07 .1925 & Risāle fì vahdeti'l-vücūd, Gelenbevī İsmā'̄il Efendi (A; KOHD) & Ms.or.oct. 2119 \\
\hline 140. & 21.07.1925 & $\begin{array}{c}\text { Müntehab min Fetāvā Kāậ̄ Hāān, Mușțafā b. Mușțafā (et-Takṣīr) } \\
\text { (A; KOHD) }\end{array}$ & Ms.or.quart. 1427 \\
\hline 141. & 21.07 .1925 & Tuhfetü'l-Hasīb, Seyyid Ḩal̄il Hasīb (T; 13/4, 323) & Ms.or.oct. 2106 \\
\hline 142. & 21.07 .1925 & $\begin{array}{l}\text { 1. Makāle fi'l-cimā', Mūsā b. Meymūn (A; KOHD) } \\
\text { 2. el-Maḳāletü'l-Fā̇̇̀liye, Mūsā b. Meymūn (A; KOHD) } \\
\text { 3. el-Kavlü'l-akreb fì i 'lāci les 'i’l-'akreb, Aḥmed b. } \\
\text { 'Abdülmün'im ed- Demenhūrī (A; KOHD) }\end{array}$ & Ms.or.oct. 2115 \\
\hline 143. & 21.07 .1925 & $\begin{array}{l}\text { Enīsü't-tālibīn ve 'uddetü's-sālikīn, Șalāḥ b. Mübārek el-Buhārī } \\
(\mathrm{F} ; 14 / 1,259)\end{array}$ & Ms.or.oct. 2105 \\
\hline 144. & 21.07 .1925 & $\begin{array}{c}\text { 'Abdī 'Abdülbāḳī b. Aḥmed: } \\
\text { 1. Terceme-i Kașīde-i Bürde (T; 13/5, 225) } \\
\text { 2. Terceme-i Kașìde-i Zührü'l-me'ād }(\mathrm{T} ; 13 / 5,226) \\
\text { 3. Terceme-i Kașì̄de-i Mużariye (T; 13/5, 227) }\end{array}$ & Ms.or.quart. 1497 \\
\hline 145. & 21.07 .1925 & Ferhād ile Şīrīn, Lāmi ì Çelebi (T; 13/2, 520) & Ms.or.oct. 2116 \\
\hline 146. & 21.07 .1925 & $\begin{array}{c}\text { Ayinetü'l-kulūb ve mübeyyinetü'l-ahlāk, Fażlīzāde 'Alī (T; 13/2, } \\
183)\end{array}$ & Ms.or.quart. 1432 \\
\hline 147. & 21.07 .1925 & Żavābit (T; 13/1, 388) & Ms.or.quart. 1445 \\
\hline 148. & 21.07.1925 & Fażīlet-nāme, Dervīş Meḥmed Yemīnī (T; 13/2, 255) & Ms.or.quart. 1451 \\
\hline
\end{tabular}


The Manuscripts Rescher Sold to the Berlin State Library (Reşer'in Berlin Devlet Kütüphanesi'ne Sattığı Yazmalar)

\begin{tabular}{|c|c|c|c|}
\hline Nr. & $\begin{array}{l}\text { Date } \\
\text { Tarih }\end{array}$ & $\begin{array}{c}\text { Name of Work, Name of Author (Language; Catalogue } \\
\text { Information) } \\
\text { Eser adı, Müellif adı (Dil; Katalog Bilgisi) }\end{array}$ & $\begin{array}{l}\text { Shelf nr. } \\
\text { Raf nr. }\end{array}$ \\
\hline 149. & 21.07 .1925 & 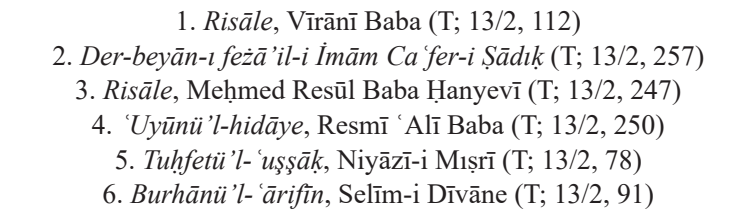 & Ms.or.quart. 1453 \\
\hline 150. & 21.07.1925 & Fetāvā-yı 'Ațā'ullāh Efendi, Meḥmed 'Ațā'ullāh Efendi (T; 13/4, & Ms.or.fol. 3362 \\
\hline 151. & 21.07.1925 & $\begin{array}{c}\text { Havāşsi’l-Yūsī 'alā Şerḥi Kübra’s-Senūsī, Hasan b. Mes ūud el- } \\
\text { Yūsī (A; KOHD) }\end{array}$ & Ms.or.quart. 1440 \\
\hline 152. & 21.07.1925 & Dìvān, Fāżıll-1 Enderūnī (T; 13/2, 329) & Ms.or.quart. 1449 \\
\hline 153. & 21.07.1925 & Hadīkatü'l-vüzerāa, 'Oșmānzāde Aḥmed Tā'ib (T; 13/1, 277) & Ms.or.fol. 3403 \\
\hline 154. & 21.07 .1925 & Težkiretü'ş-şu 'arā, Ḳınālızāde Ḥasan Çelebi (T; 13/4, 310) & Ms.or.oct. 2203 \\
\hline 155. & 12.09.1925 & 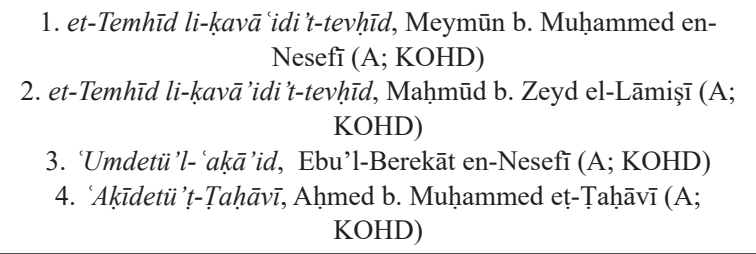 & Ms.or.oct. 2157 \\
\hline 156. & 12.09.1925 & Havāṣṣu'l-Ḳur'ān, Muḥammed b. Aḥmed et-Temīmī (A; KOHD) & Ms.or.quart. 1421 \\
\hline 157. & 12.09.1925 & $\begin{array}{c}\text { Mīzānü'l-müdde 'iyeyn fì ikāameti’l-beyyineteyn, Esīrīzāde } \\
\text { 'Abdülbāḳi b. Meḥmed (A-T; KOHD) }\end{array}$ & Ms.or.quart. 1434 \\
\hline 158. & 12.09 .1925 & $\begin{array}{l}\text { 1. Risāle fì 'ilmi'l-hisāab (T; 13/5, 172) } \\
\text { 2. Kitābu'l-Ferā'iż, Aḥmed Efendi (T; 13/5, 114) } \\
\text { 3. Cerīde-i ferā' 'iż, Șāliḥ Efendi (T; 13/5, 116) }\end{array}$ & Ms.or.fol. 3404 \\
\hline 159. & 12.09 .1925 & Meslekü'ț-țālibīn ve'l-vāṣılìn, 'Abdullāh-1 İlāhī $(\mathrm{T} ; 13 / 2,58)$ & Ms.or.quart. 1429 \\
\hline 160. & 12.09 .1925 & $\begin{array}{c}\text { Nūrü'l-hüdā li-men ihtedā, K̦araḳaşzāde 'Ömer b. Meḥmed (T; } \\
13 / 2,84)\end{array}$ & Ms.or.quart. 1422 \\
\hline 161. & 12.09 .1925 & Sirāc-l ġayb, Zeyn el- 'Ābidīn Efendi (T; 13/5, 259) & Ms.or.quart. 1433 \\
\hline 162. & 12.09 .1925 & $\begin{array}{c}\text { Terceme-i Ahvāl-i ‘ālem-i berzah, Şeyh İbrāhīm el-Bābāvī (T; } \\
13 / 2,236)\end{array}$ & Ms.or.quart. 1425 \\
\hline 163. & 12.09 .1925 & $\begin{array}{c}\text { er-Rāyetü'l-manșūre fi farżiyeti'l-kıtāl ma 'a 'l-kefereti'l-maḳhūre, } \\
\text { Aḥmed Şem ' } \overline{1}(\mathrm{~T} ; 13 / 1,389)\end{array}$ & Ms.or.quart. 1431 \\
\hline 164. & 12.09 .1925 & $\begin{array}{l}\text { 1. Terceme-i er-Risāletü'l-Välidiye }(\mathrm{T} ; 13 / 2,136) \\
\text { 2. Terceme-i Risāle-i Havrā'iye }(\mathrm{T} ; 13 / 2,637) \\
\text { 3. Terceme-i Fıkarāt }(\mathrm{T} ; 13 / 2,125) \\
\text { 4. Silsiletü'l- 'ārifin ve tezkiretü'ṣ-șādıkīn }(\mathrm{T} ; 13 / 2,160)\end{array}$ & Ms.or.quart. 1486 \\
\hline 165. & 12.09 .1925 & 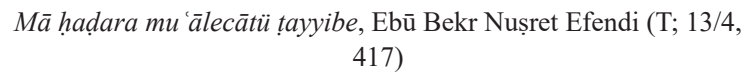 & Ms.or.oct. 2108 \\
\hline
\end{tabular}


The Manuscripts Rescher Sold to the Berlin State Library (Reşer'in Berlin Devlet Kütüphanesi'ne Sattığı Yazmalar)

\begin{tabular}{|c|c|c|c|}
\hline Nr. & $\begin{array}{l}\text { Date } \\
\text { Tarih }\end{array}$ & $\begin{array}{c}\text { Name of Work, Name of Author (Language; Catalogue } \\
\text { Information) } \\
\text { Eser adı, Müellif adı (Dil; Katalog Bilgisi) }\end{array}$ & $\begin{array}{l}\text { Shelf nr. } \\
\text { Raf nr. }\end{array}$ \\
\hline 166. & 12.09 .1925 & $\begin{array}{c}\text { Tercemetü'l-Hiy'eti's-seniye fi'l-hey'eti s-sünniye, Nazmīzāde } \\
\text { Murtażā Efendi (T; 13/4, 364) }\end{array}$ & Ms.or.quart. 1420 \\
\hline 167. & 12.09.1925 & 'Uddetü'l-Hișni'l-hașīn, İbnü'l-Cezerī (A; KOHD) & Ms.or.oct. 2118 \\
\hline 168. & 12.09.1925 & 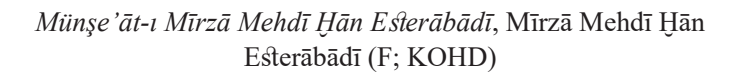 & Ms.or.quart. 1435 \\
\hline 169. & 12.09 .1925 & Tuhfetü'l-kibār fì esfäri'l-bihāā, Kātib Çelebi (T; 13/1, 160) & Ms.or.quart. 1415 \\
\hline 170. & 12.09.1925 & Dìvān, Fāżıll-1 Enderūn̄̄ (T; 13/2, 328) & Ms.or.fol. 3343 \\
\hline 171. & 12.09 .1925 & $\begin{array}{l}\text { Hāşim Mușțafā el-Üsküdārī: } \\
\text { 1. Vāridāt }(\mathrm{T} ; 13 / 2,35) \\
\text { 2. Dīvān }(\mathrm{T} ; 13 / 2,345)\end{array}$ & Ms.or.oct. 2156 \\
\hline 172. & 12.09 .1925 & Dìvān, Murtażā Sükūtī (T; 13/2, 446) & Ms.or.quart. 1419 \\
\hline 173. & 12.09.1925 & 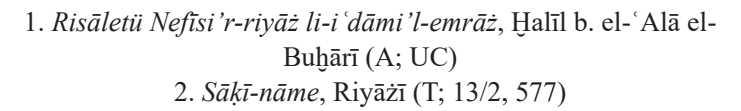 & Ms.or.oct. 2142 \\
\hline 174. & 12.09.1925 & Fażīlet-nāme, Dervīş Meḥmed Yemīnī (T; 13/2, 254) & Ms.or.quart. 1443 \\
\hline 175. & 12.09 .1925 & Dìvān, Seyyid Vehbī $(\mathrm{T} ; 13 / 2,470)$ & Ms.or.fol. 3361 \\
\hline 176. & 12.09 .1925 & Dīvān, Mușțafā 'Āṭ̂f (T; 13/2, 320) & Ms.or.quart. 1430 \\
\hline 177. & 12.09 .1925 & Mecmū 'a-i eş 'ār ve münşe’āt (T; GDA) & Ms.or.oct. 2160 \\
\hline 178. & 12.09.1925 & Dīvān, Dülgerzāde Mușțafā Rıżā (T; 13/2, 323) & Ms.or.quart. 1424 \\
\hline 179. & 12.09.1925 & Dīvān, 'Abdürrezzāḳ Nevres (T; 13/2, 411) & Ms.or.quart. 1446 \\
\hline 180. & 12.09 .1925 & Dīvān, Kāsım-1 Envār (F; 14/1, 207) & Ms.or.oct. 2150 \\
\hline 181. & 12.09.1925 & $\begin{array}{l}\text { 1. Beyān-l maktel-i İmām Hüseyn ve Āl-i Resūl șallallāhu 'aleyhi } \\
\text { ve sellem }(\mathrm{T} ; 13 / 4,506) \\
\text { 2. Mi rāc-ı Hażret-i Resūlullāh șallallāhu 'aleyhi ve sellem }(\mathrm{T} ; \\
13 / 4,507)\end{array}$ & Ms.or.oct. 2204 \\
\hline 182. & 12.09 .1925 & Dīvān, Mușțafā Müştāḳ (T; 13/2, 389) & Ms.or.quart. 1499 \\
\hline 183. & 12.09 .1925 & Dīvān, Şeyh İbrāhīm-i Aḳsarāyī (T; 13/2, 368) & Ms.or.quart. 1444 \\
\hline 184. & 12.09 .1925 & Dìvān, Kāā'imī (T; 13/2, 417) & Ms.or.quart. 1493 \\
\hline 185. & 12.09.1925 & Hüsrev ü Şìrìn, Şeyhī $(\mathrm{T} ; 13 / 2,535)$ & Ms.or.oct. 2111 \\
\hline 186. & 12.09.1925 & $\begin{array}{l}\text { 1. Kitābu’t-Tecvīd }(\mathrm{T} ; 13 / 4,20) \\
\text { 2. Risāle fì ḥalli müşsilāt, Mollā Sa } \overline{1} \mathrm{~d}(\mathrm{~T} ; 13 / 4,47)\end{array}$ & Ms.or.oct. 2159 \\
\hline 187. & 12.09.1925 & $\begin{array}{l}\text { 1. Beng ü Bāde, Fużūlī (T; 13/2, 573) } \\
\text { 2. Mektūb, Fużūlī (T; 13/4, 279) } \\
\text { 3. Mecmū'a-i eş 'ār (T; 13/2, 290) }\end{array}$ & Ms.or.quart. 1423 \\
\hline 188. & 12.09 .1925 & Dìvān, Necātī (T; 13/2, 405) & Ms.or.oct. 2117 \\
\hline 189. & 12.09 .1925 & Dìvān, Nābī (T; 13/2, 393) & Ms.or.fol. 3402 \\
\hline 190. & 12.09.1925 & Muḥammediye, Yazıcıoġlı Meḥmed Efendi (T; 13/2, 12) & Ms.or.quart. 1442 \\
\hline
\end{tabular}


The Manuscripts Rescher Sold to the Berlin State Library (Reşer'in Berlin Devlet Kütüphanesi'ne Sattığı Yazmalar)

\begin{tabular}{|c|c|c|c|}
\hline Nr. & $\begin{array}{l}\text { Date } \\
\text { Tarih }\end{array}$ & $\begin{array}{c}\text { Name of Work, Name of Author (Language; Catalogue } \\
\text { Information) } \\
\text { Eser adı, Müellif adı (Dil; Katalog Bilgisi) }\end{array}$ & $\begin{array}{l}\text { Shelf nr. } \\
\text { Raf nr. }\end{array}$ \\
\hline 191. & 12.09 .1925 & Dīvān, Muhịịtị (T; 13/2, 267) & Ms.or.oct. 2149 \\
\hline 192. & 12.09 .1925 & Dìvān, İbrāhīm Tā'ib $(\mathrm{T} ; 13 / 2,461)$ & Ms.or.oct. 2171 \\
\hline 193. & 12.09 .1925 & $\begin{array}{c}\text { S̄ābit: } \\
\text { 1. Dìvān }(\mathrm{T} ; 13 / 2,459) \\
\text { 2. Berber-nāme }(\mathrm{T} ; 13 / 2,541) \\
\text { 3. Hikāye-i Hoca Fesād }(\mathrm{T} ; 13 / 2,549) \\
\text { 4. 'Amr-i Leys }(\mathrm{T} ; 13 / 2,538)\end{array}$ & Ms.or.oct. 2199 \\
\hline 194. & 12.09.1925 & $\begin{array}{c}\text { Sāābit: } \\
\text { 1. Dīvān }(\mathrm{T} ; 13 / 2,458) \\
\text { 2. Edhem ü Hümā }(\mathrm{T} ; 13 / 2,546) \\
\text { 3. Zafer-nāme }(\mathrm{T} ; 13 / 2,553) \\
\text { 4. 'Amr-i Leys }(\mathrm{T} ; 13 / 2,537) \\
\text { 5. Berber-nāme }(\mathrm{T} ; 13 / 2,540) \\
\text { 6. Hikāye-i Hoca Fesād }(\mathrm{T} ; 13 / 2,548)\end{array}$ & Ms.or.oct. 2152 \\
\hline 195. & 12.09 .1925 & Hüsn ü 'Aşk, Şeyh Ġālib (T; 13/2, 514) & Ms.or.quart. 1447 \\
\hline 196. & 12.09 .1925 & Hātime-i misāhat $(\mathrm{T} ; 13 / 5,175)$ & Ms.or.quart. 1436 \\
\hline 197. & 12.09 .1925 & Fetāvā-yı 'Alì Efendi, Çatalcalı 'Alī Efendi (T; 13/5, 110) & Ms.or.quart. 1452 \\
\hline 198. & 12.09 .1925 & Dīvān, Meḥmed Rāşid (T; 13/2, 427) & Ms.or.oct. 2162 \\
\hline 199. & 12.09 .1925 & $\begin{array}{l}\text { el-Kașìdetü't-Tã'iye fì menāzili'l- 'ışk ve 'l-mehabbe, 'Ömer b. } \\
\text { 'Alī İbn el-Fārıż (F; 14/1, 179) }\end{array}$ & Ms.or.oct. 2180 \\
\hline 200. & 12.09.1925 & $\begin{array}{c}\text { Kitābu'n-Nehci'l-meslūk fì siyāseti'l-mülūk, Meḥmed Emīn } \\
\text { Nahịifî (T; 13/2, 220) }\end{array}$ & Ms.or.oct. 2107 \\
\hline 201. & 12.09 .1925 & Dīvān, Riyāżì-i Semerḳandī (F; KOHD) & Ms.or.quart. 1413 \\
\hline 202. & 12.09 .1925 & Dìvān, Aḥmed Paşa (T; 13/2, 307) & Ms.or.oct. 2127 \\
\hline 203. & 12.09 .1925 & Ravżatü’n-na '̄m $(\mathrm{T} ; 13 / 2,134)$ & Ms.or.oct. 2123 \\
\hline 204. & 12.09.1925 & Dìvān, Kāfzāde Fā'iżīi (T; 13/2, 325) & Ms.or.oct. 2125 \\
\hline 205. & 12.09 .1925 & Dìvān, Țālib (T; 13/2, 462) & Ms.or.oct. 2104 \\
\hline 206. & 12.09 .1925 & Dīvān, Ebū İsḥāḳzāde Meḥmed 'Ațā'ullāh (T; 13/2, 317) & Ms.or.quart. 1457 \\
\hline 207. & 12.09 .1925 & $\begin{array}{l}\text { Bekr eș-Ṣıddīḳ b. 'Oșmān: } \\
\text { 1. Şehrī Aḥmed Rāmis'in icāzeti [Ijazat of Şehrī Aḥmed Rāmis] } \\
\text { (A; UC) } \\
\text { 2. Şehrī Aḥmed Rāmis'in icāzeti [Ijazat of Şehrī Aḥmed Rāmis] } \\
\text { (A; UC) }\end{array}$ & Ms.or.quart. 1456 \\
\hline 208. & 12.09 .1925 & Mecmū'a-i eş 'ār $(\mathrm{T} ; 13 / 2,291)$ & Ms.or.quart. 1469 \\
\hline 209. & 12.09 .1925 & Dīvān, Aḳovalızāde Aḥmed Ḩātem (T; 13/2, 364) & Ms.or.quart. 1439 \\
\hline 210. & 12.09 .1925 & Dìvān, Seyfī-i Buhārī (F; KOHD) & Ms.or.quart. 1428 \\
\hline 211. & 12.09 .1925 & Şerḥ-i Şebistān-ı hayāal, Muṣliḥeddīn Mușțafā Surūrī (T; 13/2, & Ms.or.quart. 1448 \\
\hline
\end{tabular}


The Manuscripts Rescher Sold to the Berlin State Library (Reşer'in Berlin Devlet Kütüphanesi'ne Sattığı Yazmalar)

\begin{tabular}{|c|c|c|c|}
\hline Nr. & $\begin{array}{l}\text { Date } \\
\text { Tarih }\end{array}$ & $\begin{array}{c}\text { Name of Work, Name of Author (Language; Catalogue } \\
\text { Information) } \\
\text { Eser adı, Müellif adı (Dil; Katalog Bilgisi) }\end{array}$ & $\begin{array}{l}\text { Shelf nr. } \\
\text { Raf nr. }\end{array}$ \\
\hline 212. & 12.09 .1925 & $\begin{array}{l}\text { el-İżāh fì 'ilmi’l-belāg̀a ve tevābi 'ihā, Muhammed b. } \\
\text { 'Abdurraḥmān el-Kazvīn̄̄ (A; KOHD) }\end{array}$ & Ms.or.quart. 1450 \\
\hline 213. & 12.09 .1925 & $\begin{array}{c}\text { Cāmi ‘ü'l-envār fì menāḳbi’l-ahyār, Șafā'eddīn 'Īsā b. Mūsā el- } \\
\text { Bendenīcī (A; KOHD) }\end{array}$ & Ms.or.quart. 1395 \\
\hline 214. & 12.09 .1925 & $\begin{array}{c}\text { Fütūhu'l-mücāhidīn li-tervīhi ḳulūbi'l-müşāhidīn, Lāmi í Çelebi } \\
\text { (T; 13/4, 140) }\end{array}$ & Ms.or.quart. 1396 \\
\hline 215. & 12.09 .1925 & $\begin{array}{l}\text { 1. Muhtelifü'r-rivāye, Ebu'l-Leys es-Semerḳandī (A; KOHD) } \\
\text { 2. Şerhüu'l-Manz̄umeti'n-Nesefiye (A; KOHD) }\end{array}$ & Ms.or.fol. 3346 \\
\hline 216. & 12.09 .1925 & $\begin{array}{c}\text { el-Yenābì fì ma rifeti’l-ușūl ve't-tefārī', Maḥmūd b. Ramażān } \\
\text { er-Rūmī (A; KOHD) }\end{array}$ & Ms.or.quart. 1404 \\
\hline 217. & 12.09 .1925 & Vakfiye, Ya ḳūb Ag̀a b. 'Abdurraḥmān (T; 13/4, 104) & Ms.or.oct. 2173 \\
\hline 218. & 12.09 .1925 & Münşe 'āt, Ġanīzāde Meḥmed Nādirī (T; 13/4, 291) & Ms.or.oct. 2122 \\
\hline 219. & 12.09 .1925 & Fetāvā, Feyżullāh Efendi (T; 13/4, 86) & Ms.or.quart. 1403 \\
\hline 220. & 12.09 .1925 & $\begin{array}{l}\text { 1. Mecmū 'atü mesā'il fi'l-fikhi'l-Hanefì, Mü'eyyedzāde } \\
\text { 'Abdurraḥmān Efendi (A; KOHD) } \\
\text { 2. el-Muhịtüu'l-Burhānī fi'l-fikhi'n-Nu 'mān̄, Burhāneddīn } \\
\text { Maḥmūd b. Aḥmed İbn Māze (A; KOHD) } \\
\text { 1a-4a, 9b, 10, 12a, 179a, 180b, 185b-89a, 192b-97a: Arapça ve } \\
\text { Türkçe muhtelif metinler [Various texts in Arabic and Turkish] }\end{array}$ & Ms.or.oct. 2139 \\
\hline 221. & 12.09 .1925 & Terceme-i Cāvidān-ı Ḩudā, Dervīş Murtażā (T; 13/1, 338) & Ms.or.quart. 1414 \\
\hline 222. & 12.09 .1925 & Dìvān, Arpaemīnizāde Sāmī (T; 13/2, 442) & Ms.or.oct. 2138 \\
\hline 223. & 12.09 .1925 & Risāle fì vahdeti'l-vücūd, Gelenbevī İsmā '̄il Efendi (A; KOHD) & Ms.or.oct. 2119 \\
\hline 224. & 12.09 .1925 & $\begin{array}{c}\text { Cebir ve geometri hakkında risale [Treatise on algebra and } \\
\text { geometry], Gelenbevī İsmā îl Efendi }(\mathrm{T} ; 13 / 4,351)\end{array}$ & Ms.or.quart. 1418 \\
\hline 225. & 12.09 .1925 & $\begin{array}{l}\text { 1. Kitāb-ı Müselleș, Meḥmed b. Bedreddīn el-Aḳhiṣāiñ (F-T; } \\
\text { KOHD) } \\
\text { 2. Cināsü'l-cinās (F-T; KOHD) }\end{array}$ & Ms.or.oct. 2190 \\
\hline 226. & 12.09 .1925 & Meftūḥ, İbrāhīm Kāmī (T; 13/5, 174) & Ms.or.quart. 1441 \\
\hline 227. & 12.09 .1925 & Enfesü'l-cevāhir, Ebu'l-Fażl Mūsā İzniḳ̄i (T; 13/3, 3) & Ms.or.fol. 3371 \\
\hline 228. & 12.09 .1925 & $\begin{array}{l}\text { 1. Dīvān, Selmān-1 Sāvecī (F; KOHD) } \\
\text { 2. Dìvān, Hูāācū-yı Kirmānī (F; KOHD) }\end{array}$ & Ms.or.quart. 1426 \\
\hline 229. & 12.09 .1925 & Terceme-i Şevāhidü'n-nübüvve, Lāmi 'ì Çelebi $(\mathrm{T} ; 13 / 5,16)$ & Ms.or.fol. 3366 \\
\hline 230. & 26.09 .1925 & $\begin{array}{c}\text { Zikrü 'alāmāti'l-ceyyid mine's-süyūf ve mekādīrihā ve cevherihā } \\
\text { ve ba 'ḍ mā zekerethü'l-hind ve gayruhum (A; KOHD) }\end{array}$ & Ms.or.oct. 2101 \\
\hline 231. & 26.09 .1925 & Tevārīh-i Āl-i 'Ossmān $(\mathrm{T} ; 13 / 1,140)$ & Ms.or.quart. 1437 \\
\hline 232. & 26.09 .1925 & Münāzara-i țūṭ̂̀ vü zāğ, Nev'ī (T; 13/2, 228) & Ms.or.oct. 2121 \\
\hline 233. & 04.10 .1925 & Tuhfe-i emsāal, Meḥmed Nālī (T; 13/2, 525) & Ms.or.oct. 2096 \\
\hline 234. & 04.10 .1925 & Tabșıra, 'Ākif Paşa (T; 13/4, 226) & Ms.or.oct. 2097 \\
\hline
\end{tabular}


The Manuscripts Rescher Sold to the Berlin State Library (Reşer'in Berlin Devlet Kütüphanesi'ne Sattığı Yazmalar)

\begin{tabular}{|c|c|c|c|}
\hline Nr. & $\begin{array}{l}\text { Date } \\
\text { Tarih }\end{array}$ & $\begin{array}{c}\text { Name of Work, Name of Author (Language; Catalogue } \\
\text { Information) } \\
\text { Eser adı, Müellif adı (Dil; Katalog Bilgisi) }\end{array}$ & $\begin{array}{l}\text { Shelf nr. } \\
\text { Raf nr. }\end{array}$ \\
\hline 235. & 04.10 .1925 & Burhānü'l-mu 'cizāt, Hoca İsḥāḳ Efendi (T; 13/4, 218) & Ms.or.oct. 2098 \\
\hline 236. & 04.10 .1925 & İlm-i hạāl (T; 13/5, 38) & Ms.or.quart. 1458 \\
\hline 237. & 20.10 .1925 & 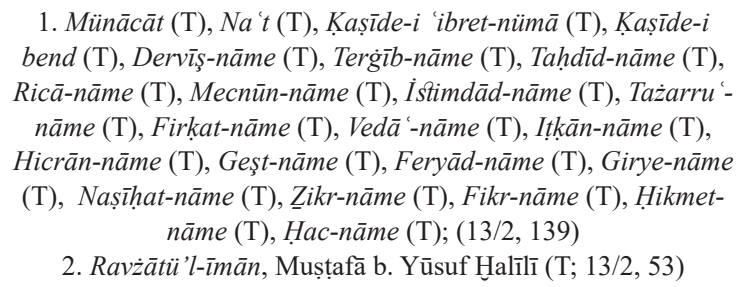 & Ms.or.oct. 2141 \\
\hline 238. & 20.10 .1925 & Şefiḳ-nāme, Meḥmed Şefīk Efendi (T; 13/1, 171) & Ms.or.oct. 2129 \\
\hline 239. & 20.10 .1925 & 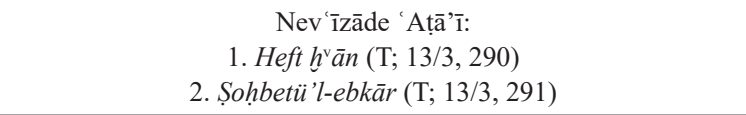 & Ms.or.oct. 2054 \\
\hline 240 . & 20.10 .1925 & 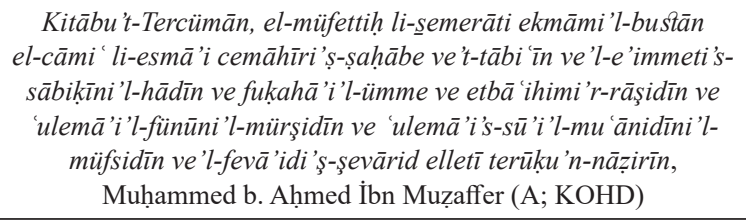 & Ms.or.fol. 3373 \\
\hline 241. & 03.11 .1925 & $\begin{array}{l}\text { Tevfìku'l-muvaffaki'l-hayrāt li-neyli'l-berekāt fì hiżmeti } \\
\text { menba 'i’s-sa 'ādāt, Karadāvūdzāde Meḥmed (T; 13/4, 498) }\end{array}$ & Ms.or.quart. 1460 \\
\hline 242. & 03.11 .1925 & Şerh-i Dìvān-ı Hāâfiz, Muṣliḥeddīn Mușțafā Surūrī (T; 13/5, 263) & Ms.or.fol. 3377 \\
\hline 243. & 07.12 .1925 & $\begin{array}{c}\text { Tercemetü'l-İ lām bi-a 'Tāmi beledillāhi'l-harām, Bāḳī (T; 13/1, } \\
\text { 305) }\end{array}$ & Ms.or.quart. 1409 \\
\hline 244. & 07.12 .1925 & 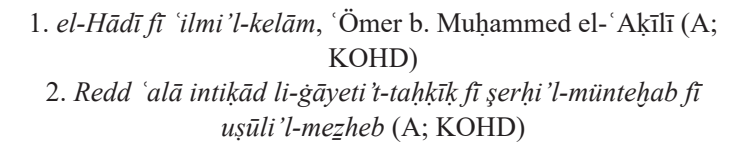 & Ms.or.quart. 1481 \\
\hline 245. & 07.12 .1925 & Tārīh-i Enverī, Sa dullāh Enverī (T; 13/4, 229) & Ms.or.oct. 2069 \\
\hline 246. & 07.12 .1925 & Müri 't-tevārīh , Şam dānīzāde Süleymān (T; 13/1, 43) & Ms.or.fol. 3344 \\
\hline 247. & 07.12 .1925 & 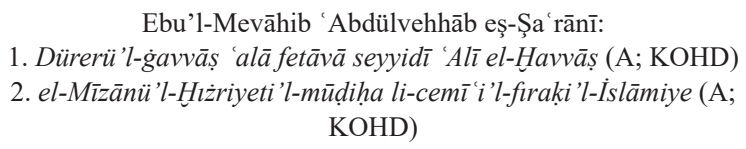 & Ms.or.oct. 2070 \\
\hline 248. & 06.12 .1925 & $\begin{array}{c}\text { Kitābu'n-Nehci'l-meslūk fì siyāseti'l-mülūk, Meḥmed Emīn } \\
\text { Nahịîî (T; 13/2, 219) }\end{array}$ & Ms.or.oct. 2131 \\
\hline
\end{tabular}


The Manuscripts Rescher Sold to the Berlin State Library (Reşer'in Berlin Devlet Kütüphanesi'ne Sattığı Yazmalar)

\begin{tabular}{|c|c|c|c|}
\hline Nr. & $\begin{array}{l}\text { Date } \\
\text { Tarih }\end{array}$ & $\begin{array}{c}\text { Name of Work, Name of Author (Language; Catalogue } \\
\text { Information) } \\
\text { Eser adı, Müellif adı (Dil; Katalog Bilgisi) }\end{array}$ & $\begin{array}{l}\text { Shelf nr. } \\
\text { Raf nr. }\end{array}$ \\
\hline 249. & 06.12 .1925 & $\begin{array}{l}\text { Meḥmed Șādık Erzincānī: } \\
\text { 1. Risāle-i Merḡüb }(\mathrm{T} ; 13 / 2,101) \\
\text { 2. Terbiye-nāme (T; 13/2,159) } \\
\text { 3. Risāle-i Ma rifet-i nefs }(\mathrm{T} ; 13 / 2,99) \\
\text { 4. Risāle-i Maḥbūb }(\mathrm{T} ; 13 / 2,98)\end{array}$ & Ms.or.quart. 1391 \\
\hline 250. & 06.12 .1925 & $\begin{array}{l}\text { 1. Cihad hakkında risale [Treatise on jihad] }(\mathrm{T} ; 13 / 1,21) \\
\text { 2. Tārīh-i Nişāncı, Nişāncızāde Muhyiddīn Meḥmed (T; 13/1, } \\
\text { 386) }\end{array}$ & Ms.or.quart. 1482 \\
\hline 251. & 06.12 .1925 & Nükātü'l-hikem, Süleymān Şeyhī (T; 13/2, 96) & Ms.or.quart. 1402 \\
\hline 252. & 06.12 .1925 & Mị̣net-keşān, Keçecizāde 'İzzet Mollā (T; 13/4, 307) & Ms.or.quart. 1473 \\
\hline 253. & 06.12 .1925 & Netā'icü'l-fünūn ve mehāsinü'l-mütūn, Nev'̄i $(\mathrm{T} ; 13 / 4,4)$ & Ms.or.oct. 2136 \\
\hline 254. & 06.12 .1925 & 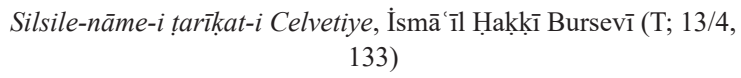 & Ms.or.oct. 2084 \\
\hline 255. & 06.12 .1925 & Bustān-ı ḳuds ve gülistān-ı üns, Nūḥ Efendi (T; 13/4, 497) & Ms.or.quart. 1400 \\
\hline 256. & 06.12 .1925 & Feyż-i feżà'il ve nūr-ı nevāfil, 'Alī Fetḥ̄i Ruscuḳ̄ (T; 13/4, 37) & Ms.or.oct. 2061 \\
\hline 257. & 06.12 .1925 & Tercemetü'ḍ-Darīr ve takdimetü'z-Zahīr, Darīr $(\mathrm{T} ; 13 / 4,210)$ & Ms.or.oct. 2074 \\
\hline 258. & 06.12 .1925 & Sā'at-nāme, Hibetullāh b. İbrāhīm (T; 13/2, 187) & Ms.or.oct. 2126 \\
\hline 259. & 06.12 .1925 & 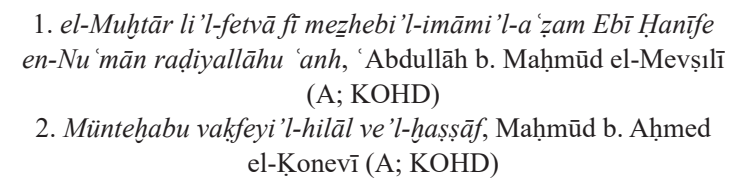 & Ms.or.oct. 2073 \\
\hline 260. & 08.12 .1925 & $\begin{array}{c}\text { el-Cevāhirü'l-vahīde 'ale'd-dürreti'l-ferīde, Muhammed b. } \\
\text { 'Ömer el-Bālī (A; KOHD) }\end{array}$ & Ms.or.quart. 1461 \\
\hline 261. & 08.12 .1925 & 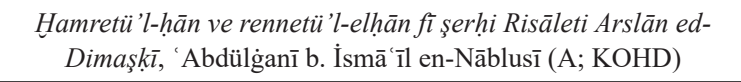 & Ms.or.oct. 2079 \\
\hline 262. & 08.12 .1925 & Dìvān, Z̄ātī (T; 13/2, 481) & Ms.or.oct. 2133 \\
\hline 263. & 08.12 .1925 & Mecmū a 'an ba 'żi’l-fetāvā (A; KOHD) & Ms.or.oct. 2078 \\
\hline 264. & 08.12 .1925 & Ahsenü'l-hadīs, Oḳçızāde Meḥmed Şāhī (T; 13/4, 31) & Ms.or.oct. 2089 \\
\hline 265. & 08.12 .1925 & 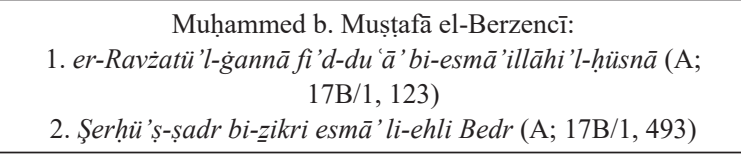 & Ms.or.oct. 2066 \\
\hline 266. & 08.12 .1925 & $\begin{array}{c}\text { 'Azīz Maḥmūd Hüdā'ī: } \\
\text { 1. Risāletü Necāti'l-garīk fi'l-cem 've't-tefrīk }(\mathrm{T} ; 13 / 2,37) \\
\text { 2. Tecelliyāt }(\mathrm{T} ; 13 / 2,162) \\
\text { 3. Tarīkat-nāme }(\mathrm{T} ; 13 / 2,150) \\
\text { 4. Risāle }(\mathrm{T} ; 13 / 2,353)\end{array}$ & Ms.or.quart. 1398 \\
\hline 267. & 08.12 .1925 & $\begin{array}{l}\text { Menāḳıb-ı Seyyid Aḥmed el-Bedevī, Veffāḳ Meḥmed Ḥıf̣̄i (T; } \\
13 / 4,147)\end{array}$ & Ms.or.oct. 2128 \\
\hline
\end{tabular}


The Manuscripts Rescher Sold to the Berlin State Library (Reşer'in Berlin Devlet Kütüphanesi'ne Sattığı Yazmalar)

\begin{tabular}{|c|c|c|c|}
\hline Nr. & $\begin{array}{l}\text { Date } \\
\text { Tarih }\end{array}$ & $\begin{array}{c}\text { Name of Work, Name of Author (Language; Catalogue } \\
\text { Information) } \\
\text { Eser adı, Müellif adı (Dil; Katalog Bilgisi) }\end{array}$ & $\begin{array}{l}\text { Shelf nr. } \\
\text { Raf nr. }\end{array}$ \\
\hline 268. & 08.12 .1925 & 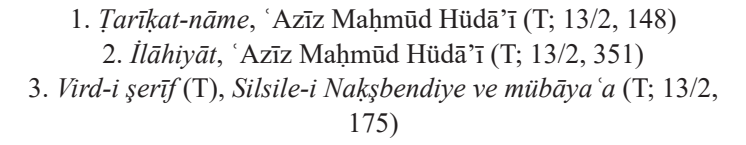 & Ms.or.quart. 1467 \\
\hline 269. & 08.12 .1925 & $\begin{array}{c}\text { Tibru'l-mesbūk fì mā yahtācūne ileyhi'l-mülūk, Kudsī 'Abdullāh } \\
\text { Efendi (T; 13/2, 221) }\end{array}$ & Ms.or.oct. 2071 \\
\hline 270. & 04.01 .1926 & Gül ü Bülbül, Fażlī (T; 13/2, 512) & Ms.or.oct. 2030 \\
\hline 271. & 04.01 .1926 & $\begin{array}{l}\text { 1. Tārīh-i Ṭaberī }(\mathrm{T} ; 13 / 1,5) \\
\text { 2. Delā'il-i nübüvvet-i Muhammedī ve şemā'il-i fütüuvet-i } \\
\text { Aḥmedī, Altıparmaḳ Meḥmed Efendi }(\mathrm{T} ; 13 / 1,68)\end{array}$ & Ms.or.quart. 1387 \\
\hline 272. & 04.01 .1926 & Dìvān, Haşmet (T; 13/2, 360) & Ms.or.quart. 1383 \\
\hline 273. & 04.01 .1926 & Terceme-i Tibyān, Debbāġzāde Meḥmed Efendi (T; 13/4, 12) & Ms.or.quart. 1363 \\
\hline 274. & 04.01 .1926 & Terceme-i Reşehātü 'ayni'l-ḥayāt, Meḥmed Ma rūf (T; 13/3, 191) & Ms.or.fol. 3334 \\
\hline 275. & 04.01 .1926 & Sìretü'n-nebī, Meḥmed (T; 13/3, 277) & Ms.or.fol. 3333 \\
\hline 276. & 18.01.1926 & $\begin{array}{c}\text { Mir'ātü'ṣ-șafā fì ahvāli'l-enbiyā', Karaçelebizāde 'Abdül 'azīz } \\
\text { Efendi }(\mathrm{T} ; 13 / 4,192)\end{array}$ & Ms.or.oct. 1970 \\
\hline 277. & 18.01.1926 & Dīvān, Ṭayyār Maḥmūd Paşa (T; 13/2, 464) & Ms.or.oct. 1928 \\
\hline 278. & 18.01.1926 & Cāmasb-nāme (T; 13/2, 231) & Ms.or.oct. 2047 \\
\hline 279. & 18.01 .1926 & Hizānetü'l-fiḳh, Ebu'l-Leys es-Semerḳandī (A; KOHD) & Ms.or.oct. 2025 \\
\hline 280. & 18.01.1926 & Țūfān-ı ma 'rifet, Neş'et (F; 14/1, 193) & Ms.or.oct. 1991 \\
\hline 281. & 18.01 .1926 & $\begin{array}{c}\text { Terceme-i Minhācü'l- 'ābidīn ilā cenneti rabbi'l- 'älemīn, İlyās } \\
\text { Nihānī }(\mathrm{T} ; 13 / 2,204)\end{array}$ & Ms.or.oct. 2026 \\
\hline 282. & 18.01 .1926 & $\begin{array}{l}\text { et-Tevkīf 'alā mühimmāti tote 'ārīf, Muhammed 'Abdurra'ūf el- } \\
\text { Münāvī (A; KOHD) }\end{array}$ & Ms.or.oct. 1990 \\
\hline 283. & 18.01.1926 & 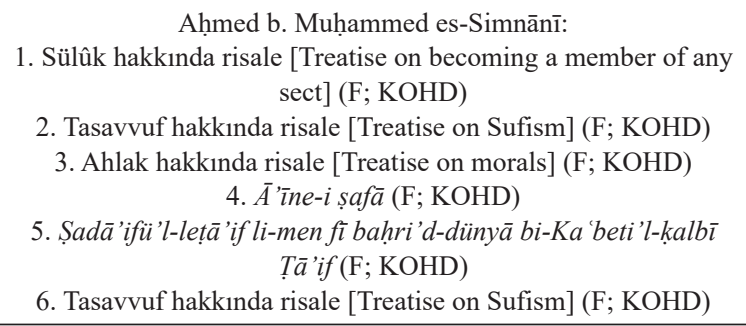 & Ms.or.oct. 2146 \\
\hline 284. & 18.01.1926 & $\begin{array}{c}\text { Şevākilü'l-ḥūr 'alā heyākili’n-nūr, Muhammed b. Es'ad ed- } \\
\text { Devvānī (A; KOHD) }\end{array}$ & Ms.or.oct. 2185 \\
\hline 285. & 18.01.1926 & 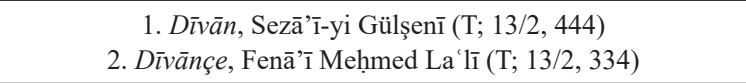 & Ms.or.oct. 2027 \\
\hline 286. & 18.01.1926 & Şerḥü Nazmi'l-Ferā'izì śSirāciye, Muḥsin-i Kayșerī (A; KOHD) & Ms.or.oct. 1927 \\
\hline 287. & 18.01.1926 & Menāsikü'l-ḥacc, Sināneddīn Yūsuf el-Mekkī (T; 13/4, 50) & Ms.or.oct. 1973 \\
\hline
\end{tabular}


The Manuscripts Rescher Sold to the Berlin State Library (Reşer'in Berlin Devlet Kütüphanesi'ne Sattığı Yazmalar)

\begin{tabular}{|c|c|c|c|}
\hline 288. & 18.01 .1926 & Vikāyetü'r-rivāye fì mesā'ili'l-Hidāye $(\mathrm{T} ; 13 / 4,75)$ & Ms.or.oct. 2040 \\
\hline Nr. & $\begin{array}{l}\text { Date } \\
\text { Tarih }\end{array}$ & $\begin{array}{c}\text { Name of Work, Name of Author (Language; Catalogue } \\
\text { Information) } \\
\text { Eser adı, Müellif adı (Dil; Katalog Bilgisi) }\end{array}$ & $\begin{array}{c}\text { Shelf nr. } \\
\text { Raf nr. }\end{array}$ \\
\hline 289. & 18.01.1926 & Nihālistān, Nergisī (T; 13/2, 201) & Ms.or.oct. 2038 \\
\hline 290. & 18.01 .1926 & Şerḥü Şu a abi'l-īmān, İsmā'īl Ḥaḳkịi Bursevī $(T ; 13 / 4,39)$ & Ms.or.oct. 1994 \\
\hline 291. & 18.01 .1926 & Terceme-i Mu 'addilü’ș-șalāt $(\mathrm{T} ; 13 / 3,34)$ & Ms.or.oct. 1979 \\
\hline 292. & 18.01.1926 & Terceme-i Şerhü̈'ş-Şăfiye (T; 13/5, 192) & Ms.or.oct. 1993 \\
\hline 293. & 18.01 .1926 & Cevāhirü'l-aṣdāf $(\mathrm{T} ; 13 / 1,336)$ & Ms.or.quart. 1364 \\
\hline 294. & 18.01.1926 & Ġarībnāme, 'Āşı1k Paşa $(\mathrm{T} ; 13 / 1,364)$ & Ms.or.quart. 1362 \\
\hline 295. & 18.01.1926 & 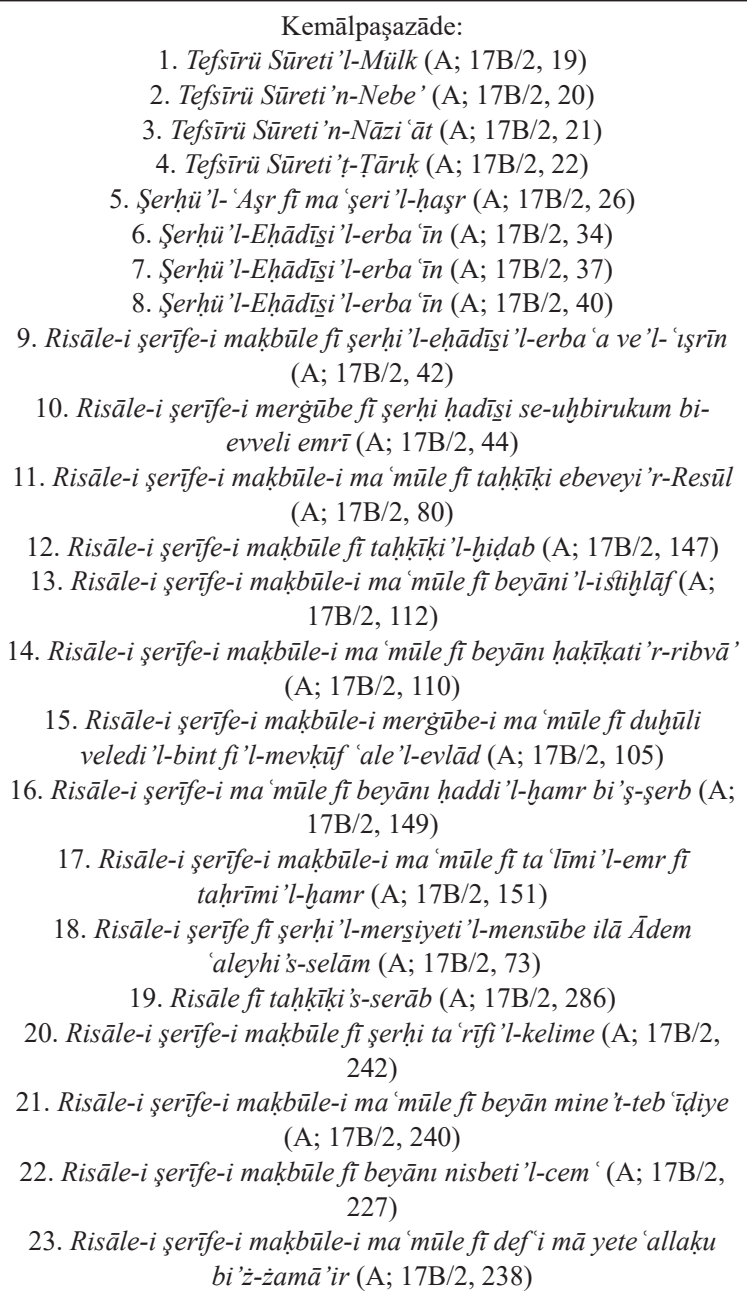 & Ms.or.fol. 3326 \\
\hline
\end{tabular}


The Manuscripts Rescher Sold to the Berlin State Library (Reşer'in Berlin Devlet Kütüphanesi'ne Sattığı Yazmalar)

\begin{tabular}{|c|c|c|c|}
\hline Nr. & $\begin{array}{l}\text { Date } \\
\text { Tarih }\end{array}$ & $\begin{array}{c}\text { Name of Work, Name of Author (Language; Catalogue } \\
\text { Information) } \\
\text { Eser adı, Müellif adı (Dil; Katalog Bilgisi) }\end{array}$ & $\begin{array}{c}\text { Shelf nr. } \\
\text { Raf nr. }\end{array}$ \\
\hline 295. & 18.01 .1926 & 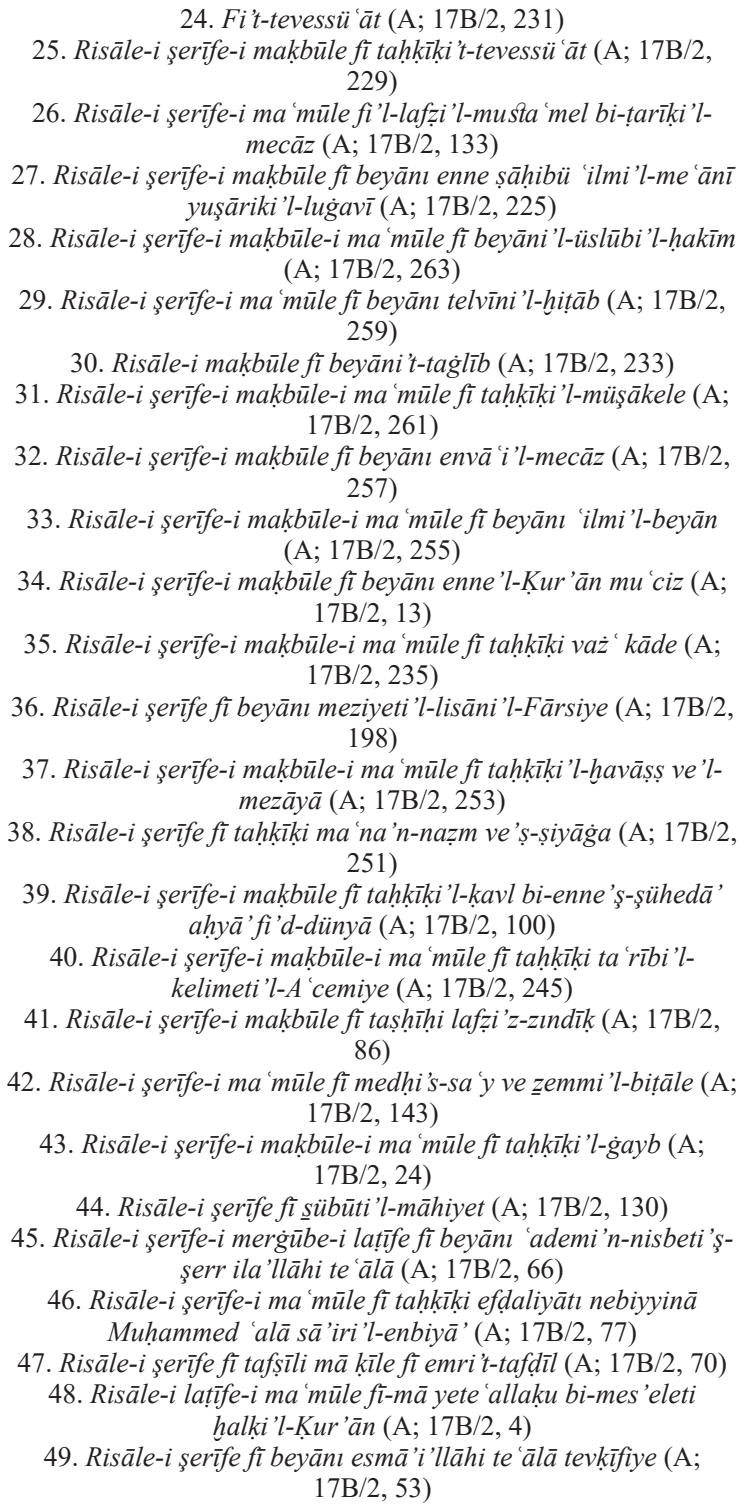 & Ms.or.fol. 3326 \\
\hline
\end{tabular}


The Manuscripts Rescher Sold to the Berlin State Library (Reşer'in Berlin Devlet Kütüphanesi'ne Sattığı Yazmalar)

\begin{tabular}{|c|c|c|c|}
\hline Nr. & $\begin{array}{l}\text { Date } \\
\text { Tarih }\end{array}$ & $\begin{array}{c}\text { Name of Work, Name of Author (Language; Catalogue } \\
\text { Information) } \\
\text { Eser adı, Müellif adı (Dil; Katalog Bilgisi) }\end{array}$ & $\begin{array}{l}\text { Shelf nr. } \\
\text { Raf nr. }\end{array}$ \\
\hline 295. & 18.01.1926 & 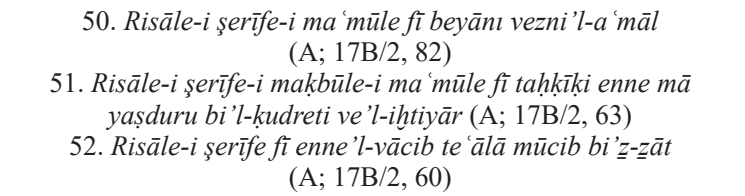 & Ms.or.fol. 3326 \\
\hline 296. & 18.01.1926 & Şerḥ-i Mülteka 'l-ebḥur, Meḥmed Mevḳūâtī $(T ; 13 / 4,66)$ & Ms.or.quart. 1388 \\
\hline 297. & 18.01.1926 & Fetāve'l-Ankaravī, Anḳaravī Meḥmed Emīn Efendi (A; KOHD) & Ms.or.quart. 1361 \\
\hline 298. & 18.01.1926 & Mecelletü'l-mehākim, 'Ākifzāde 'Abdürrahīim Efendi (T; 13/4, & Ms.or.fol. 3395 \\
\hline 299. & 30.01 .1926 & Haḳikat-nāme, Mollā İlāhī (T; 13/3, 60) & Ms.or.quart. 1385 \\
\hline 300. & 30.01 .1926 & $\begin{array}{l}\text { 1. Dīvān, Șābir Pārsā (T; 13/2, 455) } \\
\text { 2. Dīvān, Meḥmed 'İṣmetī (T; 13/2, 372) }\end{array}$ & Ms.or.oct. 2048 \\
\hline 301. & 30.01 .1926 & $\begin{array}{c}\text { Vāḳ 'ātü’l-müftīn, 'Abdülḳādir b. Yūsuf Kạadrī Efendi (A; } \\
\text { KOHD) }\end{array}$ & Ms.or.oct. 1987 \\
\hline 302. & 30.01 .1926 & Ġazavāt-ı Mihālog̀lı 'Alī Beg, Sūzì Çelebi (T; 13/2, 528) & Ms.or.quart. 1468 \\
\hline 303. & 30.01 .1926 & $\begin{array}{c}\text { Terceme-i İbrāhīm-i Halebī Şerhü Münyeti'l-muṣallì, Seyyid 'Alī } \\
\text { b. İbrāhīm }(\mathrm{T} ; 13 / 4,34)\end{array}$ & Ms.or.quart. 1492 \\
\hline 304. & 30.01 .1926 & Dīvān, Hāāız (T; 13/3, 253) & Ms.or.oct. 1986 \\
\hline 305. & 30.01 .1926 & Sākī-nāme, 'Aynī (T; 13/2, 572) & Ms.or.quart. 1370 \\
\hline 306. & 30.01 .1926 & ŞerḥüNevābigì'l-kelim (T; 13/4, 456) & Ms.or.oct. 2039 \\
\hline 307. & 30.01 .1926 & Ahterī kebīr mine'l-luġa, Ahterī (A-T; KOHD) & Ms.or.quart. 1360 \\
\hline 308. & 30.01 .1926 & Tefsīr, Üveys b. Hoca 'Ossmān (T; 13/5, 2) & Ms.or.fol. 3393 \\
\hline 309. & 02.02 .1926 & Kitāb-ı müstakìm $(\mathrm{T} ; 13 / 2,216)$ & Ms.or.quart. 1366 \\
\hline 310. & 02.03 .1926 & 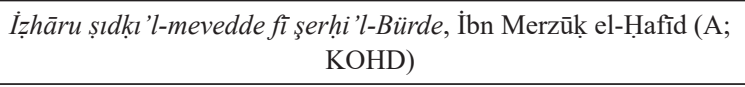 & Ms.or.quart. 1359 \\
\hline 311. & 02.03 .1926 & $\begin{array}{l}\text { Taḥkīk-i vahdet-i vücūda dā'ir bir risāle-i mühimmenüñ } \\
\text { tercemesi, Mūsā Kāẓım (T; GDA) }\end{array}$ & Ms.or.oct. 1933 \\
\hline 312. & 02.03 .1926 & 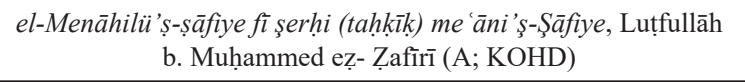 & Ms.or.oct. 1926 \\
\hline 313. & 02.03 .1926 & $\begin{array}{l}\text { Hüsnü t-takvīm, Müstaḳīmzāde Süleymān Sa 'deddīn (T; 13/4, } \\
\text { 425) }\end{array}$ & Ms.or.oct. 1934 \\
\hline 314. & 02.03 .1926 & $\begin{array}{c}\text { 1. Hediyetü'l-kużāt, Halīl Niyāzì (T; 13/3, 103) } \\
\text { 2. Havāṣs (T; 13/3, 210) } \\
\text { 3. Ma 'rūizàt-ı Ebu's-Su'ūd, Ebu's-Su 'ūd Efendi (T; 13/3, 109) }\end{array}$ & Ms.or.oct. 1935 \\
\hline 315. & 02.03 .1926 & Mecmū 'a-i fetāvā, Mūsāzāde 'Abdullāh (T; 13/4, 89) & Ms.or.oct. 2200 \\
\hline 316. & 02.03 .1926 & Şerh-i Gülistān, Şem '̄i (T; 13/2, 631) & Ms.or.oct. 2197 \\
\hline
\end{tabular}


The Manuscripts Rescher Sold to the Berlin State Library (Reşer'in Berlin Devlet Kütüphanesi'ne Sattığı Yazmalar)

\begin{tabular}{|c|c|c|c|}
\hline Nr. & $\begin{array}{l}\text { Date } \\
\text { Tarih }\end{array}$ & $\begin{array}{c}\text { Name of Work, Name of Author (Language; Catalogue } \\
\text { Information) } \\
\text { Eser adı, Müellif adı (Dil; Katalog Bilgisi) }\end{array}$ & $\begin{array}{l}\text { Shelf nr. } \\
\text { Raf nr. }\end{array}$ \\
\hline 317. & 02.03 .1926 & Ferā'iż-i vāfiye, Ḥācibzāde Meḥmed b. Mușțafā (T; 13/4, 63) & Ms.or.oct. 1932 \\
\hline 318. & 02.03 .1926 & Netā'icü'l-fünūn ve mehāsinü'l-mütūn, Nev'̄i (T; GDA) & Ms.or.oct. 1982 \\
\hline 319. & 02.03 .1926 & Șūret-i șukūk, Meḥmed es-S̄ānī (T; GDA) & Ms.or.oct. 1981 \\
\hline 320. & 02.03 .1926 & Fütüvvet-nāme-i kebīr, Meḥmed b. 'Alā'eddīn (T; 13/5, 94) & Ms.or.quart. 1477 \\
\hline 321. & 02.03 .1926 & Kitābu Hermesi'l-Herāmise (T; 13/4, 377) & Ms.or.oct. 1983 \\
\hline 322. & 02.03 .1926 & Dīvān, 'Abdünnāfi' 'İffet (T; 13/2, 369) & Ms.or.quart. 1367 \\
\hline 323. & 02.03 .1926 & $\begin{array}{l}\text { 1. Dìvān, Meḥ̣med Rāşid (T; 13/2, 426) } \\
\text { 2. Eş'ār, Meḥmed Țālib (T; 13/2, 463) }\end{array}$ & Ms.or.oct. 1989 \\
\hline 324. & 02.03 .1926 & $\begin{array}{l}\text { Șadreddīnzāde Şirvānī: } \\
\text { 1. el-Fevā'idü'l-Hākāniyeti'l-Ahmedhāniye (A; KOHD) } \\
\text { 2. Risāle fì tahkīki'l-mebde've'l-me 'àd (A; KOHD) }\end{array}$ & Ms.or.oct. 1988 \\
\hline 325. & 02.03 .1926 & 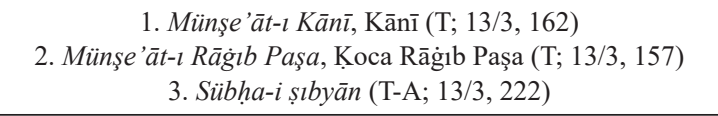 & Ms.or.oct. 1929 \\
\hline 326. & 02.03 .1926 & Tezzkiretü'ş-şu 'arāa, Sālim (T; 13/1, 267) & Ms.or.quart. 1357 \\
\hline 327. & 02.03 .1926 & $\begin{array}{l}\text { Nābī: } \\
\text { 1. Terceme-i Hadīs-i erba īn }(\mathrm{T} ; 13 / 1,339) \\
\text { 2. Tārīh-i feth-i Kamaniçe }(\mathrm{T} ; 13 / 1,167) \\
\text { 3. Tuhfetü'l-Haremeyn }(\mathrm{T} ; 13 / 1,316)\end{array}$ & Ms.or.fol. 3399 \\
\hline 328. & 02.03 .1926 & Dìvān, 'Ārif Süleymān (T; 13/2, 312) & Ms.or.oct. 1975 \\
\hline 329. & 02.03 .1926 & Şerh-i Bahāristān, Şem '̄i (T; 13/2, 627) & Ms.or.oct. 1976 \\
\hline 330. & 02.03 .1926 & 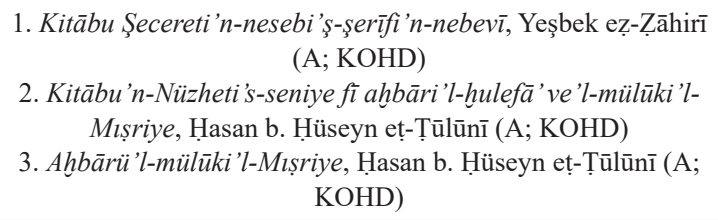 & Ms.or.fol. 3398 \\
\hline 331. & 02.03 .1926 & Mecmū'a-i nizāmmāt (T; GDA) & Ms.or.oct. 2194 \\
\hline 332. & 02.03 .1926 & Münşe'āt, Nābī (T; 13/4, 288) & Ms.or.oct. 1962 \\
\hline 333. & 02.03 .1926 & $\begin{array}{l}\text { 1. Dìvān, Kāşif Sa 'deddīn (T; 13/2, 381) } \\
\text { 2. Dīvān, Meḥmed 'İșmetī (T; 13/2, 371) }\end{array}$ & Ms.or.oct. 2155 \\
\hline 334. & 02.03 .1926 & $\begin{array}{l}\text { Vāḳ ‘ātü’l-müftīn, 'Abdülḳādir b. Yūsuf Kadrī Efendi (A; } \\
\text { KOHD) }\end{array}$ & Ms.or.quart. 1369 \\
\hline 335. & 02.03 .1926 & Sā'at-nāme, Hibetullāh b. İbrāhīm (T; 13/2, 188) & Ms.or.oct. 1960 \\
\hline 336. & 02.03 .1926 & $\begin{array}{l}\text { 1. Risāle fì elfāza küfr }(\mathrm{T} ; 13 / 3,44) \\
\text { 2. Risāle-i Nikāh }(\mathrm{T} ; 13 / 3,107)\end{array}$ & Ms.or.oct. 1959 \\
\hline 337. & 02.03 .1926 & Bahrü'l-garā'ib, Luțfullāh Ḥalīmī (F-T; 13/5, 198) & Ms.or.quart. 1484 \\
\hline
\end{tabular}


The Manuscripts Rescher Sold to the Berlin State Library (Reşer'in Berlin Devlet Kütüphanesi'ne Sattığı Yazmalar)

\begin{tabular}{|c|c|c|c|}
\hline Nr. & $\begin{array}{l}\text { Date } \\
\text { Tarih }\end{array}$ & $\begin{array}{c}\text { Name of Work, Name of Author (Language; Catalogue } \\
\text { Information) } \\
\text { Eser adı, Müellif adı (Dil; Katalog Bilgisi) }\end{array}$ & $\begin{array}{l}\text { Shelf nr. } \\
\text { Raf nr. }\end{array}$ \\
\hline 338. & 02.03 .1926 & 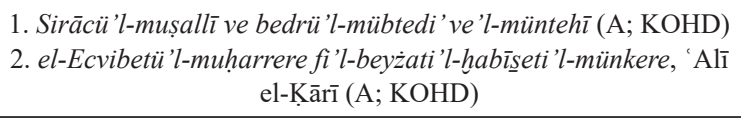 & Ms.or.oct. 2148 \\
\hline 339. & 02.03 .1926 & $\begin{array}{l}\text { 1. Hadīkatü'l-üdebā', Halīl b. 'Alī (A; KOHD) } \\
\text { 2. el-Kașīdetü'n-Nu 'māniye, Nu mān b. SSābit (A; KOHD) }\end{array}$ & Ms.or.oct. 1958 \\
\hline 340. & 02.03.1926 & Mevlid-i şerīf-i Hadīcetü’l-kübrāa $(\mathrm{T} ; 13 / 4,505)$ & Ms.or.oct. 1957 \\
\hline 341. & 02.03 .1926 & Nuhbetü'l-esrār, Halīl Hüdā'ī (T; 13/4, 38) & Ms.or.oct. 2147 \\
\hline 342. & 02.03 .1926 & 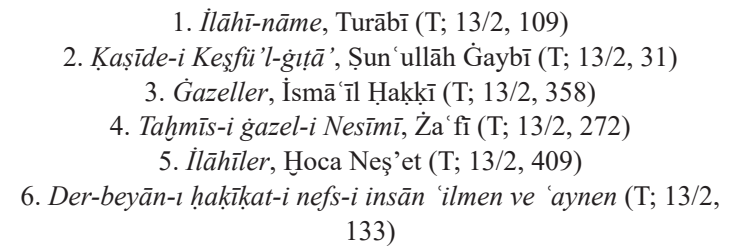 & Ms.or.oct. 2154 \\
\hline 343. & 02.03 .1926 & $\begin{array}{l}\text { 1. Necātü'l-muṣallīni’l-ḩāşi 'ìn, 'Abdurraḥmān eḍ-Darīr (T; 13/3, } \\
\text { 50) } \\
\text { 2. Terceme-i Mu 'addilü'ṣ-ṣalāt }(\mathrm{T} ; 13 / 3,35)\end{array}$ & Ms.or.oct. 1961 \\
\hline 344. & 02.03 .1926 & Dīvān, Faṣị̣ Aḥmed Dede (T; 13/2, 327) & Ms.or.quart. 1356 \\
\hline 345. & 02.03 .1926 & Düstūrü'l- 'amel, Riyāżī (T; 13/4, 445) & Ms.or.oct. 1952 \\
\hline 346. & 02.03 .1926 & 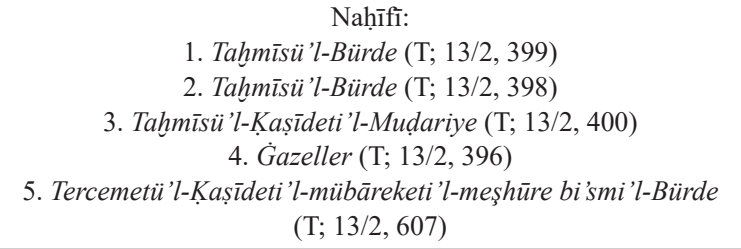 & Ms.or.oct. 1951 \\
\hline 347. & 02.03 .1926 & $\begin{array}{l}\text { 1. Gencīne-i rāz, Dukākīnzāde Yahyyā (T; 13/2, 210) } \\
\text { 2. Dīvān, 'Alī b. Meḥmed Riżà'̄i (T; 13/2, 433) }\end{array}$ & Ms.or.oct. 1950 \\
\hline 348. & 02.03 .1926 & Enfesü'l-cevāhir, Mūsā İznīḳī (T; 13/3, 2, 4, 6) 3 c. & Ms.or.quart. 1472 \\
\hline 349. & 02.03 .1926 & $\begin{array}{c}\text { Hāşsiye 'alā Şerhi'l-'Akāàidi'n-Nesefiye, Ahmed b. Mūsā el- } \\
\text { Hayālī (A; KOHD) }\end{array}$ & Ms.or.oct. 1995 \\
\hline 350. & 02.03 .1926 & $\begin{array}{l}\text { Hāşsiye 'alā Hāsşiyeti'l-Lārī, Muhammed b. Humeyd el-Kefevī } \\
\text { (A; KOHD) }\end{array}$ & Ms.or.quart. 1474 \\
\hline 351. & 02.03 .1926 & Hüsrev ü Şı̄rīn, Şeyhī (T; 13/2, 533) & Ms.or.oct. 1972 \\
\hline 352. & 02.03 .1926 & 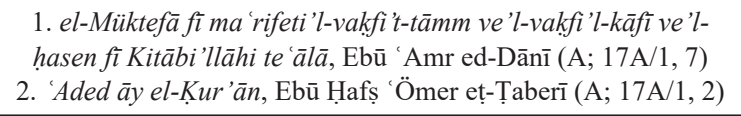 & Ms.or.quart. 1386 \\
\hline 353. & 02.03 .1926 & Hāşsiye 'alā şerḥi Tașrīfì'l- 'İzzī, Dede Cöngī (A; KOHD) & Ms.or.oct. 2202 \\
\hline 354. & 02.03 .1926 & $\begin{array}{c}\text { Mețāli 'ü’l-enz̧ār fi şerhi Ṭevāli i'l-envār, Maḥmūd b. } \\
\text { 'Abdurraḥmān el-Ișfahānī (A; KOHD) }\end{array}$ & Ms.or.oct. 1980 \\
\hline
\end{tabular}


The Manuscripts Rescher Sold to the Berlin State Library (Reşer'in Berlin Devlet Kütüphanesi'ne Sattığı Yazmalar)

\begin{tabular}{|c|c|c|c|}
\hline Nr. & $\begin{array}{l}\text { Date } \\
\text { Tarih }\end{array}$ & $\begin{array}{c}\text { Name of Work, Name of Author (Language; Catalogue } \\
\text { Information) } \\
\text { Eser adı, Müellif adı (Dil; Katalog Bilgisi) }\end{array}$ & $\begin{array}{l}\text { Shelf nr. } \\
\text { Raf nr. }\end{array}$ \\
\hline 355. & 02.03 .1926 & Ferā'iż-i vāfiye, Hāācibzāde Meḥmed b. Muṣtafā (T; 13/4, 64) & Ms.or.oct. 1978 \\
\hline 356. & 02.03 .1926 & $\begin{array}{c}\text { Muhtașaru Ġunyeti’l-mütemellī fì şerhi Münyeti'l-mușallī, } \\
\text { İbrāhīm b. Muḥammed el-Ḥalebī (A; KOHD) }\end{array}$ & Ms.or.oct. 2188 \\
\hline 357. & 02.03 .1926 & 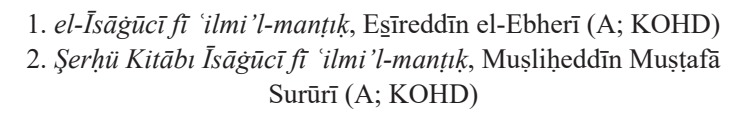 & Ms.or.oct. 1992 \\
\hline 358. & 02.03 .1926 & 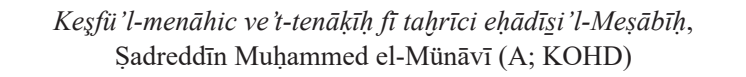 & Ms.or.fol. 3394 \\
\hline 359. & 02.03.1926 & 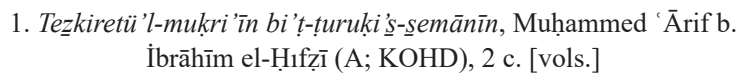 & Ms.or.oct. 2192 \\
\hline 360. & 05.06 .1926 & $\begin{array}{c}\text { Terceme-i Ġazeliyāt-ı Șā'ib, Ebū Bekr Nuṣret Efendi (T; 13/5, } \\
\text { 269) }\end{array}$ & Ms.or.fol. 4080 \\
\hline 361. & 05.06 .1926 & $\begin{array}{l}\text { Zarīfì: } \\
\text { 1. Rāhatü'l-ervāh }(\mathrm{T} ; 13 / 2,212) \\
\text { 2. Mihr ü Māh }(\mathrm{T} ; 13 / 2,561)\end{array}$ & Ms.or.oct. 2390 \\
\hline 362. & 05.06 .1926 & $\begin{array}{c}\text { Mebāriḳu'l-ezhār fì şerhi Meşāriḳı'l-envār, 'Abdüllațīf İbn } \\
\text { Melek (A; KOHD) }\end{array}$ & Ms.or.quart. 1537 \\
\hline 363. & 05.06 .1926 & Kusșatu 'Anter (T; 13/3, 313) & Ms.or.fol. 4079 \\
\hline 364. & 05.06 .1926 & $\begin{array}{l}\text { Şerḥü'd-Dürreti'l-muḍī'a fì kırāà'āti'l-e 'imme es-selāseti'l- } \\
\text { marḍiye, Ebu'l-Kāāsım Muhammed en-Nüveyrī (A; KOHD) }\end{array}$ & Ms.or.oct. 2304 \\
\hline 365. & 05.06 .1926 & Cāmi '̈̈’n-neșāyih, Hüseynī b. Aḥmed-i Sirozī $(\mathrm{T} ; 13 / 2,8)$ & Ms.or.oct. 2320 \\
\hline 366. & 05.06 .1926 & Şemsiye, Yazıcı Sālih (T; 13/1, 393) & Ms.or.quart. 1573 \\
\hline 367. & 05.06 .1926 & 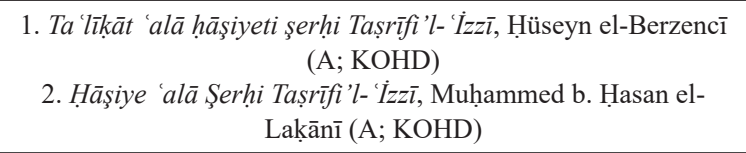 & Ms.or.quart. 1534 \\
\hline 368. & 05.06 .1926 & $\begin{array}{l}\text { 1. el-Hāadim fì ḩalli elfāzzı Ebi'l-Kāsim, 'Abdurraḥmān b. } \\
\text { 'Abdullāh el-Cüllī (A; KOHD) } \\
\text { 2. er-Risāletü'l-müsemmā bi-Şerḥi'l-vaż' (A; KOHD) } \\
\text { 3. el-Kitābu'l-müsemmā bi-Şerḥi'l-isti'āre (A; KOHD) }\end{array}$ & Ms.or.quart. 1542 \\
\hline 369. & 05.06 .1926 & $\begin{array}{l}\text { Abdullāh Șalāḥī 'Uşşāḳ̄i: } \\
\text { 1. Cevher-i tāc-l hilāafet (T; 13/2, 103) } \\
\text { 2. Şerḥ-i ġazel-i Mișrī (T; 13/2, 646) }\end{array}$ & Ms.or.quart. 1532 \\
\hline 370. & 05.06 .1926 & $\begin{array}{c}\text { el-Vakf ve'l-ibtidā', Muhammed b. Ṭayfūr es-Secāvendī (A-F; } \\
\text { KOHD) }\end{array}$ & Ms.or.quart. 1538 \\
\hline 371. & 05.06 .1926 & Kitāb fì 'ilmi'l-muḥậ̣arāt, Maḥmūd b. Muhammed (A; KOHD) & Ms.or.oct. 2395 \\
\hline
\end{tabular}


The Manuscripts Rescher Sold to the Berlin State Library (Reşer'in Berlin Devlet

Kütüphanesi'ne Sattığı Yazmalar)

\begin{tabular}{|c|c|c|c|}
\hline Nr. & $\begin{array}{l}\text { Date } \\
\text { Tarih }\end{array}$ & $\begin{array}{c}\text { Name of Work, Name of Author (Language; Catalogue } \\
\text { Information) } \\
\text { Eser adı, Müellif adı (Dil; Katalog Bilgisi) }\end{array}$ & $\begin{array}{l}\text { Shelf nr. } \\
\text { Raf nr. }\end{array}$ \\
\hline 372. & 05.06.1926 & 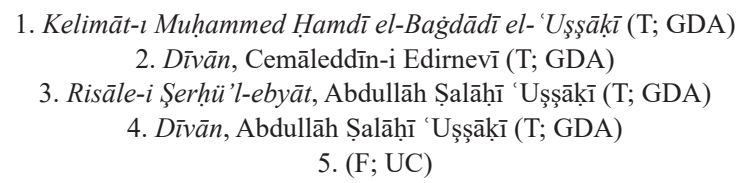 & Ms.or.oct. 2287 \\
\hline 373. & 05.06 .1926 & Kitābu'n-Necāt, İsmā' ̄il Ḥaḳkī Bursevī (T; 13/2, 46) & Ms.or.oct. 2339 \\
\hline 374. & 05.06.1926 & Havżu'l-hayāt $(\mathrm{T} ; 13 / 5,58)$ & Ms.or.fol. 4112 \\
\hline 375. & 05.06.1926 & Feżà'ilü'l-cihād, Bāḳī (T; 13/1, 385) & Ms.or.quart. 1569 \\
\hline 376. & 05.06 .1926 & 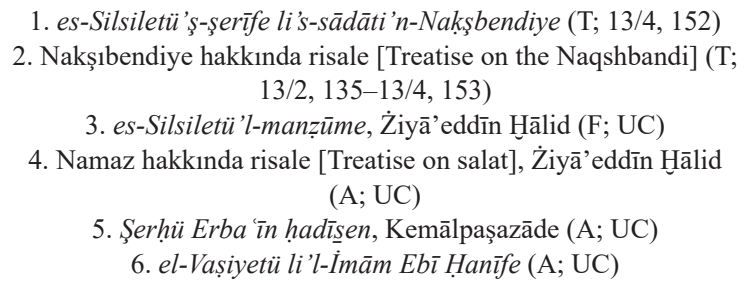 & Ms.or.oct. 2338 \\
\hline 377. & 05.06 .1926 & Şerḥü Ebyāti’l-Cāmī (A; KOHD) & Ms.or.oct. 2392 \\
\hline 378. & 05.06 .1926 & Mecmū 'a-i eş 'ār, Meḥmed Şerīfī (T; 13/2, 288) & Ms.or.oct. 2216 \\
\hline 379. & 05.06 .1926 & $\begin{array}{l}\text { 1. Zübdetü'l- 'irfān fì vücūhi'l-Ķur'ān, Ḥāmid İbn 'Abdülfettāḥ } \\
\text { el-Pāluvī (A; KOHD) } \\
\text { 2. [Bāb] Vakf Hamza ve Hişām (A; KOHD) } \\
\text { 3. Risāle fì tecvīdi'l-Kur'ān (A; KOHD) }\end{array}$ & Ms.or.quart. 1524 \\
\hline 380. & 05.06.1926 & Şerḥü’l-Viḳāye, 'Abdüllațīf İbn Melek (A; KOHD) & Ms.or.fol. 4076 \\
\hline 381. & 05.06 .1926 & $\begin{array}{c}\text { Fetāvā Kadrī Efendi el-merhūm, 'Abdülkạdir b. Yūsuf Kạnī̄ } \\
\text { Efendi (A; KOHD) }\end{array}$ & Ms.or.quart. 1571 \\
\hline 382. & 05.06 .1926 & Behcetü'l-fetāvā, Yeñişehrli 'Abdullāh Efendi (T; 13/5, 112) & Ms.or.fol. 4077 \\
\hline 383. & 05.06.1926 & Bedāyi 'ü’ṣ-ṣukūk, Meḥmed Șādıḳ (T; 13/4, 72) & Ms.or.quart. 1525 \\
\hline 384. & 05.06.1926 & $\begin{array}{l}\text { Lemahāt-ı leme 'āt el-bahrü'l-ma 'nevī, Dervīş 'Alī 'İlmī Dede (T; } \\
\qquad 13 / 2,618)\end{array}$ & Ms.or.oct. 2343 \\
\hline 385. & 05.06.1926 & Fetāvā-yı Üskübì, Üskübī (T; 13/5, 109) & Ms.or.fol. 4081 \\
\hline 386. & 05.06.1926 & $\begin{array}{l}\text { 1. Fetāvā, Kemālpaşazāde (T; 13/4, 88) } \\
\text { 2. el-Vașiyetü Ebū Hanīfe (A; UC) } \\
\text { 3. Had̄īs }(\mathrm{A} ; \mathrm{UC}) \\
\text { 4. Dürr-i meknūn (T; 13/4, 126) }\end{array}$ & Ms.or.oct. 2391 \\
\hline 387. & 05.06 .1926 & el-Fetāve'l- 'adliye, Resūl b. Șāliḥ el-Aydınī (A; KOHD) & Ms.or.oct. 2293 \\
\hline 388. & 05.06.1926 & Cāmi '̈̈'l-icāreteyn, Şāṭrzāde Meḥmed 'Ārif (T; 13/5, 118) & Ms.or.fol. 4068 \\
\hline
\end{tabular}


The Manuscripts Rescher Sold to the Berlin State Library (Reşer'in Berlin Devlet Kütüphanesi'ne Sattığı Yazmalar)

\begin{tabular}{|c|c|c|c|}
\hline Nr. & $\begin{array}{l}\text { Date } \\
\text { Tarih }\end{array}$ & $\begin{array}{c}\text { Name of Work, Name of Author (Language; Catalogue } \\
\text { Information) } \\
\text { Eser adı, Müellif adı (Dil; Katalog Bilgisi) }\end{array}$ & $\begin{array}{l}\text { Shelf nr. } \\
\text { Raf nr. }\end{array}$ \\
\hline 389. & 05.06 .1926 & 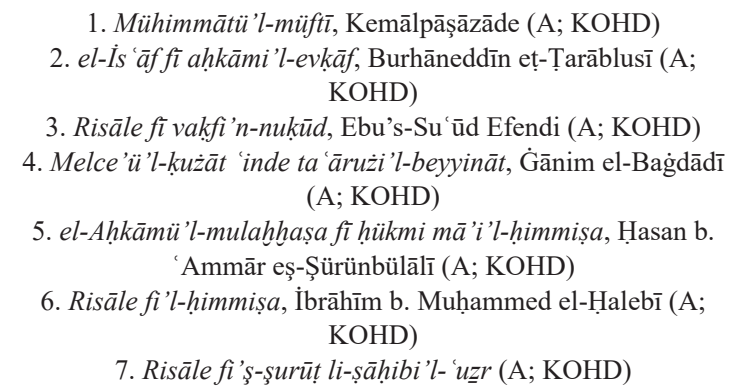 & Ms.or.oct. 2337 \\
\hline 390. & 05.06 .1926 & Netīcetü'l-fetāvā, Meḥmed b. Aḥmed Gedüsī (T; 13/4, 87) & Ms.or.quart. 1541 \\
\hline 391. & 05.06 .1926 & Nihāyetü'l-īcāz fì dirāyeti'l-i c'cāz, Fahreddīn er-Rāzī (A; KOHD) & Ms.or.oct. 2336 \\
\hline 392. & 05.06 .1926 & $\begin{array}{c}\text { el-Fevā'ihü̈l- 'irfāniye fi'l-medā'ihi'l- 'Üryāniye, Mahmmūd b. } \\
\text { 'Abdülmuhsin el-Muvaḳi (A; KOHD) }\end{array}$ & Ms.or.quart. 1539 \\
\hline 393. & 05.06 .1926 & $\begin{array}{l}\text { 1. Hakāâyı ve dakāàyı, Aḥmed-i Rūmī (F; KOHD) } \\
\text { 2. Ümmü'l-kitāb, Aḥmed-i Rūmī (F; KOHD) } \\
\text { 3. Mecālis-i 'aşere (F; KOHD) }\end{array}$ & Ms.or.quart. 1533 \\
\hline 394. & 05.06 .1926 & $\begin{array}{l}\text { 1. Dīvāan, Kāà'imī (T; 13/2, 419) } \\
\text { 2. el-Minhatü'r-rabbāniye, ed-Demenhūrī (A; KOHD) }\end{array}$ & Ms.or.oct. 2303 \\
\hline 395. & 05.06 .1926 & Hāşsiye 'alā Şerḥi Taṣrīfi'l- 'İzzì, Dede Cöngī (A; KOHD) & Ms.or.oct. 2321 \\
\hline 396. & 05.06 .1926 & Menḳabet-i Yahyyā-yı Beşikṭaşī, Dā'̄i (T; 13/4, 129) & Ms.or.oct. 2295 \\
\hline 397. & 05.06 .1926 & 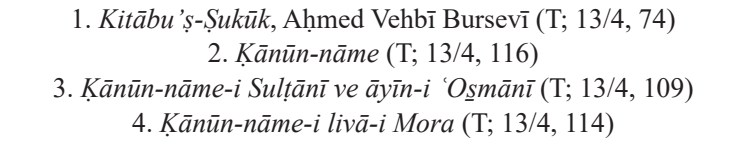 & Ms.or.oct. 2393 \\
\hline 398. & 05.06 .1926 & $\begin{array}{l}\text { Şeyh Mạ̣mūd b. Edhem: } \\
\text { 1. Gülş̧en-i inşā' (T; 13/4, 285) } \\
\text { 2. Münşe 'ât }(\mathrm{T} ; 13 / 4,286)\end{array}$ & Ms.or.oct. 2349 \\
\hline 399. & 05.06 .1926 & 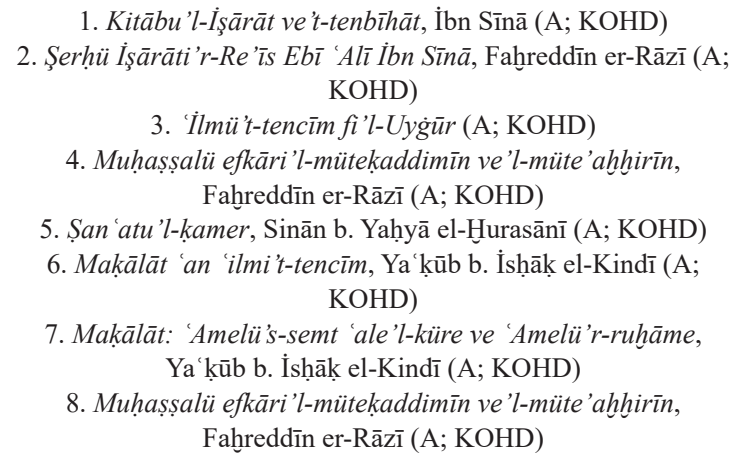 & Ms.or.oct. 2294 \\
\hline
\end{tabular}


The Manuscripts Rescher Sold to the Berlin State Library (Reşer'in Berlin Devlet Kütüphanesi'ne Sattığı Yazmalar)

\begin{tabular}{|c|c|c|c|}
\hline Nr. & $\begin{array}{l}\text { Date } \\
\text { Tarih }\end{array}$ & $\begin{array}{c}\text { Name of Work, Name of Author (Language; Catalogue } \\
\text { Information) } \\
\text { Eser adı, Müellif adı (Dil; Katalog Bilgisi) }\end{array}$ & $\begin{array}{l}\text { Shelf nr. } \\
\text { Raf nr. }\end{array}$ \\
\hline 400. & 05.06 .1926 & 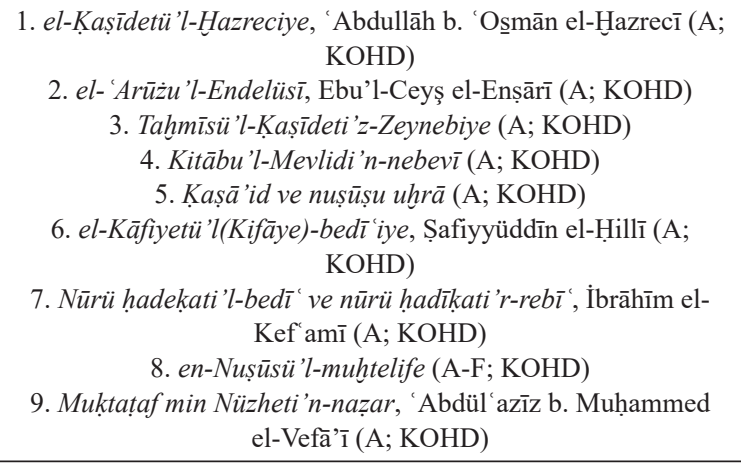 & Ms.or.quart. 1572 \\
\hline 401. & 05.06 .1926 & Müntehab-ı tevārīh-i vüzerā $(\mathrm{T} ; 13 / 4,272)$ & Ms.or.oct. 2296 \\
\hline 402. & 05.06 .1926 & Münşe'āt $(\mathrm{T} ; 13 / 4,299)$ & Ms.or.oct. 2396 \\
\hline 403. & 05.06 .1926 & $\begin{array}{l}\text { 1. Mu 'ammeyāt-ı Mevlānā Kāmī, Kāmī (F; KOHD) } \\
\text { 2. Hilyetü'l-ḥulel, 'Abdurraḥmān Cāmī (F; KOHD) }\end{array}$ & Ms.or.oct. 2305 \\
\hline 404. & 05.06 .1926 & $\begin{array}{l}\text { Karaçelebizāde 'Abdül'azīz Efendi: } \\
\text { 1. Ravżatü'l-ebrār }(\mathrm{T} ; 13 / 4,244) \\
\text { 2. Zeyl-i tārīh }(\mathrm{T} ; 13 / 4,245)\end{array}$ & Ms.or.oct. 2342 \\
\hline 405. & 08.06 .1926 & 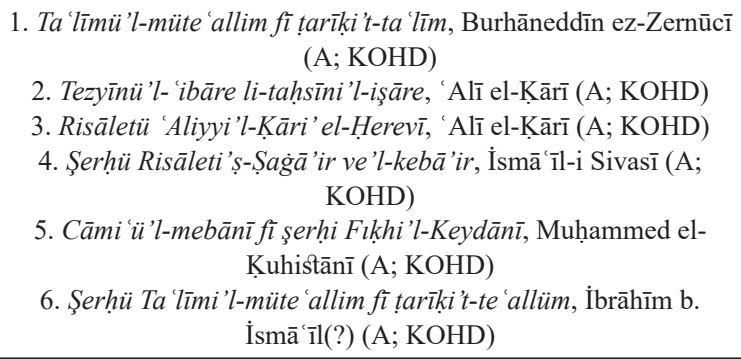 & Ms.or.quart. 1527 \\
\hline 406. & 08.06 .1926 & 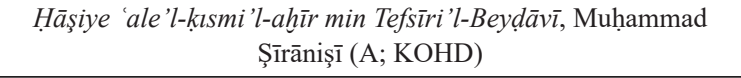 & Ms.or.oct. 2322 \\
\hline 407. & 08.06 .1926 & Terceme-i Muhtașar-ı Kudūrī, İsmā'îl Müfĩd Beg (T; 13/4, 68) & Ms.or.oct. 2401 \\
\hline 408. & 08.06 .1926 & $\begin{array}{c}\text { el-Erba 'ūn fi'l-erba 'ìn min ehāāissi Seyyidi'l-mürselīn, } \\
\text { 'Abdurraḥmān Nācim Efendi }(\mathrm{T} ; 13 / 4,30)\end{array}$ & Ms.or.oct. 2335 \\
\hline 409. & 08.06 .1926 & $\begin{array}{c}\text { Eşrefü'l-vesāàil ilā fehmi 'ş-Şemā'il, Ahmed b. Muhammed el- } \\
\text { Heyșemī (A; KOHD) }\end{array}$ & Ms.or.quart. 1553 \\
\hline
\end{tabular}


The Manuscripts Rescher Sold to the Berlin State Library (Reşer'in Berlin Devlet Kütüphanesi'ne Sattığı Yazmalar)

\begin{tabular}{|c|c|c|c|}
\hline Nr. & $\begin{array}{l}\text { Date } \\
\text { Tarih }\end{array}$ & $\begin{array}{c}\text { Name of Work, Name of Author (Language; Catalogue } \\
\text { Information) } \\
\text { Eser adı, Müellif adı (Dil; Katalog Bilgisi) }\end{array}$ & $\begin{array}{l}\text { Shelf nr. } \\
\text { Raf nr. }\end{array}$ \\
\hline 410. & 08.06 .1926 & 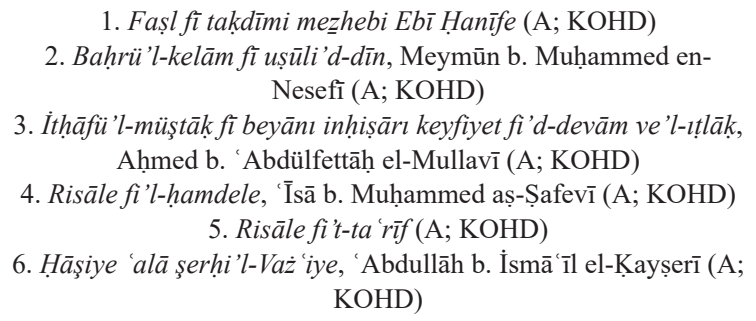 & Ms.or.quart. 1526 \\
\hline 411. & 08.06 .1926 & 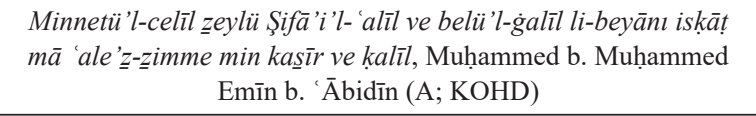 & Ms.or.fol. 4082 \\
\hline 412. & 08.06 .1926 & 'Umdetü'l- 'irfān fì vechi'l-Ḳur'ān, Mușțafà İzmirī (A; KOHD) & Ms.or.oct. 2400 \\
\hline 413. & 08.06 .1926 & $\begin{array}{c}\text { el-Fütūhātü'l-medeniye fi aḩbāri dāri hayre'l-beriye, Aḥmed b. } \\
\text { Manșūr er-Rifā' } \overline{1}(\mathrm{~A} ; 17 \mathrm{~B} / 2,196)\end{array}$ & Ms.or.oct. 2344 \\
\hline 414. & 08.06 .1926 & 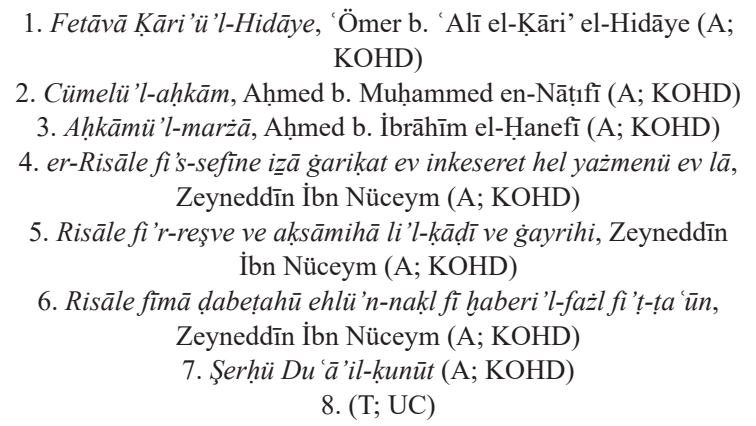 & Ms.or.oct. 2325 \\
\hline 415. & 08.06 .1926 & Nazmü'l-beyān, Mușțafā Remzī el-Anțākī (A; KOHD) & Ms.or.oct. 2307 \\
\hline 416. & 08.06 .1926 & 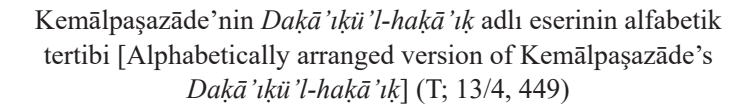 & Ms.or.oct. 2346 \\
\hline 417. & 08.06 .1926 & $\begin{array}{l}\text { 1. Şerhü'l-Ferā'iżi’s-Sirācīye, Kemālpaşazāde (A; KOHD) } \\
\text { 2. el-Ferā'iżü’ş-Şerīfiye, Seyyid Şerīf el-Cürcānī (A; KOHD) }\end{array}$ & Ms.or.oct. 2347 \\
\hline 418. & 08.06 .1926 & 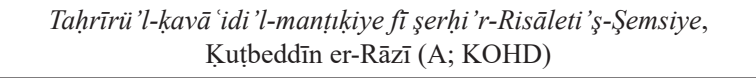 & Ms.or.oct. 2345 \\
\hline 419. & 08.06 .1926 & Hadīkatü'l-Ma 'ārif, Şücā eddīn-i Kurbālī (F-A; KOHD) & Ms.or.fol. 4083 \\
\hline 420. & 08.06 .1926 & 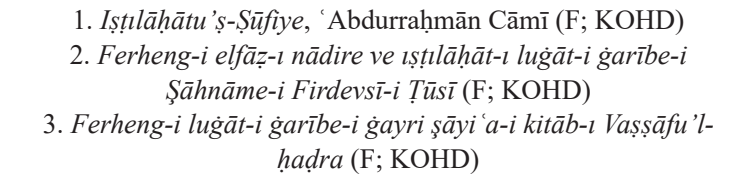 & Ms.or.quart. 1540 \\
\hline
\end{tabular}


The Manuscripts Rescher Sold to the Berlin State Library (Reşer'in Berlin Devlet Kütüphanesi'ne Sattığı Yazmalar)

\begin{tabular}{|c|c|c|c|}
\hline Nr. & $\begin{array}{l}\text { Date } \\
\text { Tarih }\end{array}$ & $\begin{array}{c}\text { Name of Work, Name of Author (Language; Catalogue } \\
\text { Information) } \\
\text { Eser adı, Müellif adı (Dil; Katalog Bilgisi) }\end{array}$ & $\begin{array}{l}\text { Shelf nr. } \\
\text { Raf nr. }\end{array}$ \\
\hline 421. & 08.06 .1926 & $\begin{array}{c}\text { Makāạsıldu'l- 'aliye fì şerhi 't-Tā'iye, İsmā '̄il Rüsūh̄ī Anḳaravī (T; } \\
13 / 5,260)\end{array}$ & Ms.or.quart. 1574 \\
\hline 422. & 08.06 .1926 & Luġat-i Ni 'metullāh, Ni 'metullāh b. Aḥmed (F-T; 13/4, 475) & Ms.or.oct. 2399 \\
\hline 423. & 08.06.1926 & Bahrü̉'l-ma 'ārif, Muṣliḥeddīn Mușțafā Surūrī (T; 13/2, 284) & Ms.or.oct. 2298 \\
\hline 424. & 08.06 .1926 & Mürşidü'l-muhāsibīn, Kātib 'Alā'eddīn (T; 13/4, 352) & Ms.or.oct. 2398 \\
\hline 425. & 08.06 .1926 & Menāzirïü'l-inşā', Maḥmūd Gāvān (F; KOHD) & Ms.or.oct. 2310 \\
\hline 426. & 08.06 .1926 & $\begin{array}{c}\text { Terceme-i Minhācü'l- 'äbidīn ilā cenneti rabbi'l- 'älemīn, İlyās } \\
\text { Nihānī }(\mathrm{T} ; 13 / 2,203)\end{array}$ & Ms.or.oct. 2309 \\
\hline 427. & 08.06 .1926 & $\begin{array}{l}\text { Zarīfì: } \\
\text { 1. Pend-nāme }(\mathrm{T} ; 13 / 2,213) \\
\text { 2. Tașavvuf-nāme }(\mathrm{T} ; 13 / 2,118)\end{array}$ & Ms.or.quart. 1567 \\
\hline 428. & 08.06 .1926 & '̇̀āāāt-ı Bedeniye $(\mathrm{T} ; 13 / 4,58)$ & Ms.or.oct. 2403 \\
\hline 429. & 08.06 .1926 & $\begin{array}{l}\text { 1. Dìvān, Nāșị 'Alī Sirhindī (F; KOHD) } \\
\text { 2. Dìvān, Şevket-i Buhāāì (F; KOHD) }\end{array}$ & Ms.or.oct. 2404 \\
\hline 430. & 08.06.1926 & $\begin{array}{l}\text { 1. el-Hedīyetü'r-reşīdiye fi'l-ictimā ' bi-seyyidi'l-beriye ve't- } \\
\text { teveccüh ile'n-nefsi'l-kudsiye 'alā șāhhibihi'ṣ-șalāt ve t-tahiye, } \\
\text { İsmā'îl b. Muhammed Nevvāb (A; KOHD) } \\
\text { 2. Risāletü'l-murākabe, İsmā'îl b. Muhammed Nevvāb (A; } \\
\text { KOHD) } \\
\text { 3. Risāle-i Nūrbahş, 'Abdurraḥmān Cāmī (F; KOHD) }\end{array}$ & Ms.or.oct. 2402 \\
\hline 431. & 08.06 .1926 & $\begin{array}{l}\text { Risāletü 't-tevhīdiye fì ma 'rifeti 't-taklīdiye, Nūr 'Alī Hemedānī (F; } \\
\qquad 14 / 1,282)\end{array}$ & Ms.or.oct. 2324 \\
\hline 432. & 08.06 .1926 & 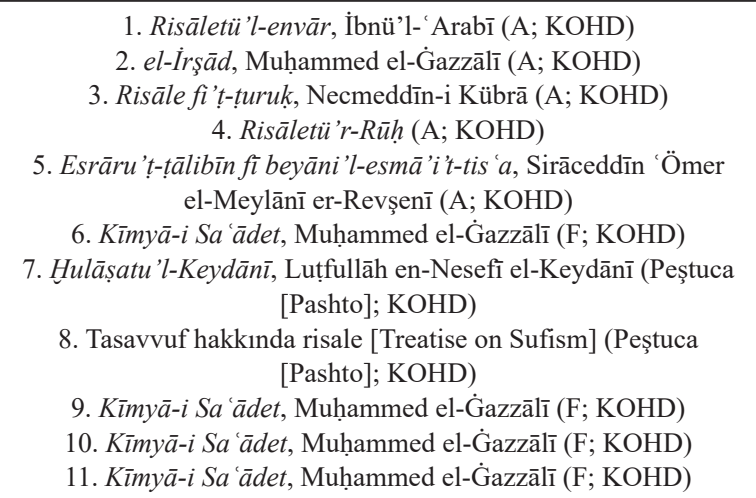 & Ms.or.fol. 4101 \\
\hline 433. & 08.06 .1926 & Mir'ātü'l-cemāl, İdrīs-i Bidlisī (F-A-T; KOHD) & Ms.or.oct. 2297 \\
\hline 434. & 08.06 .1926 & Zübdetü'n-neșā'ih mine 'ṣ-ṣahā'ih (F; 14/1, 190) & Ms.or.oct. 2288 \\
\hline 435. & 08.06 .1926 & $\begin{array}{l}\text { Hurufiye hakkında risale [Treatise on alphabetic prophecy], Mīr } \\
\text { 'Alī (F; UC) }\end{array}$ & Ms.or.oct. 2299 \\
\hline
\end{tabular}


The Manuscripts Rescher Sold to the Berlin State Library (Reşer'in Berlin Devlet Kütüphanesi'ne Sattığı Yazmalar)

\begin{tabular}{|c|c|c|c|}
\hline Nr. & $\begin{array}{l}\text { Date } \\
\text { Tarih }\end{array}$ & $\begin{array}{c}\text { Name of Work, Name of Author (Language; Catalogue } \\
\text { Information) } \\
\text { Eser adı, Müellif adı (Dil; Katalog Bilgisi) }\end{array}$ & $\begin{array}{l}\text { Shelf nr. } \\
\text { Raf nr. }\end{array}$ \\
\hline 436. & 08.06 .1926 & $\begin{array}{c}\text { Şerh-i Gülşen-i rāz, Ni met b. Maḥmūd en-Naḩcıvānī (F; 14/1, } \\
113)\end{array}$ & Ms.or.oct. 2308 \\
\hline 437. & 08.06 .1926 & Gülşen-i rāz, Şebüsterī (F; 14/1, 236) & Ms.or.oct. 2221 \\
\hline 438. & 08.06 .1926 & Dìvān, Muḥammad b. Yaḥyā Lāhīcī (F; 14/1, 116) & Ms.or.oct. 2323 \\
\hline 439. & 08.06 .1926 & $\begin{array}{l}\text { 1. Mir'ātü'l-muhakkikīn, Şebüsterī (F; KOHD) } \\
\text { 2. Mir'ātü'l-hakāà'ik, Muḥammed b. Maḥmūd Dihdār-1 Şīrāzī (F; } \\
\text { KOHD) }\end{array}$ & Ms.or.quart. 1528 \\
\hline 440. & 08.06 .1926 & $\begin{array}{l}\text { 1. Tasavvuf hakkında risale [Treatise on Sufism] (F; KOHD) } \\
\text { 2. Havrā ’iye, Kāāsım-1 Envār (F; KOHD) } \\
\text { 3. Risāle-i Te'vīlāt-ı Kāşānī, Ni metullāh el-Kirmānī (F; KOHD) }\end{array}$ & Ms.or.oct. 2290 \\
\hline 441. & 08.06 .1926 & Risāle-i Mebde've me 'ād (T-F-A; KOHD) & Ms.or.oct. 2300 \\
\hline 442. & 08.06 .1926 & İşādü'l-müslimīn, Burhān el-Miskīn (F; 14/1, 200) & Ms.or.oct. 2397 \\
\hline 443. & 08.06 .1926 & 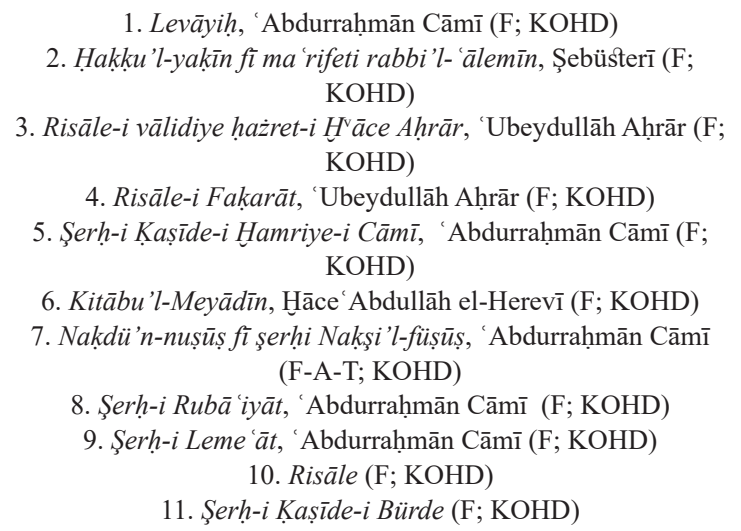 & Ms.or.fol. 4085 \\
\hline 444. & 08.06 .1926 & Dīvān, Mīrzā Sa deddīn Muḥammed (Rāḳım) (F; 14/1, 27) & Ms.or.oct. 2306 \\
\hline 445. & 08.06 .1926 & Şerhü̈l-Lübāb, el-Fālī (A; 17A/1, 75) & Ms.or.fol. 4086 \\
\hline 446. & 08.06 .1926 & Fetāvā $(\mathrm{T} ; 13 / 5,108)$ & Ms.or.quart. 1575 \\
\hline 447. & 08.06 .1926 & $\begin{array}{l}\text { 1. Tarīka-i Evrād ve evkāt, Emīr-i Kebīr-i Hemedānī (F; KOHD) } \\
\text { 2. Bāb der beyān-ı tāc-nāme (F; KOHD) } \\
\text { 3. Tasavvuf hakkında risale [Treatise on Sufism], 'Abdușșamed } \\
\text { b. Kul Muhammed (F; KOHD) } \\
\text { 4. Tasavvuf hakkında risale [Treatise on Sufism] (F; KOHD) } \\
\text { 5. Neşātü'l- 'sşk, 'Abdullāh b. Hüseyn el-Hüseynī (F; KOHD) } \\
\text { 6. Risāle (F; KOHD) }\end{array}$ & Ms.or.oct. 2289 \\
\hline 448. & 28.06 .1926 & 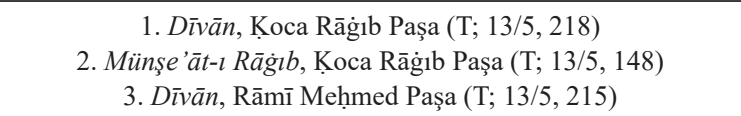 & Ms.or.fol. 4104 \\
\hline
\end{tabular}


The Manuscripts Rescher Sold to the Berlin State Library (Reşer'in Berlin Devlet Kütüphanesi'ne Sattığı Yazmalar)

\begin{tabular}{|c|c|c|c|}
\hline Nr. & $\begin{array}{l}\text { Date } \\
\text { Tarih }\end{array}$ & $\begin{array}{c}\text { Name of Work, Name of Author (Language; Catalogue } \\
\text { Information) } \\
\text { Eser adı, Müellif adı (Dil; Katalog Bilgisi) }\end{array}$ & $\begin{array}{l}\text { Shelf nr. } \\
\text { Raf nr. }\end{array}$ \\
\hline 449. & 28.06.1926 & 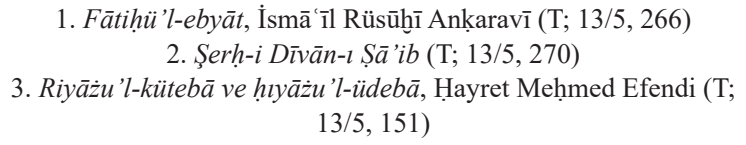 & Ms.or.fol. 4059 \\
\hline 450. & 28.06.1926 & Mecmū'a-i mekātīb (T; 13/5, 147) & Ms.or.quart. 1577 \\
\hline 451. & 28.06.1926 & $\begin{array}{l}\text { 1. İlm-i nücum hakkında risale [Treatise on astronomy], Mehmed } \\
\text { b. 'Alī (T; } 13 / 1,397) \\
\text { 2. İlm-i nücuma dair izahat [Instructions about astronomy] (T; } \\
13 / 1,413) \\
\text { 3. Gurrenāme }(\mathrm{T} ; 13 / 1,402)\end{array}$ & Ms.or.quart. 1504 \\
\hline 452. & 28.06 .1926 & Tuhfe-i 'Ațà'iye, İsmā' îl Hạḳ̄i Bursevī (T; 13/2, 49) & Ms.or.oct. 2406 \\
\hline 453. & 28.06.1926 & $D u$ 'ä-nāme, Ebu's-Su 'ūd Efendi (T; 13/4, 173) & Ms.or.oct. 2407 \\
\hline 454. & 28.06 .1926 & Mīzānü'l-ḥakk fì ihtiyāri'l-ehakk, Kātib Çelebi (T; 13/4, 137) & Ms.or.oct. 2217 \\
\hline 455. & 28.06.1926 & Minhācü'l-fukarā', İsmā '̄l Rüsūh̄ì Anḳaravī (T; 13/2, 88) & Ms.or.quart. 1505 \\
\hline 456. & 28.06 .1926 & Șukūk, Mūsāzāde Meḥmed 'Ubeydullāh (T; 13/5, 125) & Ms.or.fol. 4071 \\
\hline 457. & 28.06.1926 & Dìvān, Ca ferī $(\mathrm{T} ; 13 / 2,337)$ & Ms.or.oct. 2408 \\
\hline 458. & 28.06.1926 & Terceme-i Akrābāāin, 'Alī el-Bursevī (T; 13/4, 415) & Ms.or.oct. 2410 \\
\hline 459. & 28.06 .1926 & Kitāb-ı Mübekkiyāt, Ḥāfı̣ Aḥmed b. Ḥasan (T; 13/2, 177) & Ms.or.quart. 1506 \\
\hline 460. & 28.06 .1926 & 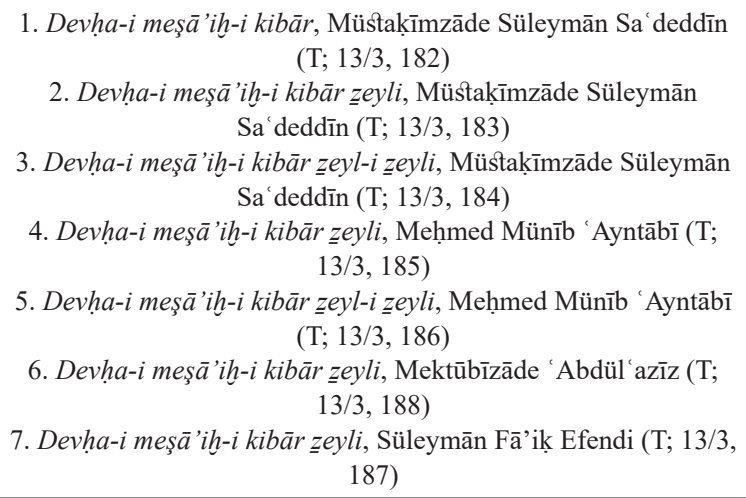 & Ms.or.oct. 2219 \\
\hline 461. & 28.06 .1926 & $\begin{array}{c}\text { Cāmi 'ü'l-envār fì menākıbı 'l-ebrār, Nazmīzāde Murtażā Efendi } \\
\text { (T; 13/1, 257) }\end{array}$ & Ms.or.fol. 4067 \\
\hline
\end{tabular}


The Manuscripts Rescher Sold to the Berlin State Library (Reşer'in Berlin Devlet Kütüphanesi'ne Sattığı Yazmalar)

\begin{tabular}{|c|c|c|c|}
\hline Nr. & $\begin{array}{l}\text { Date } \\
\text { Tarih }\end{array}$ & $\begin{array}{l}\text { Name of Work, Name of Author (Language; Catalogue } \\
\text { Information) } \\
\text { Eser adı, Müellif adı (Dil; Katalog Bilgisi) }\end{array}$ & $\begin{array}{c}\text { Shelf nr. } \\
\text { Raf nr. }\end{array}$ \\
\hline 462. & 19.09 .1926 & 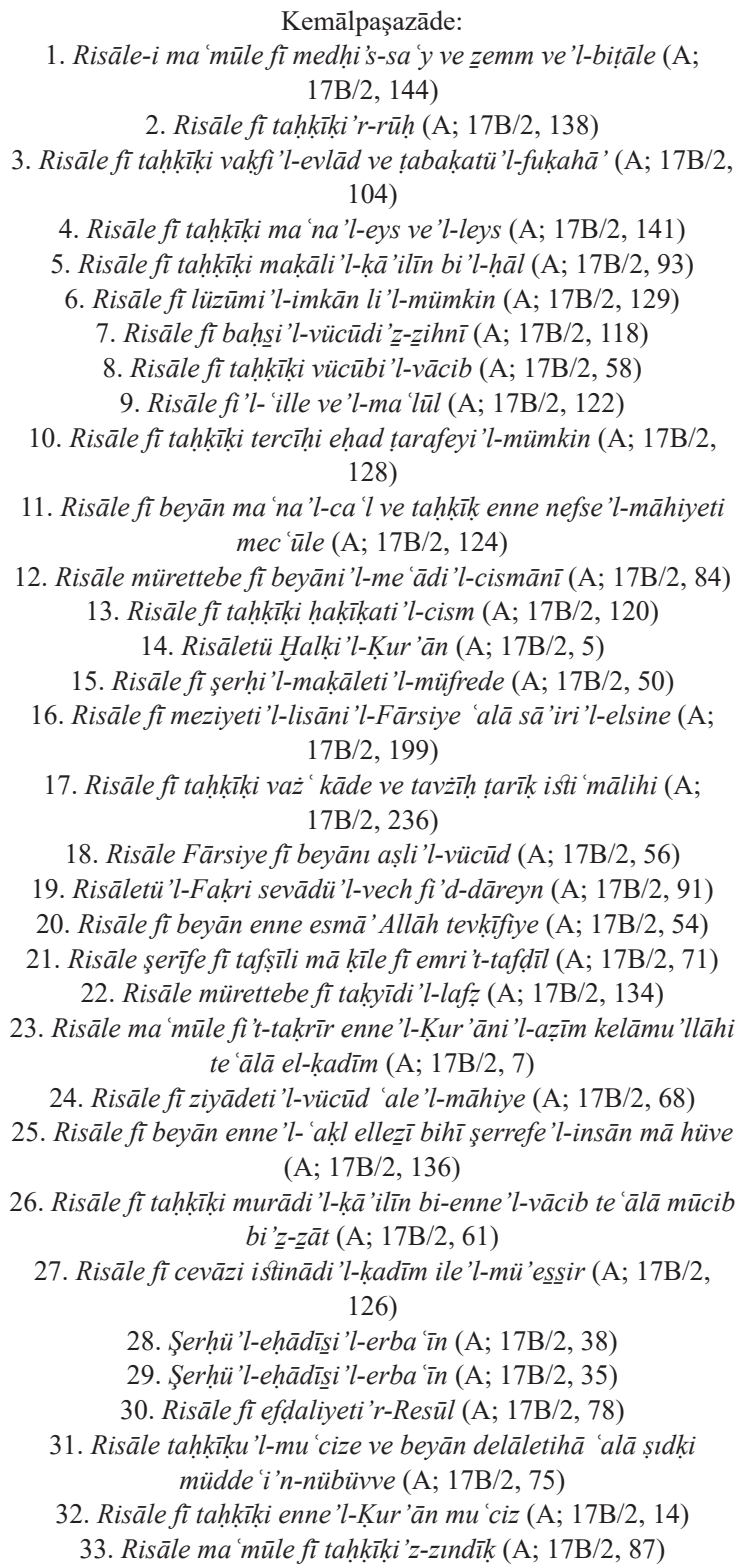 & Ms.or.fol. 4106 \\
\hline
\end{tabular}


The Manuscripts Rescher Sold to the Berlin State Library (Reşer'in Berlin Devlet Kütüphanesi'ne Sattığı Yazmalar)

\begin{tabular}{|c|c|c|c|}
\hline Nr. & $\begin{array}{l}\text { Date } \\
\text { Tarih }\end{array}$ & $\begin{array}{c}\text { Name of Work, Name of Author (Language; Catalogue } \\
\text { Information) } \\
\text { Eser adı, Müellif adı (Dil; Katalog Bilgisi) }\end{array}$ & $\begin{array}{l}\text { Shelf nr. } \\
\text { Raf nr. }\end{array}$ \\
\hline 462. & 19.09.1926 & 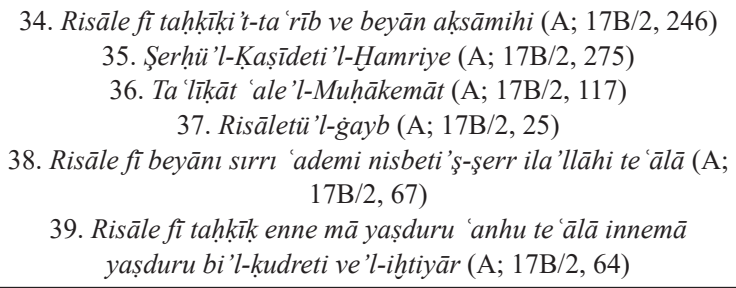 & Ms.or.fol. 4106 \\
\hline 463. & 19.09.1926 & Mecmū ${ }^{`} a-i$ fetāvā $(\mathrm{T} ; 13 / 4,97)$ & Ms.or.oct. 2416 \\
\hline 464. & 19.09.1926 & Kelīle ve Dimne, İbnü'l-Muḳaffa' (A; KOHD) & Ms.or.oct. 2411 \\
\hline 465. & 19.09.1926 & $\begin{array}{l}\text { 1. 'íbādāt-ı bedeniye }(\mathrm{T} ; 13 / 3,46) \\
\text { 2. Şurūṭ̂'ṣ-șalāt }(\mathrm{T} ; 13 / 3,47)\end{array}$ & Ms.or.oct. 2211 \\
\hline 466. & 19.09.1926 & Vak' a-i Selīmiye, Mușțafā Necīb (T; 13/4, 242) & Ms.or.oct. 2210 \\
\hline 467. & 19.09.1926 & 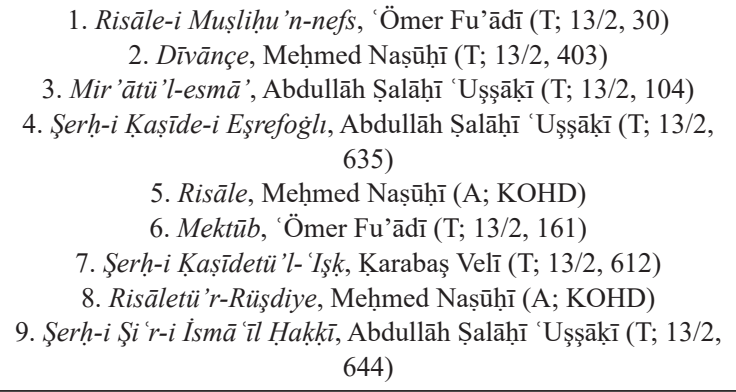 & Ms.or.quart. 1520 \\
\hline 468. & 19.09.1926 & Risāle, Meḥmed Șāliḥ (T; 13/5, 129) & Ms.or.fol. 4064 \\
\hline 469. & 19.09.1926 & Cevāhirü'ž-z̄āt, Ferīdeddīn-i 'Atțāâ (F; 14/1, 203) & Ms.or.oct. 2415 \\
\hline 470. & 19.09.1926 & Mevlid, Bihişt̄̄ Aḥmed Sinān Efendi (T; 13/4, 487) & Ms.or.oct. 2413 \\
\hline 471. & 19.09.1926 & Șahā'iffi'l-lugati'l-Fārsiye (A-F; KOHD) & Ms.or.oct. 2312 \\
\hline 472. & 19.09.1926 & $\begin{array}{l}\text { 1. Şerhü̈r-Risāleti'l-kadīme fì is bāti'l-vācib li'd-Devvānī (A; } \\
\text { KOHD) } \\
\text { 2. Hāşiye 'alā Şerhi'r-Risāleti'l-kadīme fì is bāti'l-vācib li'd- } \\
\text { Devvānì (A; KOHD) }\end{array}$ & Ms.or.oct. 2334 \\
\hline 473. & 19.09.1926 & $\begin{array}{l}\text { 1. Tuhfetü'l-ihvvān fì ādābi'ț-țarīk, Aḥmed ed-Derdīr (A; KOHD) } \\
\text { 2. Medāricü's-sālikīn ilāa rüsūmi țarīki'l- 'ārifìn, Ebu'l-Mevāhib } \\
\text { 'Abdülvehhāb eş-Şa rānī (A; KOHD) }\end{array}$ & Ms.or.quart. 1579 \\
\hline 474. & 19.09.1926 & Mecmū 'a-i mūsik̄i (T; 13/5, 290) & Ms.or.quart. 1578 \\
\hline 475. & 19.09.1926 & Mecmū 'atü'r-Resā'il li'r-reml (T-A; UC-GDA) & Ms.or.quart. 1580 \\
\hline 476. & 19.09.1926 & Kitābu'l-Maḥbūb, Sa'deddīn-i Ḥammūye (A; KOHD) & Ms.or.fol. 4084 \\
\hline 477. & 19.09.1926 & Ebyāt-ı Vașșāf, 'Abdullāh b. Fażlullāh Vașșāf (A; 17B/1, 402) & Ms.or.oct. 2326 \\
\hline
\end{tabular}


The Manuscripts Rescher Sold to the Berlin State Library (Reşer'in Berlin Devlet Kütüphanesi'ne Sattığı Yazmalar)

\begin{tabular}{|c|c|c|c|}
\hline Nr. & $\begin{array}{l}\text { Date } \\
\text { Tarih }\end{array}$ & $\begin{array}{c}\text { Name of Work, Name of Author (Language; Catalogue } \\
\text { Information) } \\
\text { Eser adı, Müellif adı (Dil; Katalog Bilgisi) }\end{array}$ & $\begin{array}{l}\text { Shelf nr. } \\
\text { Raf nr. }\end{array}$ \\
\hline 478. & 19.09.1926 & $\begin{array}{l}\text { Selāsilü'l-cevāhir ve'l- 'ukūd ve buhūr zebed 'arā'isü'l-vücūd, } \\
\text { Şemseddīn Muhammed el-'Ömerī }(\mathrm{A} ; 17 \mathrm{~B} / 1,395)\end{array}$ & Ms.or.oct. 2327 \\
\hline 479. & 19.09.1926 & $\begin{array}{c}\text { 'Ikdü'l-ecyād fi'ș-șāfināti'l-ciyād, Muhammed Paşa el-Cezā'irī } \\
\text { (A; KOHD) }\end{array}$ & Ms.or.fol. 4087 \\
\hline 480 . & 19.09.1926 & 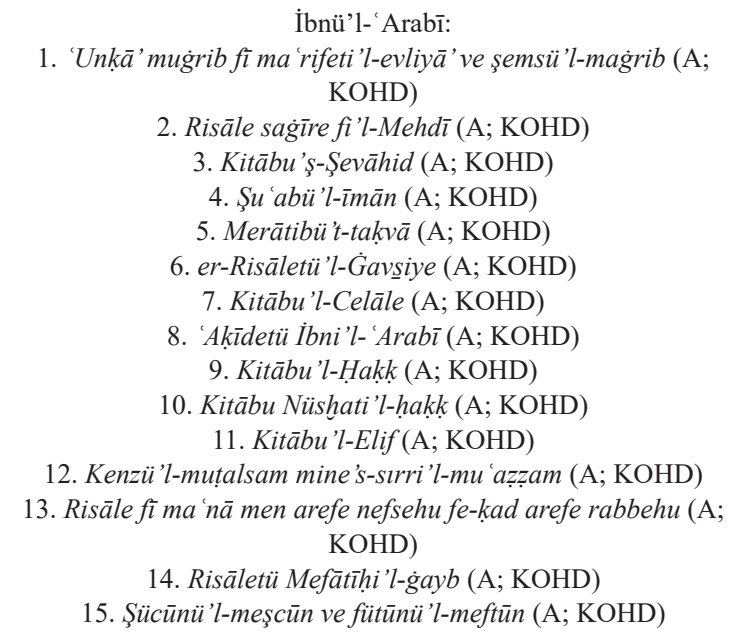 & Ms.or.quart. 1508 \\
\hline 481. & 19.09.1926 & $\begin{array}{l}\text { el- 'Urve li-ehli'l-halve ve'l-celve, 'Alā'üddevle-i Simnānī (A; } \\
17 \mathrm{~B} / 2,89)\end{array}$ & Ms.or.oct. 2313 \\
\hline 482. & 19.09.1926 & $\begin{array}{l}\text { 1. Kitābu Tarā 'ifi'ț-țraf, Maḥmūd b. Muhammed el-Bāri' el- } \\
\text { Herevī (A; 17B/2, 281) } \\
\text { 2. en-Necdiyāt, Ebu'l-Muzaffer el-Ebīverdī (A; 17B/2, 273) } \\
\text { 3. el-Mażnūn bihi 'alà ġayr ehlihi, 'İzzelmilleveddīn Ebu'l- } \\
\text { Feżā'il ez-Zencānī (A; 17B/2, 282) }\end{array}$ & Ms.or.oct. 2291 \\
\hline 483. & 19.09.1926 & Menhecü t-teysīr ilā 'ilmi 't-tefsīr, Manșūr eț-Ṭablāvī (A; KOHD) & Ms.or.oct. 2220 \\
\hline 484. & 19.09.1926 & Mekārimü’l-ahlāạ, el-Fażl b. el-Ḥasan eț-Ṭabersī (A; KOHD) & Ms.or.quart. 1536 \\
\hline 485. & 19.09.1926 & 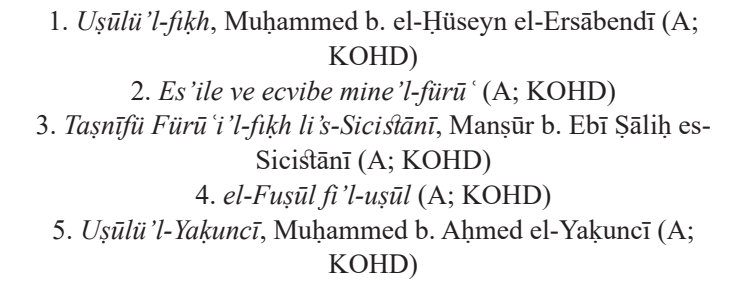 & Ms.or.quart. 1516 \\
\hline
\end{tabular}


The Manuscripts Rescher Sold to the Berlin State Library (Reşer'in Berlin Devlet Kütüphanesi'ne Sattığı Yazmalar)

\begin{tabular}{|c|c|c|c|}
\hline Nr. & $\begin{array}{l}\text { Date } \\
\text { Tarih }\end{array}$ & $\begin{array}{c}\text { Name of Work, Name of Author (Language; Catalogue } \\
\text { Information) } \\
\text { Eser adı, Müellif adı (Dil; Katalog Bilgisi) }\end{array}$ & $\begin{array}{l}\text { Shelf nr. } \\
\text { Raf nr. }\end{array}$ \\
\hline 486. & 19.09.1926 & 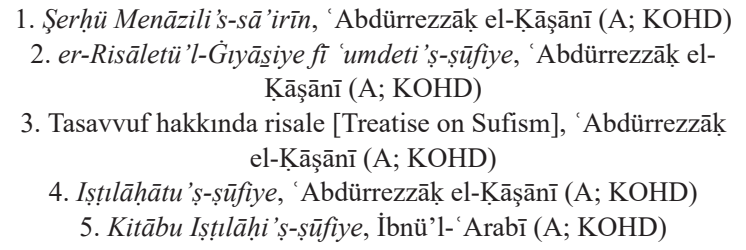 & Ms.or.fol. 4063 \\
\hline 487. & 19.09.1926 & el-Mesā'il li-ìżāhi'l-mesā'il, İbnü’l-'Arabī (A; KOHD) & Ms.or.oct. 2208 \\
\hline 488. & 19.09.1926 & $\begin{array}{l}\text { 1. Risāle fi'l-cefr (A; KOHD) } \\
\text { 2. Dā'iretü āyāti'llāhi te 'āla ve esmā'ihi'l-hüusnā (A; KOHD) }\end{array}$ & Ms.or.oct. 2209 \\
\hline 489. & 19.09.1926 & 'Uyūnü't-tevārīh, Ebū 'Abdillāh el-Kütübī (A; 17B/1, 469) & Ms.or.oct. 2301 \\
\hline 490. & 12.10.1926 & Kitābu'ț-Ṭıbbi'l-manżūm, Nidā'ī (T; 13/4, 400) & Ms.or.oct. 2314 \\
\hline 491. & 12.10.1926 & 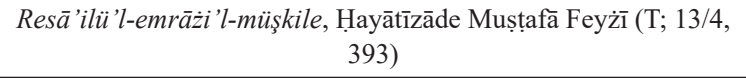 & Ms.or.oct. 2340 \\
\hline 492. & 12.10 .1926 & $\begin{array}{c}\text { Luğat-i Şāh-nāme, 'Abdülḳādir b. 'Ömer el-Baġdādī (F-T; 13/4, } \\
470)\end{array}$ & Ms.or.oct. 2315 \\
\hline 493. & 12.10.1926 & 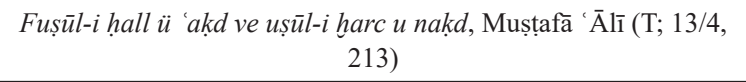 & Ms.or.oct. 2341 \\
\hline 494. & 12.10 .1926 & $\begin{array}{c}\text { el-Fülkü'l-meşhūn bi'l-lü'lü'i'l-meknūn, 'Abdüllațīf Rāzì (T; } \\
\text { 13/5, 286) }\end{array}$ & Ms.or.fol. 4107 \\
\hline 495. & 12.10 .1926 & $\begin{array}{c}\text { Mīzānü'l- 'ilel bi'l-kīrāt terceme-i Fușūl-i İbukrāt, } \\
\text { Fenārīdedezāde İbrāhīm (T; 13/4, 395) }\end{array}$ & Ms.or.oct. 2333 \\
\hline 496. & 12.10.1926 & $\begin{array}{l}\text { 1. Risāle-i Feyżiye fì luġāti'l-müfredāti’ț-țbbiye, Mușțafā Efendi } \\
\text { b. Meḥmed (T; 13/4, 398) } \\
\text { 2. Hāżihi Üslūb-l nārencāt, Mușțaā S- Sābit (T; 13/4, 373) }\end{array}$ & Ms.or.oct. 2316 \\
\hline 497. & 12.10.1926 & 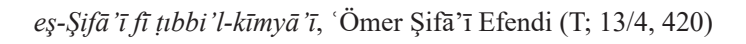 & Ms.or.oct. 2350 \\
\hline 498. & 12.10.1926 & Yādigār-ı İbn Şerīf, İbn Şerīf (T; 13/4, 394) & Ms.or.oct. 2351 \\
\hline 499. & 12.10 .1926 & İ lān-peżìr, Hạdī (T; 13/4, 232) & Ms.or.oct. 2353 \\
\hline 500. & 12.10 .1926 & Tebyīnü'l-merām, Țarīkatçi Emīr Şeyh Mușțafā (T; 13/5, 100) & Ms.or.quart. 1521 \\
\hline 501. & 12.10.1926 & $\begin{array}{l}\text { Kifäyetü'l-vaḳt li-ma 'rifeti'd-dā'ir ve fażluh ve 's-semt, Mușțafā b. } \\
\text { 'Alī el-Muvaḳkit (T; 13/4, 359) }\end{array}$ & Ms.or.oct. 2352 \\
\hline 502. & 12.10 .1926 & Münteḩab-ı Şifā, Ḥācı Paşa (Celāleddīn Hูıżr) (T; 13/5, 183) & Ms.or.quart. 1535 \\
\hline 503. & 12.10 .1926 & Risāle-i Hicāmet, 'Oșmān b. Mūsā Eskişehrī (T; 13/4, 402) & Ms.or.oct. 2419 \\
\hline 504. & 12.10 .1926 & 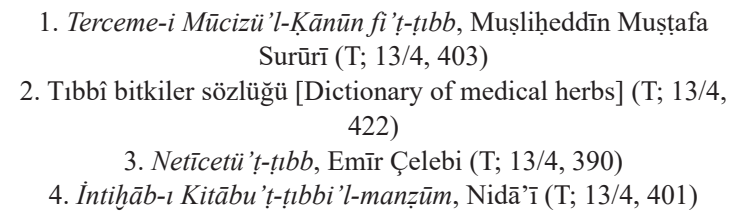 & Ms.or.oct. 2276 \\
\hline
\end{tabular}


The Manuscripts Rescher Sold to the Berlin State Library (Reşer'in Berlin Devlet Kütüphanesi'ne Sattığı Yazmalar)

\begin{tabular}{|c|c|c|c|}
\hline Nr. & $\begin{array}{l}\text { Date } \\
\text { Tarih }\end{array}$ & $\begin{array}{c}\text { Name of Work, Name of Author (Language; Catalogue } \\
\text { Information) } \\
\text { Eser adı, Müellif adı (Dil; Katalog Bilgisi) }\end{array}$ & $\begin{array}{l}\text { Shelf nr. } \\
\text { Raf nr. }\end{array}$ \\
\hline 505. & 12.10 .1926 & $\begin{array}{c}\text { Risāle-i Ta'dīl-i emzice fì h̆fẓi șiḥhati'l-beden, Şu 'ūrī Hạan } \\
\text { Efendi (T; 13/4, 407) }\end{array}$ & Ms.or.oct. 2280 \\
\hline 506. & 12.10 .1926 & Mecmū 'a-i eş 'ār (T; 13/2, 294) & Ms.or.oct. 2428 \\
\hline 507. & 12.10 .1926 & Teshīlü'l-mübtedī, Șalāḥ̄̄ b. Meḥmed (T; 13/4, 448) & Ms.or.oct. 2282 \\
\hline 508. & 12.10.1926 & 'Ukūdü'l-le'āl fì tercemeti'l-emșāl, Aḥmed Naẓif (T; 13/5, 206) & Ms.or.quart. 1512 \\
\hline 509. & 12.10 .1926 & 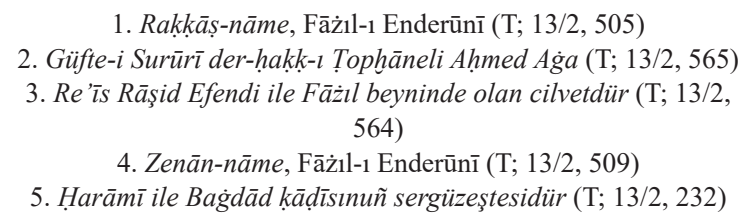 & Ms.or.oct. 2424 \\
\hline 510. & 12.10 .1926 & 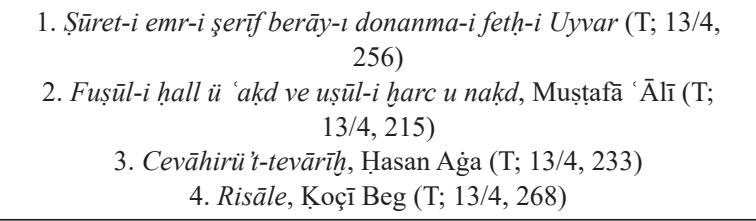 & Ms.or.oct. 2329 \\
\hline 511. & 12.10 .1926 & Meсmū'a (T; UC-GDA) & Ms.or.fol. 4108 \\
\hline 512. & 12.10.1926 & Münşe'āt-ı Kānī, Kānī (T; GDA) & Ms.or.oct. 2426 \\
\hline 513. & 12.10 .1926 & Müfredāt, Riyāżīzāde (T; 13/4, 418) & Ms.or.quart. 1530 \\
\hline 514. & 12.10 .1926 & $\begin{array}{l}\text { Kemālpaşazāde: } \\
\text { 1. Risāle-i Yā'iye }(\mathrm{T} ; 13 / 4,439) \\
\text { 2. Dekā'ıku'l-hakā'ık }(\mathrm{T} ; 13 / 4,437)\end{array}$ & Ms.or.oct. 2423 \\
\hline 515. & 12.10 .1926 & 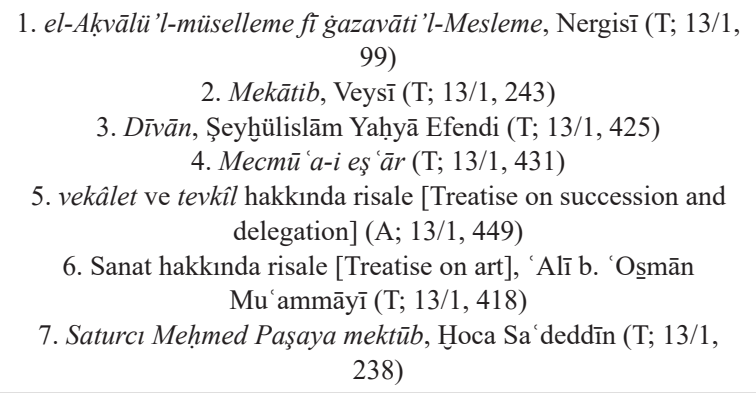 & Ms.or.fol. 4088 \\
\hline 516. & 12.10 .1926 & Rāhatü'l-ervāḥ, 'Abdurraḥmān Hātifī (T; 13/2, 575) & Ms.or.quart. 1522 \\
\hline 517. & 12.10 .1926 & 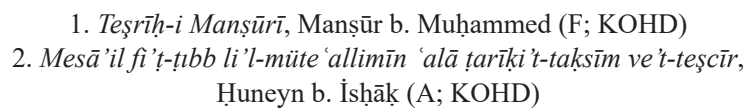 & Ms.or.quart. 1546 \\
\hline 518. & 12.10 .1926 & Terceme-i Mūciz, Aḥmed b. Kemāl (T; 13/5, 185) & Ms.or.fol. 4089 \\
\hline 519. & 12.10 .1926 & $\begin{array}{l}\text { Cerīdetü'r-rukūmi'l-felekiye fì ḥisābi'r-rüsūmi'l-belediye (A; } \\
\text { KOHD) }\end{array}$ & Ms.or.oct. 2317 \\
\hline
\end{tabular}


The Manuscripts Rescher Sold to the Berlin State Library (Reşer'in Berlin Devlet Kütüphanesi'ne Sattığı Yazmalar)

\begin{tabular}{|c|c|c|c|}
\hline Nr. & $\begin{array}{l}\text { Date } \\
\text { Tarih }\end{array}$ & $\begin{array}{c}\text { Name of Work, Name of Author (Language; Catalogue } \\
\text { Information) } \\
\text { Eser adı, Müellif adı (Dil; Katalog Bilgisi) }\end{array}$ & $\begin{array}{l}\text { Shelf nr. } \\
\text { Raf nr. }\end{array}$ \\
\hline 520. & 12.10.1926 & $\begin{array}{c}\text { Şerhü Kașīdeti'l-Bürde, Ḥamza b. 'Abdullāh-1 Karahịșārī (A; } \\
\text { KOHD) }\end{array}$ & Ms.or.quart. 1518 \\
\hline 521. & 12.10 .1926 & 'Ukletü'l-müstevfiz, İbnü'l-'Arabī (A; KOHD) & Ms.or.oct. 2418 \\
\hline 522. & 12.10.1926 & Melhametü'n-nebī Dānyāl (A; KOHD) & Ms.or.oct. 2279 \\
\hline 523. & 12.10.1926 & 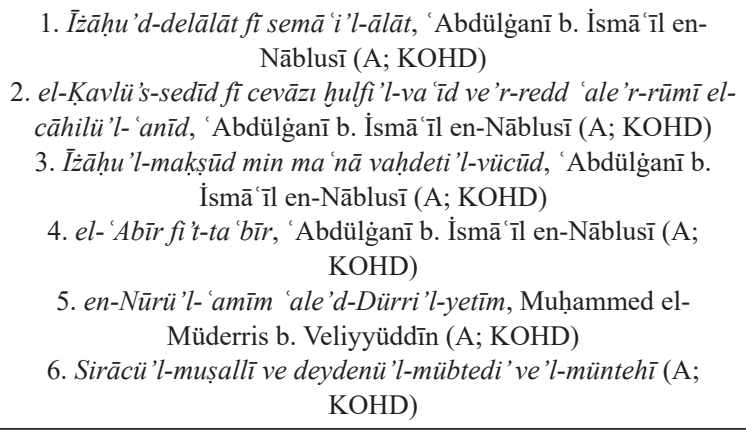 & Ms.or.quart. 1581 \\
\hline 524. & 12.10.1926 & $\begin{array}{c}\text { Cāmi 'ü'l-künūz ve nefā'isü̉'t-takrīrr, Hüuseyn b. Haydar et-Tebrīzī } \\
\text { (A; KOHD) }\end{array}$ & Ms.or.oct. 2286 \\
\hline 525. & 12.10.1926 & Tefsìr-i Yā-sin $(\mathrm{T} ; 13 / 4,14)$ & Ms.or.oct. 2278 \\
\hline 526. & 12.10.1926 & 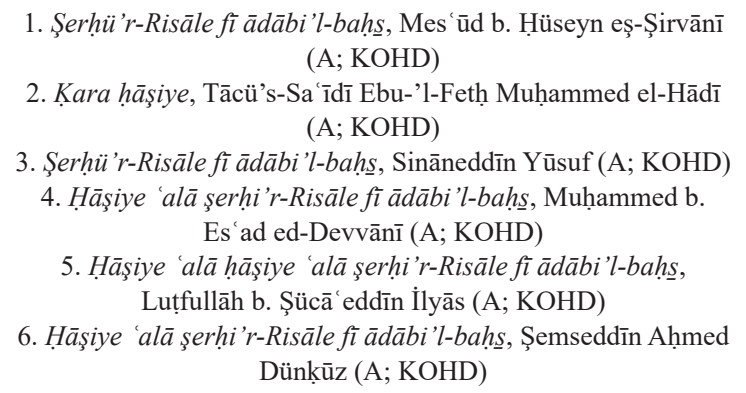 & Ms.or.oct. 2417 \\
\hline 527. & 12.10 .1926 & Kitābu İkāại’l-vesnān, Ebu'l-Ferec İbnü'l-Cevz̄i (A; KOHD) & Ms.or.quart. 1582 \\
\hline 528. & 12.10 .1926 & Mücerrebāt, Zekī Mușțafā Efendi (T; 13/4, 375) & Ms.or.oct. 2277 \\
\hline 529. & 12.10 .1926 & İșārātü'l-Kur 'ān fì 'ālemi'l-insān, İbnü'l- 'Arabī (A; KOHD) & Ms.or.oct. 2283 \\
\hline
\end{tabular}


The Manuscripts Rescher Sold to the Berlin State Library (Reşer'in Berlin Devlet Kütüphanesi'ne Sattığı Yazmalar)

\begin{tabular}{|c|c|c|c|}
\hline Nr. & $\begin{array}{l}\text { Date } \\
\text { Tarih }\end{array}$ & $\begin{array}{c}\text { Name of Work, Name of Author (Language; Catalogue } \\
\text { Information) } \\
\text { Eser adı, Müellif adı (Dil; Katalog Bilgisi) }\end{array}$ & $\begin{array}{l}\text { Shelf nr. } \\
\text { Raf nr. }\end{array}$ \\
\hline 530. & 12.10 .1926 & 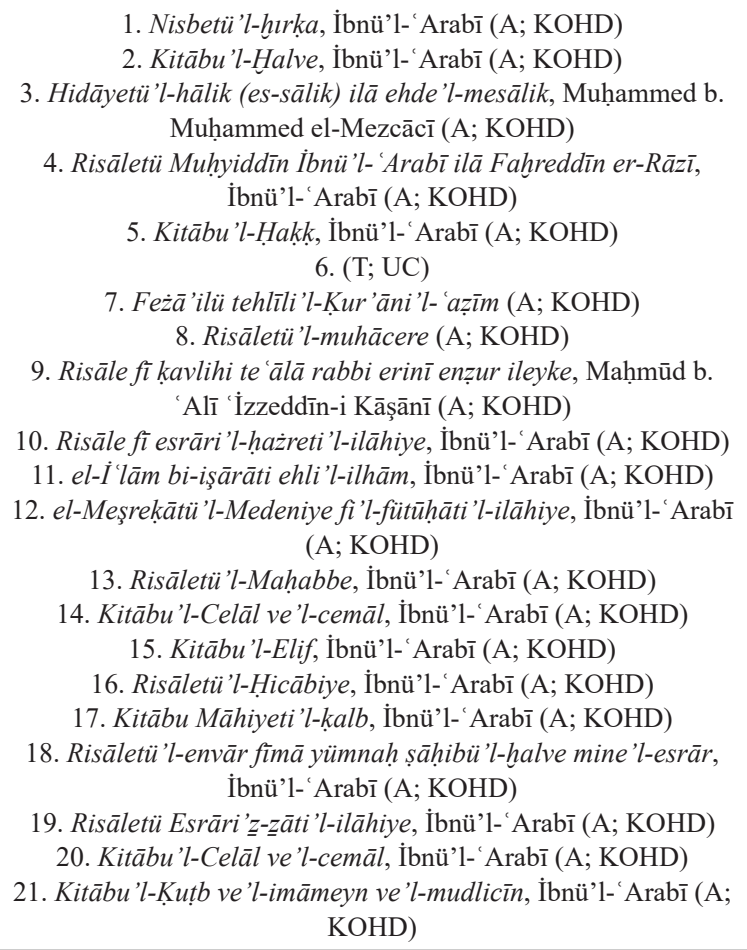 & Ms.or.quart. 1543 \\
\hline 531. & 12.10 .1926 & Hayr-ābād, Nābī (T; 13/2, 522) & Ms.or.oct. 2281 \\
\hline 532. & 12.10 .1926 & $\begin{array}{l}\text { Müsned Ebī Hanīfe min rivāyeti’l-Hașkefí, Nu 'mān b. Sāāit (A; } \\
\text { KOHD) }\end{array}$ & Ms.or.oct. 2421 \\
\hline 533. & 12.10 .1926 & 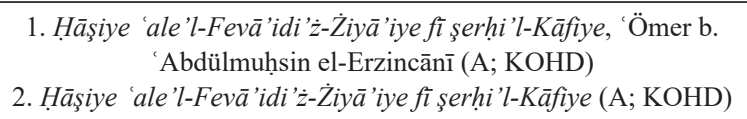 & Ms.or.oct. 2420 \\
\hline 534. & 12.10 .1926 & $\begin{array}{c}\text { Şerhü Erba 'ìn hadīsen fì țtbbi’n-Nebī, Şerīf b. Nāṣır el-Ḥasanī } \\
\text { (A; KOHD) }\end{array}$ & Ms.or.oct. 2425 \\
\hline 535. & 12.10 .1926 & 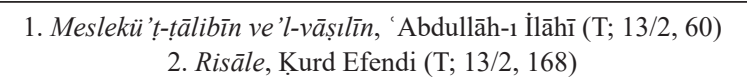 & Ms.or.oct. 2284 \\
\hline 536. & 12.10 .1926 & $\begin{array}{l}\text { 1. Şerh-i ebyāt-ı Mevlānā Celāleddīn kaddese sirruhu (F; } \\
\text { KOHD) } \\
\text { 2. Risāle-i Şerh-i Ma 'ñ̄-i ney, 'Abdurraḥmān Cāmī (F; KOHD) }\end{array}$ & Ms.or.oct. 2429 \\
\hline 537. & 12.10 .1926 & $\begin{array}{c}\text { Mețāli 'ü'l-meserrāt bi-celā'i Delā'ili'l-hayrāt, Muhammed el- } \\
\text { Mehdī b. Ahmed el-Fāsī (A; KOHD) }\end{array}$ & Ms.or.oct. 2427 \\
\hline
\end{tabular}


The Manuscripts Rescher Sold to the Berlin State Library (Reşer'in Berlin Devlet Kütüphanesi'ne Sattığı Yazmalar)

\begin{tabular}{|c|c|c|c|}
\hline Nr. & $\begin{array}{l}\text { Date } \\
\text { Tarih }\end{array}$ & $\begin{array}{c}\text { Name of Work, Name of Author (Language; Catalogue } \\
\text { Information) } \\
\text { Eser adı, Müellif adı (Dil; Katalog Bilgisi) }\end{array}$ & $\begin{array}{l}\text { Shelf nr. } \\
\text { Raf nr. }\end{array}$ \\
\hline 538. & 12.10 .1926 & 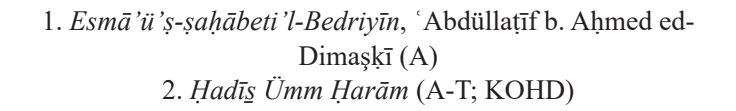 & Ms.or.oct. 2422 \\
\hline 539. & 12.10 .1926 & Feżā'il-i Mekke, Meḥmed Ebu'l-Fażl Sencārī (T; 13/1, 309) & Ms.or.fol. 4072 \\
\hline 540. & 04.11 .1926 & $\begin{array}{c}\text { Mir'ātü'l-kevneyn ve mübeyyin-i esrārü'l-hāafikayn, Ġulām Nebī } \\
\text { Firdevsī (F-A; KOHD) }\end{array}$ & Ms.or.fol. 4070 \\
\hline 541. & 04.11 .1926 & 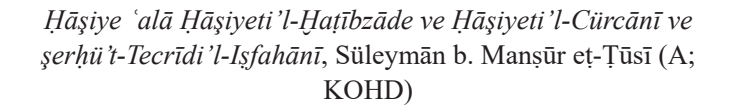 & Ms.or.quart. 1507 \\
\hline 542. & 04.11 .1926 & 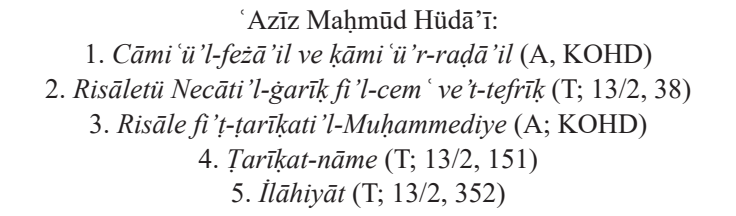 & Ms.or.oct. 2214 \\
\hline 543. & 04.11 .1926 & $\begin{array}{l}\text { İbrāhīm Çavuş (Sülūkī): } \\
\text { 1. Hāsş̧ye-i Levāzımu'l-hikmeti fi 'ț-țbb }(\mathrm{T} ; 13 / 4,396) \\
\text { 2. Muhtașar }(\mathrm{T} ; 13 / 4,397)\end{array}$ & Ms.or.fol. 4058 \\
\hline 544. & 04.11 .1926 & Dìvān, Şeyh 'Ubeydullāh (T; 13/2, 466) & Ms.or.oct. 2215 \\
\hline 545. & 04.11 .1926 & Dīvān, Ercesb b. Ḩvācegī Şāpūr-1 Tihrānī (F; KOHD) & Ms.or.fol. 4069 \\
\hline 546. & 04.11 .1926 & Dìvān, Meḥmed Şühūdī (T; 13/2, 454) & Ms.or.quart. 1509 \\
\hline 547. & 04.11 .1926 & $\begin{array}{c}\text { Terceme-i Cevāmi 'u'l-hikāyāt ve levāmi 'u'r-rivāyāt, Șāliḥ b. } \\
\text { Celāl }(\mathrm{T} ; 13 / 3,319)\end{array}$ & Ms.or.fol. 4109 \\
\hline 548. & 04.11 .1926 & $\begin{array}{c}\text { Nüzhetü'l-ebșār fi raḳā'iki l'l-eş 'ār, 'Abdullāh b. Muhammed eş- } \\
\text { Şebrāvī (A; KOHD) }\end{array}$ & Ms.or.quart. 1584 \\
\hline 549. & 04.11 .1926 & $\begin{array}{c}\text { Mir'ātü'l- 'uşşāk ve nūrü'l-aḥdāk, Karaḳaşzāde 'Ömer b. } \\
\text { Meḥmed (T; 13/2, 82) }\end{array}$ & Ms.or.quart. 1523 \\
\hline 550. & 04.11 .1926 & 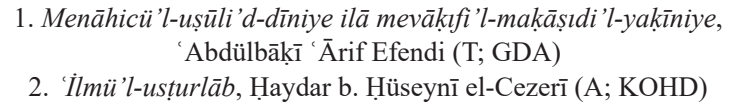 & Ms.or.oct. 2432 \\
\hline 551. & 04.11 .1926 & Tārīhn, Şeyhzāde Süleymān Efendi (T; 13/4, 257) & Ms.or.oct. 2433 \\
\hline 552. & 04.11 .1926 & 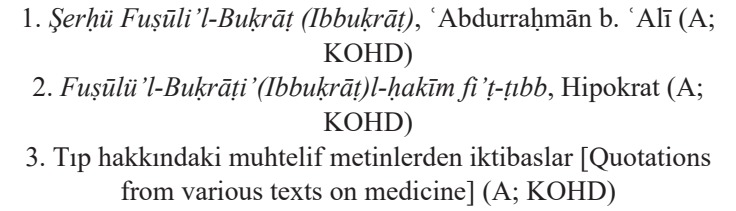 & Ms.or.oct. 2318 \\
\hline 553. & 04.11 .1926 & Nūrü’l-hüdā, Mușțafā Yūsuf (T; 13/4, 2) & Ms.or.oct. 2434 \\
\hline 554. & 04.11 .1926 & Fetāvā $(\mathrm{T} ; 13 / 5,107)$ & Ms.or.quart. 1547 \\
\hline 555. & 04.11 .1926 & Şecere-i mübāreke (F; KOHD) & Ms.or.fol. 4052 \\
\hline
\end{tabular}


The Manuscripts Rescher Sold to the Berlin State Library (Reşer'in Berlin Devlet Kütüphanesi'ne Sattığı Yazmalar)

\begin{tabular}{|c|c|c|c|}
\hline Nr. & $\begin{array}{l}\text { Date } \\
\text { Tarih }\end{array}$ & $\begin{array}{c}\text { Name of Work, Name of Author (Language; Catalogue } \\
\text { Information) } \\
\text { Eser adı, Müellif adı (Dil; Katalog Bilgisi) }\end{array}$ & $\begin{array}{l}\text { Shelf nr. } \\
\text { Raf nr. }\end{array}$ \\
\hline 556. & 04.11 .1926 & Kitāb-ı Fütüvvet-nāme (A; 17B/2, 94) & Ms.or.oct. 2319 \\
\hline 557. & 04.11 .1926 & Dīvān, Hāāız Nūrī (T; 13/5, 220) & Ms.or.fol. 4114 \\
\hline 558. & 04.11 .1926 & Cevher-i nigīn, 'Alī (T; 13/5, 277) & Ms.or.fol. 4110 \\
\hline 559. & 04.11 .1926 & Manțıu'ț-țayr, Aḥmed et-Toḳadī (T; 13/4, 349) & Ms.or.oct. 2435 \\
\hline 560. & 04.11 .1926 & $\begin{array}{l}\text { 1. Mecmū 'a-i eş 'ār (T; 13/2, 293) } \\
\text { 2. Berber-nāme, Sāābit 'Alā'eddīn Efendi (T; 13/2, 542) } \\
\text { 3. Hikāye-i Hoca Fesād, Sāābit 'Alā'eddīn Efendi (T; 13/2, 550) } \\
\text { 4. Gül-i nevres, Yahyā (T; UC) }\end{array}$ & Ms.or.oct. 2367 \\
\hline 561. & 04.11 .1926 & $\begin{array}{c}\text { Nāmık Kemāl'in eserlerinden seçmeler [Selected works of } \\
\text { Namık Kemal] (T; 13/2, 278) }\end{array}$ & Ms.or.oct. 2368 \\
\hline 562. & 04.11 .1926 & Mecmū'a-i inşā' '(T; 13/4, 298) & Ms.or.oct. 2366 \\
\hline 563. & 04.11 .1926 & Mecmū a-i eş 'är ve fevā'id (T; UC) & Ms.or.fol. 4090 \\
\hline 564. & 04.11 .1926 & el-Mühezzzeb, İbnü’n-Nefĩs (A; 17A/1, 56) & Ms.or.oct. 2365 \\
\hline 565. & 04.11 .1926 & 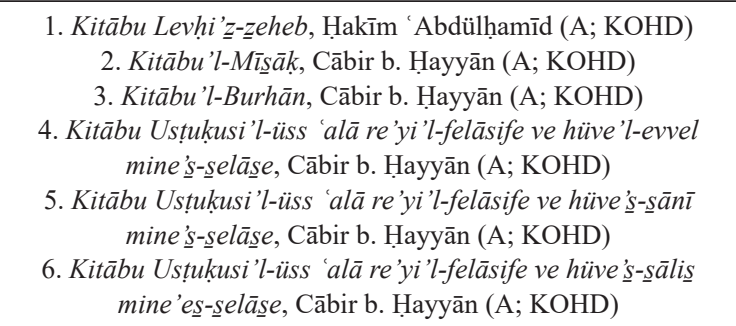 & Ms.or.oct. 2250 \\
\hline 566. & 04.11 .1926 & Taḳvīm-i lāle, Meḥmed 'Işḳi (T; 13/5, 292) & Ms.or.quart. 1548 \\
\hline 567. & 04.11 .1926 & $\operatorname{Tefsir}(\mathrm{T} ; 13 / 5,3)$ & Ms.or.quart. 1585 \\
\hline 568. & 04.11 .1926 & Enfesü'l-cevāhir, Ebu'l-Fażl Mūsā İzniḳ̄i (T; 13/5, 1) & Ms.or.quart. 1544 \\
\hline 569. & 04.11 .1926 & Tuhfe-i ra 'nā, Maẓlūmī (T; 13/4, 494) & Ms.or.oct. 2430 \\
\hline 570. & 04.11 .1926 & Kenzü'd-dakā'ık fi'l-fürū', Ebu'l-Berekāt en-Nesefĩ (A; KOHD) & Ms.or.oct. 2431 \\
\hline 571. & 04.11 .1926 & Tārīh-i Miṣr $(\mathrm{T} ; 13 / 1,90)$ & Ms.or.fol. 4091 \\
\hline 572. & 04.11 .1926 & $\begin{array}{c}\text { el-Menhecü'l-kavī fì Şerhi'l-Mesnevī, Yūsuf b. Aḥmed el- } \\
\text { Mevlevī (A-F; KOHD), } 6 \text { c. [vols.] }\end{array}$ & Ms.or.quart. 1511 \\
\hline 573. & 04.11 .1926 & $\begin{array}{l}\text { Tuhfetü'l-fāris fì aḥvāli huyūli'l-mücāhidīn, Țayyārzāde 'Ațā (T; } \\
13 / 5,191)\end{array}$ & Ms.or.fol. 4115 \\
\hline 574. & 04.11 .1926 & $\begin{array}{c}\text { Sevku'l- 'askeri'l-cedìd der 'ahd-i Sulțān Mecìd, Mușțafā Ḥāmī } \\
\text { (T; 13/1, 212) }\end{array}$ & Ms.or.fol. 4066 \\
\hline 575. & 04.11 .1926 & Düstūrü'l-inşā', Șar1 'Abdullāh Efendi ('Abdī) (T; 13/4, 273) & Ms.or.oct. 2249 \\
\hline 576. & 04.11 .1926 & $\begin{array}{c}\text { Nuhbetü't-tevārīh ve'l-ahbār, Edirnevī Meḥmed b. Meḥmed (T; } \\
13 / 1,86)\end{array}$ & Ms.or.fol. 4097 \\
\hline
\end{tabular}


The Manuscripts Rescher Sold to the Berlin State Library (Reşer'in Berlin Devlet Kütüphanesi'ne Sattığı Yazmalar)

\begin{tabular}{|c|c|c|c|}
\hline Nr. & $\begin{array}{l}\text { Date } \\
\text { Tarih }\end{array}$ & $\begin{array}{l}\text { Name of Work, Name of Author (Language; Catalogue } \\
\text { Information) } \\
\text { Eser adı, Müellif adı (Dil; Katalog Bilgisi) }\end{array}$ & $\begin{array}{l}\text { Shelf nr. } \\
\text { Raf nr. }\end{array}$ \\
\hline 577. & 04.11 .1926 & $\begin{array}{l}\text { Hulāṣatü'l-kütüb fi Şerhì'l-lübb, Muhammed b. 'Alī el-Kūnbānī } \\
\text { (A; KOHD) }\end{array}$ & Ms.or.oct. 2384 \\
\hline 578. & 04.11 .1926 & Cevāhirü'l-fikhh, Țāhir b. İslām el-Hู'ārizmī (A; KOHD) & Ms.or.quart. 1549 \\
\hline 579. & 04.11 .1926 & $\begin{array}{c}\text { el-Hayātu şerḥi Şurūṭi’ș-șalāt, Mușțafā b. Hamza el-Buluvī (A; } \\
\text { KOHD) }\end{array}$ & Ms.or.quart. 1531 \\
\hline 580. & 04.11 .1926 & Cihān-nümā, Kātib Çelebi (T; 13/5, 163) & Ms.or.fol. 4056 \\
\hline 581. & 04.11 .1926 & 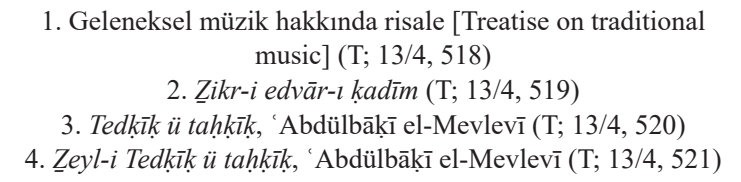 & Ms.or.oct. 2330 \\
\hline 582. & 04.11 .1926 & $\begin{array}{c}\text { ez-Zerī a ilā mekārimi ’ş-şerī 'a, el-Ḥ̈seyn b. Muhammed el- } \\
\text { Ișfahānī (A; KOHD) }\end{array}$ & Ms.or.quart. 1583 \\
\hline 583. & 28.12 .1926 & $\begin{array}{l}\text { el-Fütūhātü'l-mecīdiye li-men erāde 's-siyer ile'l-cenneti'l- 'aliye, } \\
\text { 'Oșmān b. Muhammed eț-Ṭarāblusī (A; KOHD) }\end{array}$ & Ms.or.quart. 1510 \\
\hline 584. & 28.12 .1926 & Maḥabbet-nāme-i cāvìd, Fażlullāh-1 Ḥurūfī (F; 14/1, 293) & Ms.or.oct. 2241 \\
\hline 585. & 28.12 .1926 & $\begin{array}{l}\text { Muhtașaru Mesā'ili'l-Kayșarānī, 'Ömer b. el-Ferruhān eț-Ṭaberī } \\
\text { (A; KOHD) }\end{array}$ & Ms.or.oct. 2224 \\
\hline 586. & 28.12 .1926 & $\begin{array}{c}\text { Şerhü'l-Fevā'idi'l-Gílyāśiye, Şemseddīn Muhammed el-Kirmānī } \\
\text { (A; 17A/2, 126) }\end{array}$ & Ms.or.oct. 2223 \\
\hline 587. & 28.12 .1926 & Kitābu 'Uḳūdi’l- 'ukūl, Ḥüseyn 'Alī Efendi (T; 13/4, 433) & Ms.or.oct. 2242 \\
\hline 588. & 28.12 .1926 & 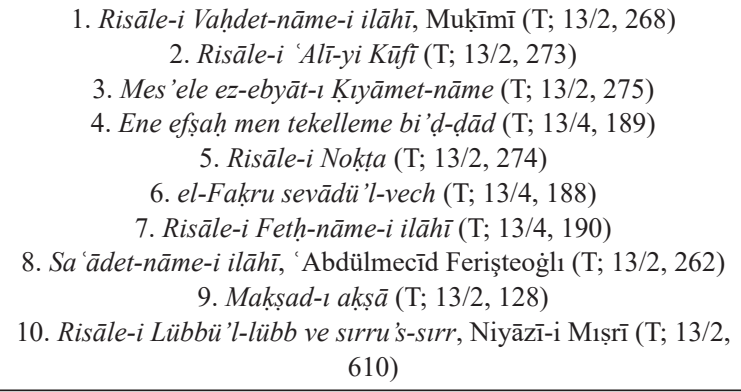 & Ms.or.oct. 2440 \\
\hline 589. & 28.12 .1926 & Gülzār-l șavāb, Nefeszāde İbrāhīm (T; 13/4, 523) & Ms.or.oct. 2222 \\
\hline 590. & 28.12 .1926 & Tevārīh-i Āl-i 'Ossmān $(\mathrm{T} ; 13 / 4,258)$ & Ms.or.oct. 2438 \\
\hline 591. & 28.12 .1926 & Vaḥdet-nāme, 'Abdurraḥimm-i Karaḥiṣārī (T; 13/2, 18) & Ms.or.oct. 2243 \\
\hline 592. & 28.12 .1926 & $\begin{array}{l}\text { 1. el-Hidāye fì i 'tikāadi ehli s'sünne ve'l-cemā 'a, Muhammed b. } \\
\text { Ebī Bekr er-Rāzī (A; KOHD) } \\
\text { 2. el-Cevheretü'l-münīfe fì şerhị Vașiyeti Ebì Hanīfe, Mullā } \\
\text { Hüüseyn (A; KOHD) }\end{array}$ & Ms.or.oct. 2436 \\
\hline 593. & 28.12 .1926 & Tevārīhl-i Āl-i 'Ossmān $(\mathrm{T} ; 13 / 4,255)$ & Ms.or.oct. 2235 \\
\hline
\end{tabular}


The Manuscripts Rescher Sold to the Berlin State Library (Reşer'in Berlin Devlet Kütüphanesi'ne Sattığı Yazmalar)

\begin{tabular}{|c|c|c|c|}
\hline Nr. & $\begin{array}{l}\text { Date } \\
\text { Tarih }\end{array}$ & $\begin{array}{c}\text { Name of Work, Name of Author (Language; Catalogue } \\
\text { Information) } \\
\text { Eser adı, Müellif adı (Dil; Katalog Bilgisi) }\end{array}$ & $\begin{array}{l}\text { Shelf nr. } \\
\text { Raf nr. }\end{array}$ \\
\hline 594. & 28.12.1926 & $\begin{array}{c}\text { Risāle bi'smi'l-Meliki'n-Nāṣır fi'r-redd 'ale'l-mu 'teriżīn } \\
\text { 'ale'ş-Şeyh Muhyiddīn İbni’l-'Arabī, Muhamamed b. Ya 'ḳūb el- } \\
\text { Fīrūzābādī (A; KOHD) }\end{array}$ & Ms.or.oct. 2225 \\
\hline 595. & 28.12 .1926 & Sefer-nāme-i hayr, Meḥmed Es'ad Efendi (T; 13/4, 231) & Ms.or.oct. 2439 \\
\hline 596. & 28.12.1926 & Fīhi mā fìhi, Mevlānā Celāleddīn-i Rūmī (F; 14/1, 181) & Ms.or.oct. 2255 \\
\hline 597. & 28.12.1926 & $\begin{array}{c}\text { el-Makssad li-telhīṣ mā fi'l-Mürşid, Zekeriyā' b. Muhammed el- } \\
\text { Enșārī (A; KOHD) }\end{array}$ & Ms.or.quart. 1589 \\
\hline 598. & 28.12.1926 & Fetāvā-yl 'Alì Efendi șag̀īr żeyli $(\mathrm{T} ; 13 / 5,111)$ & Ms.or.quart. 1586 \\
\hline 599. & 28.12.1926 & $\begin{array}{l}\text { Hāşşiye 'alā Şerhì'l-Mukaddimeti'l- 'Aşmāoviye, Aḥmed b. Türkī } \\
\text { el-Menşelīlī (A; KOHD) }\end{array}$ & Ms.or.quart. 1587 \\
\hline 600. & 28.12.1926 & Resā ìl, Kemālpaşazāde (A; UC) & Ms.or.oct. 2236 \\
\hline 601. & 28.12.1926 & Tuhfe-i Rūmī, 'Alī Sirrī Efendi (T; 13/4, 150) & Ms.or.oct. 2257 \\
\hline 602. & 28.12.1926 & 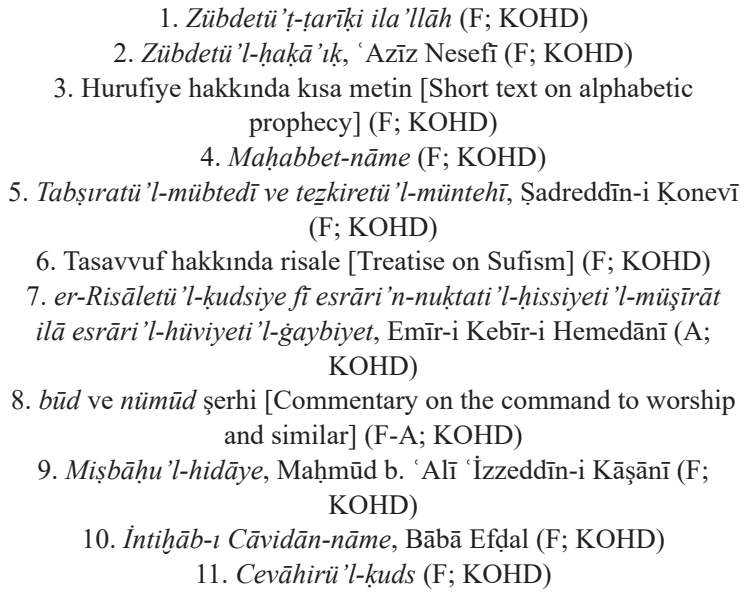 & Ms.or.oct. 2377 \\
\hline 603. & 28.12.1926 & Muhtārātü’n-nevāzil, Burhāneddīn el-Merg̀īnānī (A; KOHD) & Ms.or.oct. 2226 \\
\hline 604. & 28.12.1926 & 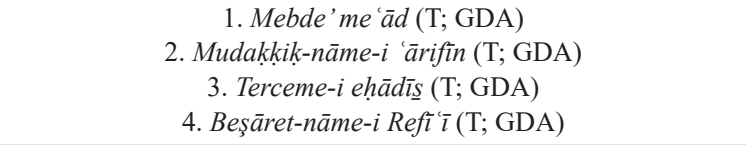 & Ms.or.oct. 2237 \\
\hline 605. & 28.12 .1926 & İlāhiyāt, 'Azīz Maḥmūd Hüdā'î (T; 13/2, 350) & Ms.or.oct. 2247 \\
\hline 606. & 28.12 .1926 & Ledün-nāme, Murādī (T; 13/2, 194) & Ms.or.oct. 2256 \\
\hline 607. & 28.12.1926 & $\begin{array}{c}\bar{A} d \bar{a} b \ddot{u} \text { 'l-menāzil, 'Abdüllațīf b. Durmuş-1 Karamanī (T; 13/2, } \\
176)\end{array}$ & Ms.or.oct. 2260 \\
\hline 608. & 28.12.1926 & (Risālet) el-İ'tilāffì vücūhi'l-iḩtilāf, Yūsufefendizāde (A; KOHD) & Ms.or.oct. 2238 \\
\hline 609. & 28.12 .1926 & Risāle fì evșāfìn-Nebī, 'Ubeydī (T; GDA) & Ms.or.oct. 2441 \\
\hline
\end{tabular}


The Manuscripts Rescher Sold to the Berlin State Library (Reşer'in Berlin Devlet Kütüphanesi'ne Sattığı Yazmalar)

\begin{tabular}{|c|c|c|c|}
\hline Nr. & $\begin{array}{l}\text { Date } \\
\text { Tarih }\end{array}$ & $\begin{array}{c}\text { Name of Work, Name of Author (Language; Catalogue } \\
\text { Information) } \\
\text { Eser adı, Müellif adı (Dil; Katalog Bilgisi) }\end{array}$ & $\begin{array}{l}\text { Shelf nr. } \\
\text { Raf nr. }\end{array}$ \\
\hline 610. & 28.12.1926 & Leylā vü Mecnūn, 'Abdurraḥmān Cāmī (F; 14/1, 173) & Ms.or.oct. 2239 \\
\hline 611. & 28.12.1926 & $\begin{array}{c}\text { Muhtașar Evżahu'l-mesālik ilā ma 'rifeti'l-buldān ve'l-memālik, } \\
\text { Sipāhīzāde Meḥmed b. 'Alī }(\mathrm{T} ; 13 / 4,342)\end{array}$ & Ms.or.oct. 2244 \\
\hline 612. & 28.12.1926 & $\begin{array}{l}\text { 1. Kur'ān'dan muhtelif ayetlerin tefsiri [Tafsir of various } \\
\text { Qur'anic verses] (F; GDA) } \\
\text { 2. Sırru'l-halāayık, Faḳrī Efendi (T; GDA) }\end{array}$ & Ms.or.oct. 2261 \\
\hline 613. & 28.12 .1926 & Şifā 'iye, Şa 'bān b. Aḥmed Şifā'̄̄ (T; 13/4, 421) & Ms.or.oct. 2442 \\
\hline 614. & 28.12 .1926 & 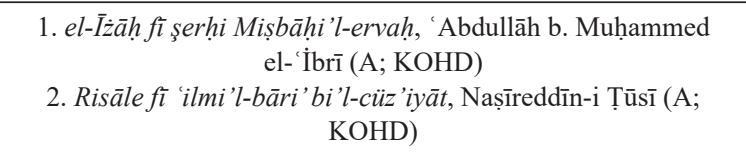 & Ms.or.oct. 2437 \\
\hline 615. & 28.12 .1926 & $\begin{array}{l}\text { Hadis ile muhtelif konulardaki mesajlar derlemesi [Compilation } \\
\text { of hadith and messages on various topic] (A; KOHD) }\end{array}$ & Ms.or.oct. 2246 \\
\hline 616. & 28.12.1926 & $\begin{array}{l}\dot{G} \bar{a} y e t \ddot{u} \text { 'l-beyān fì tedbīri bedeni l-insān, Șālị̣ b. Nașrullāh (İbn } \\
\text { Sellūm) (T; 13/5, 188) }\end{array}$ & Ms.or.quart. 1588 \\
\hline 617. & 28.12.1926 & $\begin{array}{c}\text { Tevārīh fi beyānı Moskov ve Leh ve Bosna ve Arnavudluk ve ba ż̀ } \\
\text { belde }(\mathrm{T} ; 13 / 1,317)\end{array}$ & Ms.or.fol. 4062 \\
\hline 618. & 28.12.1926 & Ferruh u Hümā $(\mathrm{T} ; 13 / 5,275)$ & Ms.or.fol. 4061 \\
\hline 619. & 28.12.1926 & 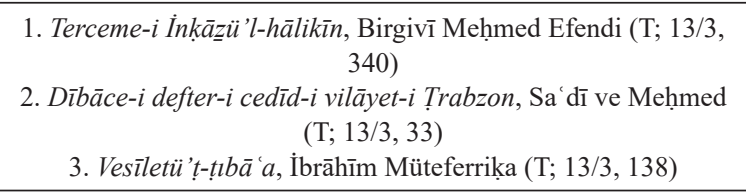 & Ms.or.oct. 2245 \\
\hline 620. & 28.12.1926 & 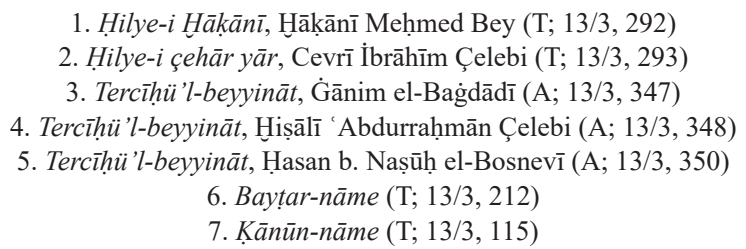 & Ms.or.oct. 2259 \\
\hline
\end{tabular}


The Manuscripts Rescher Sold to the Berlin State Library (Reşer'in Berlin Devlet Kütüphanesi'ne Sattığı Yazmalar)

\begin{tabular}{|c|c|c|c|}
\hline Nr. & $\begin{array}{l}\text { Date } \\
\text { Tarih }\end{array}$ & $\begin{array}{l}\text { Name of Work, Name of Author (Language; Catalogue } \\
\text { Information) } \\
\text { Eser adı, Müellif adı (Dil; Katalog Bilgisi) }\end{array}$ & $\begin{array}{l}\text { Shelf nr. } \\
\text { Raf nr. }\end{array}$ \\
\hline 621. & 28.12.1926 & 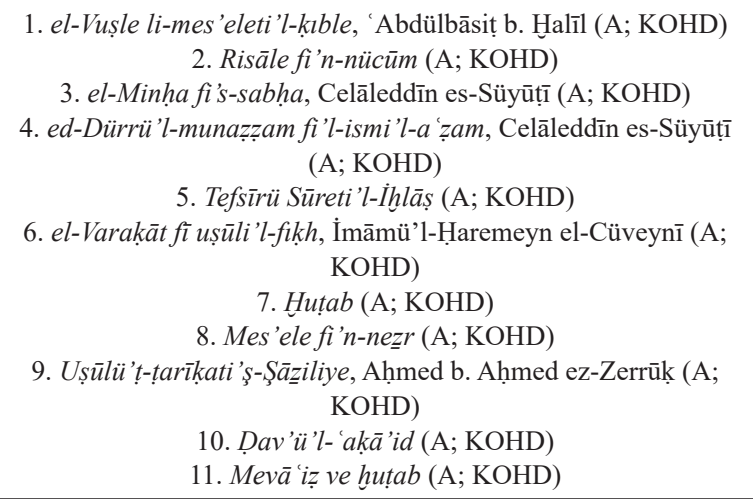 & Ms.or.oct. 2373 \\
\hline 622. & 28.12 .1926 & Münebbihāt 'ale'l-isti 'dād li-yevmi'l-me'ād (A; KOHD) & Ms.or.oct. 2375 \\
\hline 623. & 28.12.1926 & Mebāhis üüss-ṣalāt, Nuṣ̣hī Nāṣı̣ịi (T; 13/4, 46) & Ms.or.oct. 2262 \\
\hline 624. & 28.12 .1926 & İmtihāäül-ežkiyā', Birgivī Mehmed Efendi (A; 17A/2, 112) & Ms.or.oct. 2248 \\
\hline 625. & 28.12 .1926 & Nefise-i uhreviye, Kāmī Meḥmed Efendi (T; 13/4, 43) & Ms.or.oct. 2258 \\
\hline 626. & 28.12.1926 & 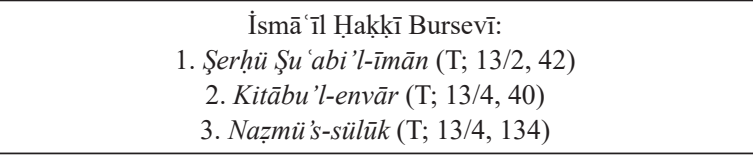 & Ms.or.oct. 2372 \\
\hline 627. & 28.12 .1926 & Zādü'l-mütezevvicīn fì şerhi Zַühri'l-müte'ehhilīn (A; 17A/2, 106) & Ms.or.oct. 2263 \\
\hline 628. & 28.12 .1926 & $\begin{array}{l}\text { Kitäbu'd-Dürri'l-munazzam fì medhi übbehet Vāsșa Paşa el- } \\
\text { mu 'azzam, İskender b. Circis el-Lübnānī (A; KOHD) }\end{array}$ & Ms.or.fol. 4055 \\
\hline 629. & 18.01.1927 & $\begin{array}{l}\text { et-Tibyān fí akssāmi 'l-Kur'ān, İbn Kayyyım el-Cevziye (A; } \\
\text { KOHD) }\end{array}$ & Ms.or.quart. 1590 \\
\hline 630. & 18.01.1927 & 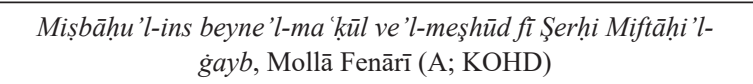 & Ms.or.fol. 4074 \\
\hline 631. & 18.01.1927 & Tefsīrü Cemāleddīn, Cemāleddīn İshāḳ-1 Ḳaramanī (A; KOHD) & Ms.or.quart. 1591 \\
\hline
\end{tabular}


The Manuscripts Rescher Sold to the Berlin State Library (Reşer'in Berlin Devlet Kütüphanesi'ne Sattığı Yazmalar)

\begin{tabular}{|c|c|c|c|}
\hline Nr. & $\begin{array}{l}\text { Date } \\
\text { Tarih }\end{array}$ & $\begin{array}{c}\text { Name of Work, Name of Author (Language; Catalogue } \\
\text { Information) } \\
\text { Eser adı, Müellif adı (Dil; Katalog Bilgisi) }\end{array}$ & $\begin{array}{l}\text { Shelf nr. } \\
\text { Raf nr. }\end{array}$ \\
\hline 632. & 18.01.1927 & 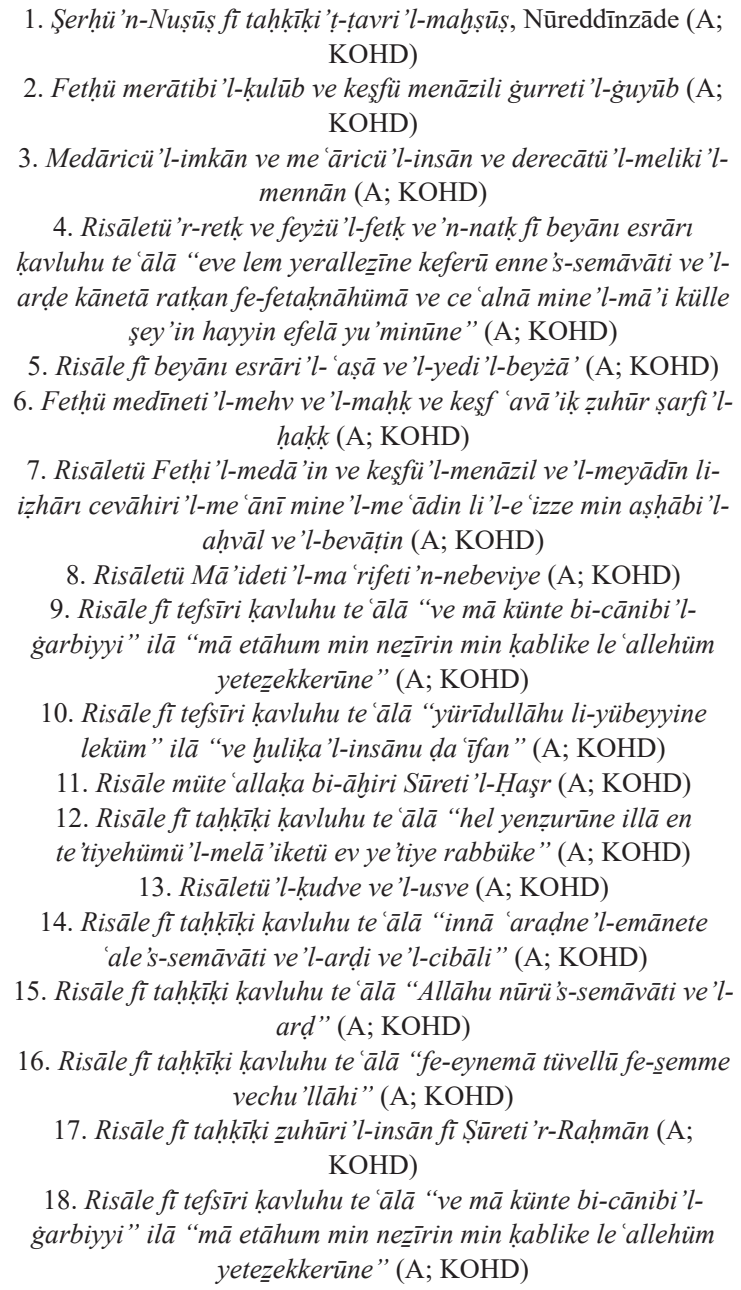 & Ms.or.oct. 2232 \\
\hline 633. & 18.01 .1927 & Risāle-i ḳudsiye, Muḥammed Pārsā (F; 14/1, 253) & Ms.or.oct. 2230 \\
\hline 634. & 18.01 .1927 & Mi ýār-l Cemālì, Şemseddīn Fahrī-i Ișfahānī (F; 14/1, 254) & Ms.or.oct. 2231 \\
\hline 635. & 18.01.1927 & 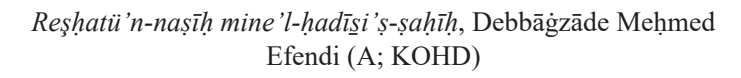 & Ms.or.oct. 2233 \\
\hline 636. & 18.01 .1927 & $\begin{array}{c}\text { Nakdü'n-nuṣūṣ fì şerhi Nakşsi'l-füșūṣ, 'Abdurraḥmān Cāmī (F-A; } \\
\text { KOHD) }\end{array}$ & Ms.or.oct. 2229 \\
\hline 637. & 18.01 .1927 & Kitābu Lețā'ifi'l-işārāt fi'l-fiḳh, Bedreddīn-i Simavī (A; KOHD) & Ms.or.fol. 4098 \\
\hline
\end{tabular}


The Manuscripts Rescher Sold to the Berlin State Library (Reşer'in Berlin Devlet Kütüphanesi'ne Sattığı Yazmalar)

\begin{tabular}{|c|c|c|c|}
\hline Nr. & $\begin{array}{l}\text { Date } \\
\text { Tarih }\end{array}$ & $\begin{array}{c}\text { Name of Work, Name of Author (Language; Catalogue } \\
\text { Information) } \\
\text { Eser adı, Müellif adı (Dil; Katalog Bilgisi) }\end{array}$ & $\begin{array}{l}\text { Shelf nr. } \\
\text { Raf nr. }\end{array}$ \\
\hline 638. & 18.01.1927 & $\begin{array}{c}\text { Tercemetü'de-Darīr ve takdimetü'z-Zahīr, Darīr (T; 13/1, 59A-D), } \\
4 \text { c. [vols.] }\end{array}$ & Ms.or.quart. 1552 \\
\hline 639. & 18.01.1927 & 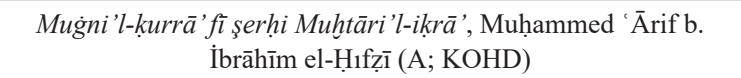 & Ms.or.oct. 2234 \\
\hline 640. & 18.01 .1927 & 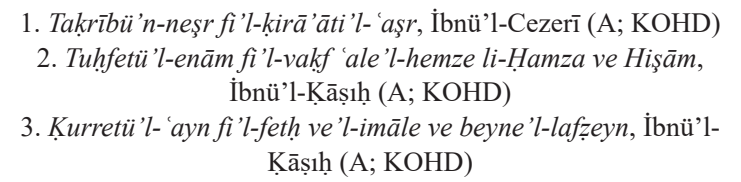 & Ms.or.oct. 2227 \\
\hline 641. & 18.01 .1927 & 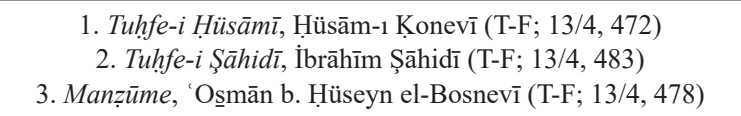 & Ms.or.oct. 2374 \\
\hline 642. & 22.01 .1927 & $\begin{array}{l}\text { 1. Hāşiye 'alā Şerḥi Hidāyeti'l-hikme, Hocazāde Muṣliheddīn } \\
\text { Efendi (A; KOHD) } \\
\text { 2. el-Ịhsās bi-kavsi kuzeh (A; KOHD) } \\
\text { 3. Hidāyetü'l-hikme (ḳ̂sm 2-3 [part 2-3]), Es̄īreddīn el-Ebherī } \\
\text { (A; KOHD) }\end{array}$ & Ms.or.oct. 2285 \\
\hline 643. & 22.01 .1927 & $\begin{array}{c}\text { Ta'rīhü hükmi'l-ümerā' eş-Şihābiyīn fì Lübnān, Hanāniyā el- } \\
\text { Müneyyer ez-Zevḳī (A; KOHD) }\end{array}$ & Ms.or.quart. 1515 \\
\hline 644. & 28.01.1927 & $\begin{array}{l}\text { el-Vakf ve'l-ibtidā', Muḥammed b. Țayfūr es-Secāvendī (A; } \\
17 \mathrm{~A} / 1,10)\end{array}$ & Ms.or.oct. 2376 \\
\hline 645. & 28.01 .1927 & Cevāhirü'l-fiḳh, Ṭāhir b. İslām el-Hูaārizmī (A; KOHD) & Ms.or.oct. 2264 \\
\hline 646. & 28.01.1927 & el-İtilāffì vücūhi'l-ihtilāff, Yūsufefendizāde (A; KOHD) & Ms.or.quart. 1593 \\
\hline 647. & 28.01 .1927 & Kitābu'ş-Şemā 'il, et-Tirmiz̄ī (A; KOHD) & Ms.or.oct. 2380 \\
\hline 648. & 28.01.1927 & $\begin{array}{c}\text { el-Fevā'idü's-Senhūriye fì Şerhì'l-Cezeriye, 'Alī b. Hasan es- } \\
\text { Senhūrī (A; KOHD) }\end{array}$ & Ms.or.oct. 2381 \\
\hline 649. & 28.01 .1927 & $\begin{array}{l}\text { Şerhü Risāleti’l-isti 'āre, Karatepeli Ḥüseyn b. Mușțafā (A; } \\
\text { 17A/2, 127) }\end{array}$ & Ms.or.oct. 2265 \\
\hline 650. & 28.01.1927 & el-Müfìd, 'Abdurraḥmān 'Abdī Paşa (T; 13/2, 615) & Ms.or.oct. 2267 \\
\hline 651. & 28.01.1927 & Tuhfetü'l-mecānīn, Lebīb Meḥmed Efendi (T; 13/2, 225) & Ms.or.oct. 2386 \\
\hline 652. & 28.01 .1927 & Tesviyetü'l-büyūt, Kethudā-yı 'Atțārāt 'Al̄̄ Efendi (T; 13/4, 366) & Ms.or.oct. 2268 \\
\hline 653. & 28.01.1927 & Uknūmü'l-lugiat (F-T; KOHD) & Ms.or.oct. 2383 \\
\hline 654. & 28.01.1927 & Terceme-i Gülistān (T; 13/4, 558) & Ms.or.oct. 2385 \\
\hline 655. & 28.01.1927 & $\begin{array}{c}\text { ez-ZZehebü'l-müzzāb fi meżāhibi'n-nuḥāt ve dikkati'l-i 'rāb, Yūsuf } \\
\text { b. Hamza eş-Şehrezūrī (A; KOHD) }\end{array}$ & Ms.or.oct. 2382 \\
\hline
\end{tabular}


The Manuscripts Rescher Sold to the Berlin State Library (Reşer'in Berlin Devlet Kütüphanesi'ne Sattığı Yazmalar)

\begin{tabular}{|c|c|c|c|}
\hline Nr. & $\begin{array}{l}\text { Date } \\
\text { Tarih }\end{array}$ & $\begin{array}{c}\text { Name of Work, Name of Author (Language; Catalogue } \\
\text { Information) } \\
\text { Eser adı, Müellif adı (Dil; Katalog Bilgisi) }\end{array}$ & $\begin{array}{l}\text { Shelf nr. } \\
\text { Raf nr. }\end{array}$ \\
\hline 656. & 28.01 .1927 & 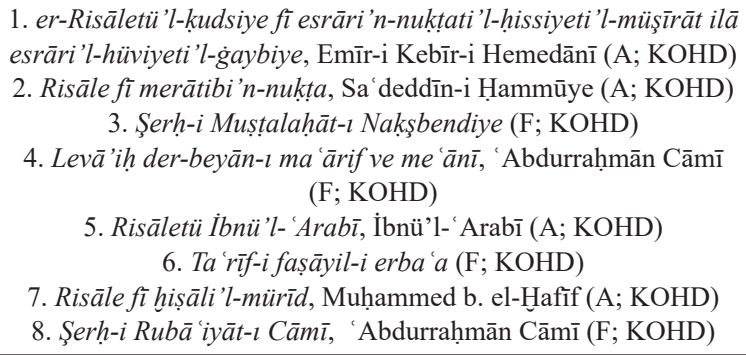 & Ms.or.oct. 2379 \\
\hline 657. & 28.01.1927 & $\begin{array}{l}\text { Tezzkiretü's-selāṭinn, Maḥmūd Mīrzā b. Fetḥ 'Alī Şāh Kạācār (F; } \\
14 / 1,273)\end{array}$ & Ms.or.oct. 2266 \\
\hline 658. & 28.01 .1927 & Terceme-i Eşref, Meḥmed S̄āḳıb (T; 13/4, 430) & Ms.or.oct. 2269 \\
\hline 659. & 28.01 .1927 & Işs-nāme, Șafī Rūşen̄̄ (T; 13/2, 436) & Ms.or.oct. 2270 \\
\hline 660. & 28.01 .1927 & 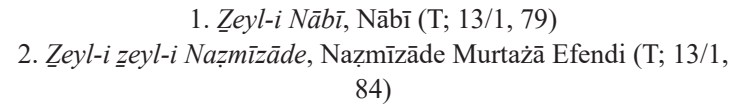 & Ms.or.oct. 2271 \\
\hline 661. & 28.01.1927 & $\begin{array}{l}\text { 1. Münşe'āt, Nābī (T; 13/4, 289) } \\
\text { 2. Münşe'āt mecmū 'ast }(\mathrm{T} ; 13 / 4,297)\end{array}$ & Ms.or.oct. 2272 \\
\hline 662. & 28.01.1927 & Dìvān, Hoca Neş'et (T; 13/2, 408) & Ms.or.oct. 2273 \\
\hline 663. & 28.01 .1927 & 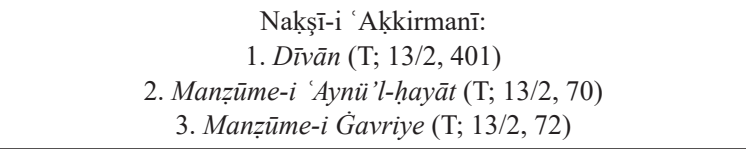 & Ms.or.oct. 2274 \\
\hline 664. & 28.01.1927 & Kemāliye $(\mathrm{T} ; 13 / 5,190)$ & Ms.or.quart. 1519 \\
\hline 665. & 28.01.1927 & Muhtașaru't-țbb (T; 13/3, 198) & Ms.or.fol. 4099 \\
\hline 666. & 28.01.1927 & 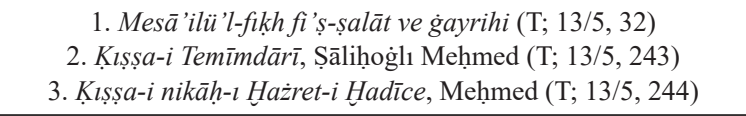 & Ms.or.quart. 1550 \\
\hline 667. & 28.01 .1927 & Mukatța àt, Faḩreddīn Maḥmūd b. Yemīn (F; 14/1, 30) & Ms.or.oct. 2275 \\
\hline 668. & 13.04.1927 & $\begin{array}{l}\text { Cevāhir-i fevāhir-i Mesnevī, Șarı 'Abdullāh Efendi ('Abdī) (T; } \\
13 / 2,636)\end{array}$ & Ms.or.quart. 1748 \\
\hline 669. & 13.04.1927 & $\begin{array}{l}\text { 1. Zübdetü'l- 'avārlffì 'ilmi'l-ma 'ārif (T; 13/4, 162) } \\
\text { 2. Mir'âtü'l- 'avālim, Mușțafā 'Ālī (T; 13/4, 328A) }\end{array}$ & Ms.or.oct. 2514 \\
\hline 670. & 13.04 .1927 & Kelīle ve Dimne $(\mathrm{T} ; 13 / 1,437)$ & Ms.or.quart. 1747 \\
\hline 671. & 13.04.1927 & $\begin{array}{c}\text { Cāmi 'ü'l-fetāvā, Kurḳ Emre Meḥmed b. Muṣțafā el-Hamīdī (A; } \\
\text { KOHD) }\end{array}$ & Ms.or.oct. 3065 \\
\hline 672. & 13.04 .1927 & $\begin{array}{l}\text { Nālī Meḥmed b. 'Oșmān: } \\
\text { 1. Miftāhl-l heft kān }(\mathrm{T} ; 13 / 2,200) \\
\text { 2. Tuḥfe-i emsāal }(\mathrm{T} ; 13 / 2,524)\end{array}$ & Ms.or.oct. 3066 \\
\hline
\end{tabular}


The Manuscripts Rescher Sold to the Berlin State Library (Reşer'in Berlin Devlet Kütüphanesi'ne Sattığı Yazmalar)

\begin{tabular}{|c|c|c|c|}
\hline Nr. & $\begin{array}{l}\text { Date } \\
\text { Tarih }\end{array}$ & $\begin{array}{c}\text { Name of Work, Name of Author (Language; Catalogue } \\
\text { Information) } \\
\text { Eser adı, Müellif adı (Dil; Katalog Bilgisi) }\end{array}$ & $\begin{array}{c}\text { Shelf nr. } \\
\text { Raf nr. }\end{array}$ \\
\hline 673. & 13.04 .1927 & Dīvān, İsmā îl Ḥaḳkī Bursevī (T; 13/2, 356) & Ms.or.oct. 2515 \\
\hline 674. & 13.04.1927 & Dìvān, Muḥammed Şīrīn-i Mag̉ribī (F; 14/1, 373) & Ms.or.oct. 2516 \\
\hline 675. & 13.04.1927 & $\begin{array}{c}\text { Münīf Muștafā Efendi: } \\
\text { 1. Dīvān }(\mathrm{T} ; 13 / 4,27) \\
\text { 2. Zafer-nāme-i feth-i Belgrad }(\mathrm{T} ; 13 / 4,239) \\
\text { 3. Münşe' } \bar{a} t(\mathrm{~T} ; 13 / 4,237) \\
\text { 287) } \\
\text { 4. İran sefaretnamesi [Memoirs of an Iranian journey] (T; 13/4, } \\
\text { 5. Hadīs-i erba 'inn }(\mathrm{T} ; 13 / 4,320)\end{array}$ & Ms.or.oct. 2517 \\
\hline 676. & 13.04.1927 & 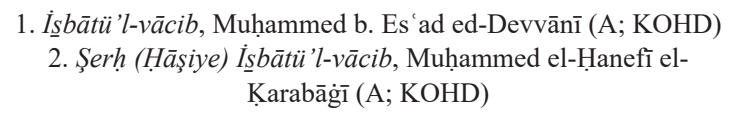 & Ms.or.oct. 3067 \\
\hline 677. & 13.04.1927 & 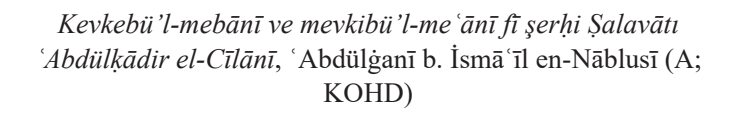 & Ms.or.oct. 2518 \\
\hline 678. & 13.04.1927 & 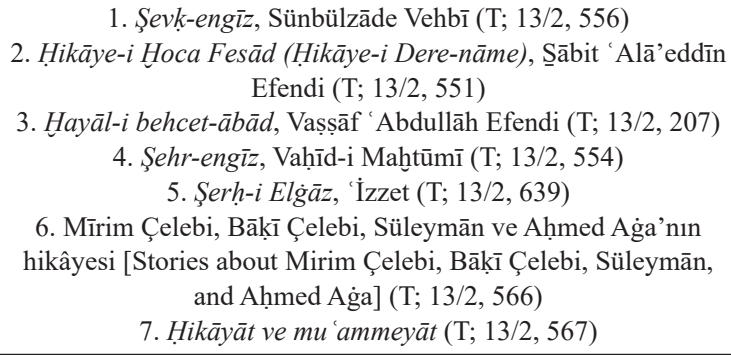 & Ms.or.oct. 2519 \\
\hline 679. & 13.04 .1927 & $\begin{array}{l}\text { Kānī: } \\
\text { 1. Münşe 'āt-ı Kānī }(\mathrm{T} ; 13 / 4,282) \\
\text { 2. Dīvān }(\mathrm{T} ; 13 / 2,379)\end{array}$ & Ms.or.oct. 2520 \\
\hline 680. & 13.04.1927 & Yūsuf u Züleyḩā, Kemālpaşazāde (T; 13/2, 518) & Ms.or.oct. 2521 \\
\hline 681. & 13.04.1927 & 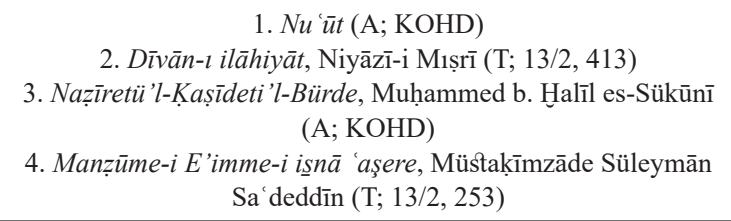 & Ms.or.oct. 2522 \\
\hline 682. & 13.04.1927 & Şerh-i Pend-i 'Ațtāar, İsmā'̄il Haḳk̄̄ Bursevī (T; 13/2, 617) & Ms.or.oct. 2523 \\
\hline 683. & 13.04.1927 & $\begin{array}{l}\text { 1. en-Nukāye muhtașaru'l-Vikāaye, 'Ubeydullāh b. Mes 'ūd el- } \\
\text { Maḥūbī (A; KOHD) } \\
\text { 2. Risāle-i Sülūk, Dervīş 'Abdullāh-1 Kaşgarīî (F; KOHD) } \\
\text { 3. Mecmū'a-i eş 'ār (F-Ç; KOHD) }\end{array}$ & Ms.or.oct. 2524 \\
\hline 684. & 13.04.1927 & Miftāḥu'l- 'ulūm, 'Alī b. Meḥmed İzmirī (T; 13/4, 35) & Ms.or.oct. 2525 \\
\hline
\end{tabular}


The Manuscripts Rescher Sold to the Berlin State Library (Reşer'in Berlin Devlet Kütüphanesi'ne Sattığı Yazmalar)

\begin{tabular}{|c|c|c|c|}
\hline Nr. & $\begin{array}{l}\text { Date } \\
\text { Tarih }\end{array}$ & $\begin{array}{c}\text { Name of Work, Name of Author (Language; Catalogue } \\
\text { Information) } \\
\text { Eser adı, Müellif adı (Dil; Katalog Bilgisi) }\end{array}$ & $\begin{array}{l}\text { Shelf nr. } \\
\text { Raf nr. }\end{array}$ \\
\hline 685. & 13.04.1927 & 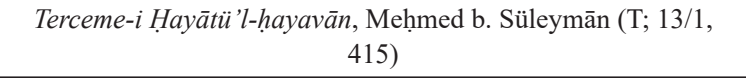 & Ms.or.quart. 1603 \\
\hline 686. & 13.04.1927 & $\begin{array}{c}\text { el-Mukaddimetü'l-Gazneviye fi'l- 'ibādāt 'alā mezhebi'l-İmām } \\
\text { Ebì Hanīfe, Aḥmed b. Muḥammed el-Ġaznevī (A; KOHD) }\end{array}$ & Ms.or.oct. 3068 \\
\hline 687. & 13.04.1927 & $\begin{array}{l}\text { el-Fetāve'l-Hayriye li-nef'i'l-beriye, Hayreddīn b. Ahmed er- } \\
\qquad \text { Remlī (A; KOHD) }\end{array}$ & Ms.or.quart. 1604 \\
\hline 688. & 13.04.1927 & $\begin{array}{l}\text { Terceme-i Kitābu Behceti'l-esrār ve lem 'ati'l-envār, Hoca } \\
\text { Sa deddīn }(\mathrm{T} ; 13 / 4,148)\end{array}$ & Ms.or.oct. 2526 \\
\hline 689. & 13.04.1927 & 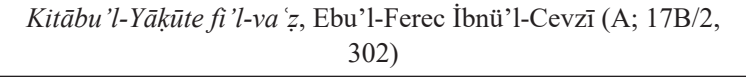 & Ms.or.oct. 2527 \\
\hline 690. & 13.04.1927 & 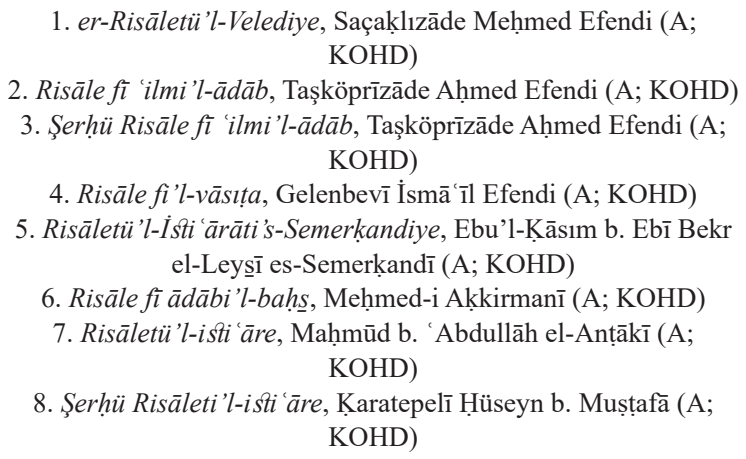 & Ms.or.oct. 2528 \\
\hline 691. & 13.04 .1927 & Enīsü’l-ḳulūb, Mușțafā 'Ālī (T; 13/5, 279) & Ms.or.quart. 1749 \\
\hline 692. & 13.04 .1927 & 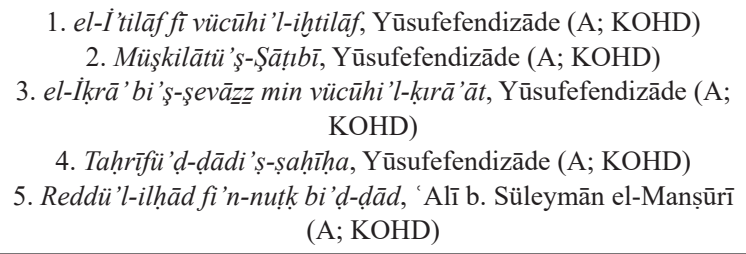 & Ms.or.oct. 2529 \\
\hline 693. & 13.04.1927 & $\begin{array}{l}\text { 1. Muhtașar-ı Dürr-i meknūn }(\mathrm{T} ; 13 / 4,334) \\
\text { 2. İslam'ın emrettiği vazifeler [Duties commanded by Islam] (T; } \\
13 / 4,59)\end{array}$ & Ms.or.oct. 2530 \\
\hline 694. & 13.04.1927 & $\begin{array}{c}\text { Cevāhirü'l- 'ikyān fì şerhì 'Umdeti'l- 'irfān, Hamdullāh b. } \\
\text { Hayreddīn (T; 13/3, 10) }\end{array}$ & Ms.or.oct. 3069 \\
\hline 695. & 13.04.1927 & $\begin{array}{l}\text { 1. Bāb vakf Hamza ve Hişām 'ale’l-hemze (A; KOHD) } \\
\text { 2. el-Käfi fì kirā'āti s-seb 'a, Muhammed b. Şürayh er-Ru'aynī } \\
\text { (A; KOHD) }\end{array}$ & Ms.or.oct. 3070 \\
\hline 696. & 13.04.1927 & Dìvān, 'İzzet 'Alī Paşa (T; 13/2, 373) & Ms.or.oct. 2531 \\
\hline
\end{tabular}


The Manuscripts Rescher Sold to the Berlin State Library (Reşer'in Berlin Devlet Kütüphanesi'ne Sattığı Yazmalar)

\begin{tabular}{|c|c|c|c|}
\hline Nr. & $\begin{array}{l}\text { Date } \\
\text { Tarih }\end{array}$ & $\begin{array}{c}\text { Name of Work, Name of Author (Language; Catalogue } \\
\text { Information) } \\
\text { Eser adı, Müellif adı (Dil; Katalog Bilgisi) }\end{array}$ & $\begin{array}{l}\text { Shelf nr. } \\
\text { Raf nr. }\end{array}$ \\
\hline 697. & 13.04 .1927 & 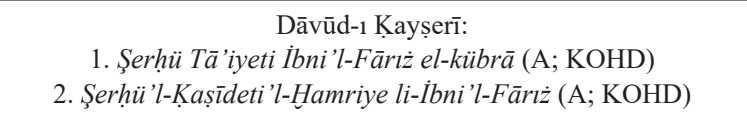 & Ms.or.oct. 2532 \\
\hline 698. & 09.05 .1927 & $\begin{array}{l}\text { Şerḥü Füsūssi 'l-hikem ve hușūsi 'l-kelām, 'Abdurrahmān Cāmī } \\
\text { (A; KOHD) }\end{array}$ & Ms.or.oct. 2534 \\
\hline 699. & 09.05 .1927 & 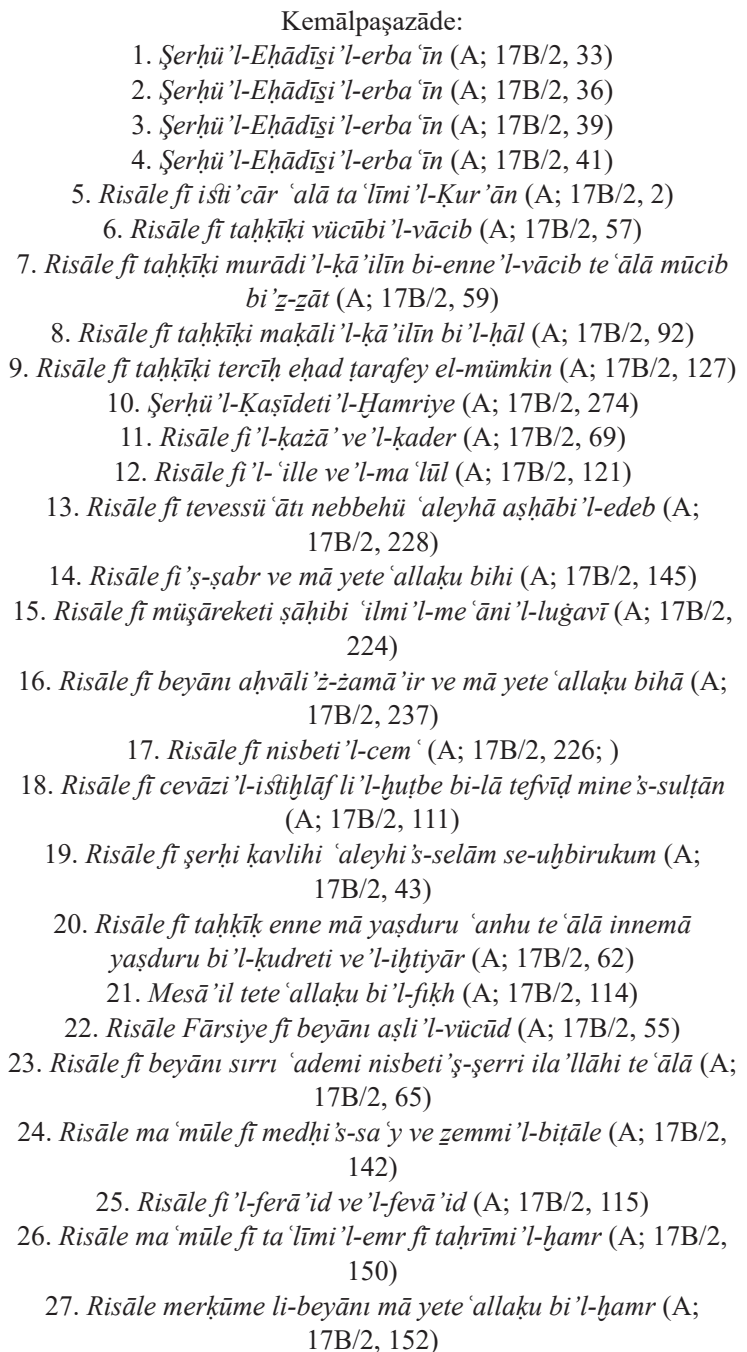 & Ms.or.oct. 2535 \\
\hline
\end{tabular}


The Manuscripts Rescher Sold to the Berlin State Library (Reșer'in Berlin Devlet Kütüphanesi'ne Sattığı Yazmalar)

\begin{tabular}{|c|c|c|c|}
\hline Nr. & $\begin{array}{l}\text { Date } \\
\text { Tarih }\end{array}$ & $\begin{array}{l}\text { Name of Work, Name of Author (Language; Catalogue } \\
\text { Information) } \\
\text { Eser adı, Müellif adı (Dil; Katalog Bilgisi) }\end{array}$ & $\begin{array}{c}\text { Shelf nr. } \\
\text { Raf nr. }\end{array}$ \\
\hline 699. & 09.05 .1927 & 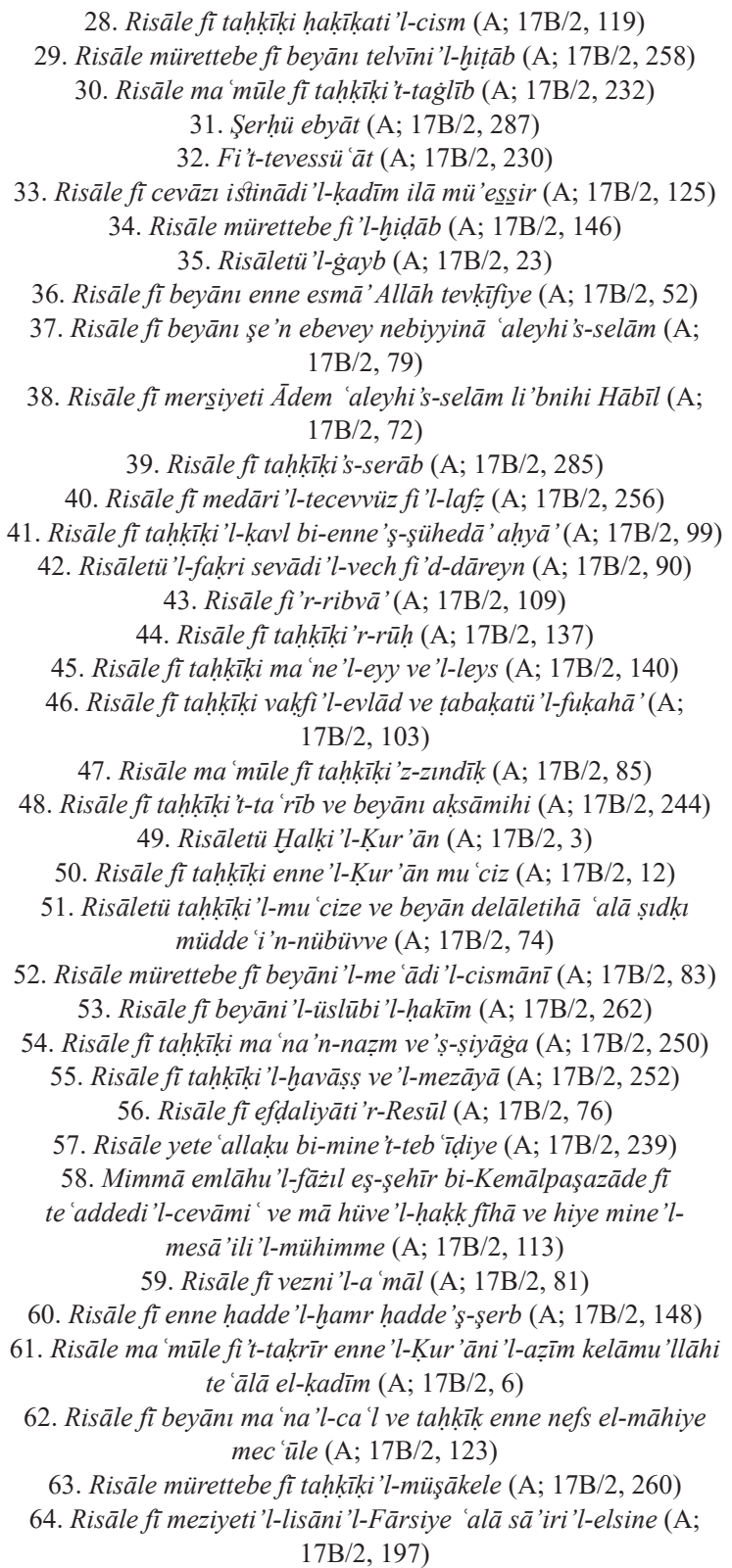 & Ms.or.oct. 2535 \\
\hline
\end{tabular}


The Manuscripts Rescher Sold to the Berlin State Library (Reşer'in Berlin Devlet Kütüphanesi'ne Sattığı Yazmalar)

\begin{tabular}{|c|c|c|c|}
\hline Nr. & $\begin{array}{l}\text { Date } \\
\text { Tarih }\end{array}$ & $\begin{array}{c}\text { Name of Work, Name of Author (Language; Catalogue } \\
\text { Information) } \\
\text { Eser adı, Müellif adı (Dil; Katalog Bilgisi) }\end{array}$ & $\begin{array}{l}\text { Shelf nr. } \\
\text { Raf nr. }\end{array}$ \\
\hline 699. & 09.05 .1927 & 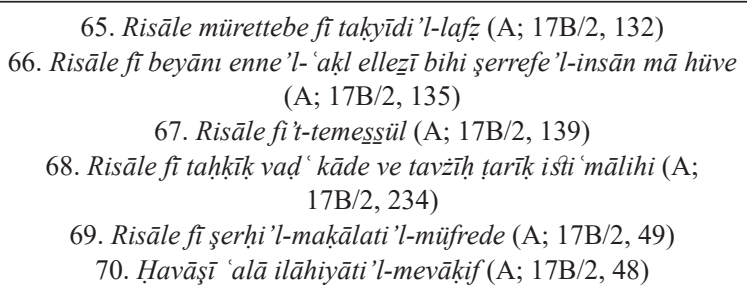 & Ms.or.oct. 2535 \\
\hline 700. & 09.05 .1927 & 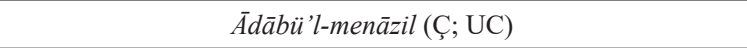 & Ms.or.oct. 2536 \\
\hline 701. & 09.05 .1927 & Kitābu'l-Aḥkām, Sehl b. Bişr (A; KOHD) & Ms.or.oct. 3072 \\
\hline 702. & 09.05 .1927 & $\begin{array}{l}\text { Aḥkāmü'l-a vām, 'Alā'eddīn 'Alī Şāh b. Muhammed el-Ḩ̌ārizmī } \\
\text { (F; KOHD) }\end{array}$ & Ms.or.oct. 2537 \\
\hline 703. & 09.05 .1927 & $\begin{array}{c}\text { Lețā 'ifǘl-kelām fì ahkāmi 'l-a vām, Muhammed el-Hüseynī } \\
\text { Seyyid Müneccim (F; 14/1, 272) }\end{array}$ & Ms.or.oct. 2538 \\
\hline 704. & 09.05 .1927 & Teshīl-i zīc-i Kasīnī, İbrāhīm Bey (T; GDA) & Ms.or.oct. 2539 \\
\hline 705. & 09.05 .1927 & Sirācü'l-mușallī (A; KOHD) & Ms.or.oct. 2540 \\
\hline 706. & 09.05 .1927 & $\begin{array}{l}\text { 1. Reml hakkında metin [Text on fortune telling with sand] (A; } \\
\text { KOHD) } \\
\text { 2. Reml hakkında metin [Text on fortune telling with sand] (A; } \\
\text { KOHD) } \\
\text { 3. Reml hakkında metin [Text on fortune telling with sand] (A; } \\
\text { KOHD) } \\
\text { 4. Reml hakkında metin [Text on fortune telling with sand] (A; } \\
\text { KOHD) } \\
\text { 5. Sirru'l-esrārr, Ebū Bekr er-Rāzì (A; KOHD) } \\
\text { 6. Reml tarifleri [Descriptions of sand fortune telling] (A; } \\
\text { KOHD) } \\
\text { 7. (T; UC) } \\
\text { KOHD) } \\
\text { 8. Mir'ätü'l- 'acā' 'ib, Ebū 'Abdillāh Muhammed b. el-Mihtār (A; } \\
\text { 9. er-Risāletü'l-bahriye fi șan 'ati'l-ilāhiye ve'l-hikemi'r- } \\
\text { rabbāniye, Muhammed Emīn 'Ārif el-Kureşì (A; KOHD) } \\
\text { 10. (T; UC) } \\
\text { 11. Reml hakkında metin [Text on fortune telling with sand] (A; } \\
\text { KOHD) }\end{array}$ & Ms.or.oct. 2651 \\
\hline 707. & 09.05 .1927 & $\begin{array}{l}\text { 1. Risāle-i Cefr (T; GDA) } \\
\text { 2. Sāmūr-ı Hindī (T; GDA) } \\
\text { 3. Rūz-nāme (T; GDA) }\end{array}$ & Ms.or.oct. 3073 \\
\hline 708. & 09.05 .1927 & Rumūzü'l-künūz, İlyās b. 'Īsā Aḳhișārī (T; 13/4, 369) & Ms.or.oct. 2541 \\
\hline
\end{tabular}


The Manuscripts Rescher Sold to the Berlin State Library (Reşer'in Berlin Devlet Kütüphanesi'ne Sattığı Yazmalar)

\begin{tabular}{|c|c|c|c|}
\hline Nr. & $\begin{array}{l}\text { Date } \\
\text { Tarih }\end{array}$ & $\begin{array}{c}\text { Name of Work, Name of Author (Language; Catalogue } \\
\text { Information) } \\
\text { Eser adı, Müellif adı (Dil; Katalog Bilgisi) }\end{array}$ & $\begin{array}{l}\text { Shelf nr. } \\
\text { Raf nr. }\end{array}$ \\
\hline 709. & 09.05 .1927 & 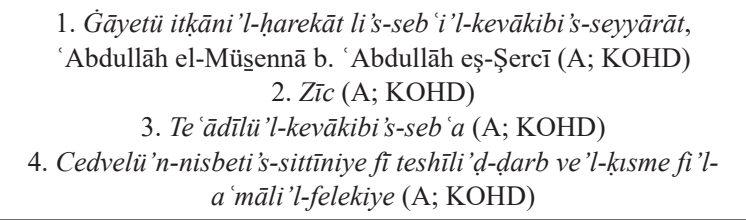 & Ms.or.oct. 2542 \\
\hline 710. & 08.06 .1927 & Cevāhirü'l-aḩbār, Ḳāsım b. eş-Şeyh 'Īsā eş-Şeybānīi (T; 13/1, & Ms.or.quart. 1607 \\
\hline 711. & 08.06 .1927 & $\begin{array}{l}\text { 1. Dürretü'l-fetāvā, Aḥmed b. Muhammed el-Mostarī (A; } \\
\text { KOHD) } \\
\text { 2. Risāletü's-sürūr ve'l-ferah, Saçaḳlızāde Mehmed Efendi (A; } \\
\text { KOHD) }\end{array}$ & Ms.or.quart. 1608 \\
\hline 712. & 08.06 .1927 & $\begin{array}{c}\text { Nūrü'l- 'ayn fì ıșlāḥi Cāmi ì’l-fuṣūleyn, Nişāncızāde Muḥyiddīn } \\
\text { Meḥmed (A; KOHD) }\end{array}$ & Ms.or.oct. 2543 \\
\hline 713. & 08.06 .1927 & et-Tevşīh 'ale 'l-Cāmi 'i’ṣ-șaḥịh, Celāleddīn es-Süyūțî (A; KOHD) & Ms.or.quart. 1609 \\
\hline 714. & 08.06 .1927 & $\begin{array}{l}\text { 1. Ta 'līkü'd-dürreti'ş-Şenevāniye 'alā şerhi'l-Ācurrūmiye fì } \\
\text { 'ilmi'l-'Arabiye, Ebū Bekr b. İsmā îl eş-Şenevānī (A; KOHD) } \\
\text { 2. Hāşsiye 'alā şerhịi'l-Ecrūmiye, el-Hamevī (A; KOHD) }\end{array}$ & Ms.or.oct. 2544 \\
\hline 715. & 08.06 .1927 & Dīvān, Kāmī Meḥmed Efendi (T; 13/2, 378) & Ms.or.oct. 2652 \\
\hline 716. & 08.06 .1927 & $\begin{array}{l}\text { Meḥmed Șādı̣ Erzincānī: } \\
\text { 1. Risāle-i Terbiye-nāme }(\mathrm{T} ; 13 / 3,68) \\
\text { 2. Risāle-i Ma 'rifetü'n-nefs }(\mathrm{T} ; 13 / 3,70) \\
\text { 3. Risāle-i Merḡūb }(\mathrm{T} ; 13 / 3,66)\end{array}$ & Ms.or.oct. 3080 \\
\hline 717. & 08.06 .1927 & $\begin{array}{l}\text { Çiğneme organları ve işlevleri, sindirim ve metabolik organlar } \\
\text { hakkında metin [Text on mastication organs and their functions, } \\
\text { digestive and metabolic organs] }(\mathrm{T} ; 13 / 4,409)\end{array}$ & Ms.or.oct. 2545 \\
\hline 718. & 08.06 .1927 & 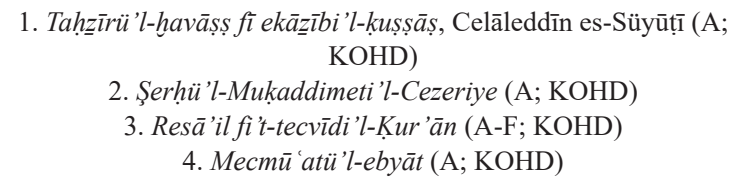 & Ms.or.oct. 2546 \\
\hline 719. & 08.06 .1927 & Tārīh-i Enverī, Sa dullāh Enverī (T; 13/4, 230) & Ms.or.oct. 2547 \\
\hline 720. & 08.06 .1927 & 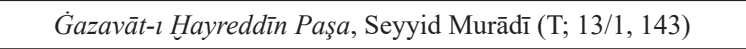 & Ms.or.quart. 1751 \\
\hline 721. & 08.06 .1927 & $\begin{array}{l}\text { Şerhü'l-Ezheriye fì 'ilmi'l- 'Arabiye, Ḩālid b. 'Abdullāh el-Ezherī } \\
\text { (A; KOHD) }\end{array}$ & Ms.or.oct. 2548 \\
\hline 722. & 08.06 .1927 & $\begin{array}{l}\text { Hāadi'l-ervāh ilā bilādi'l-efrāh, İbn Kayyım el-Cevziye (A; } \\
\text { KOHD) }\end{array}$ & Ms.or.quart. 1610 \\
\hline 723. & 08.06 .1927 & Tarīkat-nāme, Eşrefog̉ı Rūmī (T; 13/3, 75) & Ms.or.oct. 3081 \\
\hline 724. & 25.06.1927 & Mecmū a-i eş 'ār ve fevā'id (T-A; UC-GDA) & Ms.or.quart. 1611 \\
\hline
\end{tabular}


The Manuscripts Rescher Sold to the Berlin State Library (Reşer'in Berlin Devlet Kütüphanesi'ne Sattığı Yazmalar)

\begin{tabular}{|c|c|c|c|}
\hline Nr. & $\begin{array}{l}\text { Date } \\
\text { Tarih }\end{array}$ & $\begin{array}{c}\text { Name of Work, Name of Author (Language; Catalogue } \\
\text { Information) } \\
\text { Eser adı, Müellif adı (Dil; Katalog Bilgisi) }\end{array}$ & $\begin{array}{l}\text { Shelf nr. } \\
\text { Raf nr. }\end{array}$ \\
\hline 725. & 25.06 .1927 & $\begin{array}{l}\text { Terceme-i Kitābu'l-Harāc, Rodosīzāde Mehmed b. Meḥmed (T; } \\
\text { 13/4, 70) }\end{array}$ & Ms.or.oct. 2549 \\
\hline 726. & 25.06.1927 & Münşe 'āt, Ahmed Süheylī (T; 13/3, 146) & Ms.or.oct. 2550 \\
\hline 727. & 25.06 .1927 & Śbātü'l- 'ācizīn, Șūfì Allāhyār (T; 13/4, 536) & Ms.or.quart. 1752 \\
\hline 728. & 25.06.1927 & Tevārīhl-i Āl-i 'Oșmān $(\mathrm{T} ; 13 / 1,124)$ & Ms.or.quart. 1753 \\
\hline 729. & 25.06 .1927 & $\begin{array}{c}\text { Fütūhü̈l-mücāhidīn li-tervīhi ḳulūbi'l-müşāhidīn, Lāmi 'ì Çelebi } \\
\text { (T; 13/1, 254) }\end{array}$ & Ms.or.quart. 1754 \\
\hline 730. & 25.06 .1927 & Tārīh, Küçük Çelebizāde İsmā'îl 'Āṣım (T; 13/1, 181) & Ms.or.quart. 1612 \\
\hline 731. & 25.06 .1927 & $\begin{array}{l}\text { er-Redd ve'l-intișār li-Ebī Hanīfe imāmu fukahā'i 'l-emșār, } \\
\text { Muhạammed b. Muḥammed el-Kerderī (A; KOHD) }\end{array}$ & Ms.or.oct. 2551 \\
\hline 732. & 25.06 .1927 & $\begin{array}{l}\text { 1. Münşe 'àt, Ebū Bekr Rif'at (T; 13/4, 296) } \\
\text { 2. Dīvān, Ebū Bekr Rif'at (T; 13/2, 430) }\end{array}$ & Ms.or.oct. 2552 \\
\hline 733. & 25.06 .1927 & $\begin{array}{l}\text { 1. Şevk-engīz, Sünbülzāde Vehbī (T; 13/2, 558) } \\
\text { 2. Rakḳāṣ-nāme, Fāżı̀l-1 Enderūnī (T; 13/2, 504) }\end{array}$ & Ms.or.quart. 1755 \\
\hline 734. & 25.06 .1927 & $\begin{array}{c}\text { es-Siyāsetü'ş-şer 'iye fì ıșlāhil'r-rā' ‘̀ ve'r-ra ìye İbn Teymiye, } \\
\text { Aḥmed b. 'Abdülḥalīm (A; KOHD) }\end{array}$ & Ms.or.oct. 2553 \\
\hline 735 . & 25.06 .1927 & Şerhü Füṣūṣi'l-hikem, Dāvūd-1 Kayṣerī (A; KOHD) & Ms.or.oct. 3082 \\
\hline 736. & 25.06.1927 & 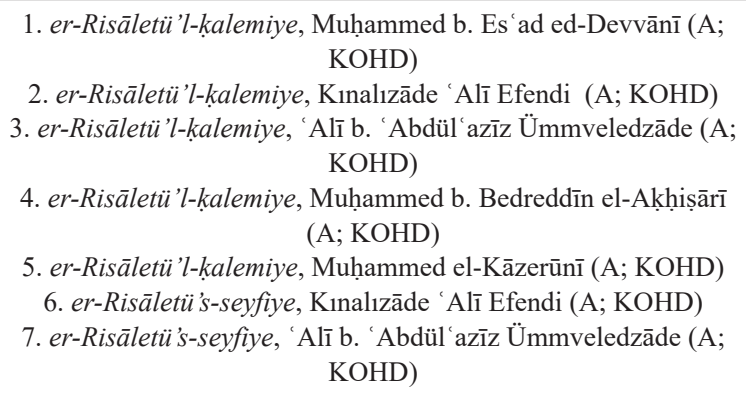 & Ms.or.oct. 2554 \\
\hline 737. & 25.06 .1927 & Dìvān-ı lügāziyāt-ı Reşìd, Reşīd (T; 13/3, 273) & Ms.or.oct. 3083 \\
\hline 738. & 25.06 .1927 & Risāle-i Hatțātīn (T; GDA) & Ms.or.oct. 2555 \\
\hline 739. & 25.06 .1927 & $\begin{array}{c}\text { Kānūnu's-sa 'ādet der-siyākat, 'Alā'eddīn Felekī-i Tebrīzī (F; } \\
14 / 1,183)\end{array}$ & Ms.or.oct. 2556 \\
\hline 740. & 25.06 .1927 & $\begin{array}{l}\text { Şerhü'(l-Muḳaddime)l-Ezheriye fì 'ilmi'l- 'Arabiye, Hāāid b. } \\
\text { 'Abdullāh el-Ezherī (A; KOHD) }\end{array}$ & Ms.or.oct. 3084 \\
\hline 741. & 25.06 .1927 & 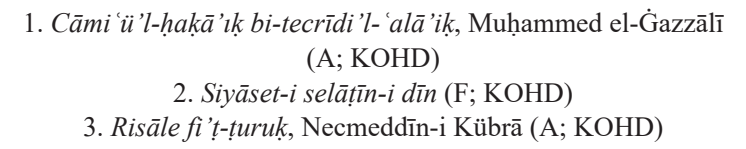 & Ms.or.oct. 2557 \\
\hline 742. & 25.06.1927 & Şerḥü Ebyāti'l-ādāb, Muḥsin b. Mușțafā (A; KOHD) & Ms.or.oct. 2558 \\
\hline
\end{tabular}


The Manuscripts Rescher Sold to the Berlin State Library (Reşer'in Berlin Devlet Kütüphanesi'ne Sattığı Yazmalar)

\begin{tabular}{|c|c|c|c|}
\hline Nr. & $\begin{array}{l}\text { Date } \\
\text { Tarih }\end{array}$ & $\begin{array}{c}\text { Name of Work, Name of Author (Language; Catalogue } \\
\text { Information) } \\
\text { Eser adı, Müellif adı (Dil; Katalog Bilgisi) }\end{array}$ & $\begin{array}{l}\text { Shelf nr. } \\
\text { Raf nr. }\end{array}$ \\
\hline 743. & 25.06.1927 & $\begin{array}{l}\text { 1. Şerhü Kaṣīdeti İbn Kậ̣̄b el-Bān, 'Uryānī 'Oșmān Efendi (A; } \\
\text { KOHD) } \\
\text { 2. Kașīde, 'Abdullāh b. Muḥammad b. Kaḍ̄īb el-Bān (A; KOHD) }\end{array}$ & Ms.or.oct. 2559 \\
\hline 744. & 25.06.1927 & Gülzār-l șavāb, Nefeszāde İbrāhīm (T; 13/4, 524) & Ms.or.oct. 2560 \\
\hline 745. & 25.06 .1927 & Mukārene beyne'l-Kur 'ān ve'ş-şi 'r (A-F; KOHD) & Ms.or.oct. 2561 \\
\hline 746. & 25.06.1927 & 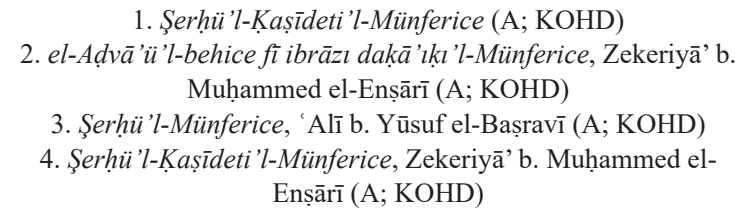 & Ms.or.oct. 2562 \\
\hline 747. & 25.06.1927 & 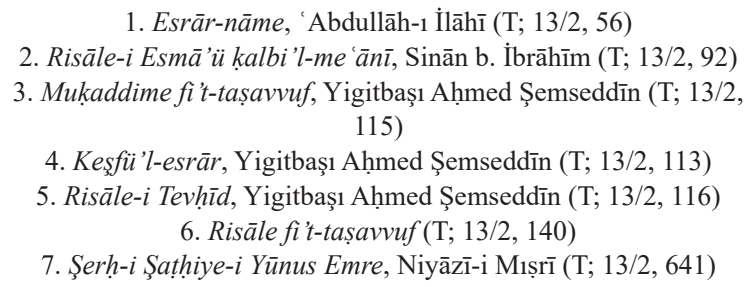 & Ms.or.oct. 2563 \\
\hline 748. & 25.06 .1927 & 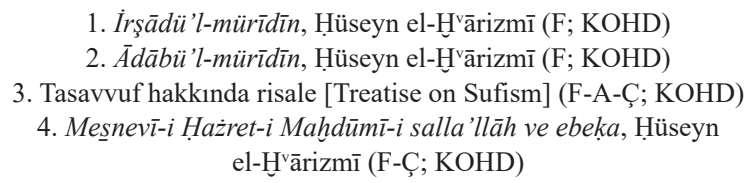 & Ms.or.oct. 2564 \\
\hline 749. & 25.06 .1927 & $\begin{array}{c}\text { Cāmi 'ü'l-fetāvā, Kurḳ Emre Meḥmed b. Muṣṭafā el-Hamīdī (A; } \\
\text { KOHD) }\end{array}$ & Ms.or.oct. 2565 \\
\hline 750. & 25.06.1927 & Şerhh-i Șad Kelime-i Bațlamyūs, Nașīreddīn-i Ṭūsī (F; 14/1, 232) & Ms.or.oct. 2566 \\
\hline 751. & 25.06 .1927 & Tārīh-i Rıḍānzzāde, 'Abdullāh b. Rıḍvān (T; 13/1, 110) & Ms.or.quart. 1756 \\
\hline 752. & 25.06.1927 & Muhtārātü'n-nevāzil, Burhāneddīn el-Merg̀īnānī (A; KOHD) & Ms.or.oct. 2567 \\
\hline 753. & 25.06 .1927 & Tuḥfetü'ș-ṣukūk, Nu'mān (T; 13/4, 69) & Ms.or.oct. 2568 \\
\hline 754. & 25.06 .1927 & Rūznāmçe (T; GDA) & Ms.or.oct. 2569 \\
\hline 755. & 13.08 .1927 & $\begin{array}{c}\text { el-Muhịṭü'l-Burhānī fi'l-fikhi'n-Nu'mānē, Burhāneddīn Mạ̣mūd } \\
\text { b. Aḥmed İbn Māze (A; KOHD) }\end{array}$ & Ms.or.quart. 1614 \\
\hline 756. & 13.08.1927 & Fetāvā-yı Ebu's-Su'ūd (T; 13/5, 103) & Ms.or.quart. 1615 \\
\hline 757. & 13.08.1927 & Terceme-i Şir 'atü'l-İslām, Aḥmed b. Seyyid el-Biġavī (T; 13/2, 1) & Ms.or.oct. 2571 \\
\hline 758. & 13.08.1927 & Dìvān, 'Arşī Dede (T; 13/2, 259) & Ms.or.oct. 2572 \\
\hline 759. & 13.08.1927 & $\begin{array}{l}\text { Binā-yı Ka 'beye dā'ir risāle, Baldırzāde Meḥmed Efendi (T; } \\
\qquad 13 / 4,331)\end{array}$ & Ms.or.oct. 2573 \\
\hline
\end{tabular}


The Manuscripts Rescher Sold to the Berlin State Library (Reşer'in Berlin Devlet Kütüphanesi'ne Sattığı Yazmalar)

\begin{tabular}{|c|c|c|c|}
\hline Nr. & $\begin{array}{l}\text { Date } \\
\text { Tarih }\end{array}$ & $\begin{array}{c}\text { Name of Work, Name of Author (Language; Catalogue } \\
\text { Information) } \\
\text { Eser adı, Müellif adı (Dil; Katalog Bilgisi) }\end{array}$ & $\begin{array}{l}\text { Shelf nr. } \\
\text { Raf nr. }\end{array}$ \\
\hline 760. & 13.08.1927 & 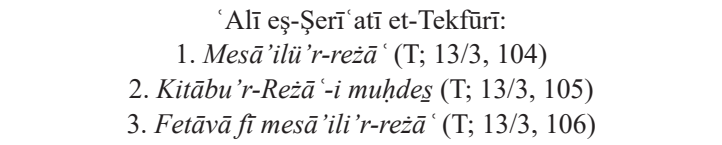 & Ms.or.oct. 3085 \\
\hline 761. & 13.08.1927 & Rāḥatü'l-ervāh mūnisü'l-eşbāḥ, Dervīş Cām (T; 13/2, 244) & Ms.or.oct. 2574 \\
\hline 762. & 29.09 .1927 & Tezkkiretü'ş-şu'arā, Ķınalızāde Ḥasan Çelebi (T; 13/4, 309) & Ms.or.oct. 2578 \\
\hline 763. & 29.09 .1927 & $\begin{array}{c}\text { Mir'ātü'l-menzilāt memerrātü'l-kevākibāt, Makāmī Süleymān } \\
(\mathrm{T} ; 13 / 4,357)\end{array}$ & Ms.or.oct. 2579 \\
\hline 764. & 29.09.1927 & 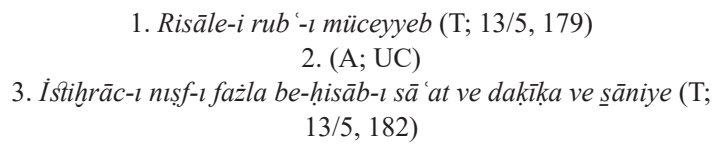 & Ms.or.quart. 1757 \\
\hline 765. & 29.09 .1927 & Şerḥ-i Rūznāme (T; GDA) & Ms.or.oct. 3086 \\
\hline 766. & 29.09 .1927 & 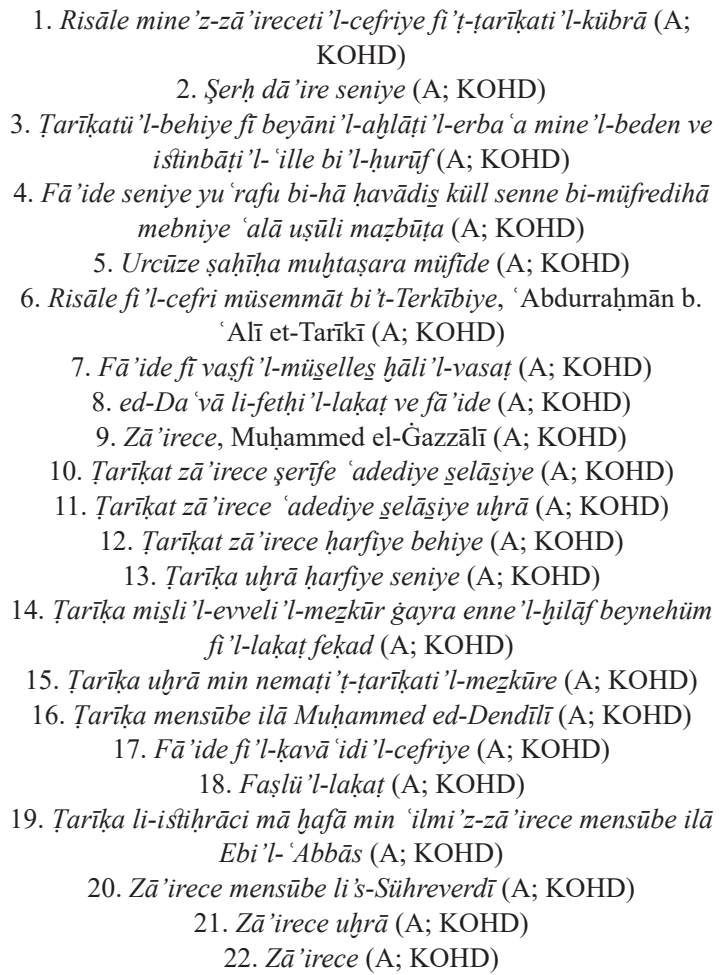 & Ms.or.quart. 1616 \\
\hline
\end{tabular}


The Manuscripts Rescher Sold to the Berlin State Library (Reşer'in Berlin Devlet Kütüphanesi'ne Sattığı Yazmalar)

\begin{tabular}{|c|c|c|c|}
\hline Nr. & $\begin{array}{l}\text { Date } \\
\text { Tarih }\end{array}$ & $\begin{array}{c}\text { Name of Work, Name of Author (Language; Catalogue } \\
\text { Information) } \\
\text { Eser adı, Müellif adı (Dil; Katalog Bilgisi) }\end{array}$ & $\begin{array}{l}\text { Shelf nr. } \\
\text { Raf nr. }\end{array}$ \\
\hline 766. & 29.09 .1927 & 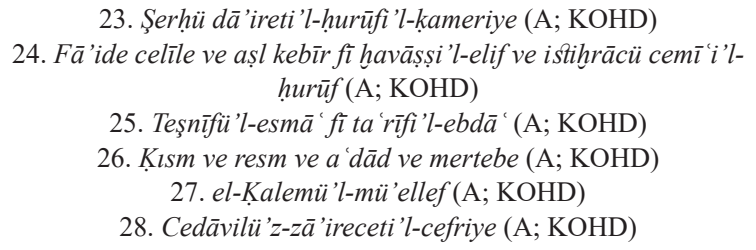 & Ms.or.quart. 1616 \\
\hline 767. & 29.09 .1927 & $\begin{array}{l}\text { Risāle fi'l-hnātemi'l-müselles, Muhammed b. 'Abdullāh Ḳorḳmas } \\
\text { (A; 17B/1, 144) }\end{array}$ & Ms.or.oct. 2580 \\
\hline 768. & 29.09 .1927 & 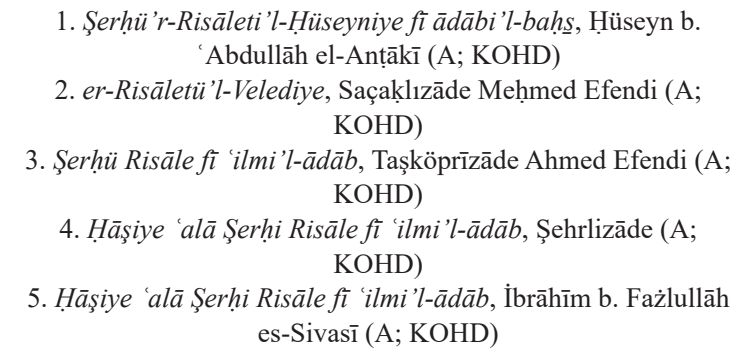 & Ms.or.oct. 2581 \\
\hline 769. & 29.09.1927 & Tezkiye-i Ehl-i Beyt (T; 13/4, 186) & Ms.or.oct. 2582 \\
\hline 770. & 29.09 .1927 & İstinzālü'l-ervāh ve istihdāmü'l-ḥurūf(A; UC) & Ms.or.oct. 3087 \\
\hline 771. & 29.09.1927 & $\begin{array}{l}\text { 1. Elvāhu'l-cevāhir, Eflāțūn (A; KOHD) } \\
\text { 2. Kitāb-ı Hāâfiye-i Ca ferī, Ca' fer eș-Șādıḳ (F; KOHD) }\end{array}$ & Ms.or.oct. 2583 \\
\hline 772. & 29.09 .1927 & $\begin{array}{c}\text { en-Netā'icü t-tecrībiye 'ani'l-mukaddimāti'l-felekiye, Aḥmed b. } \\
\text { Aḥmed eş-Şehābī el-Hanefī (A; KOHD) }\end{array}$ & Ms.or.oct. 2584 \\
\hline 773. & 29.09.1927 & 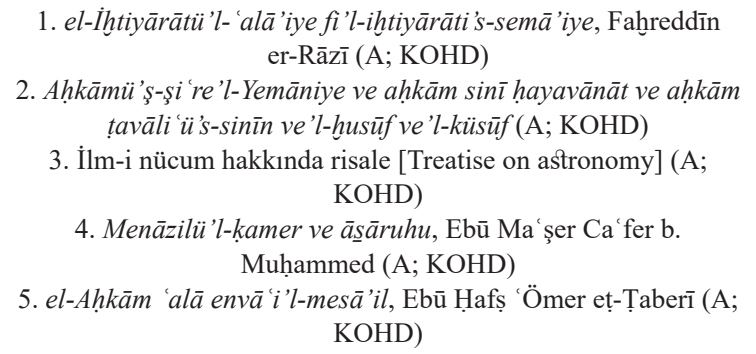 & Ms.or.quart. 1617 \\
\hline
\end{tabular}


The Manuscripts Rescher Sold to the Berlin State Library (Reşer'in Berlin Devlet Kütüphanesi'ne Sattığı Yazmalar)

\begin{tabular}{|c|c|c|c|}
\hline Nr. & $\begin{array}{l}\text { Date } \\
\text { Tarih }\end{array}$ & $\begin{array}{c}\text { Name of Work, Name of Author (Language; Catalogue } \\
\text { Information) } \\
\text { Eser adı, Müellif adı (Dil; Katalog Bilgisi) }\end{array}$ & $\begin{array}{l}\text { Shelf nr. } \\
\text { Raf nr. }\end{array}$ \\
\hline 774. & 29.09.1927 & 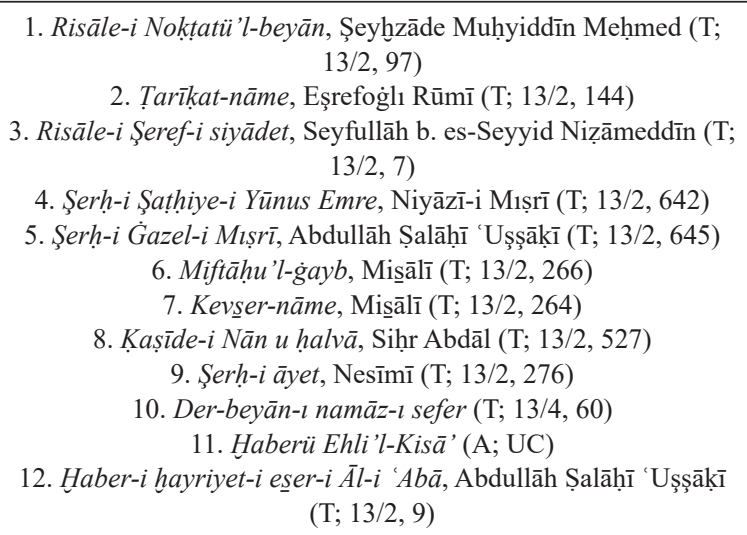 & Ms.or.oct. 2585 \\
\hline 775. & 29.09 .1927 & Dìvān, Misāāi $(\mathrm{T} ; 13 / 2,263)$ & Ms.or.oct. 2586 \\
\hline 776. & 29.09.1927 & $\begin{array}{l}\text { 1. el-Mukaddime fi 'ș-șalāt, Ebu'l-Leys es-Semerkandī (A; } \\
\text { KOHD) } \\
\text { 2. Kitāb Flkhhī (A; KOHD) }\end{array}$ & Ms.or.oct. 3088 \\
\hline 777. & 29.09 .1927 & Cāmi 'ü’l-icāreteyn, Şāṭrzāde Meḥmed 'Ārif (T; 13/4, 92) & Ms.or.oct. 2587 \\
\hline 778. & 29.09.1927 & 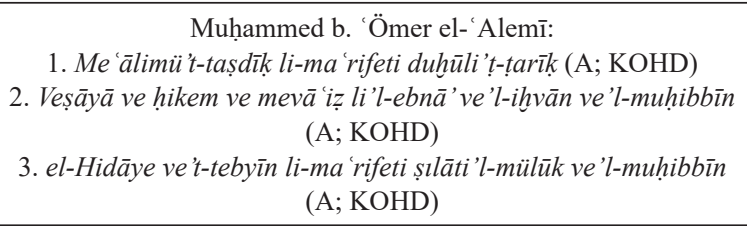 & Ms.or.oct. 2588 \\
\hline 779. & 29.09 .1927 & Mecmū 'a-i fetāvā, Fetḥullāh Efendi (T; 13/4, 85) & Ms.or.oct. 2589 \\
\hline 780. & 29.09.1927 & 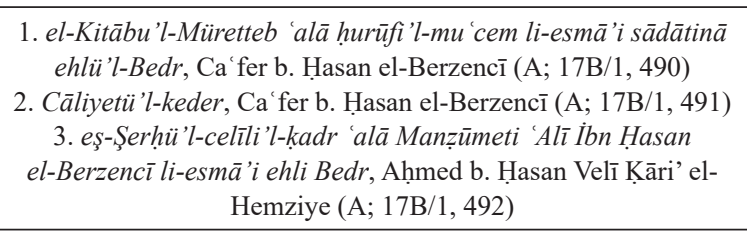 & Ms.or.oct. 2590 \\
\hline 781. & 29.09.1927 & 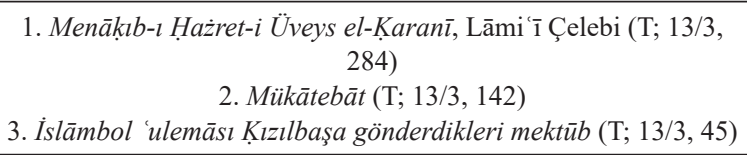 & Ms.or.oct. 3089 \\
\hline 782. & 29.09.1927 & 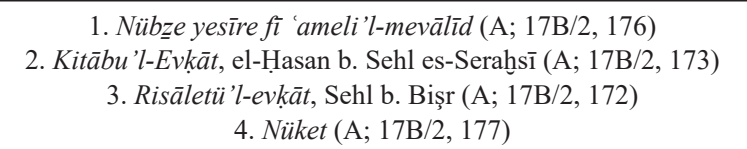 & Ms.or.oct. 2591 \\
\hline
\end{tabular}


The Manuscripts Rescher Sold to the Berlin State Library (Reşer'in Berlin Devlet Kütüphanesi'ne Sattığı Yazmalar)

\begin{tabular}{|c|c|c|c|}
\hline Nr. & $\begin{array}{l}\text { Date } \\
\text { Tarih }\end{array}$ & $\begin{array}{c}\text { Name of Work, Name of Author (Language; Catalogue } \\
\text { Information) } \\
\text { Eser adı, Müellif adı (Dil; Katalog Bilgisi) }\end{array}$ & $\begin{array}{c}\text { Shelf nr. } \\
\text { Raf nr. }\end{array}$ \\
\hline 783. & 29.09 .1927 & 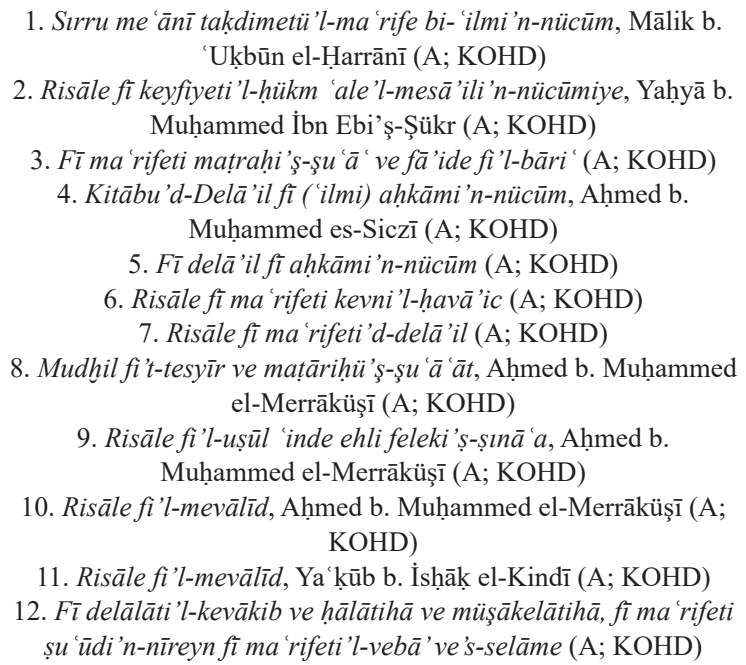 & Ms.or.oct. 2592 \\
\hline 784. & 29.09.1927 & Ahkāmü'l-mevālìd, Ebū Ma'şer (F; UC) & Ms.or.oct. 3090 \\
\hline 785. & 29.09.1927 & 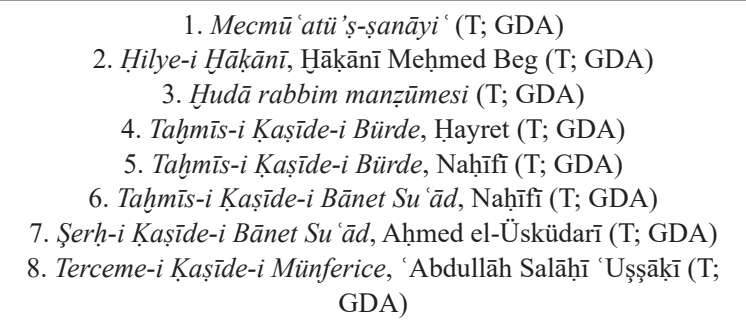 & Ms.or.oct. 3091 \\
\hline 786. & 29.09 .1927 & Kitāb-ı ḥikmet, Mesīḥā'̄ (F; 14/1, 123) & Ms.or.oct. 3092 \\
\hline 787. & 29.09 .1927 & $\begin{array}{l}\text { Karaçelebizāde 'Abdül'azīz Efendi: } \\
\text { 1. Ravżatü’l-ebrār }(\mathrm{T} ; 13 / 1,32) \\
\text { 2. Zeyl-i tārīh }(\mathrm{T} ; 13 / 1,34)\end{array}$ & Ms.or.quart. 1618 \\
\hline 788. & 19.10.1927 & el-Vesīletü'l-mahmmūdiye, Ḳāḍī Bedreddīn Maḥmūd (T; 13/2, 3) & Ms.or.quart. 1758 \\
\hline 789. & 19.10.1927 & Dīvān-ı Şems-i Tebrīz, Mevlānā Celāleddīn-i Rūmī (F; 14/1, 120) & Ms.or.oct. 2593 \\
\hline 790. & 19.10.1927 & Terceme-i Cezīretü'l- 'Arab (T; 13/5, 165) & Ms.or.quart. 1619 \\
\hline 791. & 26.11 .1927 & 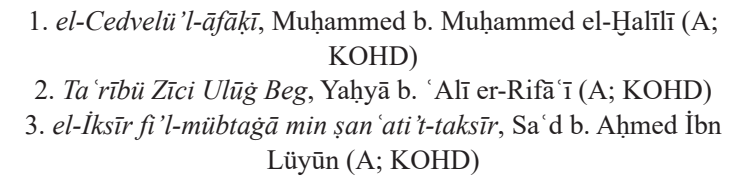 & Ms.or.oct. 3094 \\
\hline
\end{tabular}


The Manuscripts Rescher Sold to the Berlin State Library (Reşer'in Berlin Devlet Kütüphanesi'ne Sattığı Yazmalar)

\begin{tabular}{|c|c|c|c|}
\hline Nr. & $\begin{array}{l}\text { Date } \\
\text { Tarih }\end{array}$ & $\begin{array}{c}\text { Name of Work, Name of Author (Language; Catalogue } \\
\text { Information) } \\
\text { Eser adı, Müellif adı (Dil; Katalog Bilgisi) }\end{array}$ & $\begin{array}{l}\text { Shelf nr. } \\
\text { Raf nr. }\end{array}$ \\
\hline 792. & 26.11.1927 & 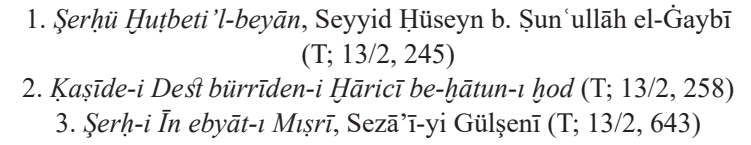 & Ms.or.oct. 2596 \\
\hline 793. & 26.11.1927 & Miṣbāḥu'l-hidāye, 'İmādeddīn 'Alī Faḳīh-i Kirmānī (F; 14/1, 18) & Ms.or.oct. 3095 \\
\hline 794. & 26.11.1927 & $\begin{array}{c}\text { Tuhfe-i Behīc-i Rașin̄ì terceme-i Zīc-i Kasīnī, Halīfezāde İsmā 'îl } \\
\text { Efendi (T; GDA) }\end{array}$ & Ms.or.oct. 2597 \\
\hline 795. & 26.11.1927 & $\begin{array}{l}\text { 1. Menākibu 'Abdülkāadir el-Cīlānì (A; KOHD) } \\
\text { 2. Haḳ̄katü'l-hakāà'ık fì şerhi keşfi'l-esrāri'd-dakā'ık (A; KOHD) }\end{array}$ & Ms.or.oct. 3096 \\
\hline 796. & 26.11 .1927 & Behcetü’l-menāzil, Meḥmed Edīb (T; 13/4, 336) & Ms.or.oct. 2653 \\
\hline 797. & 26.11 .1927 & Kı̀vāmu 't-tevārīh fì tercemeti Nizāmi 't-tevārīh $(\mathrm{T} ; 13 / 4,222)$ & Ms.or.oct. 2611 \\
\hline 798. & 08.12 .1927 & $\begin{array}{l}\text { Tuḥfetü vāhibi’l-mevāhib fì beyāni’l-makāamāt ve'l-merātib, } \\
\text { 'Abdüllațīf b. 'Abdurraḥmān el-Ḳudsī (A; KOHD) }\end{array}$ & Ms.or.oct. 2610 \\
\hline 799. & 08.12 .1927 & $\begin{array}{c}\text { Cevāhirü'l-ma 'ārif ve zevāhirü'l- 'avārıf, Fethullāh 'Ārif Çelebi } \\
\text { (T; 13/4, 458) }\end{array}$ & Ms.or.oct. 2609 \\
\hline 800. & 08.12 .1927 & Şerḥü 'Akīdetü 'ṭ-Ṭaḥāvī, 'Ömer b. İsḥāḳ el-Ġaznevī (A; KOHD) & Ms.or.oct. 2654 \\
\hline 801. & 08.12 .1927 & $\begin{array}{c}\text { Ị̇hārü'l-mahtūm 'ani's-sırri'l-mektūm, 'Abdurraḥmān b. Hüseyn } \\
\text { el-Ḥalebī (A; KOHD) }\end{array}$ & Ms.or.oct. 2612 \\
\hline 802. & 08.12 .1927 & Terceme-i Sevāḳıb, Dervīş Maḥmūd (T; 13/4, 141) & Ms.or.oct. 2613 \\
\hline 803. & 08.12 .1927 & $\begin{array}{c}\text { Niṣābü'l-ihtisāb fi'l-fetāvā, 'Ömer b. Muhammed es-Senāmī (A; } \\
\text { KOHD) }\end{array}$ & Ms.or.oct. 3097 \\
\hline 804. & 08.12 .1927 & 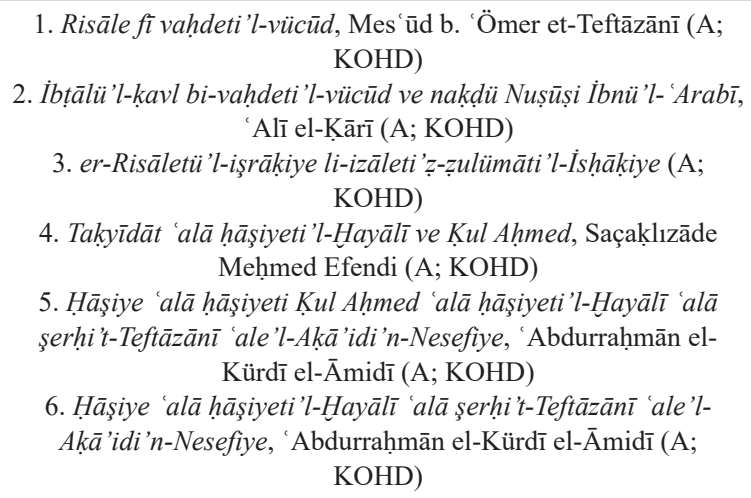 & Ms.or.oct. 3099 \\
\hline 805. & 23.12 .1927 & Tācü't-tevārīh, Hoca Sa 'deddīn (T; 13/4, 247) & Ms.or.oct. 2648 \\
\hline 806. & 23.12 .1927 & Şerh-i Mu'ammāa-yı esmāü'l-hüsnāa, 'Alī b. 'Oșmān (T; 13/2, 616) & Ms.or.oct. 2649 \\
\hline 807. & 23.12 .1927 & $\begin{array}{c}\text { ed-Dürretü'l-fāhire 'alā remzi'ş-şecere, Aḥmed b. Muhammed } \\
\text { el-Būnī (A; KOHD) }\end{array}$ & Ms.or.oct. 2650 \\
\hline
\end{tabular}


The Manuscripts Rescher Sold to the Berlin State Library (Reşer'in Berlin Devlet Kütüphanesi'ne Sattığı Yazmalar)

\begin{tabular}{|c|c|c|c|}
\hline Nr. & $\begin{array}{l}\text { Date } \\
\text { Tarih }\end{array}$ & $\begin{array}{c}\text { Name of Work, Name of Author (Language; Catalogue } \\
\text { Information) } \\
\text { Eser adı, Müellif adı (Dil; Katalog Bilgisi) }\end{array}$ & $\begin{array}{l}\text { Shelf nr. } \\
\text { Raf nr. }\end{array}$ \\
\hline 808. & 23.12.1927 & $\begin{array}{c}\text { ed-Dürretü'l-beyżā' fì beyānı ahkāmi'ş-şerī'ati'l-gararā', } \\
\text { Dürrīzāde Muștafā Efendi (A; KOHD) }\end{array}$ & Ms.or.quart. 1630 \\
\hline 809. & 23.12.1927 & $\begin{array}{c}\text { Fu'ādü t-tefsīr livā' } \ddot{u} \text { 'l-manșūr }, \text { Ḥüseyn b. Meḥmed Geyvevī (T; } \\
13 / 5,5)\end{array}$ & Ms.or.quart. 1766 \\
\hline 810. & 05.01 .1928 & Gülzār-ı ma nevī, İbrāhīm Tennūrī (T; 13/2, 107) & Ms.or.oct. 2655 \\
\hline 811. & 05.01 .1928 & Dīvānçe, Naẓîf (T; GDA) & Ms.or.oct. 2656 \\
\hline 812. & 27.01 .1928 & Ískender-nāme $(\mathrm{T} ; 13 / 2,233)$ & Ms.or.quart. 1634 \\
\hline 813. & 27.01.1928 & $\begin{array}{l}\text { et-Tedbìrātü'l-ilāhiye fì ıșlāḥi'l-memleketi'l-insāniye, İbnü'l- } \\
\text { 'Arabī (A; KOHD) }\end{array}$ & Ms.or.oct. 2661 \\
\hline 814. & 27.01.1928 & 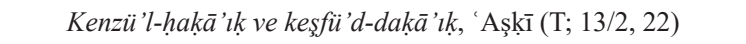 & Ms.or.oct. 2662 \\
\hline 815. & 27.01 .1928 & Aḥkāmü'l-mevālīd, Müneccimbaşı Meḥmed Çelebi $(\mathrm{T} ; 13 / 1,396)$ & Ms.or.oct. 3144 \\
\hline 816. & 06.02 .1928 & Mezmurlar ve ilahiler [Psalms and hymns] $(\mathrm{T} ; 4,35)$ & Ms.or.oct. 3145 \\
\hline 817. & 06.02 .1928 & el-Vecīz fì uṣūli'l-fiḳh, Yūsuf b. Hüseyn el-Kirmāst̄̄ (A; KOHD) & Ms.or.oct. 3146 \\
\hline 818. & 06.02 .1928 & $\begin{array}{l}\text { 1. et-Temhīd li-kavā'idi't-tevhīd, Maḥmūd b. Zeyd el-Lāmişī (A; } \\
\text { KOHD) } \\
\begin{array}{r}\text { 2. el-Bidāye mine 'l-Kifāye fi'l-hidāye fì ușūli'd-dīn, Nūreddīn } \\
\text { eṣ-Șābūnī (A; KOHD) }\end{array}\end{array}$ & Ms.or.oct. 3147 \\
\hline 819. & 06.02 .1928 & Levā'ihü'l-ḳamer, Ḥüseyn Vā'iz-i Kāşifī $(\mathrm{F} ; 14 / 1,7)$ & Ms.or.oct. 3148 \\
\hline 820. & 06.02 .1928 & $\begin{array}{c}\text { Kitāb 'alā każā'i’l-mevālìd hayyerahū ve ihtārehu ve tenakkāhu } \\
\text { min kütübi men kāne kablehu ve vaḍa 'ahu li-ibnihi Hermis, } \\
\text { Corciyus el-Mișrī (A; KOHD) }\end{array}$ & Ms.or.oct. 2663 \\
\hline 821. & 06.02 .1928 & $\begin{array}{c}\text { Ahkāmü’l-a 'vām, 'Alā'eddīn 'Alī Şāh b. Muhammed el-Hु'ārizmī } \\
\text { (F; KOHD) }\end{array}$ & Ms.or.oct. 2664 \\
\hline 822. & 06.02 .1928 & Hāżā Kitābu Samūr-ı Hindī (T; 13/4, 382) & Ms.or.oct. 2665 \\
\hline 823. & 06.02 .1928 & Melhame (T; 13/4, 383) & Ms.or.oct. 2666 \\
\hline 824. & 06.02 .1928 & $\begin{array}{l}\text { Risāle fì keyfiyeti istihrāci 't-takvīm, Maḥmūd b. Aḥmed el-Avfī } \\
\text { (A; KOHD) }\end{array}$ & Ms.or.oct. 3149 \\
\hline 825. & 10.03 .1928 & $\begin{array}{c}\text { Cevheretü'l-bidāye ve dürretü'n-nihāye, Șar1 'Abdullāh Efendi } \\
\text { ('Abdī) (T; 13/2, 105) }\end{array}$ & Ms.or.oct. 2667 \\
\hline 826. & 10.03 .1928 & 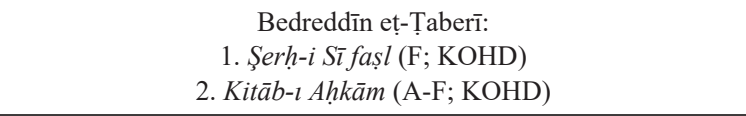 & Ms.or.oct. 2668 \\
\hline 827. & 10.03 .1928 & $\begin{array}{l}\text { 1. Dìvān, 'Abdurraḥmān 'Ubeydī (T; 13/2, 465) } \\
\text { 2. Dīvān, Cevrī İbrāhīm Çelebi (T; 13/2, 339) }\end{array}$ & Ms.or.oct. 2669 \\
\hline 828. & 02.06 .1928 & $\begin{array}{c}\text { Kitābu'l-Hāvi'l-Kudsī fi'l-fürū', Aḥmed b. Muhammed el- } \\
\text { Ġaznevī (A; KOHD) }\end{array}$ & Ms.or.quart. 1660 \\
\hline 829. & 02.06 .1928 & el-Hā̄vì fi 'l-fetāvi, Maḥmūd b. İbrāhīm el-Hașīīi (A; KOHD) & Ms.or.quart. 1661 \\
\hline
\end{tabular}




\section{The Manuscripts Rescher Sold to the Berlin State Library (Reșer'in Berlin Devlet} Kütüphanesi'ne Sattığı Yazmalar)

\begin{tabular}{|c|c|c|c|}
\hline Nr. & $\begin{array}{l}\text { Date } \\
\text { Tarih }\end{array}$ & $\begin{array}{c}\text { Name of Work, Name of Author (Language; Catalogue } \\
\text { Information) } \\
\text { Eser adı, Müellif adı (Dil; Katalog Bilgisi) }\end{array}$ & $\begin{array}{l}\text { Shelf nr. } \\
\text { Raf nr. }\end{array}$ \\
\hline 830. & 02.06 .1928 & $\begin{array}{l}\text { el-Käfífi'l-fikh, Muhammed b. Muhammed el-Mervezī (A; } \\
\text { KOHD) }\end{array}$ & Ms.or.quart. 1662 \\
\hline 831. & 02.06 .1928 & Tezzkiretü Seyyid Ya 'kūb, Ya 'ḳūb b. Seyyid 'Alī (A; KOHD) & Ms.or.quart. 1814 \\
\hline 832. & 02.06 .1928 & Kitāb-ı Fārig̀, Fārìg-i Gīlanī (F; 14/1, 148) & Ms.or.oct. 2704 \\
\hline 833. & 02.06 .1928 & Dìvān, Tācīzāde Ca fer Çelebi (T; 13/2, 336) & Ms.or.oct. 2705 \\
\hline 834. & 02.06 .1928 & $\begin{array}{l}\text { Harìdetü'l- 'acā'ib ve ferīdetü'l-garā'ib, Mahmūd (Hațīb er- } \\
\text { Rumī) (T; 13/1, 303) }\end{array}$ & Ms.or.oct. 3338 \\
\hline 835. & 02.06 .1928 & Lugiat, Ṭabīb Aḥmed (T; GDA) & Ms.or.oct. 2706 \\
\hline 836. & 02.06 .1928 & Tārīh, Șolaḳzāde Meḥmed Hemdemī (T; 13/1, 157) & Ms.or.quart. 1663 \\
\hline 837. & 02.06 .1928 & Dīvān-ı Şems-i Tebrīz, Mevlānā Celāleddīn-i Rūmī (F; 14/1, 354) & Ms.or.quart. 1664 \\
\hline 838. & 02.06 .1928 & Cerrāhn-nāme, 'Alī eț-Ṭabīb-i Bursevī (T; 13/4, 389) & Ms.or.oct. 2707 \\
\hline 839. & 02.06 .1928 & Mecmū 'a-i mūsik̄i (T; 13/5, 289) & Ms.or.oct. 3339 \\
\hline 840. & 13.07.1928 & Kitābu Nebżeti'l-esrār (T; 13/4, 8) & Ms.or.oct. 2828 \\
\hline 841. & 13.07.1928 & 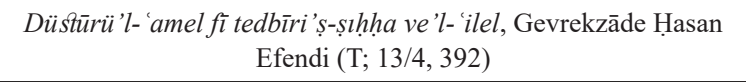 & Ms.or.oct. 2829 \\
\hline 842. & 13.07.1928 & Akrabādīn, Süleymān b. İbrāhīm (A; KOHD) & Ms.or.oct. 3250 \\
\hline 843. & 13.07.1928 & Mecma 'u'l-lețāyif, Sirāc b. 'Abdullāh (T; GDA) & Ms.or.quart. 1816 \\
\hline 844. & 13.07.1928 & $\begin{array}{c}\text { Şemsü'l-āfāk fì 'ilmi'l-hurūf ve'l-evfāk, 'Abdurrahmān b. } \\
\text { Muhamamed el-Bisțāmī (A; KOHD) }\end{array}$ & Ms.or.quart. 1673 \\
\hline 845. & 20.09 .1928 & Kitābu'l-Cāmi 'i’ş-şāhhì, Ebū Sa 'īd es-Siczī (A; 17B/2, 175) & Ms.or.quart. 1678 \\
\hline 846. & 20.09 .1928 & Süleymān-nāme-i kebīr, Firdevsī-i Rumī (T; 13/1, 52) & Ms.or.fol. 4154 \\
\hline 847. & 20.09 .1928 & Nūrü'l-vehhāc li-teshīli'l-īlāc, Mūsā Emānī $(\mathrm{T} ; 13 / 2,26)$ & Ms.or.oct. 2874 \\
\hline 848. & 20.09 .1928 & $\begin{array}{l}\text { Risāle-i Muhammediye fi'r-redd 'ani's-sādāti's-Sa 'diye, Şeyh } \\
\text { Sa'î̀ (T; 13/5, 96) }\end{array}$ & Ms.or.quart. 1679 \\
\hline 849. & 20.09 .1928 & Ṭarīkat-nāme, Eşrefog̀lı Rūmī $(\mathrm{T} ; 13 / 2,145)$ & Ms.or.oct. 2875 \\
\hline 850. & 20.09.1928 & Mükāleme-i Hāạș, İbrāhīm Ḩāṣṣ (T; 13/2, 166) & Ms.or.oct. 2876 \\
\hline 851. & 20.09 .1928 & $\begin{array}{l}\text { 1. Terceme-i Esrār-nāme-i Hemedānī (T; GDA) } \\
\text { 2. Terceme-i Mir'ātü'l-me 'ānī (T; GDA) } \\
\text { 3. Risāle-i Lübbü'l-lübb ve sırru's-sırr, Niyāzì-i Mișrī (T; GDA) }\end{array}$ & Ms.or.oct. 2877 \\
\hline 852. & 20.09 .1928 & Śimārü'l-esmār, 'Oșmānzāde Aḥmed Tā'ib (T; GDA) & Ms.or.oct. 2878 \\
\hline 853. & 20.09.1928 & Dìvān, Bülbülī (T; 13/5, 209) & Ms.or.oct. 3263 \\
\hline 854. & 20.09.1928 & Dürretü'l-așdāf $(\mathrm{T} ; 13 / 4,161)$ & Ms.or.oct. 2879 \\
\hline 855. & 20.09.1928 & $\begin{array}{c}\text { Maḳāmāt-ı } H^{\mathrm{v}} \bar{a} c e \text { 'Ubeydullāh Ahrārr, 'Ubeydullāh Ahrār (F; } \\
\text { KOHD) }\end{array}$ & Ms.or.oct. 2880 \\
\hline 856. & 20.09.1928 & $\bar{A}$ b-ı ḥayāt-ı Hiżrī, Hiżrīì Amasyavī (T; 13/5, 247) & Ms.or.oct. 3264 \\
\hline 857. & 20.09 .1928 & Kitābu Tertīli'l-ușūl ve tertībi'l-vüșūl (T; 13/4, 10) & Ms.or.oct. 2881 \\
\hline
\end{tabular}


The Manuscripts Rescher Sold to the Berlin State Library (Reşer'in Berlin Devlet Kütüphanesi'ne Sattığı Yazmalar)

\begin{tabular}{|c|c|c|c|}
\hline Nr. & $\begin{array}{l}\text { Date } \\
\text { Tarih }\end{array}$ & $\begin{array}{c}\text { Name of Work, Name of Author (Language; Catalogue } \\
\text { Information) } \\
\text { Eser adı, Müellif adı (Dil; Katalog Bilgisi) }\end{array}$ & $\begin{array}{l}\text { Shelf nr. } \\
\text { Raf nr. }\end{array}$ \\
\hline 858. & 20.09.1928 & Cevāhirnāme, Muḥammed b. Manșūr (F; 14/1, 133) & Ms.or.oct. 2882 \\
\hline 859. & 20.09.1928 & Mecmū a-i eş 'àr $(\mathrm{T} ; 13 / 5,237)$ & Ms.or.oct. 3265 \\
\hline 860. & 20.09.1928 & Kavā'id-i mu 'ammeyāt, Rumūzī Mușțafā Beg (T; 13/5, 239) & Ms.or.oct. 3350 \\
\hline 861. & 20.09 .1928 & $\begin{array}{l}\text { 1. Teshīlü'ț-țbb, Hācı Paşa (Celāleddīn Hıżr) }(\mathrm{T} ; 13 / 4,391) \\
\text { 2. Tıbbi tavsiyeler içeren metin [Text containing medical } \\
\text { recommendations] (T; 13/4, 411) } \\
\text { 3. İlaçlar hakkında manzume [Poem on medications] (T; 13/4, } \\
\text { 412) } \\
\text { 4. Tıbbi tavsiyeler içeren metin [Text containing medical } \\
\text { recommendations] }(\mathrm{T} ; 13 / 4,413)\end{array}$ & Ms.or.oct. 2883 \\
\hline 862. & 20.09.1928 & $\begin{array}{c}\text { Salāt-ı Mes '́u dì, Mes 'ūd b. Muhammed es-Semerḳandī (F; } \\
\text { KOHD) }\end{array}$ & Ms.or.quart. 1788 \\
\hline 863. & 18.12 .1928 & $\begin{array}{l}\text { Kitābu La 'bi'ş-şațranci'l-Hindī, Ebu'l-Ferec el-Muẓaffer eş- } \\
\text { Şațrancī }(\mathrm{A} ; 17 \mathrm{~B} / 2,153)\end{array}$ & Ms.or.oct. 2890 \\
\hline 864. & 18.12 .1928 & $\begin{array}{c}\text { Cāmi '̈̈'l-beyān 'an te 'vīli'l-Kur 'ān, Muhammed b. Cerīr eț- } \\
\text { Țaberī }(\mathrm{A} ; 17 \mathrm{~B} / 2,15)\end{array}$ & Ms.or.fol. 4155 \\
\hline 865. & 18.12 .1928 & $\begin{array}{l}\text { Te 'vīlātü'l-Ḳur'ān, Ebū Manșūr Muhammed el-Māturīdī (A; } \\
\text { 17B/2,16) }\end{array}$ & Ms.or.fol. 4156 \\
\hline 866. & 18.12 .1928 & $\begin{array}{l}\text { el-Lüma 'fi'l-havādis ve'l-bida', İdrīs b. Beydekīn et-Türkmānī } \\
\text { (A; KOHD) }\end{array}$ & Ms.or.quart. 1681 \\
\hline 867. & 18.12 .1928 & Terceme-i Muvatța', Mușțafā b. Meḥmed (T; 13/4, 67) & Ms.or.oct. 2891 \\
\hline 868. & 18.12 .1928 & Risāletü'l-firāset ve's-siyādet tercemesi, 'Ākif Paşa (T; 13/4, 166) & Ms.or.oct. 2892 \\
\hline 869. & 18.12 .1928 & 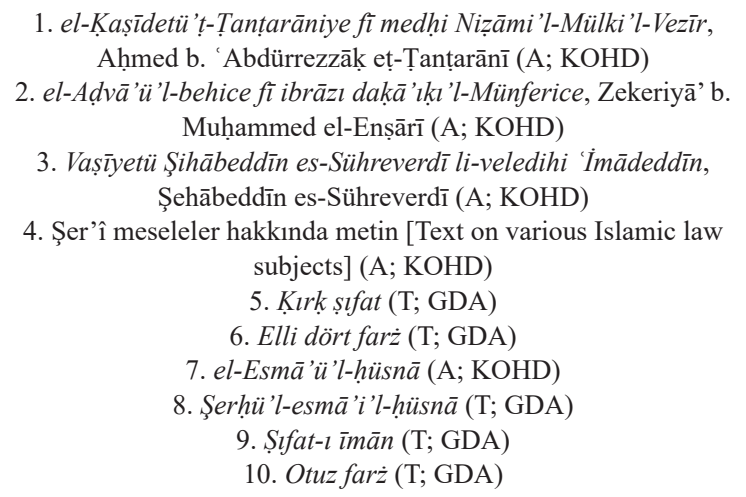 & Ms.or.oct. 2893 \\
\hline
\end{tabular}


The Manuscripts Rescher Sold to the Berlin State Library (Reşer'in Berlin Devlet Kütüphanesi'ne Sattığı Yazmalar)

\begin{tabular}{|c|c|c|c|}
\hline Nr. & $\begin{array}{l}\text { Date } \\
\text { Tarih }\end{array}$ & $\begin{array}{l}\text { Name of Work, Name of Author (Language; Catalogue } \\
\text { Information) } \\
\text { Eser adı, Müellif adı (Dil; Katalog Bilgisi) }\end{array}$ & $\begin{array}{l}\text { Shelf nr. } \\
\text { Raf nr. }\end{array}$ \\
\hline 869. & 18.12 .1928 & 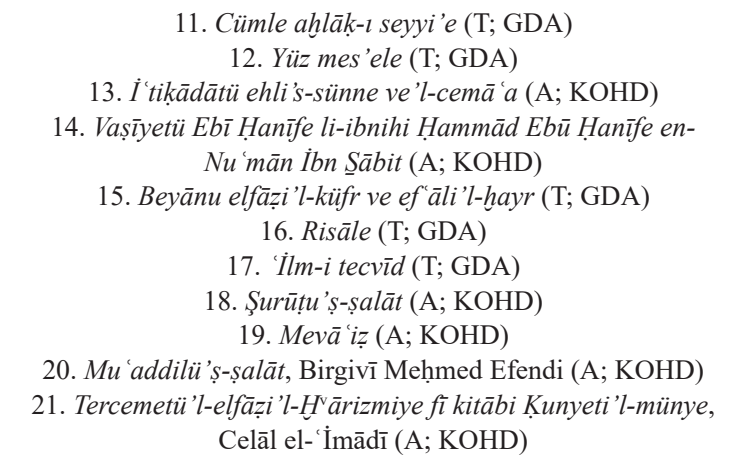 & Ms.or.oct. 2893 \\
\hline 870. & 18.12 .1928 & $\begin{array}{c}\text { Zehretü'r-riyāż ve nüzhetü'l-kulūbi'l-mirāḍ, Süleymān b. Dāvūd } \\
\text { es-Saḳsīn̄̄ (A; KOHD) }\end{array}$ & Ms.or.quart. 1682 \\
\hline 871. & 18.12 .1928 & Müzekki'n-nüfüs, Eşrefog̀lı Rūmī (T; 13/2,28) & Ms.or.oct. 2894 \\
\hline 872. & 18.12.1928 & Tārīh, Süleymān 'İzzī (T; 13/1, 186A-B), 2 c. [vols.] & Ms.or.fol. 4157 \\
\hline 873. & 21.02 .1929 & 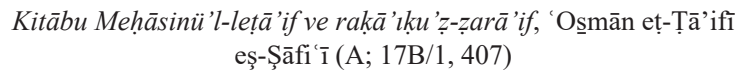 & Ms.or.oct. 3355 \\
\hline 874. & 21.02.1929 & Mirḳātü'l-cihād, Mușțafā 'Ālī (T; 13/1, 100) & Ms.or.oct. 3356 \\
\hline 875. & 21.02.1929 & $\begin{array}{l}\text { 1. Feżā'ilü'ş-Şām }(\mathrm{T} ; 13 / 4,345) \\
\text { 2. Menāḳı-ı Maḥmūd Paşa-yı velì }(\mathrm{T} ; 13 / 4,264) \\
\text { 3. Hāzā kitābu Tevārīh-i Anțākiye }(\mathrm{T} ; 13 / 4,346)\end{array}$ & Ms.or.oct. 2896 \\
\hline 876. & 21.02.1929 & Hulāṣatü'l-fetāvā, Țāhir b. Aḥmed el-Buhārī (A; KOHD) & Ms.or.fol. 4159 \\
\hline 877. & 21.02 .1929 & Bahrü'l-vilāye, Süleymān Şeyhī (T; 13/5, 158) & Ms.or.quart. 1683 \\
\hline 878. & 21.02 .1929 & Zübdetü't-tevārīhn, Mușțafā 'Ālī (T; 13/4, 196) & Ms.or.oct. 2897 \\
\hline 879. & 21.02 .1929 & Esrār-nāme, Ferīdeddīn-i 'Atțār (F; KOHD) & Ms.or.oct. 2899 \\
\hline 880. & 21.02.1929 & Kılyāmet-nāme, Ebu'l-Ḥasan 'Alī el-A 'lā (F; 14/1, 72) & Ms.or.oct. 2900 \\
\hline 881. & 21.02.1929 & $\begin{array}{c}\text { Enīsü'ț-tālibīn ve 'uddetü's-sālikīn, Șalāḥ b. Mübārek el-Buhārī } \\
(\mathrm{F} ; 14 / 1,369)\end{array}$ & Ms.or.oct. 2901 \\
\hline 882. & 09.04 .1929 & Duhrü'l- 'ābidīn, Meḥmed b. 'Abdüllațīf İbn Melek (A; KOHD) & Ms.or.oct. 3357 \\
\hline 883. & 09.04 .1929 & Tevārīh-i Āl-i 'Oșmān $(\mathrm{T} ; 13 / 1,141)$ & Ms.or.fol. 4160 \\
\hline 884. & 09.04 .1929 & 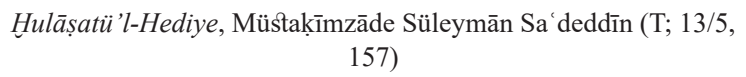 & Ms.or.fol. 4161 \\
\hline 885. & 09.04 .1929 & Dīvān-ı Maẓhar, Habībullāh Cān Cānān Maẓhar (F; KOHD) & Ms.or.oct. 2902 \\
\hline 886. & 09.04 .1929 & $\begin{array}{l}\text { Nābī: } \\
\text { 1. Tuhfetü'l-Haremeyn }(\mathrm{T} ; 13 / 4,339) \\
\text { 2. Hayriye }(\mathrm{T} ; 13 / 2,195)\end{array}$ & Ms.or.oct. 2903 \\
\hline 887. & 09.04 .1929 & $\begin{array}{c}\text { Terceme-i 'Avārıfü'l-ma 'ārif, Aḥmed b. Seyyid el-Big̉avī (T; } \\
13 / 2,19)\end{array}$ & Ms.or.oct. 2904 \\
\hline
\end{tabular}


The Manuscripts Rescher Sold to the Berlin State Library (Reşer'in Berlin Devlet Kütüphanesi'ne Sattığı Yazmalar)

\begin{tabular}{|c|c|c|c|}
\hline Nr. & $\begin{array}{l}\text { Date } \\
\text { Tarih }\end{array}$ & $\begin{array}{c}\text { Name of Work, Name of Author (Language; Catalogue } \\
\text { Information) } \\
\text { Eser adı, Müellif adı (Dil; Katalog Bilgisi) }\end{array}$ & $\begin{array}{l}\text { Shelf nr. } \\
\text { Raf nr. }\end{array}$ \\
\hline 888. & 09.04.1929 & Mevāhibü'l-hallāk fì merātibi'l-ahlāk (T; 13/3, 118) & Ms.or.fol. 4162 \\
\hline 889. & 09.04.1929 & Tārīh-i Taberī $(\mathrm{T} ; 13 / 1,9)$ & Ms.or.fol. 4163 \\
\hline 890. & 09.04 .1929 & $\begin{array}{c}\text { Kitābu Es 'ileti cāmi 'i esrārı müşkilātì'l-Kur'āni’l- 'az̄ìm, } \\
\text { Muhammed b. Ebī Bekr er-Rāzī (A; KOHD) }\end{array}$ & Ms.or.oct. 2905 \\
\hline 891. & 10.04.1929 & Șaḥîfe-i şāhī, Hüüeyn Vā iẓ-i Kāşifî (F; KOHD) & Ms.or.fol. 4164 \\
\hline 892. & 10.04.1929 & $\begin{array}{c}\text { Kitābu Mir' 'āti'l- 'ukūul fì şerḥi ahbbāri Āli'r-Resūl, Muḥammed } \\
\text { Bāḳır b. Muḥammed Taḳi el-Meclisī (A; KOHD) }\end{array}$ & Ms.or.oct. 3358 \\
\hline 893. & 10.04.1929 & $\begin{array}{c}\dot{G} \bar{a} y e t u ̈ ' l-\bar{a} m a \bar{a} l \text {, Muhammed Ḥasan b. 'Abdullāh el-Māmeḳānī } \\
\text { (A; KOHD) }\end{array}$ & Ms.or.oct. 2906 \\
\hline 894. & 10.04.1929 & 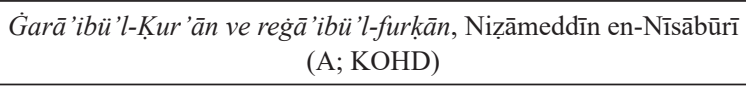 & Ms.or.quart. 1685 \\
\hline 895. & 10.04.1929 & $\begin{array}{c}\text { Kitābu Mecma 'i’l-beyān li- 'ulūmi’l-Kur'ān, el-Fażl b. el-Ḥasan } \\
\text { eț-Ṭabersī (A; KOHD) }\end{array}$ & Ms.or.fol. 4165 \\
\hline 896. & 10.04 .1929 & $\begin{array}{l}\text { Hulāṣatü'l-ahbāar, Muḥammed Mehdī b. Muhammed Ca' fer et- } \\
\text { Tinkābunī (F; KOHD) }\end{array}$ & Ms.or.fol. 4166 \\
\hline 897. & 10.04 .1929 & $\begin{array}{c}\text { Envāru'r-rebī fì envā'i’l-bed̄̄', 'Alī b. Aḥmed b. Ma șūm (A; } \\
\text { KOHD) }\end{array}$ & Ms.or.fol. 4167 \\
\hline 898. & 10.04.1929 & Rūznāmçeler, Mīrzāzāde Meḥmed Sa ‘̄d (T; 13/1, 233) & Ms.or.fol. 4168 \\
\hline 899. & 10.04.1929 & $\begin{array}{c}\text { Kitābu't-Tecrīd, 'Abdurraḥmān b. Muḥammed el-Kirmānī (A; } \\
\text { KOHD) }\end{array}$ & Ms.or.oct. 3359 \\
\hline 900. & 10.04.1929 & Tezkire fi 'ilmi'l-bezyere $(\mathrm{F} ; 14 / 1,121)$ & Ms.or.oct. 2907 \\
\hline 901. & 10.04.1929 & Vakfiye, Feyżullāh Efendi $(\mathrm{T} ; 13 / 1,241)$ & Ms.or.quart. 1827 \\
\hline 902. & 10.04.1929 & Sefāret-nāme, İbrāhīm Ḥanīf (T; 13/4, 198) & Ms.or.oct. 2908 \\
\hline 903. & 10.04.1929 & 'Acā'ibü'l-mahlūḳāt, Mușliḥeddīn Mușțafā Surūrī (T; 13/1, 301) & Ms.or.quart. 1828 \\
\hline 904. & 01.05 .1929 & Tercemetü'ḍ-Ḍaīr, Ḍarīr (T; 13/1, 60A-C) 3 c. & Ms.or.fol. 4169 \\
\hline 905. & 01.05 .1929 & 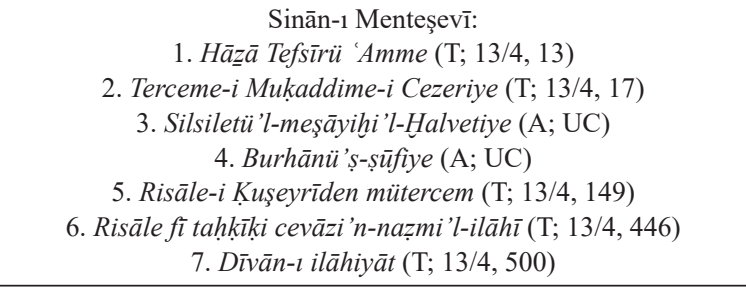 & Ms.or.oct. 2912 \\
\hline 906. & 01.05 .1929 & $\begin{array}{l}\text { 1. Şerh-i Risāle-i Kuşçi der hey'et, Muṣliḥeddīn el-Lārī (F; } \\
\text { KOHD) } \\
\text { 2. Şerhü'd-dā'ireti'l-Hindiye, Hüseyn el-Hüseynī el-Hुalhālī (A; } \\
\text { KOHD) }\end{array}$ & Ms.or.oct. 2913 \\
\hline 907. & 06.06 .1929 & $\begin{array}{c}\text { Taṭbīkāt-ı kavā'id-i fikhiye-i hayriye, Meḥmed Hayreddīn-i } \\
\text { Filibevī (T; 13/4, 65) }\end{array}$ & Ms.or.oct. 2915 \\
\hline
\end{tabular}


The Manuscripts Rescher Sold to the Berlin State Library (Reşer'in Berlin Devlet Kütüphanesi'ne Sattığı Yazmalar)

\begin{tabular}{|c|c|c|c|}
\hline Nr. & $\begin{array}{l}\text { Date } \\
\text { Tarih }\end{array}$ & $\begin{array}{c}\text { Name of Work, Name of Author (Language; Catalogue } \\
\text { Information) } \\
\text { Eser adı, Müellif adı (Dil; Katalog Bilgisi) }\end{array}$ & $\begin{array}{l}\text { Shelf nr. } \\
\text { Raf nr. }\end{array}$ \\
\hline 908. & 27.11.1929 & Dìvān-ı Ṭusī Hurāsānī, Mullā Naẓīrī (F; KOHD) & Ms.or.oct. 2922 \\
\hline 909. & 27.11.1929 & Ka be-nāme, 'Abdurraḥmān b. 'Abdullāh Ġubārī (T; 13/4, 337) & Ms.or.oct. 2923 \\
\hline 910. & 27.11.1929 & $\begin{array}{c}\text { Kitābu'l-Vesā'ili'l-Kur'āniye ve'l-ed 'iyeti'n-nebeviye, Yahyā b. } \\
\text { el-Mehdī ez-Zeydī el-Hüseynī (A; KOHD) }\end{array}$ & Ms.or.quart. 1834 \\
\hline 911. & 19.02 .1930 & Kāşifü'l-esrār ve mūnisü'l-ebrār (T; 13/2, 647) & Ms.or.oct. 2925 \\
\hline 912. & 19.02.1930 & Mevāhib-i 'aliye, Ḥüseyn Vā'iz-i Kāşifī (F; Kraemer, 26) & Ms.or.fol. 4172 \\
\hline 913. & 19.02 .1930 & Dìvān, Mevlānā Bisāțī-i Semerḳandī (F; 14/1, 50) & Ms.or.oct. 2926 \\
\hline 914. & 19.02 .1930 & '̇şrret-nāme, Revānī (T; 13/2, 576) & Ms.or.oct. 3366 \\
\hline 915. & 19.02 .1930 & Furșat-nāme, Mușțafā 'Ālì (T; 13/4, 227) & Ms.or.oct. 2927 \\
\hline 916. & 19.02.1930 & K’șașu'l-enbiyā' $(\mathrm{T} ; 13 / 1,55)$ & Ms.or.quart. 1690 \\
\hline 917. & 19.02.1930 & Zeyl-i Tārīhl-i seyyāh $(\mathrm{T} ; 13 / 1,105)$ & Ms.or.fol. 4173 \\
\hline 918. & 19.02.1930 & 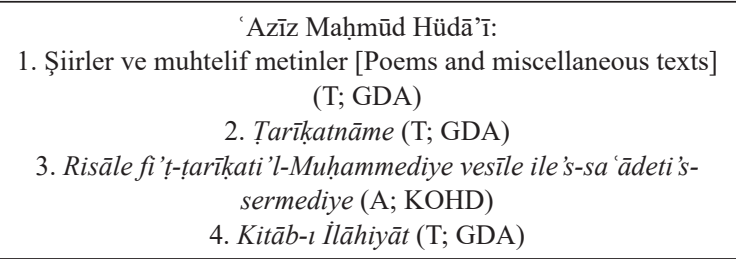 & Ms.or.oct. 3367 \\
\hline 919. & 19.02 .1930 & Muhtaṣar-ı Menāḳıb-nāme, 'Ömer Fu'ādī (T; 13/4, 131) & Ms.or.oct. 2928 \\
\hline 920. & 19.02 .1930 & 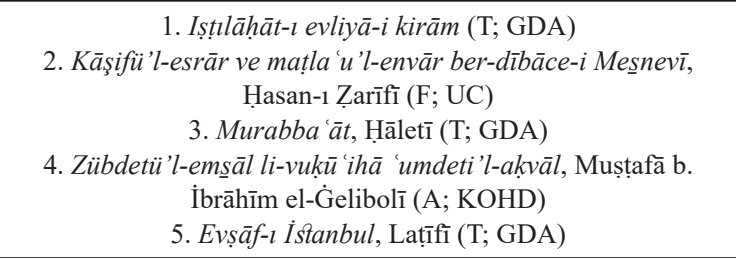 & Ms.or.oct. 2929 \\
\hline 921. & 19.02 .1930 & Gülzār-l ma nevī, İbrāhīm Tennūrī (T; 13/2, 106) & Ms.or.quart. 1691 \\
\hline 922. & 19.02 .1930 & Muhtașar-ı Feżā'il, Dervīș Mușṭafā (T; 13/5, 44) & Ms.or.quart. 1692 \\
\hline 923. & 19.02 .1930 & $\begin{array}{c}\text { Makāṣ̂sı-ı envār-l ġaybiye ve mașā'id-i ervāh-l țayyibe ve } \\
\text { ayniye, 'Abdullāh-1 Bosnevī }(\mathrm{T} ; 13 / 5,56)\end{array}$ & Ms.or.oct. 3270 \\
\hline 924. & 19.02 .1930 & $\begin{array}{l}\text { 1. Dìvānn, Nihānī Fāżı̀l b. 'Abdullāh (T; 13/2, 412) } \\
\text { 2. Kitāb-ı Esrār-nāme-i Hoca 'Atțāar, Aḥmedī (T; 13/2, 487) }\end{array}$ & Ms.or.oct. 2930 \\
\hline 925. & 19.02 .1930 & Küllìyat-i $H^{v} \bar{a} c \bar{u}, \mathrm{H}^{v} \mathrm{a} c \bar{u}-\mathrm{y} 1$ Kirmānī (F; KOHD) & Ms.or.oct. 3368 \\
\hline 926. & 19.02 .1930 & $\begin{array}{l}\text { 1. Münşe 'āt-l Ganīzāde (T; GDA) } \\
\text { 2. er-Risāletü'l-kalemiye, Ganīzāde Meḥmed Nādirī (A; KOHD) } \\
\text { 3. Șūret-i 'Ateknāme (T; GDA) } \\
\text { 4. Hz. Yusuf hakkında metin [Text on Prophet Joseph] (T; GDA) }\end{array}$ & Ms.or.oct. 2931 \\
\hline
\end{tabular}


The Manuscripts Rescher Sold to the Berlin State Library (Reşer'in Berlin Devlet Kütüphanesi'ne Sattığı Yazmalar)

\begin{tabular}{|c|c|c|c|}
\hline Nr. & $\begin{array}{l}\text { Date } \\
\text { Tarih }\end{array}$ & $\begin{array}{c}\text { Name of Work, Name of Author (Language; Catalogue } \\
\text { Information) } \\
\text { Eser adı, Müellif adı (Dil; Katalog Bilgisi) }\end{array}$ & $\begin{array}{l}\text { Shelf nr. } \\
\text { Raf nr. }\end{array}$ \\
\hline 927. & 19.02 .1930 & 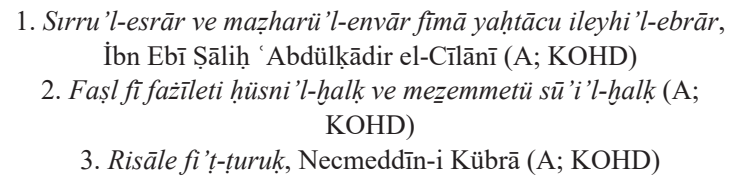 & Ms.or.oct. 2932 \\
\hline 928. & 19.02 .1930 & $\begin{array}{l}\text { Risāle der ahkām-ı țāli 'i mesā'il ve żamā'ir ve habāāā, Mīrim } \\
\text { Çelebī }(\mathrm{F} ; 14 / 1,378)\end{array}$ & Ms.or.oct. 2933 \\
\hline 929. & 19.02 .1930 & Vāḳı 'āt-ı Mīr Veys ve Şāh Hüseyn (T; GDA) & Ms.or.oct. 2934 \\
\hline 930. & 19.02 .1930 & $\begin{array}{l}\text { Cüz'fìhi cümle min merviyātı Ebì Yahyā Zekeriyā' el-Enșārī eş- } \\
\text { Şāafi ‘̄, Zekeriyā' b. Muhammed el-Enșārī (A; KOHD) }\end{array}$ & Ms.or.oct. 2935 \\
\hline 931. & 19.02 .1930 & Feżā'ilü'l- 'aşereti'l-kirāmi'l-berere (A; KOHD) & Ms.or.quart. 1693 \\
\hline 932. & 19.02 .1930 & 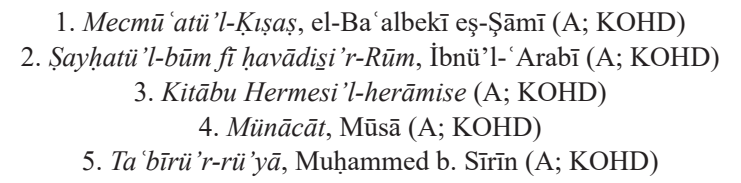 & Ms.or.quart. 1694 \\
\hline 933. & 19.02 .1930 & Dīvān, Nāṣireddīn ez-Zāāhirī el-Buhārī (F; 14/1, 256) & Ms.or.oct. 2936 \\
\hline 934. & 19.02 .1930 & Ravżatü'l-evliyā', Baldırzāde Meḥmed Efendi (T; 13/4, 128) & Ms.or.oct. 2937 \\
\hline 935. & 23.05 .1930 & Dìvān, Hasan-1 Dihlevī $(\mathrm{F} ; 14 / 1,46)$ & Ms.or.oct. 2964 \\
\hline 936. & 23.05 .1930 & Kitābu't-Taḥbīr fì 'ilmi t-težkīr, Ku uşeyrī (A; UC) & Ms.or.quart. 1703 \\
\hline 937. & 23.05 .1930 & Mașābịhü'l-ḳulūb, Ḥasan eş-Şī'ì es-Sebzevārī (F; 14/1, 321) & Ms.or.quart. 1704 \\
\hline 938. & 23.05 .1930 & $\begin{array}{c}\text { Naşkü̈l-ezhār fì 'acā'ibi'l-aḳtāar, Muḥammed b. Aḥmed İbn Iyās } \\
(\mathrm{A} ; 17 \mathrm{~A} / 1,51)\end{array}$ & Ms.or.oct. 2966 \\
\hline 939. & 23.05 .1930 & Kִıșaṣu'l-enbiyā', Muḥammed b. 'Abdullāh el-Kisā'̄i (A; KOHD) & Ms.or.oct. 2967 \\
\hline 940. & 23.05 .1930 & $\begin{array}{c}\text { Kitābu Hilyeti’l-ebrāar ve şi 'āri’l-ahyār, Yahyā b. Şeref en- } \\
\text { Nevevī (A; KOHD) }\end{array}$ & Ms.or.quart. 1705 \\
\hline 941. & 23.05 .1930 & Dìvān-l Şeyh Cüneyd, Cüneyd b. Maḥmūd-1 Şīrāzī (F; KOHD) & Ms.or.oct. 3374 \\
\hline 942. & 23.05 .1930 & Dìvān, Kemāl-i Hucendī (F; 14/1, 52) & Ms.or.oct. 2968 \\
\hline 943. & 23.05 .1930 & Mir'ātü'l-kā 'ināt, Hüsāmeddīn-i Bursevī (T; 13/1, 311) & Ms.or.quart. 1837 \\
\hline 944. & 23.05 .1930 & Mir'ātü'z-zamān fi tārīhni 'l-a yān, Sıbṭ İbnü'l-Cevzī (A; KOHD) & Ms.or.quart. 1838 \\
\hline 945. & 23.05 .1930 & $\begin{array}{c}\text { Kitābu'l- 'ilel 'alā serā'iri halīka ve șan 'ati'ț-țabì'a, Belinus el- } \\
\text { Hakīm (A; KOHD) }\end{array}$ & Ms.or.oct. 2969 \\
\hline 946. & 23.05 .1930 & Mecmū 'atü resā'il, İbnü'l-Heysem (A; KOHD) & Ms.or.oct. 2970 \\
\hline 947. & 23.05 .1930 & 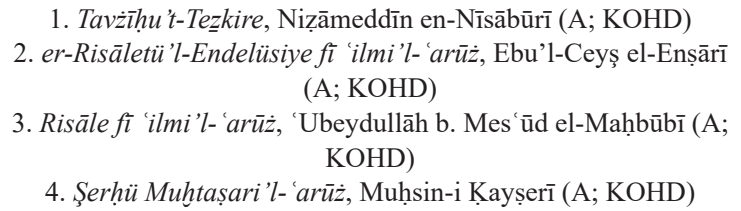 & Ms.or.fol. 4182 \\
\hline
\end{tabular}


The Manuscripts Rescher Sold to the Berlin State Library (Reşer'in Berlin Devlet Kütüphanesi'ne Sattığı Yazmalar)

\begin{tabular}{|c|c|c|c|}
\hline Nr. & $\begin{array}{l}\text { Date } \\
\text { Tarih }\end{array}$ & $\begin{array}{c}\text { Name of Work, Name of Author (Language; Catalogue } \\
\text { Information) } \\
\text { Eser adı, Müellif adı (Dil; Katalog Bilgisi) }\end{array}$ & $\begin{array}{l}\text { Shelf nr. } \\
\text { Raf nr. }\end{array}$ \\
\hline 948. & 24.09 .1930 & ed-Dīvān, Şemseddīn Ebu'l-Mekārim el-Bekrī $(\mathrm{A} ; 17 \mathrm{~B} / 1,382)$ & Ms.or.oct. 3295 \\
\hline 949. & 24.09 .1930 & $\begin{array}{c}\text { el-Maḳsadu't-tāmm bi-ma 'rifeti ahkāmi'l-ḥammām, Halīl b. Velī } \\
\text { b. Ca'fer }(\mathrm{A} ; 17 \mathrm{~B} / 2,216)\end{array}$ & Ms.or.oct. 2988 \\
\hline 950. & 24.09.1930 & Ferah-nāme, Hațībog̀lı $(\mathrm{T} ; 13 / 4,25)$ & Ms.or.oct. 2989 \\
\hline 951. & 24.09 .1930 & $\begin{array}{c}\text { İşādü'l-mürīd ile 'l-murād fi terceme-i Mirșādi'l- 'ibād, Kāāsım b. } \\
\text { Maḥmūd el-Ḳarahișārī }(\mathrm{T} ; 13 / 5,50)\end{array}$ & Ms.or.quart. 1719 \\
\hline 952. & 24.09 .1930 & 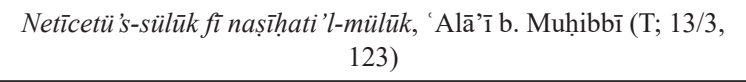 & Ms.or.quart. 1720 \\
\hline 953. & 24.09 .1930 & Şifä 'ü'l-mü'min, 'Alī Halīfe (T; 13/5, 8) & Ms.or.quart. 1721 \\
\hline 954. & 24.09 .1930 & $\begin{array}{l}\text { Enīsü'l-vahde ve celīsü'l-ḩalve, Maḥmūd b. Maḥmūd el-Ḥüseynī } \\
\qquad(\mathrm{F} ; 14 / 1,69)\end{array}$ & Ms.or.oct. 2990 \\
\hline 955. & 24.09 .1930 & 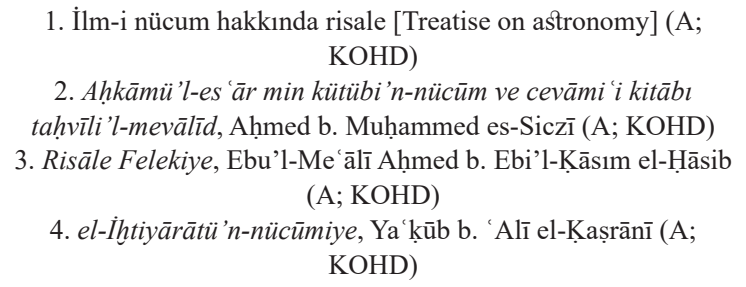 & Ms.or.oct. 3296 \\
\hline 956. & 24.09 .1930 & $\begin{array}{l}\text { Kitābu'l-Muharrer, 'Abdülkerīm b. Muhammed er-Rāfi '̄i (A; } \\
\text { KOHD) }\end{array}$ & Ms.or.quart. 1722 \\
\hline 957. & 24.09 .1930 & $\begin{array}{c}\text { Telhịṣü Tabṣırat li-mütezzekkir ve tezkireti'l-müteșabbir, Ahmed b. } \\
\text { Yūsuf el-Kevāş̄ (A; KOHD) }\end{array}$ & Ms.or.quart. 1723 \\
\hline 958. & 28.11 .1930 & Şefìk-nāme muvażżaḥı, Mașrafzāde Meḥmed Şefīk (T; 13/4, 249) & Ms.or.oct. 2999 \\
\hline 959. & 28.11.1930 & $\begin{array}{c}\text { Zübed-i āsāru'l-mevāhib ve'l-envār, Aḥmed Șālị̣ b. 'Abdullāh } \\
(\mathrm{T} ; 13 / 5,4)\end{array}$ & Ms.or.quart. 1731 \\
\hline 960. & 28.11.1930 & 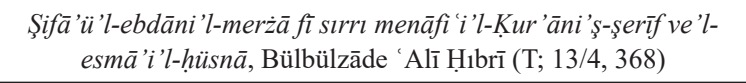 & Ms.or.oct. 3000 \\
\hline 961. & 28.11.1930 & Dìvān, Kudretī (F; 14/1, 275) & Ms.or.oct. 3300 \\
\hline 962. & 28.11 .1930 & $\dot{I}_{s ̧ r a ̄ k n ~ t}$-tevārīh, Kara Ya 'ḳūb b. İdrīs el-Ḳaramanī (A; KOHD) & Ms.or.oct. 3001 \\
\hline 963. & 28.11.1930 & 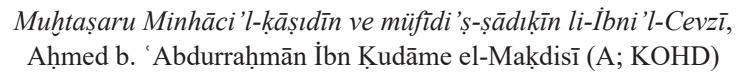 & Ms.or.oct. 3002 \\
\hline 964. & 28.11.1930 & $\begin{array}{c}\text { Es 'iletü'l-Kur'āni'l-mecīd ve ecvibetühā, Zeyneddīn Muhammed } \\
\text { er-Rāzī (A; 17A/1, 14) }\end{array}$ & Ms.or.oct. 3003 \\
\hline 965. & 28.11.1930 & $\begin{array}{l}\text { 1. Mükāşsefeti'l-kulūb (A; KOHD) } \\
\text { 2. Hurş̧̄idü'n-nevāzil (A; KOHD) }\end{array}$ & Ms.or.oct. 3004 \\
\hline 966. & 28.11.1930 & $\begin{array}{c}\text { Fevā'idü'l-Keşşāfli'z-Zemahşerē, Meḥmed b. Meḥmed el- } \\
\text { Aḳsarāyī (A; KOHD) }\end{array}$ & Ms.or.oct. 3005 \\
\hline
\end{tabular}


The Manuscripts Rescher Sold to the Berlin State Library (Reşer'in Berlin Devlet Kütüphanesi'ne Sattığı Yazmalar)

\begin{tabular}{|c|c|c|c|}
\hline Nr. & $\begin{array}{l}\text { Date } \\
\text { Tarih }\end{array}$ & $\begin{array}{c}\text { Name of Work, Name of Author (Language; Catalogue } \\
\text { Information) } \\
\text { Eser adı, Müellif adı (Dil; Katalog Bilgisi) }\end{array}$ & $\begin{array}{l}\text { Shelf nr. } \\
\text { Raf nr. }\end{array}$ \\
\hline 967. & 28.11.1930 & $\begin{array}{c}\text { Terceme-i Sittīn li-cāmi 'i’l-bustānīn, Altıparmaḳ Meḥmed Efendi } \\
\text { (T; 13/2, 179) }\end{array}$ & Ms.or.quart. 1732 \\
\hline 968. & 28.11 .1930 & $\begin{array}{c}\text { Kitābu't-Tebyīn fì beyānı milleti Şāh 'Abbās el-la ‘̀n, İbrāhīm } \\
\text { el-Hुalvetī }(\mathrm{T} ; 13 / 5,48)\end{array}$ & Ms.or.quart. 1733 \\
\hline 969. & 28.11.1930 & Tenbīh-nāme, Nidā'̄̄ (T; 13/2, 202) & Ms.or.oct. 3006 \\
\hline 970. & 28.11.1930 & Cevāhirü'l-menāḳıb (T; 13/4, 321) & Ms.or.oct. 3007 \\
\hline 971. & 28.11.1930 & 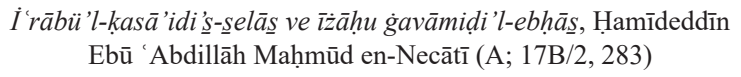 & Ms.or.oct. 3008 \\
\hline 972. & 28.11.1930 & İhtiyārāt-ı Șabūḥī, Șabūḥ̄ Aḥmed Dede (T; 13/5, 267) & Ms.or.fol. 4190 \\
\hline 973. & 28.11.1930 & 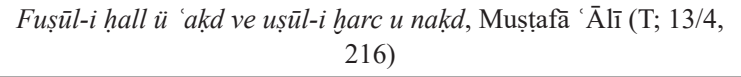 & Ms.or.oct. 3009 \\
\hline 974. & 28.11.1930 & $\begin{array}{c}\text { el-Fevā'ihü'n-nebeviye fi 's-siyeri'l-Mușțafaviye, Karaçelebizāde } \\
\text { 'Abdül'azīz Efendi }(\mathrm{T} ; 13 / 1,78)\end{array}$ & Ms.or.fol. 4191 \\
\hline 975. & 28.11.1930 & Kitābu 't-Tavż̄̄h, Mușțafā b. Zekeriyā' el-Ḳaramanī (A; KOHD) & Ms.or.oct. 3010 \\
\hline 976. & 28.11.1930 & $\begin{array}{c}\text { Kitāb-l Maḳbūl der-hāal-i ḩuyūl, Kāậ̄īāde Meḥmed b. Mușțafā } \\
\text { (T; 13/4, 429) }\end{array}$ & Ms.or.oct. 3011 \\
\hline 977. & 28.11.1930 & $\begin{array}{c}\text { el-Münebbihāt 'ale 'l-isti 'dād li-yevmi'l-mī' âad, İbn Hacer el- } \\
\text { 'Asḳalānī (A; KOHD) }\end{array}$ & Ms.or.oct. 3012 \\
\hline 978. & 23.12.1930 & $\begin{array}{c}\text { Kitābu't-Tebyīn fì ensāabi'l-Kureşiȳin, 'Abdullāh b. Ahmed İbn } \\
\text { Kudāme el-Maḳdisī (A; KOHD) }\end{array}$ & Ms.or.fol. 4192 \\
\hline 979. & 23.12.1930 & $\begin{array}{l}\text { Lübbü'l-elbāb fì 'ilmi’l-i 'rāb, 'Abdülmün 'im b. Muhammed el- } \\
\text { Eberḳ̄hì (A; 17A/1, 72) }\end{array}$ & Ms.or.oct. 3385 \\
\hline 980. & 23.12.1930 & $\begin{array}{c}\text { Mecma 'u'l-ġarā'ib fi'l-mesāha, Emrullāh b. Aḥmed-i Edirnevī } \\
(\mathrm{T} ; 13 / 4,350)\end{array}$ & Ms.or.oct. 3014 \\
\hline 981. & 23.12.1930 & $\begin{array}{l}\text { Kitābu Yenābì 'fì ma 'rifeti’l-ușūl ve’t-tefārī', Reşīdeddīn } \\
\text { Muhammed b. Maḥmūd eş-Şiblī (A; KOHD) }\end{array}$ & Ms.or.quart. 1848 \\
\hline 982. & 23.12 .1930 & $\begin{array}{l}\text { 1. Terceme-i Tuhfetü'ș-șalavāt, Oḳçıāde Mehmed Şāhī (T; 13/4, } \\
180) \\
\text { 2. Risāletü'l- 'Aşereti'l-mübeşşere (T; 13/4, 170) } \\
\text { 3. Seb 'a-i münżire (T; 13/4, 171) }\end{array}$ & Ms.or.oct. 3015 \\
\hline 983. & 23.12 .1930 & Tezkiretü'l-evliyā (T; GDA) & Ms.or.oct. 3016 \\
\hline 984. & 23.12 .1930 & Şerh-i Kașìde-i Şifā '̄, Kāmī Meḥmed Efendi (T; 13/2, 619) & Ms.or.oct. 3017 \\
\hline 985. & 23.12 .1930 & Ravżatü'l-İslām, 'Ābidī (T; 13/4, 165) & Ms.or.oct. 3018 \\
\hline
\end{tabular}


The Manuscripts Rescher Sold to the Berlin State Library (Reşer'in Berlin Devlet Kütüphanesi'ne Sattığı Yazmalar)

\begin{tabular}{|c|c|c|c|}
\hline Nr. & $\begin{array}{l}\text { Date } \\
\text { Tarih }\end{array}$ & $\begin{array}{c}\text { Name of Work, Name of Author (Language; Catalogue } \\
\text { Information) } \\
\text { Eser adı, Müellif adı (Dil; Katalog Bilgisi) }\end{array}$ & $\begin{array}{l}\text { Shelf nr. } \\
\text { Raf nr. }\end{array}$ \\
\hline 986. & 23.12 .1930 & 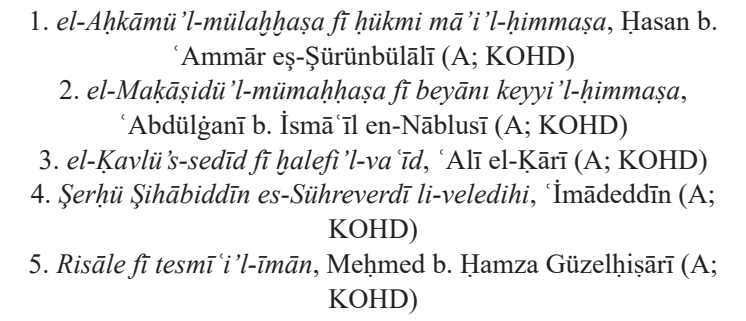 & Ms.or.oct. 3019 \\
\hline 987. & 23.12 .1930 & $\begin{array}{c}\text { et-Tezkiretü'l-mu 'ìde ve'z-žahīretü'l-hamīde, İbrāhīm b. } \\
\text { Muhammed es-Süveydī (A; KOHD) }\end{array}$ & Ms.or.oct. 3020 \\
\hline 988. & 23.12.1930 & 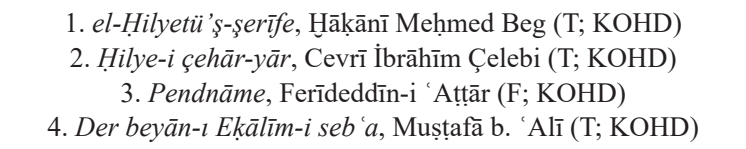 & Ms.or.oct. 3021 \\
\hline 989. & 06.03 .1931 & 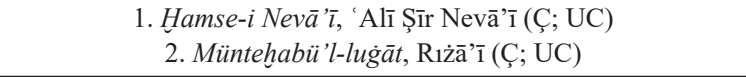 & Ms.or.quart. 1737 \\
\hline 990. & 06.03 .1931 & Tefsīrü t-Taḥrīr, Niẓāmeddīn en-Nīsābūrī (A; KOHD) & Ms.or.oct. 3031 \\
\hline 991. & 06.03 .1931 & $\begin{array}{c}\text { Kitābu'l- 'amel ve'l-elkāa fì ma 'rifeti 'ilmi'l-ușțurlāb, Ebū Ca 'fer } \\
\text { Muhammed b. Eyyūb el-Hāsib aț-Ṭaberī }(\mathrm{F} ; 14 / 1,20)\end{array}$ & Ms.or.oct. 3386 \\
\hline 992. & 11.03.1931 & $\begin{array}{l}\text { Firdevsü’l-hikme, Ebu'l-Ḥasan 'Alī b. Sehl eț-Ṭaberī (A; 17B/2, } \\
\text { 207) }\end{array}$ & Ms.or.oct. 3303 \\
\hline 993. & 11.03 .1931 & $\begin{array}{l}\text { (Muhtașar) Kitābu Tenbihhi'l-enām fì beyānı 'uluvvi maḳām } \\
\text { nebiyyinā Muḥammed 'aleyhi efḍalu ’ș-șalāt ve ezke's-selām, } \\
\text { 'Abdülcelīl b. Muhammed İbn 'Aẓūum (A; KOHD) }\end{array}$ & Ms.or.fol. 4194 \\
\hline 994. & 13.04.1931 & Dìvān, Hilālī-i Çag̉atayī (F; 14/1, 26) & Ms.or.oct. 3401 \\
\hline 995. & 13.04.1931 & Dìvān, Riyāżì-i Semerḳandī (F; 14/1, 29) & Ms.or.oct. 3440 \\
\hline 996. & 13.04.1931 & Tedbīrāt-ı pesendīde, Ebū Sehl Șāliḥzāde Nu mān (T; 13/1, 184) & Ms.or.oct. 3446 \\
\hline 997. & 13.04.1931 & Tārīh-i vak'a-i cezīre-i Saḳı, Meḥmed Emīn Vaḥīd (T; 13/1, 209) & Ms.or.oct. 3443 \\
\hline 998. & 13.04.1931 & $e z$-Zenbīl, es-Seyyid Kibrīt (A; 17B/1, 420) & Ms.or.oct. 3406 \\
\hline 999. & 13.04 .1931 & Tevārīh-i Kanije $(\mathrm{T} ; 13 / 1,146)$ & Ms.or.oct. 3442 \\
\hline 1000. & 13.04 .1931 & Enīsü’l- 'ārifin, Pīr Meḥmed ('Azmī) (T; 13/2, 182) & Ms.or.oct. 3402 \\
\hline 1001. & 13.04.1931 & $\begin{array}{c}\text { Makāale-i vak'a-i muhāṣara-i Karș fì sene 1157, Sırrī (T; 13/1, } \\
185)\end{array}$ & Ms.or.oct. 3399 \\
\hline 1002. & 13.04 .1931 & Tārīh-i feth-i Hanyā, Pīrīpaşazāde Fahrī Hëüseyn Beg (T; 13/1, & Ms.or.quart. 1862 \\
\hline 1003. & 13.04.1931 & 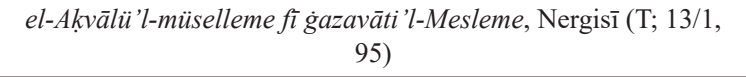 & Ms.or.oct. 3452 \\
\hline 1004. & 13.04.1931 & Lübābü'l-işārāt, Fahreddīn er-Rāzī (A; 17B/1, 228) & Ms.or.oct. 3432 \\
\hline
\end{tabular}


The Manuscripts Rescher Sold to the Berlin State Library (Reşer'in Berlin Devlet Kütüphanesi'ne Sattığı Yazmalar)

\begin{tabular}{|c|c|c|c|}
\hline Nr. & $\begin{array}{l}\text { Date } \\
\text { Tarih }\end{array}$ & $\begin{array}{c}\text { Name of Work, Name of Author (Language; Catalogue } \\
\text { Information) } \\
\text { Eser adı, Müellif adı (Dil; Katalog Bilgisi) }\end{array}$ & $\begin{array}{l}\text { Shelf nr. } \\
\text { Raf nr. }\end{array}$ \\
\hline 1005. & 13.04.1931 & $\begin{array}{l}\text { el-Cem 'beyne 'ș-șahīhayn (el-cüz'ü'r-rābi' [4 }{ }^{\text {th }} \text { vol.]), } \\
\text { Muhammed b. Ebī Nașr el-Humeydì (A; KOHD) }\end{array}$ & Ms.or.quart. 1863 \\
\hline 1006. & 13.04.1931 & Mukaddime-i Kuṭbeddīn, Kuṭ̣beddīn b. Meḥmed (T; 13/3, 23) & Ms.or.quart. 1856 \\
\hline 1007. & 13.04.1931 & Dìvān, Sa dì (A; 14/1, 325) & Ms.or.oct. 3451 \\
\hline 1008. & 10.09.1931 & 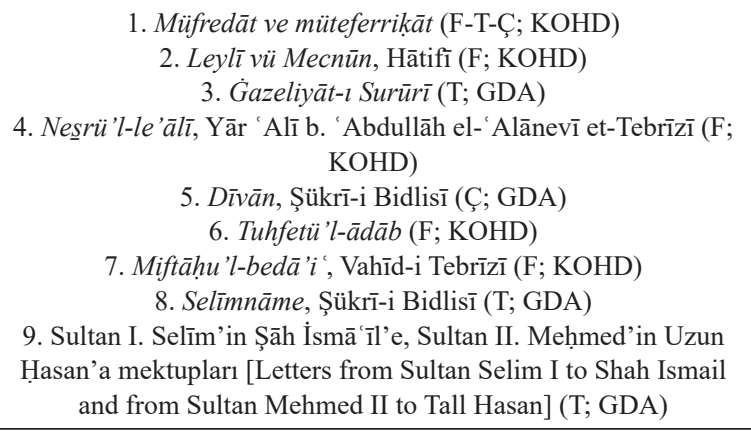 & Ms.or.oct. 3419 \\
\hline 1009. & 10.09.1931 & $\begin{array}{l}\text { Zìnetü'l-mecālis, Mecdeddīn Muhammed b. Ebī Ṭālib el-Ḥüseynī } \\
\qquad \operatorname{Mecdī~(F;~KOHD)~}\end{array}$ & Ms.or.quart. 1851 \\
\hline 1010. & 27.09.1931 & Dìvān, Yūnus Emre (T; 13/5, 207) & Ms.or.fol. 4226 \\
\hline 1011. & 27.09.1931 & $\begin{array}{l}\text { 1. Kur'ān șūrelerinün hāasșiyetleri }(\mathrm{T} ; 13 / 5,6) \\
\text { 2. Tuhfetü'l-lețā'if, Aḥmed b. 'Abdülcebbār }(\mathrm{T} ; 13 / 5,24)\end{array}$ & Ms.or.quart. 1868 \\
\hline 1012. & 27.09 .1931 & Şerā'ițü'l-fakrr ve'l-fukarā (T; 13/5, 52) & Ms.or.fol. 4224 \\
\hline 1013. & 27.09.1931 & İlāhiyāt, İbrāhīm Hูāṣṣ (T; 13/2, 363) & Ms.or.oct. 3447 \\
\hline 1014. & 27.09.1931 & $\begin{array}{l}\text { Şerhü Kașìdeti nașịha, Resūl b. Ya kūū İbn 'Ömer Siyāh (A; } \\
\text { KOHD) }\end{array}$ & Ms.or.oct. 3473 \\
\hline 1015. & 27.09.1931 & 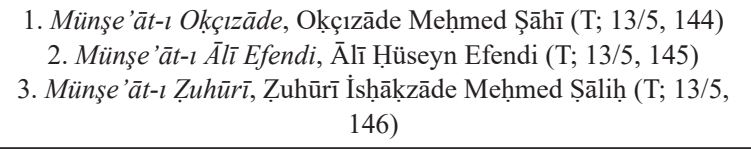 & Ms.or.quart. 1855 \\
\hline 1016. & 27.09 .1931 & $\begin{array}{l}\text { 1. Dìvāan, Bezcizāde Muhỵī (T; 13/3, 233) } \\
\text { 2. Dìvān, Üftāde Meḥmed Muḥyiddīn }(\mathrm{T} ; 13 / 3,229) \\
\text { 3. Vașiyet-i Resūlullāh }(\mathrm{T} ; 13 / 3,19)\end{array}$ & Ms.or.oct. 3438 \\
\hline 1017. & 27.09 .1931 & $\begin{array}{l}\text { 1. Hall-i müşkilāt, Hasan (T; 13/4, 280) } \\
\text { 2. Kitābu Mecmū 'ati'l-lețā' 'if fì bāabi’l-ma 'ârif, Cemāli İbrāhīm b. } \\
\text { Mușțafā (T; 13/4, 281) } \\
\text { 3. Inşā'iyāt }(\mathrm{T} ; 13 / 4,306)\end{array}$ & Ms.or.oct. 3431 \\
\hline 1018. & 27.09 .1931 & 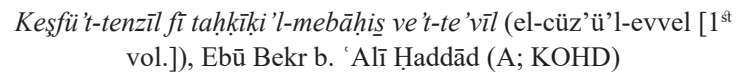 & Ms.or.oct. 3429 \\
\hline
\end{tabular}


The Manuscripts Rescher Sold to the Berlin State Library (Reşer'in Berlin Devlet Kütüphanesi'ne Sattığı Yazmalar)

\begin{tabular}{|c|c|c|c|}
\hline Nr. & $\begin{array}{l}\text { Date } \\
\text { Tarih }\end{array}$ & $\begin{array}{c}\text { Name of Work, Name of Author (Language; Catalogue } \\
\text { Information) } \\
\text { Eser adı, Müellif adı (Dil; Katalog Bilgisi) }\end{array}$ & $\begin{array}{l}\text { Shelf nr. } \\
\text { Raf nr. }\end{array}$ \\
\hline 1019. & 27.09 .1931 & 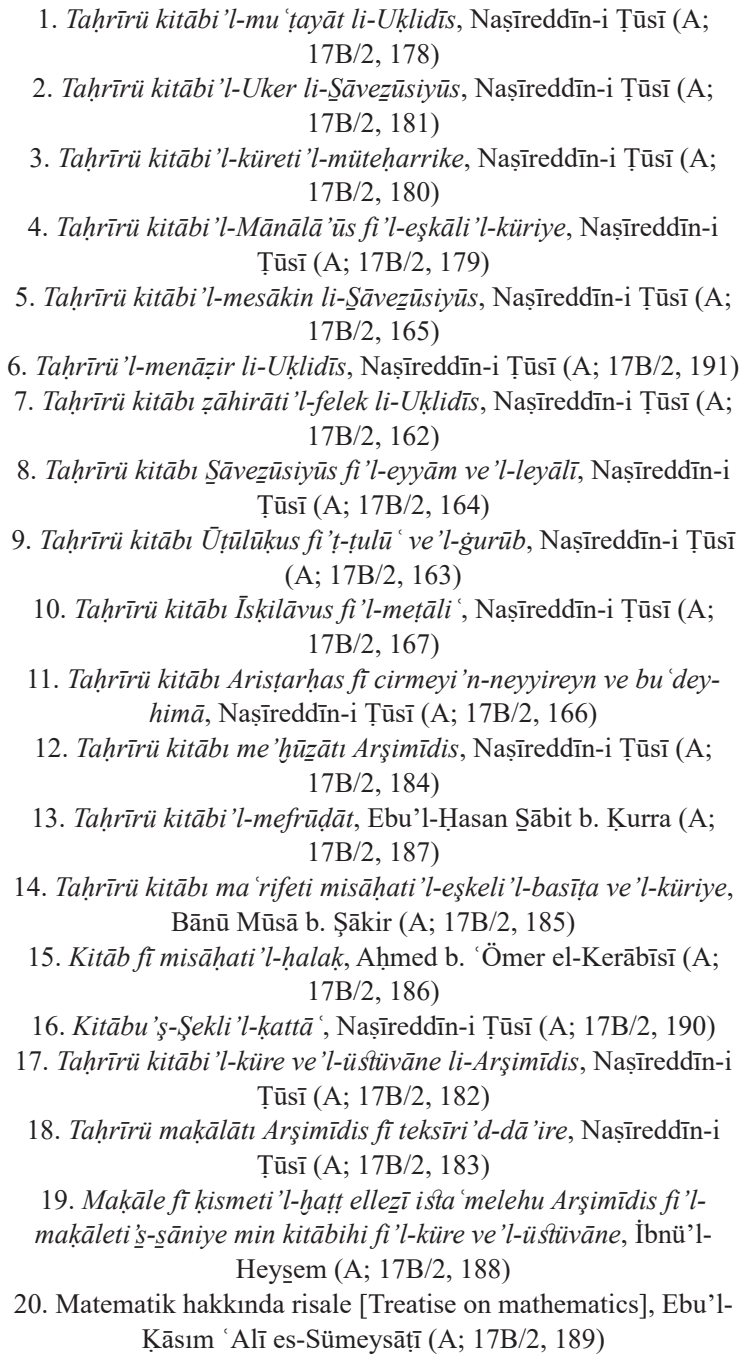 & Ms.or.quart. 1867 \\
\hline 1020. & 27.09 .1931 & Kִānūnu'l-vizāre, Ebu'l-Ḥasan el-Māverdī (A; 17B/1, 246) & Ms.or.oct. 3433 \\
\hline 1021. & 27.09.1931 & $\begin{array}{l}\text { Mi yāru'l-mürīdīn, Kuṭbeddīn Ebū Muhammed el-Mekkī (A; } \\
\text { 17B/1, 105) }\end{array}$ & Ms.or.oct. 3434 \\
\hline 1022. & 27.09.1931 & Dìvān, 'Abdurraḥmān Cāmī (F; 14/1, 377) & Ms.or.oct. 3444 \\
\hline 1023. & 27.10 .1931 & Tevārīh-i Maḥmūd Paşa-yı velī (T; 13/4, 263) & Ms.or.oct. 3487 \\
\hline
\end{tabular}


The Manuscripts Rescher Sold to the Berlin State Library (Reşer'in Berlin Devlet Kütüphanesi'ne Sattığı Yazmalar)

\begin{tabular}{|c|c|c|c|}
\hline Nr. & $\begin{array}{l}\text { Date } \\
\text { Tarih }\end{array}$ & $\begin{array}{c}\text { Name of Work, Name of Author (Language; Catalogue } \\
\text { Information) } \\
\text { Eser adı, Müellif adı (Dil; Katalog Bilgisi) }\end{array}$ & $\begin{array}{l}\text { Shelf nr. } \\
\text { Raf nr. }\end{array}$ \\
\hline 1024. & 27.10 .1931 & Dīvānçe, 'Ābid Maḥmūd Meḥmed (T; 13/2, 305) & Ms.or.oct. 3491 \\
\hline 1025. & 27.10 .1931 & $\begin{array}{c}\text { Meḥmed Șādı̣ Erzincān̄i: } \\
\text { 1. Terbiye-nāme }(\mathrm{T} ; 13 / 2,100) \\
\text { 2. Risāle-i Ma rifet-i nefs }(\mathrm{T} ; 13 / 2,158)\end{array}$ & Ms.or.oct. 3486 \\
\hline 1026. & 27.10 .1931 & Şeref-i siyādet, Seyyid Seyfullāh (T; 13/4, 187) & Ms.or.oct. 3484 \\
\hline 1027. & 27.10 .1931 & $\begin{array}{l}\text { 1. Te'dībü'l-mütemerrideyn fì hakki'l-ebeveyn, 'Abdülahạad Nūrī } \\
\text { es-Sivasī }(\mathrm{T} ; 13 / 4,24) \\
\text { 2. Risāletü'd-deverān li-gavsi hāze 'z-zamān }(\mathrm{T} ; 13 / 2,174)\end{array}$ & Ms.or.oct. 3485 \\
\hline 1028. & 27.10 .1931 & $\begin{array}{l}\text { 1. Miftāhu'n-necāt, Jende-pīl Aḥmed-i Cām (F; KOHD) } \\
\text { 2. 'Umdetü'l-İslām, Ebū Țāhir-i Multānī (F; KOHD) }\end{array}$ & Ms.or.oct. 3495 \\
\hline 1029. & 27.10 .1931 & 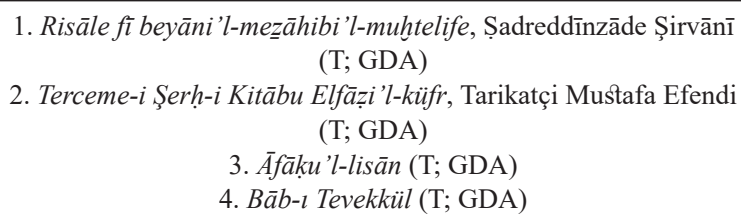 & Ms.or.oct. 3492 \\
\hline 1030. & 16.11 .1931 & Kitābu't-Tenezzülāti'l-mevșiliye, İbnü'l-'Arabī (A; KOHD) & Ms.or.oct. 3478 \\
\hline 1031. & 16.11 .1931 & $\begin{array}{c}\text { Muhtașaru Esbābi'n-nüzūl, Burhāneddīn Ebu'l- 'Abbās el- } \\
\text { Ca'berī }(\mathrm{A} ; 17 \mathrm{~B} / 1,11)\end{array}$ & Ms.or.oct. 3578 \\
\hline 1032. & 16.11 .1931 & 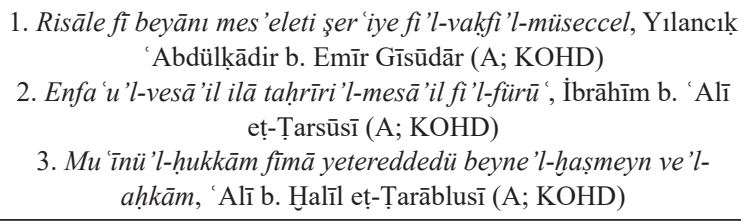 & Ms.or.quart. 1927 \\
\hline 1033. & 16.11.1931 & $\begin{array}{c}\text { el-Muğnī fì uṣūli’l-fiḳh, 'Ömer b. Muhammed el-Ḩabbāzì (A; } \\
\text { KOHD) }\end{array}$ & Ms.or.quart. 1920 \\
\hline 1034. & 16.11 .1931 & 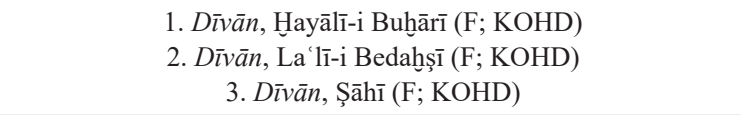 & Ms.or.oct. 3501 \\
\hline 1035. & 16.11 .1931 & Fetāve'n-Nevevī, 'Alī b. İbrāhīm İbn el- Atțāa (A; KOHD) & Ms.or.oct. 3502 \\
\hline 1036. & 21.01 .1932 & $\begin{array}{c}\text { Sifrü's-sa 'āde ve sefirü'l-ifāde, 'Alemeddīn es-Sehāvī (A; 17B/2, } \\
243)\end{array}$ & Ms.or.oct. 3582 \\
\hline 1037. & 21.01 .1932 & 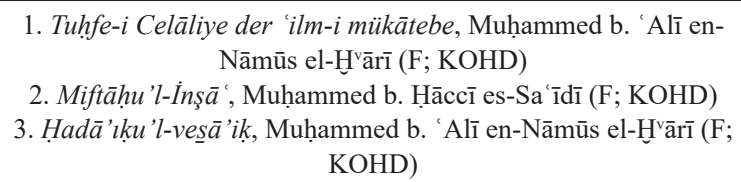 & Ms.or.oct. 3512 \\
\hline
\end{tabular}


The Manuscripts Rescher Sold to the Berlin State Library (Reşer'in Berlin Devlet Kütüphanesi'ne Sattığı Yazmalar)

\begin{tabular}{|c|c|c|c|}
\hline Nr. & $\begin{array}{l}\text { Date } \\
\text { Tarih }\end{array}$ & $\begin{array}{c}\text { Name of Work, Name of Author (Language; Catalogue } \\
\text { Information) } \\
\text { Eser adı, Müellif adı (Dil; Katalog Bilgisi) }\end{array}$ & $\begin{array}{l}\text { Shelf nr. } \\
\text { Raf nr. }\end{array}$ \\
\hline 1038. & 4.06 .1932 & $\begin{array}{l}\text { 1. el- 'Akīdetü'l-Māturīdiye, Ebū Manșūr Muhammed el-Māturīdīi } \\
\text { (A; KOHD) } \\
\begin{array}{l}\text { 2. Ádābü'l-mürīdīn fi 't-tașavvuf, 'Abdülkāhir b. 'Abdullāh es- } \\
\text { Sühreverdī (A; KOHD) }\end{array}\end{array}$ & Ms.or.oct. 3566 \\
\hline 1039. & 15.03 .1933 & $\begin{array}{l}\text { Hilyetü'l-evliyā' ve țabaḳātu'l-asfiyā̄', Ebū Nu aym Ahmed b. } \\
\text { 'Abdullāh }(\mathrm{A} ; 17 \mathrm{~A} / 2,130)\end{array}$ & Ms.or.oct. 3553 \\
\hline 1040. & 15.03 .1933 & Sa'ādet-nāme, Cāmī (T; 13/1, 249) & Ms.or.quart. 1904 \\
\hline 1041. & 15.03 .1933 & Mecmū'a-i eş 'ār $(\mathrm{T} ; 13 / 3,264)$ & Ms.or.oct. 3520 \\
\hline 1042. & 15.03 .1933 & Dìvān, Cemālī (F; KOHD) & Ms.or.oct. 3572 \\
\hline 1043. & 15.03 .1933 & Hamza-nāme (F; KOHD) & Ms.or.quart. 1902 \\
\hline 1044. & 15.03 .1933 & Terceme-i Enīsü’l-münkaṭi '̌n $(\mathrm{T} ; 13 / 3,13)$ & Ms.or.oct. 3569 \\
\hline 1045. & 25.03 .1933 & Kitāb fìhi ehādis ve ādāb ve hikem ve ahbāar $(\mathrm{A} ; 17 \mathrm{~A} / 1,91)$ & Ms.or.oct. 3545 \\
\hline 1046. & 25.03 .1933 & Tedbīrü'l-mevlūd, Şifâ'̄i Şa 'bān b. Aḥmed (T; 13/4, 405) & Ms.or.oct. 3544 \\
\hline 1047. & 25.03 .1933 & Mekātib, Şeyh Murādī Efendi (T-A; UC-GDA) & Ms.or.oct. 3546 \\
\hline 1048. & 25.03 .1933 & $\begin{array}{c}\text { Kitābu'l-Minaḥi'l-ilāhiyāt bi-Şerhhi Delā'ili'l-hূayrāt, Süleymān } \\
\text { b. 'Ömer el-Cemel el- 'Uceylī (A; KOHD) }\end{array}$ & Ms.or.oct. 3547 \\
\hline 1049. & 25.03 .1933 & 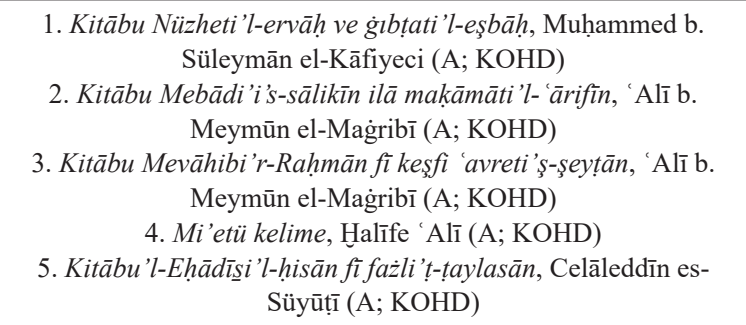 & Ms.or.oct. 3549 \\
\hline 1050. & 25.03 .1933 & $\begin{array}{l}\text { 1. Hallü şukūk fì Kitābi Macisțī fi'l-hey'e, İbnü'l-Heyșem (A; } \\
\text { UC) } \\
\text { 2. Şerḥü Muhtașar fì ma 'rifeti 't-taḳāvìm li-Ṭūsì (A; UC) }\end{array}$ & Ms.or.oct. 3548 \\
\hline 1051. & 31.03 .1933 & 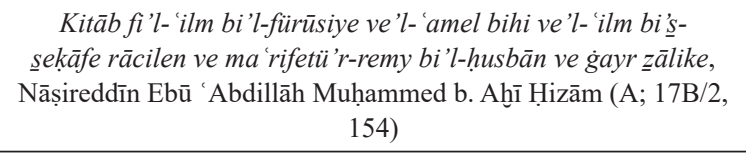 & Ms.or.quart. 1906 \\
\hline 1052. & 28.04 .1933 & 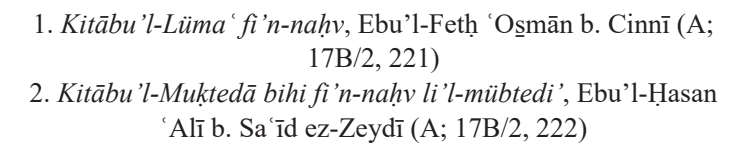 & Ms.or.oct. 3538 \\
\hline 1053. & 28.04 .1933 & $\begin{array}{l}\text { el-Vakfu's-Secāvendī, Muhammed b. Țayfūr es-Secāvendī (A; } \\
\text { 17A/1,9) }\end{array}$ & Ms.or.oct. 3542 \\
\hline
\end{tabular}


The Manuscripts Rescher Sold to the Berlin State Library (Reşer'in Berlin Devlet Kütüphanesi'ne Sattığı Yazmalar)

\begin{tabular}{|c|c|c|c|}
\hline Nr. & $\begin{array}{l}\text { Date } \\
\text { Tarih }\end{array}$ & $\begin{array}{c}\text { Name of Work, Name of Author (Language; Catalogue } \\
\text { Information) } \\
\text { Eser adı, Müellif adı (Dil; Katalog Bilgisi) }\end{array}$ & $\begin{array}{l}\text { Shelf nr. } \\
\text { Raf nr. }\end{array}$ \\
\hline 1054. & 28.04.1933 & 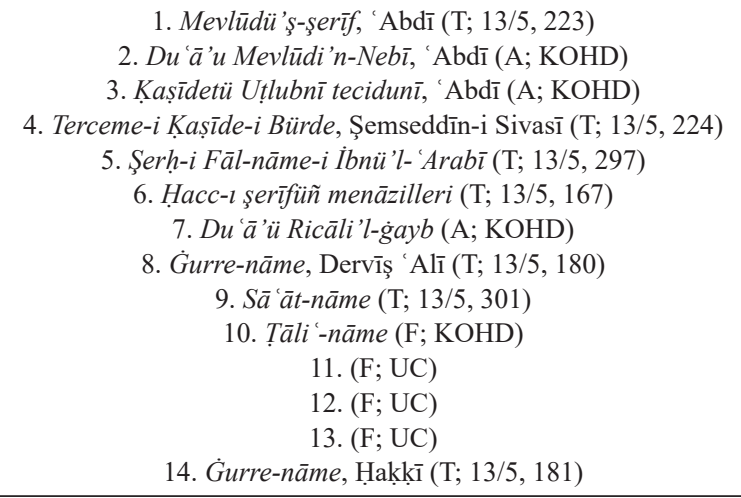 & Ms.or.quart. 1908 \\
\hline 1055. & 09.06 .1933 & el-Cāmi 'ü’ș-șag̀̄̄r $r$ Șadrü’ş-şehīd (A; KOHD) & Ms.or.oct. 3560 \\
\hline 1056. & 09.06 .1933 & $\begin{array}{l}\text { 1. Huțab (A; KOHD) } \\
\text { 2. er-Ravżu'n-naż̄ir fì 'ilmi 't-težkīr, Ebū Bekr 'Abdurraḥman b. } \\
\text { 'Alī İbn en-Neccār ed-Dimaşḳī (A; KOHD) }\end{array}$ & Ms.or.quart. 1910 \\
\hline 1057. & 09.06 .1933 & $\begin{array}{c}\text { Ünsü'(İns)l-munkați 'ìn ve riyāżu’s-sālikīn ilā 'ibādeti rabbi'l- } \\
\text { 'älemīn, el-Mu'āfā b. İsmā îl el-Mevșilī (A; KOHD) }\end{array}$ & Ms.or.quart. 1911 \\
\hline 1058. & 09.06 .1933 & Aḥkāmü'l-Kur 'ān, Aḥmed b. 'Alī el-Cașșāṣ (A; KOHD) & Ms.or.quart. 1905 \\
\hline 1059. & 09.06 .1933 & $\begin{array}{c}\text { Lübābü't-tefāsīr (en-nıșfu'l-evvel [1 } 1^{\text {st }} \text { part]), Mahmūd b. Hamza } \\
\text { el-Kirmānī (A; KOHD) }\end{array}$ & Ms.or.oct. 3561 \\
\hline 1060. & 09.06 .1933 & $\begin{array}{c}\text { el-Esmā' '̈̈'l-mübheme fi'l-enbā'ì'l-muhkeme, Ebū Bekr Ahmed } \\
\text { el-Hुațīb el-Bağdādī (A; 17A/1, 20) }\end{array}$ & Ms.or.oct. 3574 \\
\hline 1061. & 09.06 .1933 & $\begin{array}{c}\text { İşāäu’s-sālik ilā ḥalli Elfiyeti İbn Mālik, Burhāneddīn Ebū İsḥāḳ } \\
\text { İbrāhīm İbn Kayyım el-Cevziye }(\mathrm{A} ; 17 \mathrm{~A} / 1,70)\end{array}$ & Ms.or.oct. 3573 \\
\hline 1062. & 09.06 .1933 & 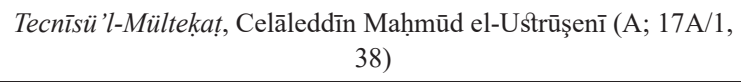 & Ms.or.oct. 3537 \\
\hline 1063. & 09.06 .1933 & el-Müktefā, Ebū 'Amr ed-Dānī (A; 17A/1, 6) & Ms.or.oct. 3536 \\
\hline 1064. & 09.06 .1933 & Mecmū 'a, Eyyūbī Meḥmed Emīn Efendi (A; 17B/1, 421) & Ms.or.oct. 3541 \\
\hline 1065. & 09.06 .1933 & 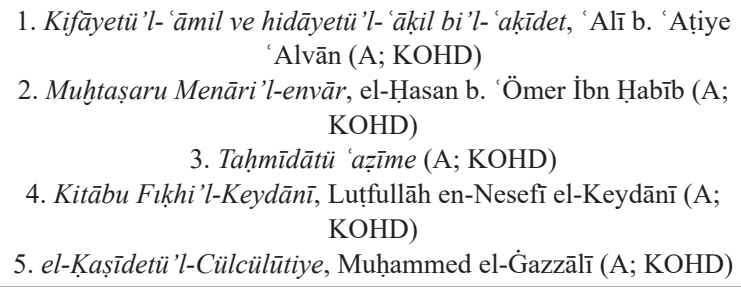 & Ms.or.oct. 3535 \\
\hline 1066. & 09.06 .1933 & $\begin{array}{l}\text { Tìcānu feżā' ’ili 'ş-şuhūr, Ḥāmid b. Yūsuf el-Bandırmavī (A; } \\
\text { KOHD) }\end{array}$ & Ms.or.oct. 3550 \\
\hline
\end{tabular}


The Manuscripts Rescher Sold to the Berlin State Library (Reşer'in Berlin Devlet Kütüphanesi'ne Sattığı Yazmalar)

\begin{tabular}{|c|c|c|c|}
\hline Nr. & $\begin{array}{l}\text { Date } \\
\text { Tarih }\end{array}$ & $\begin{array}{c}\text { Name of Work, Name of Author (Language; Catalogue } \\
\text { Information) } \\
\text { Eser adı, Müellif adı (Dil; Katalog Bilgisi) }\end{array}$ & $\begin{array}{l}\text { Shelf nr. } \\
\text { Raf nr. }\end{array}$ \\
\hline 1067. & 09.06.1933 & $\begin{array}{c}\text { el-Fethu'l-karīb li-ḥażreti'l-meliki'l-mücīb, Muḥammed Berekāt } \\
\text { b. es-Seyyid Aḥmed Efendi (A; KOHD) }\end{array}$ & Ms.or.oct. 3534 \\
\hline 1068. & 16.09 .1933 & Dìvān, Hikmet (T; 13/2, 362) & Ms.or.oct. 3630 \\
\hline 1069. & 16.09 .1933 & $\begin{array}{l}\text { 1. Kitābu'l-Kırānāt, Ebū Ma 'şer Ca 'fer b. Muhammed (A; } \\
\text { KOHD) } \\
\text { 2. Keyfiyetü'l-hüum 'alā tahāāvīli sini'l- 'ālem, Yahyā b. } \\
\text { Muhammed İbn Ebi’ş-Şükr (A; KOHD) }\end{array}$ & Ms.or.oct. 3628 \\
\hline 1070. & 16.09.1933 & et-Teysīr fi'l-kurā'āti’'s-seb 'a, Ebū 'Amr ed-Dānī (A; 17A/1, 12) & Ms.or.oct. 3629 \\
\hline 1071. & 16.09 .1933 & $\begin{array}{l}\text { el-İşrāf 'alā fażli’l-eşrā } f \text {, İbrāhīm el-Hasanī es-Semhūdī (A; } \\
\text { 17B/1, 494) }\end{array}$ & Ms.or.oct. 3626 \\
\hline 1072. & 16.09 .1933 & Ravżatü'l-aḥbāb, Sā'ilī (F; 14/1, 166) & Ms.or.oct. 3627 \\
\hline 1073. & 10.11 .1933 & Hayātu'l-hayavān, Muhammed b. Mūsā ed-Demīrī (A; KOHD) & Ms.or.quart. 1930 \\
\hline 1074. & 24.09.1934 & $\begin{array}{l}\text { Kitābu Tezkireti's-sāmi 've 'l-mütekellim fì edebi'l- 'ilm ve'l- } \\
\text { müte 'allim, Muhammed b. İbrāhīm İbn Cemā'a (A; KOHD) }\end{array}$ & Ms.or.quart. 1936 \\
\hline 1075. & 24.09.1934 & $\begin{array}{l}\text { 1. Dìvān, Nihānī Fāżı̇l b. 'Abdullāh (T; 13/3, 227) } \\
\text { 2. Risāle-i 'Arūù, Nuṭ̣̂̄ (T; 13/3, 224) }\end{array}$ & Ms.or.oct. 3636 \\
\hline 1076. & 24.09 .1934 & Kitābu'l-Akțāa, Șı dḳ̄i (T; 13/4, 374) & Ms.or.oct. 3638 \\
\hline 1077. & 24.09 .1934 & $\begin{array}{l}\text { Hāşsiye 'ale 'l-Miṣbāh fì şerhìi'l-Miftāh, Emīr Hasan er-Rūmī (A; } \\
17 \mathrm{~B} / 1,321)\end{array}$ & Ms.or.oct. 3637 \\
\hline 1078. & 24.09 .1934 & $\begin{array}{c}\text { Kenzü'l-ma 'ānī fì şerhi Hırzi'l-emānì, İbrāhīm b. 'Ömer el- } \\
\text { Ca berī (A; KOHD) }\end{array}$ & Ms.or.quart. 1937 \\
\hline 1079. & 16.11 .1934 & $\begin{array}{c}\text { Münyetü'l-ebrār ve ġunyetü'l-ahyār, 'Abdurrahīm-i Karahișārī } \\
(\mathrm{T} ; 13 / 5,64)\end{array}$ & Ms.or.oct. 3649 \\
\hline 1080. & 16.11 .1934 & Hüsrev-nāme (T; GDA) & Ms.or.quart. 1944 \\
\hline 1081. & 16.11 .1934 & Süleymān-nāme (muhtașar), Firdevsī-i Rumī (T; 13/1, 53) & Ms.or.quart. 1945 \\
\hline 1082. & 21.12 .1934 & Resā'il, 'Alī el-Ḳārī (A; UC) & Ms.or.quart. 1947 \\
\hline 1083. & 21.12 .1934 & $\begin{array}{c}\text { Medārikü't-tenzīl ve hakāàiku 't-te'vīl, 'Abdullāh b. Ahmed en- } \\
\text { Nesefì (A; KOHD) }\end{array}$ & Ms.or.quart. 1946 \\
\hline 1084. & 21.12.1934 & Dīvān, Mīrzā Muhammad Nigārī (F; KOHD) & Ms.or.oct. 3654 \\
\hline 1085. & 21.12.1934 & $\begin{array}{l}\text { İkbālnāme-i Cihāngīrī, Muhammed Şerīf b. Dūst Muhạammed (F; } \\
16 / 1,78)\end{array}$ & Ms.or.quart. 1948 \\
\hline
\end{tabular}


The Manuscripts Rescher Sold to the Berlin State Library (Reşer'in Berlin Devlet Kütüphanesi'ne Sattığı Yazmalar)

\begin{tabular}{|c|c|c|c|}
\hline Nr. & $\begin{array}{l}\text { Date } \\
\text { Tarih }\end{array}$ & $\begin{array}{c}\text { Name of Work, Name of Author (Language; Catalogue } \\
\text { Information) } \\
\text { Eser adı, Müellif adı (Dil; Katalog Bilgisi) }\end{array}$ & $\begin{array}{l}\text { Shelf nr. } \\
\text { Raf nr. }\end{array}$ \\
\hline 1086. & 21.12 .1934 & 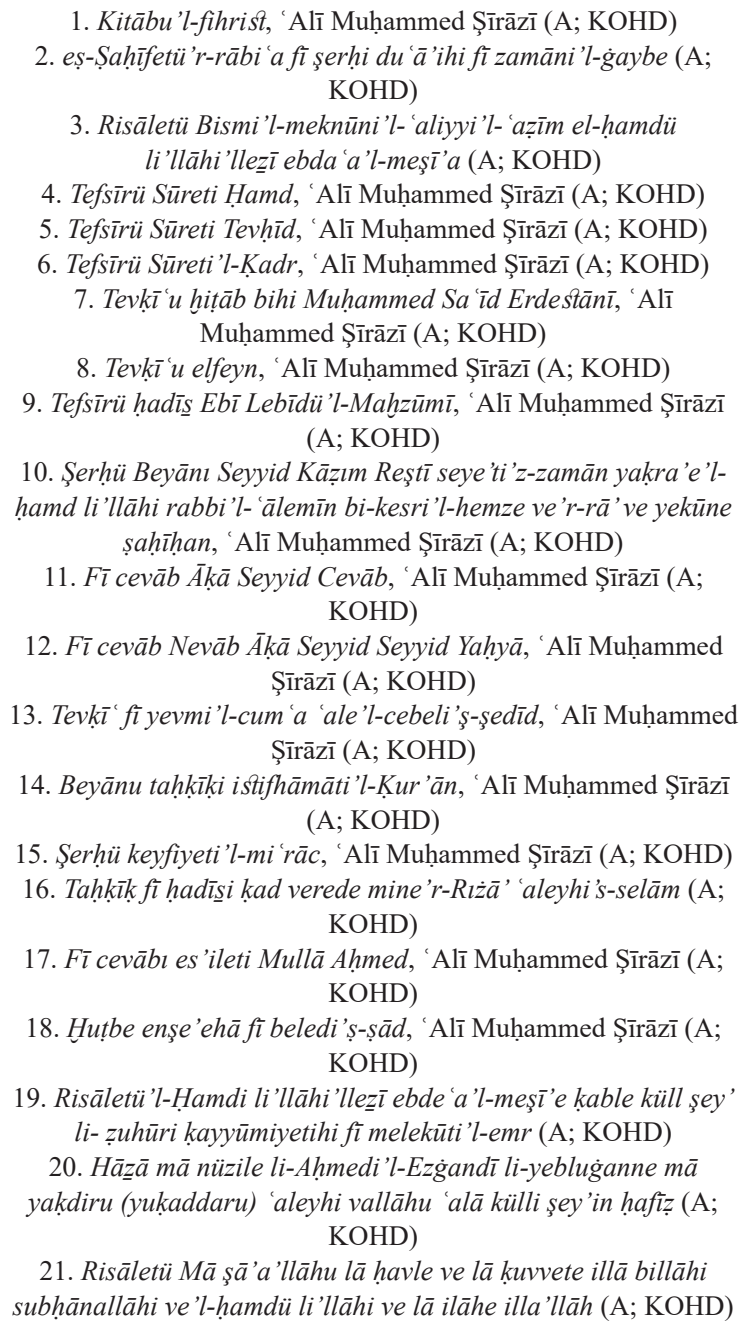 & Ms.or.oct. 3655 \\
\hline 1087. & 21.12.1934 & Min şecereti'l-ḥamrā'en-nābite fi arżi'l-hażrāa' (A; KOHD) & Ms.or.oct. 3656 \\
\hline 1088. & 21.12 .1934 & Beyān-ı Fārsī, 'Alī Muḥammed Şīrāzī (F; KOHD) & Ms.or.oct. 3657 \\
\hline 1089. & 21.12 .1934 & Ta rīf-i şerī'at-i beyān (F; KOHD) & Ms.or.oct. 3658 \\
\hline 1090. & 21.12 .1934 & $\begin{array}{l}\text { Kitābu'l-Muhtārāt, Ebu'l-Hasan 'Alī b. Ahmed İbn Hübel (A; } \\
\text { KOHD) }\end{array}$ & Ms.or.quart. 1950 \\
\hline 1091. & 21.12 .1934 & $\begin{array}{c}\text { Telhīṣü'l-akvāal fì tahkīiki ahvāli'r-ricāal, Muhammed b. 'Alī el- } \\
\text { Esterābādī (A; KOHD) }\end{array}$ & Ms.or.quart. 1949 \\
\hline
\end{tabular}



The Manuscripts Rescher Sold to the Berlin State Library (Reşer'in Berlin Devlet
Kütüphanesi'ne Sattığı Yazmalar)

\begin{tabular}{|c|c|c|c|}
\hline Nr. & $\begin{array}{l}\text { Date } \\
\text { Tarih }\end{array}$ & $\begin{array}{c}\text { Name of Work, Name of Author (Language; Catalogue } \\
\text { Information) } \\
\text { Eser adı, Müellif adı (Dil; Katalog Bilgisi) }\end{array}$ & $\begin{array}{l}\text { Shelf nr. } \\
\text { Raf nr. }\end{array}$ \\
\hline 1092. & 21.12 .1934 & Risāle fì keş̧fi'ż-żamā'ir ve 'l-ḩafiyāt, Bābā Şirvānī (F; KOHD) & Ms.or.oct. 3659 \\
\hline 1093. & 21.12 .1934 & Tasavvuf hakkında risaleler [Treatises on Sufism] (F; UC) & Ms.or.quart. 1951 \\
\hline 1094. & 21.12 .1934 & Rubā'iyāt, 'Ömer Hayyām (F; KOHD) & Ms.or.oct. 3660 \\
\hline 1095. & 21.12 .1934 & $\begin{array}{l}\text { et-Takrīb fì esrāri t-terkīb, Eydemür b. 'Alī el-Cildekī (A; } \\
\text { KOHD) }\end{array}$ & Ms.or.oct. 3661 \\
\hline 1096. & 21.12 .1934 & Niyāzü’l-müznibīn, 'Alī Znelīlī (T; 13/5, 257) & Ms.or.quart. 1952 \\
\hline 1097. & 09.04 .1935 & Tercemetü'l-İ 'lām bi-a 'lāmi beledi 'llāhi 'l-harām, Bāḳī (T; 13/1, & Ms.or.oct. 3669 \\
\hline 1098. & 09.04 .1935 & $\begin{array}{l}\text { Karaçelebizāde 'Abdül'azīz Efendi: } \\
\text { 1. Ravżatü'l-ebrār }(\mathrm{T} ; 13 / 1,33) \\
\text { 2. Zeyl-i tārīh }(\mathrm{T} ; 13 / 1,35)\end{array}$ & Ms.or.quart. 1978 \\
\hline 1099. & 09.04 .1935 & Şerḥü'l-Hidāye (A; KOHD) & Ms.or.quart. 1982 \\
\hline 1100. & 09.04 .1935 & Nigāristān, Kemālpaşazāde (F; 14/1, 338) & Ms.or.quart. 1983 \\
\hline 1101. & 09.04 .1935 & 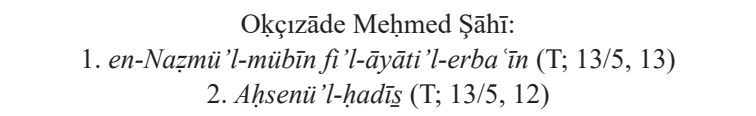 & Ms.or.quart. 1964 \\
\hline 1102. & 09.04 .1935 & 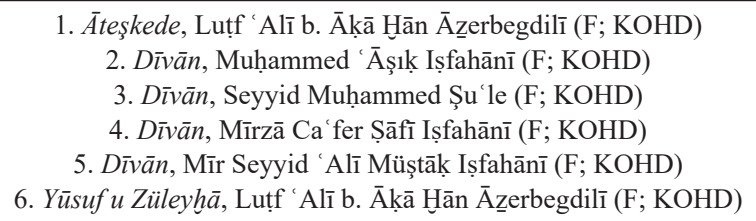 & Ms.or.quart. 1984 \\
\hline 1103. & 09.04 .1935 & Sefāret-nāme, Seyyid 'Abdürrahīm Muhiib Efendi (T; 13/1, 220) & Ms.or.quart. 1977 \\
\hline 1104. & 09.04 .1935 & Fezleke, Kātib Çelebi (T; 13/1, 162) & Ms.or.quart. 1979 \\
\hline 1105. & 09.04 .1935 & $\begin{array}{c}\text { Tārīh-i Cizyedārzāde, Cizyedārzāde Aḥmed Bahā'eddīn (T; 13/1, } \\
136)\end{array}$ & Ms.or.quart. 1971 \\
\hline 1106. & 09.04 .1935 & Behcetü t-tevārīh, Mușțafā $(\mathrm{T} ; 13 / 1,13)$ & Ms.or.quart. 1972 \\
\hline 1107. & 09.04 .1935 & $\begin{array}{l}\text { Țabakātü'l-memālik ve derecātü'l-mesālik, Celālzāde Mușṭafā } \\
\text { Çelebi }(\mathrm{T} ; 13 / 1,144)\end{array}$ & Ms.or.quart. 1961 \\
\hline 1108. & 09.04 .1935 & Terceme-i Şevāhidü'n-nübüvve, Lāmi 'ì Çelebi (T; 13/5, 17) & Ms.or.quart. 1966 \\
\hline 1109. & 09.04 .1935 & $\begin{array}{c}\text { er-Ravżatü'l-behiye fi şerhịi'l-Lüm 'ati'd-Dimaşkiye, Zeyneddīn b. } \\
\text { 'Alī el-'Āmilī eş-Şehīdü's-S-Sānī (A; KOHD) }\end{array}$ & Ms.or.quart. 1956 \\
\hline 1110. & 09.04 .1935 & 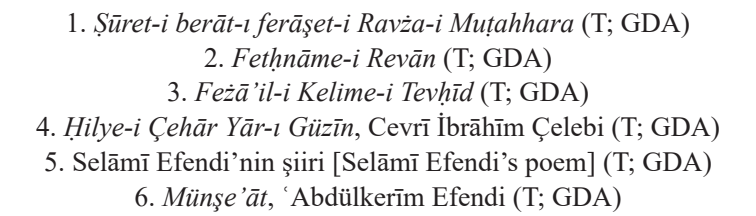 & Ms.or.quart. 1957 \\
\hline
\end{tabular}


The Manuscripts Rescher Sold to the Berlin State Library (Reșer'in Berlin Devlet Kütüphanesi'ne Sattığı Yazmalar)

\begin{tabular}{|c|c|c|c|}
\hline Nr. & $\begin{array}{l}\text { Date } \\
\text { Tarih }\end{array}$ & $\begin{array}{c}\text { Name of Work, Name of Author (Language; Catalogue } \\
\text { Information) } \\
\text { Eser adı, Müellif adı (Dil; Katalog Bilgisi) }\end{array}$ & $\begin{array}{l}\text { Shelf nr. } \\
\text { Raf nr. }\end{array}$ \\
\hline 1111. & 09.04 .1935 & 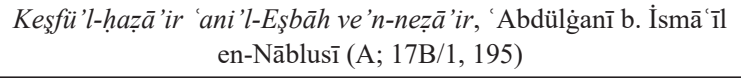 & Ms.or.oct. 3671 \\
\hline 1112. & 09.04 .1935 & Menāẓirü'l-inşā', Maḥmūd Gāvān (F-Ç-T; KOHD) & Ms.or.oct. 3672 \\
\hline 1113. & 09.04 .1935 & 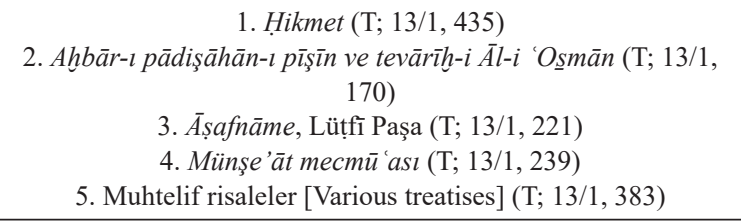 & Ms.or.oct. 3667 \\
\hline 1114. & 09.04 .1935 & Tārīh-i Mıșr-ı Kāhire (T; 13/1, 113) & Ms.or.quart. 1973 \\
\hline 1115. & 09.04 .1935 & Sefinetü'l-vüzerāa, Șaḥ̣āflar Şeyhizāde Ahmmed Nazīf (T; 13/1, & Ms.or.oct. 3668 \\
\hline 1116. & 09.04 .1935 & Ahkām-l sāl, Aḥmed Sa dullāh (T; 13/1, 406) & Ms.or.quart. 1974 \\
\hline 1117. & 09.04 .1935 & Tedbīr-i iksīr , Seḥābī Ḥüsāmeddīn Efendi (T; 13/5, 54) & Ms.or.quart. 1967 \\
\hline 1118. & 09.04 .1935 & 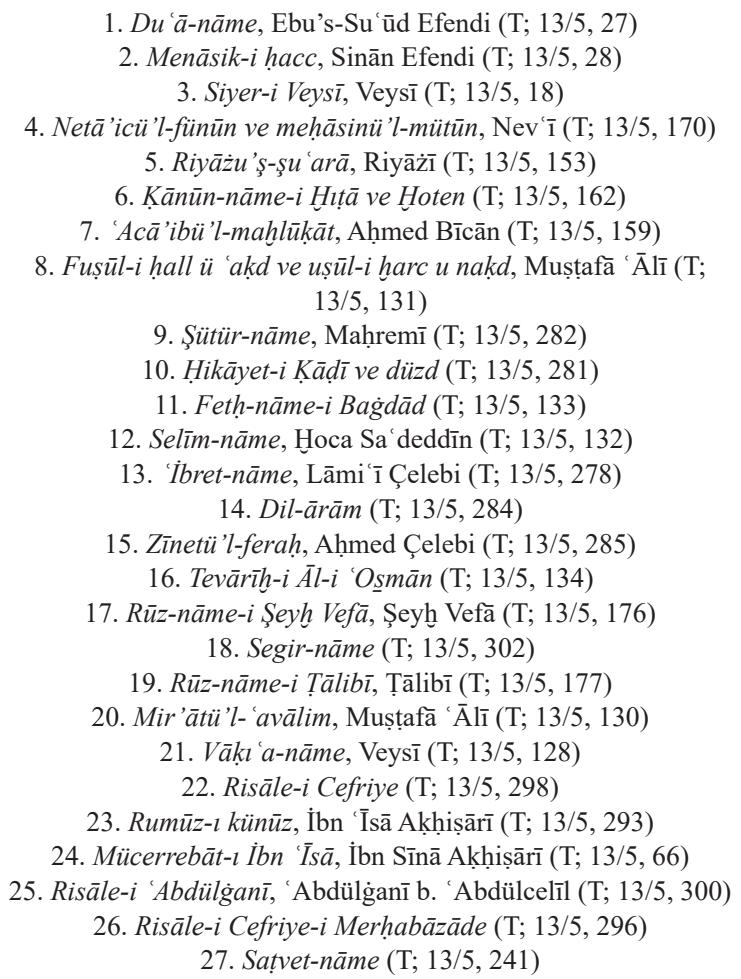 & Ms.or.quart. 1988 \\
\hline
\end{tabular}


The Manuscripts Rescher Sold to the Berlin State Library (Reşer'in Berlin Devlet Kütüphanesi'ne Sattığı Yazmalar)

\begin{tabular}{|c|c|c|c|}
\hline Nr. & $\begin{array}{l}\text { Date } \\
\text { Tarih }\end{array}$ & $\begin{array}{c}\text { Name of Work, Name of Author (Language; Catalogue } \\
\text { Information) } \\
\text { Eser adı, Müellif adı (Dil; Katalog Bilgisi) }\end{array}$ & $\begin{array}{l}\text { Shelf nr. } \\
\text { Raf nr. }\end{array}$ \\
\hline 1118. & 09.04 .1935 & 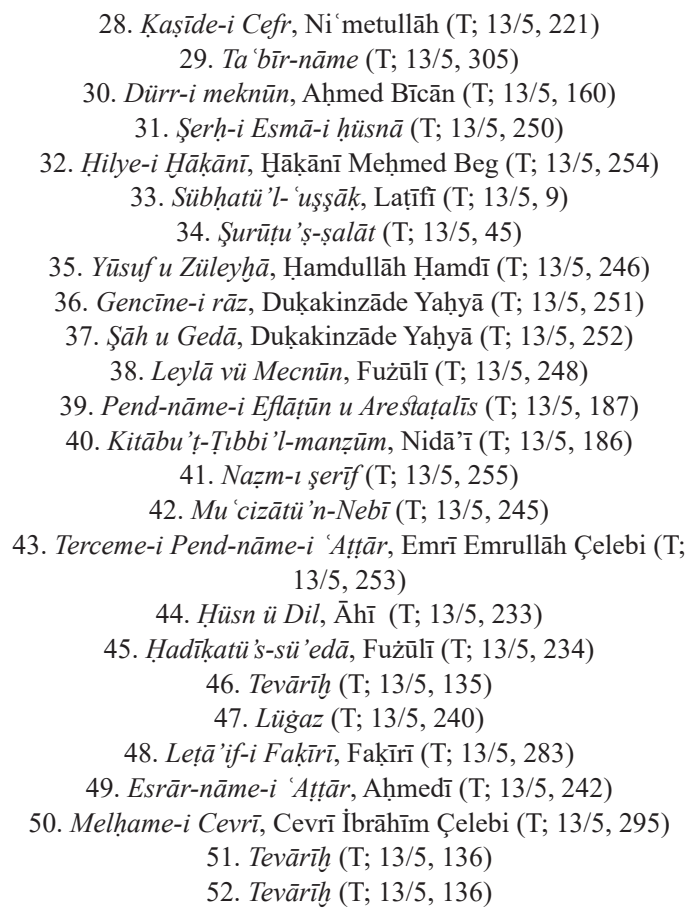 & Ms.or.quart. 1988 \\
\hline 1119. & 09.04 .1935 & Feth-nāme-i Sulțān Mehmed, Ḳıāmī (T; 13/1, 122) & Ms.or.quart. 1975 \\
\hline 1120. & 09.04 .1935 & Felāhat-nāme, Meḥmed b. Muștafā (T; 13/5, 291) & Ms.or.oct. 3664 \\
\hline 1121. & 09.04 .1935 & Fezzleke-i tārīh-i 'Oșmānī, 'Abdülbāḳī b. 'Alī (T; 13/1, 145) & Ms.or.quart. 1968 \\
\hline 1122. & 24.10 .1935 & Yūsuf u Züleyhāa, Yūsuf Cān (T; 13/2, 560) & Ms.or.oct. 3691 \\
\hline 1123. & 24.10 .1935 & 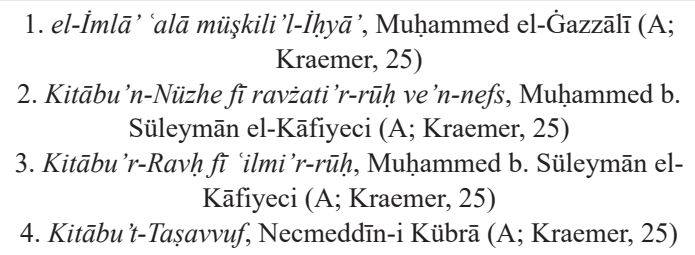 & Ms.or.fol. 4249 \\
\hline 1124. & 24.10 .1935 & Tārīh-i Nādirī (F-A-T; UC) & Ms.or.quart. 1992 \\
\hline 1125. & 24.10 .1935 & $\begin{array}{c}\text { Şerḥü Mukaddimeti Ebi'l-Leys es-Semerkandī, Muștafāa b. } \\
\text { Zekeriyā' el-Ḳaraman̄̄ (A; KOHD) }\end{array}$ & Ms.or.oct. 3693 \\
\hline 1126. & 24.10 .1935 & et-Tavi̇ịh, Muștafā b. Zekerīyā' el-Ḳaramanī (A; KOHD) & Ms.or.quart. 1993 \\
\hline
\end{tabular}


The Manuscripts Rescher Sold to the Berlin State Library (Reşer'in Berlin Devlet Kütüphanesi'ne Sattığı Yazmalar)

\begin{tabular}{|c|c|c|c|}
\hline Nr. & $\begin{array}{l}\text { Date } \\
\text { Tarih }\end{array}$ & $\begin{array}{c}\text { Name of Work, Name of Author (Language; Catalogue } \\
\text { Information) } \\
\text { Eser adı, Müellif adı (Dil; Katalog Bilgisi) }\end{array}$ & $\begin{array}{l}\text { Shelf nr. } \\
\text { Raf nr. }\end{array}$ \\
\hline 1127. & 24.10 .1935 & $\begin{array}{l}\text { 1. Risāle-i hey'et, 'Abdül 'alī b. Muhammed el-Bīrcendī (F; } \\
\text { KOHD) } \\
\text { 2. Coğrafya hakkında risale [Treatise on geography] (F; KOHD) } \\
\text { 3. } 12 \text { İmamın soyundan gelenlerin mezar yerleri hakkında } \\
\text { malûmat [Information about the burial places of the descendants } \\
\text { of the } 12 \text { Imams] (F; KOHD) }\end{array}$ & Ms.or.quart. 1995 \\
\hline 1128. & 24.10 .1935 & Tezkiretü'ş-şu'arā, Lațīî (T; 13/1, 263) & Ms.or.oct. 3701 \\
\hline 1129. & 24.10 .1935 & $\begin{array}{c}\text { el-Ahkāmü'l- 'Alā'iye fi'l-a'lāmi's-semā'iye, Fahreddīn er-Rāzī } \\
\text { (F; KOHD) }\end{array}$ & Ms.or.oct. 3704 \\
\hline 1130. & 24.10 .1935 & Envāru'l- 'āşıkīn, Aḥmed Bīcān (T; 13/2, 2) & Ms.or.oct. 3710 \\
\hline 1131. & 24.10 .1935 & et-Telhīṣ fi t'-Tefsīr, Aḥmed b. Yūsuf el-Kevāşī (A; KOHD) & Ms.or.quart. 1994 \\
\hline 1132. & 24.10 .1935 & Zübdetü'l-hakāāılk, 'Aynü'l-Ḳużāt el-Hemedānī (F-T-A; KOHD) & Ms.or.oct. 3692 \\
\hline 1133. & 24.10 .1935 & $\begin{array}{c}\text { el-Kitābu'l-Yemīnī, Muhammed b. 'Abdülcebbār el- 'Utbī (A; } \\
\text { KOHD) }\end{array}$ & Ms.or.oct. 3713 \\
\hline 1134. & 24.10 .1935 & Ma 'rifet-nāme, İbrāhīm Ḥaḳkī Erżurūmī (T; 13/2, 5) & Ms.or.oct. 3697 \\
\hline 1135. & 24.10 .1935 & $\begin{array}{c}\text { Nefehātü'l-üns min hạạāâti’l-ḳuds, 'Abdurrahmān Cāmī (F; } \\
\text { KOHD) }\end{array}$ & Ms.or.oct. 3727 \\
\hline 1136. & 24.10 .1935 & $\begin{array}{l}\text { 1. Şerhü'l-Mufașșal, 'Oșmān b. 'Ömer İbn el-Ḥācib (A; KOHD) } \\
\text { 2. Şerḥü Ebyāti'l-Mufașșal (A; KOHD) }\end{array}$ & Ms.or.oct. 3695 \\
\hline 1137. & 24.10 .1935 & Tahmīisü Kașīdeti'l-Bürde, İbn Kuṭbeddīn (A; KOHD) & Ms.or.quart. 1996 \\
\hline 1138. & 24.10 .1935 & Dīvān-ı Şāhī, Āḳā Melik b. Cemāleddīn (F; 16/1, 22) & Ms.or.oct. 3712 \\
\hline 1139. & 24.10 .1935 & Zeyl-i Tärīh-i Vạṣıf $(\mathrm{T} ; 13 / 1,199)$ & Ms.or.quart. 1997 \\
\hline 1140. & 24.10 .1935 & 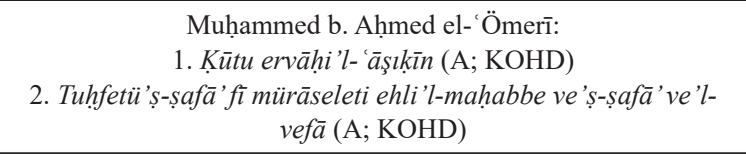 & Ms.or.oct. 3696 \\
\hline 1141. & 24.10 .1935 & Cāmasb-nāme, İsmā' īl b. Memiş (T; 13/2, 517) & Ms.or.oct. 3706 \\
\hline 1142. & 24.10 .1935 & Şühedā-i Kerbelā, Beḳā'ì (T; 13/3, 300) & Ms.or.quart. 1999 \\
\hline 1143. & 24.10 .1935 & et-Teysīr fi'l-ḳrā'àti's-seb 'a, Ebū 'Amr ed-Dānī (A; KOHD) & Ms.or.quart. 1998 \\
\hline 1144. & 24.10 .1935 & Nefise-i uhreviye, Kāmī Meḥmed-i Edirnevī (T; 13/4, 42) & Ms.or.oct. 3702 \\
\hline 1145. & 24.10 .1935 & $\begin{array}{c}\text { en-Nihāye fi şerhịi'l-Hidāye (el-cüz'ü'ś-s̄ālis [3 } 3^{\text {rd }} \text { vol.]), el-Ḥüseyn } \\
\text { b. 'Alī es-Signaḳi (A; KOHD) }\end{array}$ & Ms.or.quart. 2017 \\
\hline 1146. & 24.10 .1935 & Risāle-i Tașavvuf, Nūreddīn Enverī (T; 13/5, 89) & Ms.or.oct. 3703 \\
\hline 1147. & 24.10 .1935 & Niṣābü'l-iḥtisāb, 'Ömer b. Muḥammed es-Senāmī (A; KOHD) & Ms.or.oct. 3699 \\
\hline 1148. & 24.10 .1935 & $\begin{array}{c}\text { Kitābu Hāvi'l-esrāri'l-hafiye fi't-tevessül li-każā'i'l-hāāàt (A; } \\
\text { KOHD) }\end{array}$ & Ms.or.oct. 3700 \\
\hline 1149. & 31.01 .1936 & Muhibb ve maḥbūb, İhtiyār (F; KOHD) & Ms.or.oct. 3723 \\
\hline
\end{tabular}


The Manuscripts Rescher Sold to the Berlin State Library (Reşer'in Berlin Devlet Kütüphanesi'ne Sattığı Yazmalar)

\begin{tabular}{|c|c|c|c|}
\hline Nr. & $\begin{array}{l}\text { Date } \\
\text { Tarih }\end{array}$ & $\begin{array}{c}\text { Name of Work, Name of Author (Language; Catalogue } \\
\text { Information) } \\
\text { Eser adı, Müellif adı (Dil; Katalog Bilgisi) }\end{array}$ & $\begin{array}{l}\text { Shelf nr. } \\
\text { Raf nr. }\end{array}$ \\
\hline 1150. & 31.01 .1936 & $\begin{array}{l}\text { 1. Dìvān, 'Abdülbāḳī 'Ārif Efendi (T; 13/5, 216) } \\
\text { 2. Dīvān, Țālib (T; 13/5, 214) } \\
\text { 3. Hikāye-i Dervīş Halīl-i Kionevī, Sirrī İbrāhīm-i Üsküdārī (T; } \\
\text { 13/5, 256) }\end{array}$ & Ms.or.oct. 3717 \\
\hline 1151. & 31.01 .1936 & Ferhād-nāme, Şāhī (T; 13/2, 529) & Ms.or.quart. 2002 \\
\hline 1152. & 31.01 .1936 & $\begin{array}{l}\text { 'Abdürrezzāke el-Kāşşānī: } \\
\text { 1. Kitābu Hakāa'iki'l-Kur'ān (A; KOHD) } \\
\text { 2. el-Ișțlāḥāt (A; KOHD) }\end{array}$ & Ms.or.oct. 3719 \\
\hline 1153. & 31.01 .1936 & $\begin{array}{c}\text { er-Risāletü's-seyfiye fì ușūli'l-ahkāmi’ş-şer 'iye 'alā mežhebi’l- } \\
\text { Hanefiye, Muhammed b. 'Abdurrahịm aṣ-Șafì el-Hindī (A; } \\
\text { KOHD) }\end{array}$ & Ms.or.quart. 2008 \\
\hline 1154. & 31.01 .1936 & $\begin{array}{l}\text { Mīrek Muḥammed Naḳşbendī Taşkendī: } \\
\text { 1. Nevādirü'l-emșāl (F-T; KOHD) } \\
\text { 2. Şehrī vü gülì (T-F; KOHD) }\end{array}$ & Ms.or.oct. 3716 \\
\hline 1155. & 31.01 .1936 & $\begin{array}{c}\text { Tehżībü'l-esmā've'l-lugiāt (c. } 1 \text { [vol. 1]), Yahyā b. Şeref en- } \\
\text { Nevevī (A; KOHD) }\end{array}$ & Ms.or.quart. 2004 \\
\hline 1156. & 31.01 .1936 & 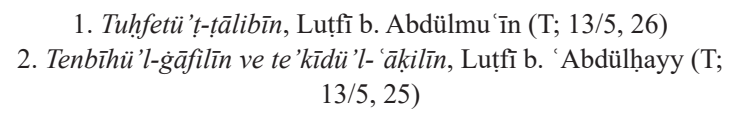 & Ms.or.quart. 2003 \\
\hline 1157. & 31.01 .1936 & Minhācu'l-İslām, 'Abdullāh b. İsmā'̄̄l (T; 13/4, 32) & Ms.or.quart. 2009 \\
\hline 1158. & 31.01 .1936 & $\begin{array}{c}\text { el-Mukaddimetü'l-Gazneviye fí fürū 'i’l-Hanefiye, Aḥmed b. } \\
\text { Muhammed el-Ġaznevī (A; KOHD) }\end{array}$ & Ms.or.quart. 2006 \\
\hline 1159. & 31.01 .1936 & $\begin{array}{l}\text { Tenbīhü'l-muġtarrīni evā'ili'l-karni'l- 'āşir 'alā mā hālefū fìhi } \\
\text { selefehümi't-țāhirīn, Ebu'l-Mevāhib 'Abdülvehhāb eş-Şa rānī } \\
\text { (A; 17B/1, 102) }\end{array}$ & Ms.or.oct. 3708 \\
\hline 1160. & 31.01 .1936 & $\begin{array}{c}\text { Hallü'r-rumūz ve keşfü mefātīhi'l-künūz, 'Abdüsselām b. Aḥmed } \\
\text { İbn Ġānim el-Maḳdisī (A; KOHD) }\end{array}$ & Ms.or.oct. 3720 \\
\hline 1161. & 31.01 .1936 & 1. Dìvān, Nābī (T; 13/2, 391) & Ms.or.quart. 2007 \\
\hline 1162. & 31.01 .1936 & Dīvān, Șā’ib-i Tebrīzī (F; KOHD) & Ms.or.oct. 3709 \\
\hline 1163. & 31.01 .1936 & Kitābu Lețā'ifi'l-fiker ve cevāmi 'i’d-dürer $(\mathrm{A} ; 17 \mathrm{~B} / 2,88)$ & Ms.or.oct. 3707 \\
\hline 1164. & 31.01 .1936 & $K u r^{\prime} \bar{a} n(\mathrm{~A} ; \mathrm{KOHD})$ & Ms.or.oct. 3711 \\
\hline 1165. & 31.01 .1936 & Strru'l-esrār, İbrāhīm b. Yūsuf el-Boluvī (T; 13/2, 217) & Ms.or.oct. 3721 \\
\hline 1166. & 31.01 .1936 & Mīzānü'l-hakk fì ihtiyāri'l-ehakk, Kātib Çelebi (T; 13/4, 138) & Ms.or.oct. 3718 \\
\hline 1167. & 31.01 .1936 & $\begin{array}{l}\text { 1. Kitābu'l-Erba'īn hadīsen, Yaḥyā b. Şeref en-Nevevī (A; } \\
\text { KOHD) } \\
\text { 2. Erba'ūne hadīsen (A; KOHD) } \\
\text { 3. Terceme-i Münferice (T; 13/5, 11) } \\
\text { 4. Ahsenü'l-ḥadīs , Okçıāde Meḥmed Şāhī (T; 13/5, 228) }\end{array}$ & Ms.or.oct. 3714 \\
\hline 1168. & 31.01 .1936 & $\begin{array}{l}\text { 1. } \bar{I}_{s} \bar{a} \dot{g} \bar{u} c \bar{l} f i \text { 'ilmi'l-manțı, Eșīreddīn el-Ebherī (A; KOHD) } \\
\text { 2. el-Fevā'idü'l-Fenāriye, Mollā Fenārī (A; KOHD) }\end{array}$ & Ms.or.oct. 3715 \\
\hline
\end{tabular}


The Manuscripts Rescher Sold to the Berlin State Library (Reşer'in Berlin Devlet Kütüphanesi'ne Sattığı Yazmalar)

\begin{tabular}{|c|c|c|c|}
\hline Nr. & $\begin{array}{l}\text { Date } \\
\text { Tarih }\end{array}$ & $\begin{array}{c}\text { Name of Work, Name of Author (Language; Catalogue } \\
\text { Information) } \\
\text { Eser adı, Müellif adı (Dil; Katalog Bilgisi) }\end{array}$ & $\begin{array}{l}\text { Shelf nr. } \\
\text { Raf nr. }\end{array}$ \\
\hline 1169. & 31.01 .1936 & $\begin{array}{l}\text { 1. Siyāset-i şer 'iye tercemesi, Meḥmed Sebzī (T; GDA) } \\
\text { 2. Münşe’āt (T; GDA) }\end{array}$ & Ms.or.oct. 3724 \\
\hline 1170. & 31.01 .1936 & Dīvān, Seyyid Vehbī (T; 13/2, 469) & Ms.or.quart. 2000 \\
\hline 1171. & 31.01 .1936 & $\begin{array}{c}\text { Tezkire bi-ahvōāli'l-mevtā ve umūru'l-āhire, Muhammed b. } \\
\text { Aḥmed el-Kurțubī (A; KOHD) }\end{array}$ & Ms.or.quart. 2015 \\
\hline 1172. & 31.01 .1936 & $\begin{array}{l}\text { el-Mīzānü'ş-Şa 'rāniyeti'l-müdhale bi-cemō'i akvāli'l-e'immeti'l- } \\
\text { müctehidīn ve mukallidihim fi'ş-şerī 'ati'l-Muhammediye, Ebu'l- } \\
\text { Mevāhib 'Abdülvehhāb eş-Şa rānī (A; KOHD) }\end{array}$ & Ms.or.quart. 2001 \\
\hline 1173. & 31.01 .1936 & 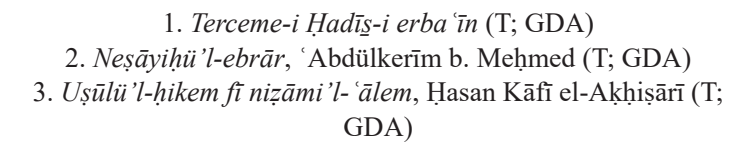 & Ms.or.oct. 3722 \\
\hline 1174. & 20.03 .1936 & $\begin{array}{l}\text { en-Nehrü'l-mādd mine'l-Baḥr, Ebū Ḥayyān el-Endelüsī (A; } \\
\text { KOHD) }\end{array}$ & Ms.or.quart. 2012 \\
\hline 1175. & 20.03 .1936 & 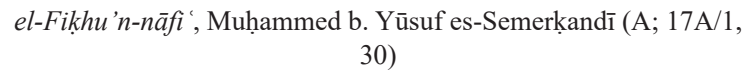 & Ms.or.oct. 3728 \\
\hline 1176. & 20.03.1936 & $\begin{array}{c}\text { el-Kevkebü'l-müşrik fimāa yahtāc ileyhi'l-müvesssık, Muhammed } \\
\text { b. 'Abdullāh el-Cerevānī (A; KOHD) }\end{array}$ & Ms.or.quart. 2011 \\
\hline 1177. & 20.03 .1936 & 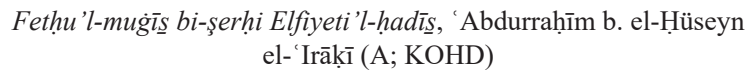 & Ms.or.quart. 2014 \\
\hline 1178. & 20.03.1936 & $\begin{array}{c}\text { Siletü's-simț ve simetü'l-mirț fì şerhi Simați'l-hedī fi'l-fahri'l- } \\
\text { Muhammedī (el-cüz'ü'l-evvel [1 } 1^{\text {st }} \text { vol.]), Muhammed b. 'Alī İbn } \\
\text { eş-Şabbāṭ (A; KOHD) }\end{array}$ & Ms.or.quart. 2016 \\
\hline 1179. & 20.03 .1936 & $\begin{array}{r}\text { ed-Dürretü'l-muḍ̂̀'a fì şerḥi'l-Elfiye, Muḥammed b. Muḥammed } \\
\text { İbn en-Nāẓim (A; KOHD) }\end{array}$ & Ms.or.quart. 2010 \\
\hline 1180. & 20.03 .1936 & $\begin{array}{c}\text { el-Käşiffì ma 'rifeti esmā'i'r-ricāl, Şemseddīn Ebū 'Abdullāh } \\
\text { ez-Zehebī }(\mathrm{A} ; 17 \mathrm{~B} / 1,508)\end{array}$ & Ms.or.oct. 3731 \\
\hline 1181. & 20.03 .1936 & İlahiler [Hymnody] (Ermenice [Armenian]; UC) & Ms.or.oct. 3725 \\
\hline 1182. & 18.06 .1936 & Muhtașar (F; UC) & Ms.or.oct. 3730 \\
\hline 1183. & 26.08 .1936 & Külliyāt-ı Şems-i Tebrīzī, Celāleddīn-i Rūmī (F; KOHD) & Ms.or.oct. 3738 \\
\hline 1184. & 26.08 .1936 & Yādigār-ı İbn Şerīf, İbn Şerīf (T; 13/5, 184) & Ms.or.quart. 2021 \\
\hline 1185. & 26.08 .1936 & $\begin{array}{c}\text { Biḍā'atü’l-mübted̄̄, 'Alī eț-Ṭabīb-i Bursevī (el-Münşī) (T; 13/4, } \\
416)\end{array}$ & Ms.or.oct. 3746 \\
\hline 1186. & 26.08 .1936 & $\begin{array}{c}\text { Kitābu Ma 'rifetü'l-hișāli'l-mükeffire li'z-żünūbi'l-mukaddime } \\
\text { ve'l-mu'ahhire, İbn Hacer el- 'Asḳalānī (A; KOHD) }\end{array}$ & Ms.or.oct. 3736 \\
\hline 1187. & 26.08 .1936 & $\begin{array}{c}\text { Muțtala 'u ḩușūṣi'l-kelim fì me 'ānī Füșūṣi 'l-ḥikem, Dāvūd-1 } \\
\text { Kayșerī (A; 17B/1, 93) }\end{array}$ & Ms.or.oct. 3737 \\
\hline
\end{tabular}


The Manuscripts Rescher Sold to the Berlin State Library (Reșer'in Berlin Devlet Kütüphanesi'ne Sattığı Yazmalar)

\begin{tabular}{|c|c|c|c|}
\hline Nr. & $\begin{array}{l}\text { Date } \\
\text { Tarih }\end{array}$ & $\begin{array}{l}\text { Name of Work, Name of Author (Language; Catalogue } \\
\text { Information) } \\
\text { Eser adı, Müellif adı (Dil; Katalog Bilgisi) }\end{array}$ & $\begin{array}{l}\text { Shelf nr. } \\
\text { Raf nr. }\end{array}$ \\
\hline 1188. & 26.08 .1936 & 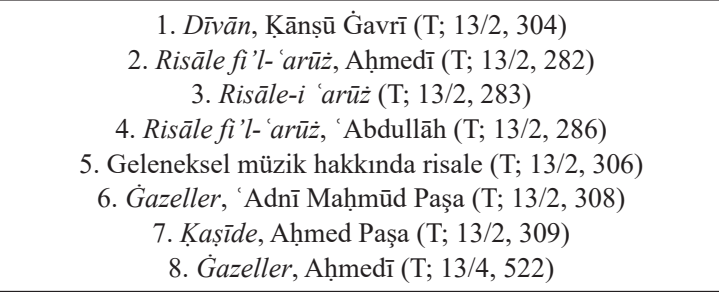 & Ms.or.oct. 3744 \\
\hline 1189. & 26.08 .1936 & $\begin{array}{c}\text { Kitābu Seyfǘl-kużāt 'ale’l-bugiāat, Muḥammed b. Süleymān el- } \\
\text { Kāfiyeci (A; KOHD) }\end{array}$ & Ms.or.oct. 3745 \\
\hline 1190. & 26.08 .1936 & Havāsī tașdīkāt, Hııżr b. Yūsuf (A; KOHD) & Ms.or.oct. 3743 \\
\hline 1191. & 26.08 .1936 & Mecmū a ez-şu 'arā-i mütekaddim (F; KOHD) & Ms.or.oct. 3735 \\
\hline 1192. & 26.08 .1936 & Местӣ' $a(\mathrm{~A} ; \mathrm{UC})$ & Ms.or.oct. 3742 \\
\hline
\end{tabular}

